UNIVERSIDADE DE SÃO PAULO

ESCOLA DE COMUNICAÇÃO E ARTES

PROGRAMA DE PÓS-GRADUAÇÃO EM CIÊNCIA DA INFORMAÇÃO

ADILSON SIQUEIRA DE ANDRADE

INFORMAÇÃO PARA POLÍTICAS PÚBLICAS DE DESENVOLVIMENTO EM RONDÔNIA

SÃO PAULO

2020 
ADILSON SIQUEIRA DE ANDRADE

\title{
INFORMAÇÃO PARA POLÍTICAS PÚBLICAS DE DESENVOLVIMENTO EM RONDÔNIA
}

\author{
Versão corrigida
}

Tese apresentada ao Programa de Pós-graduação em Ciência da Informação da Escola de Comunicação e Artes para obtenção do título de Doutor em Ciências da Informação.

Área de Concentração: Cultura e Informação

Linha de Pesquisa: Apropriação Social da Informação

Orientador: Prof. Dr. Marco Antônio de Almeida 
Autorizo a reprodução e divulgação total ou parcial deste trabalho, por qualquer meio convencional ou eletrônico, para fins de estudo e pesquisa, desde que citada a fonte.

Catalogaçäo na Publicaçäo

Serviço de Biblioteca e Documentaçäo

Escola de Comunicaçöes e Artes da Universidade de Säo Paulo Dados inseridos pelo(a) autor(a)

Andrade, Adilaon Siqueira de

INFORMAÇ̄o PARA POLITICAS PÚBLICAS DE DESENVOLVIMENTO EM

RONDÔNIA / Adilson Siqueira de Andrade; orientador, Narco Antonio de Almeida. - São Paulo, 2020.

139 p. : il.

Tean (Doutorado) - Programa de P6a-Graduação em Ciencia da Informaç̃̃o - Bacola de ComunicaçB̈ea e Artea / Univeraidade de Säo Paulo.

Bibliografia

Verabo corrigida

1. Apropriação social da informação 2. Desenvolvimento

Regional Sustentfivel 3. Obervat6rio de Desenvolvimento

Regional 4. Mediação da Informaç̃̃o 5. Politica PGiblica I.

Antenio de Almeida, Marco II. Título.

CDD 21.ed. - 020

Blaborado por Alemasndra Vieira Canholi Maldonado - CRB-8/6194 
ANDRADE, Adilson Siqueira. Informação para políticas públicas de desenvolvimento em Rondônia. 2020. 139 f. (Doutorado em Ciência da Informação) - Escola de Comunicação e Artes, Universidade de São Paulo, São Paulo, 2020.

Aprovado em 18 de dezembro de 2020

Banca Examinadora

Prof. Dr. Marco Antônio de Almeida - PPGCI - ECA/USP Presidente

Prof. Dr. José Carlos Vaz - EACH/USP

Prof $^{a}$. Dr ${ }^{\mathrm{a}}$. Giulia Crippa - PPGCI - ECA/USP

Prof. Dr. Renato Athias - CFCH/UFPE

Prof. Dr. Artur de Souza Morete - NCET/UNIR 


\section{AGRADECIMENTOS}

Agradeço em primeiro lugar a Deus por está no comando de tudo, sempre.

Agradece a Universidade Federal de Rondônia (UNIR) e a Universidade do Estado de São Paulo (USP) pelo acordo de cooperação pela realização do Doutorado Interinstitucional (DINTER) em Ciência da Informação.

Agradeço a Coordenação de Aperfeiçoamento de Pessoal de Nível Superior (CAPES) pelas bolsas no período de afastamento obrigado na USP/ São Paulo.

Agradeço meu orientador, Prof. Dr. Marco Antônio de Almeida, pela orientação, confiança e convivência, tanto presencial, quanto por "on line" nesse período de pandemia por conta do Covid-19, reuniões essas realizadas, tanto em Porto Velho, quanto em São Paulo, para definir as estratégias para a construção da tese.

Agradeço a Prof. ${ }^{a}$ Dr$^{a}$. Asa Fujino, coordenadora acadêmica do DINTER USP/UNIR, pela dedicação e carinho, sempre fornecendo orientação e proporcionando um espaço de convivência.

Agradeço a Prof ${ }^{a}$. Dra ${ }^{\mathrm{a}}$. Joliza Chagas Fernandes, coordenadora local do DINTER, amiga e companheira e incansável guerreira na defesa de uma educação pública e socialmente referenciada.

Agradeço à Prof ${ }^{a}$. Dra ${ }^{a}$. Giulia Crippa, pela convivência e aprendizado em sala de aula, bem como pela orientação na banca de qualificação.

Agradeço ao Prof. Dr. José Carlos Vaz, por ter participado da minha banca de qualificação, pela disponibilidade em sugerir referenciais que ajudaram na construção deste trabalho.

Agradeço aos professores: Marilda Lopes Ginez de Lara, Marcelo dos Santos, Marivalde Moacir Francelin, Nair Yumiko Kobashi, Rogério Mugnaini que nos acompanharam na trajetória desde a seleção para o ingresso no curso, bem como ministrando aulas em Porto Velho e bem como a amizade construída.

Agradeço ao Reitor Prof. Dr. Ari Miguel Teixeira Ott da UNIR que não mediu esforços para que o projeto do DINTER fosse efetivado, assim como toda equipe técnica da administração superior. (DACS)

Agradeço aos meus colegas do Departamento Acadêmico de Ciências Sociais

Agradeço o Prof. Dr. Artur de Souza Morete pelo apoio e sugestões na construção da tese.

Agradeço a Maira Miranda Ciorlin, secretária executiva da UNIR, pela revisão da língua portuguesa e a Suelen Reis Rodrigues pela transcrição das gravações.

Agradeço ao João Marcos Rodrigues Dutra, militante da coordenação nacional do Movimento dos Atingidos por Barragens (MAB) pelo apoio com relação os relatórios das barragens das Usinas Hidrelétricas do Rio Madeira e ao professor Vinícius Dantas Silveira e ao técnico administrativo Charles Dam da Silva, pela adaptação de mapas.

Agradeço os meus colegas do curso pela solidariedade e parceria; Adelmo Pedro de Oliveira Junior, Hugo Athanásios Fotopoulos, Israel Xavier Batista, Liliane Maria Nery Andrade, Marcos Leandro Freitas Hubner, Miguel Joaquim Sant'Anna Filho, Otacílio Moreira de Carvalho Costa, Pedro Ivo Silveira Andretta, Souza e Verônica Ribeiro da Silva Cordovil.

Agradeço aos servidores da Pós-graduação e da Biblioteca da ECA/USP, pelo apoio incansável.

Agradeço todos os interlocutores que me ajudaram com dados e informações fundamentais para a construção da tese: Avenilson Gomes da Trindade (SEAGRI), Camila Markeline da Silva (GDPP-SEPOG), Carlos Alberto Oliveira Costa (SEAGRI), Claudinei Lúcio Soares dos Santos (Tijolão) (MST-RO), Daniel Pereira - Ex-governador de Rondônia, 
e SEBRAE, Dom Roque Paloschi (CIMI), Hélio Dias de Souza (FAPERON) e presidente do SEBRAE-RO, Jorge Ugalde (GOB-SEPOG), Lázaro Aparecido Dobri (Lazinho da FETAGRO), Maria Petronila Neto (CPT), Marcelo Thomé da Silva de Almeida (FIERO), Natan Oliveira da Costa (SEPOG), Pedro Antônio Afonso Pimentel (SEPOG), Zilene Santana Silva Rabelo (GDPP-SEPOG).

Os meus agradecimentos ao jornalista e amigo Lenilson Guedes, Secretário da Superintendência Estadual de Comunicação do Governo de Rondônia (SECOM-RO) por abrir as portas a fim de que eu pudesse ser recebido pelos secretários e servidores das secretarias de estado.

Agradeço os meus filhos: Nádia Mariano Siqueira, Nadilson Mariano Siqueira, Railton Lima Siqueira de Andrade e Rafael Wanistin Siqueira de Andrade.

Agradeço a minha companheira Dilma Souza Costa pelo apoio carinhoso e sempre presente.

Agradeço aos meus pais: Arquimedes Machado Siqueira e Maria Siqueira de Andrade (Nádia) "in memoria".

Agradeço a Sociedade do Apostolado Católico (SAC) (padres e irmãos palatinos) da Província Nossa Senhora Conquistadora, com sede em Santa Maria-RS, como responsável por parte de minha formação acadêmica. 
ANDRADE, Adilson Siqueira. Informação para políticas públicas de desenvolvimento em

Rondônia. 2020. 139 f. (Doutorado em Ciência da Informação) - Escola de Comunicação e Artes, Universidade de São Paulo, São Paulo, 2020.

\section{RESUMO}

Este trabalho tem como tema "Informação para políticas públicas de desenvolvimento em Rondônia", e com o objetivo de investigar como o estado de Rondônia promove a mediação entre o governo e a sociedade civil, visando à construção de políticas públicas na perspectiva do desenvolvimento sustentável para a região. O estudo aborda o Observatório Estadual de Desenvolvimento Regional (ODR), como dispositivo de informação e comunicação, criado pelo governo do estado com base no Plano Estadual de Desenvolvimento Sustentável de Rondônia (PDES-RO). O Observatório é um repositório de informações responsável por avaliar e disponibilizar dados e análises de informações regionais, de forma a possibilitar a mediação entre o governo e a sociedade como um todo. Nesse sentido, questiona-se: como ocorre essa política de mediação entre governo e sociedade civil, na perspectiva do desenvolvimento regional sustentável, para o estado de Rondônia? Para viabilizar esta pesquisa, utilizou-se a seguinte metodologia: a) levantamento e revisão bibliográfica visando ao mapeamento do referencial teórico baseado em uma concepção dialética e em conceitos da Ciência da Informação (CI), considerando também as abordagens antropológicas do Desenvolvimento; b) realização de pesquisas documentais relacionadas ao governo de Rondônia, por meio de sites oficiais e de fontes como: relatórios, projetos em andamento; c) realização de entrevistas abertas e semi- estruturadas com dirigentes do governo, tanto da gestão anterior como atual, bem como com dirigentes da sociedade civil. Constatou-se que o Estado de Rondônia, mesmo definindo políticas de Desenvolvimento Sustentável, por meio do PDES-RO e de seu discurso, na prática incentiva o agronegócio e, por outro lado, não adota um procedimento de mediação com a sociedade civil através do ODR.

Palavras-chave: Apropriação social da informação. Desenvolvimento Regional Sustentável. Observatório de Desenvolvimento Regional. Mediação da Informação. Política Pública. 
ANDRADE, Adilson Siqueira. Information for public development policies in Rondônia. 2020. 139 f. (PhD in Information Science) - School of Communication and Arts, University of São Paulo, São Paulo, 2020.

\begin{abstract}
This paper has the theme "Information for public development policies in Rondônia", and with the objective of investigating how the state of Rondônia promotes mediation between the government and civil society, aiming at the construction of public policies in the perspective of sustainable development for the region. The study addresses the State Regional Development Observatory (ODR), as an information and communication device, created by the state government based on the Rondônia State Plan for Sustainable Development (PDES$\mathrm{RO})$. The Observatory is an information repository responsible for evaluating and providing data and analysis of regional information, in order to enable mediation between the government and society as a whole. In this sense, the question is: how does this policy of mediation between government and civil society, from the perspective of sustainable regional development, occur for the state of Rondônia? To make this research feasible, the following methodology was used: a) survey and bibliographic review aiming at mapping the theoretical framework based on a dialectical conception and concepts of Information Science (CI), also considering anthropological approaches to Development; b) conducting documentary research related to the government of Rondônia, through official websites and sources such as: reports, ongoing projects; c) conducting open and semi-structured interviews with government officials, both from previous and current management, as well as with civil society leaders. It was found that the State of Rondônia, even defining Sustainable Development policies, through the PDES-RO and its discourse, in practice encourages agribusiness and, on the other hand, does not adopt a mediation procedure with civil society through through the ODR.
\end{abstract}

Keywords: Social appropriation of information. Sustainable Regional Development. Regional Development Observatory. Information Mediation. Public policy. 


\section{LISTA DE SIGLAS}

ASSINCRA

ALE

CAPES

CATP

$\mathrm{CNDH}$

COP

CNUMAD

CEPLAC

CPT

BASA

BIRD

BID

BNB

BNDES

CIMI

EID

CI

CNA

CNDR

$\mathrm{CNDH}$

ECA

EMBRAER

EMBRAPA

E.F.M.M.

FAPERON

FECOMERCIO

FETAGRO

FIERO

GTA

IBGE

IDARON

IIRSA

INCRA

MI

MST

NUAR

ONG

OXFAM

$\mathrm{PCH}$

PDES

PNUD

PAA

BIB

PIC

PEDR

PIN

PLANAFLORO
Associação dos Servidores do INCRA

Assembleia Legislativa do Estado de Rondônia

Coordenação de Aperfeiçoamento de Pessoal de Nível superior

Alienação em Terras Públicas

Conselho Nacional dos Direitos Humanos

Conferência do Clima

Conferência das Nações Unidas sobre Meio Ambiente e

Desenvolvimento

Comissão Executiva do Plano da Lavoura Cacaueira

Comissão Pastoral da Terra

Banco da Amazônia

Banco Mundial

Banco Interamericano de Desenvolvimento

Banco do Nordeste do Brasil

Banco Nacional de Desenvolvimento Econômico e Social

Conselho Indigenista Missionário

Eixos de Integração e Desenvolvimento

Ciência da Informação

Confederação da Agricultura e Pecuária do Brasil

Conferência Nacional de Desenvolvimento Regional

Conselho Nacional de Direitos Humanos

Escola de Comunicação e Artes

Empresa Brasileira de Aeronáutica AS

Empresa Brasileira de Pesquisa Agropecuária

Estrada de Ferro Madeira Mamoré

Federação da Agricultura e Pecuária do Estado de Rondônia

Federação do Comércio do Estado de Rondônia

Federação dos Trabalhadores na Agricultura de Rondônia

Federação das Indústrias do Estado de Rondônia

Guia de Trânsito Animal

Instituto Brasileiro de Geografia e Estatística

Agência de Defesa Sanitária Agrosilvopastoril do Estado de

Rondônia

Integração da Infraestrutura Regional Sul-Americana

Instituto Nacional de Colonização e Reforma Agrária

Ministério da Integração Nacional

Movimento dos Trabalhadores Sem Terra

Núcleo Urbano de Apoio Rural

Organização Não Governamental

Oxford Famine

Pequena Central Hidrelétrica

Plano de Desenvolvimento Estadual Sustentável de Rondônia

Programa das Nações Unidas para o Desenvolvimento

Programa Estadual de Aquisição de Alimentos

Produto Interno Bruto

Projeto de Iniciativa Comunitária

Política Estadual de Desenvolvimento Regional

Programa de Integração Nacional

Plano Agropecuário e Florestal de Rondônia 
PIN

PNUD

PNDR

POLONOROESTE

RESEX

RI

SEAGRI

SEBRAE

SEDAM

SENAR

SEPOG

SUFRAMA

TIC

UC

UNIR

UHE

USP

UTE

VBP

WWF

ZFM

ZSEE-RO
Plano de Integração Nacional

Programa das Nações Unidas para o Desenvolvimento

Política Nacional de Desenvolvimento Regional

Programa de Desenvolvimento Integrado do Noroeste do Brasil

Reserva Extrativista

Reserva Indígena

Secretaria de Estado da Agricultura

Serviço Brasileiro de Apoio às Micro e Pequenas Empresas

Secretaria de Estado do Desenvolvimento Ambiental

Serviço Nacional de Aprendizagem Rural/RO

Secretaria de Estado do Planejamento, Orçamento e Gestão

Superintendência da zona franca de Manaus

Tecnologia de Informação e da Comunicação

Unidade de Conservação

Universidade Federal de Rondônia

Usina Hidrelétrica

Universidade de São Paulo

Usina Termelétrica

Valor Bruto da Produção

World Wide Fund for Nature

Zona França de Manaus

Zoneamento Socioeconômico-Ecológico do Estado de Rondônia 


\section{QUADROS}

Quadro 1- Produção de borracha natural (1856-1939) .........................................................51

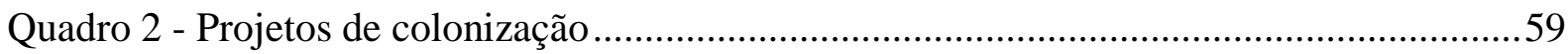

Quadro 3 - Divisão territorial da $1^{\mathrm{a}}$ Aproximação do Zoneamento Sócio-econômico-ecológico

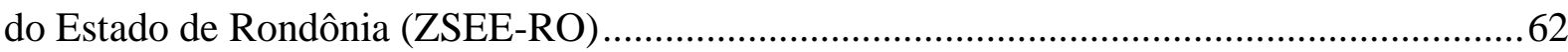

Quadro 4 - Resumo da Lei Complementar no 233 de 06 de junho de 2000 (2a Aproximação do

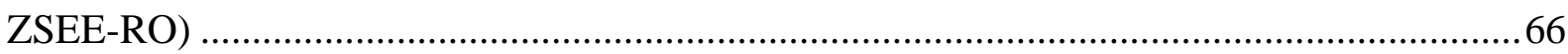

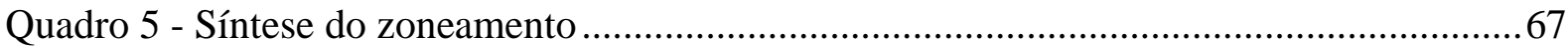

Quadro 6 - Regiões de Planejamento e Gestão para o Estado de Rondônia ............................75

Quadro 7 - Amazônia em conflito no campo 2015 a 2017 ...................................................... 101 


\section{FIGURAS}

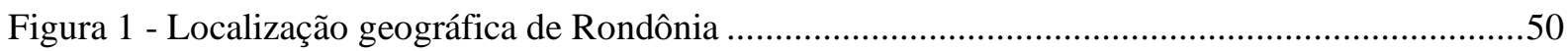

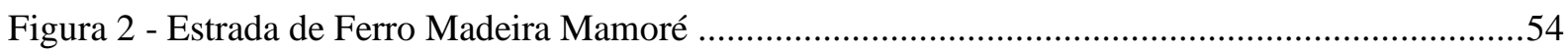

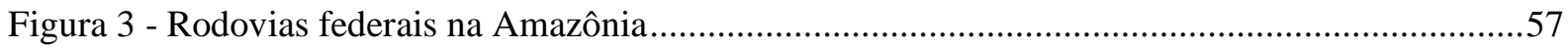

Figura 4 - $1^{\text {a }}$ Aproximação do Zoneamento Sócio-econômico-ecológico do Estado de Rondônia ........62

Figura 5 - 2ª Aproximação do Zoneamento Sócio-Econômico-Ecológico de Rondônia (ZSEE-RO)...66

Figura 6 - Mapa das Áreas Protegidas do Estado de Rondônia ............................................................68

Figura 7 - Terras Indígenas e Unidades de Conservação de Proteção Integral em Rondônia ...............69

Figura 8 - Eixo Integrado de Expansão na América do Sul ..............................................................72

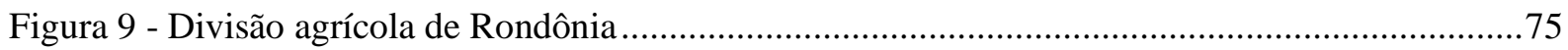

Figura 10 - Propriedades rurais existentes no estado de Rondônia .........................................................76

Figura 11 - Crescimento por demanda por alimento no planeta …….................................................79

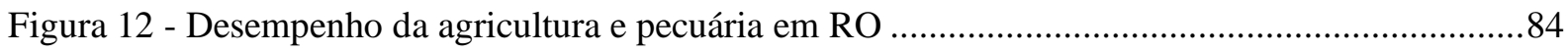

Figura 13 - Representação financeira do agronegócio em RO............................................................ 84

Figura 14 -Rebando de corte e leite em Rondônia (2019) ...................................................................95

Figura 15 - Produção de soja em Rondônia …………......................................................................96

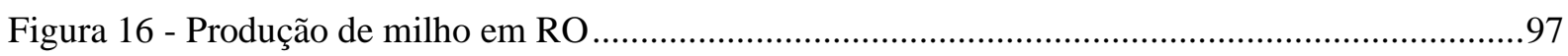

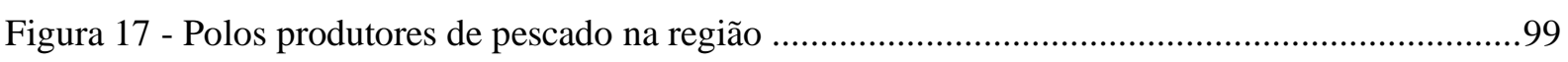

Figura 18 - Produção de peixe nativo em cativeiro ........................................................................ 100

Figura 19 - Portal do Observatório de Desenvolvimento Regional (ODR) ........................................111 


\section{SUMÁRIO}

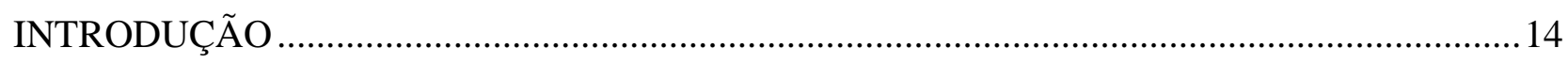

1 INFORMAÇÃO PARA DECISÃO E PARA AÇÃO POLÍTICA ........................................20

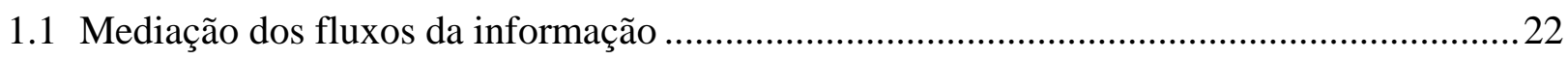

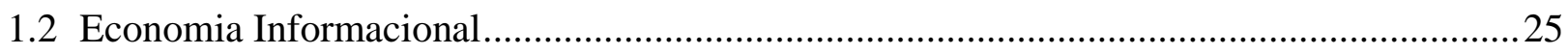

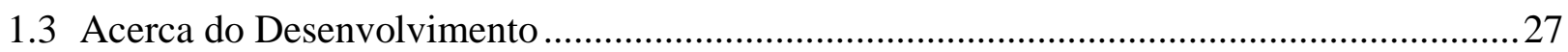

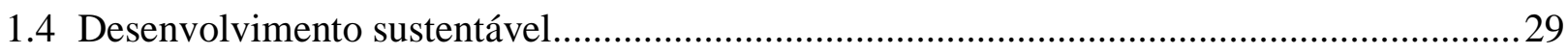

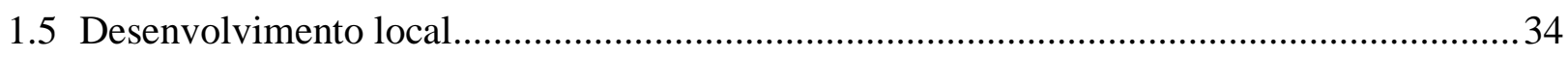

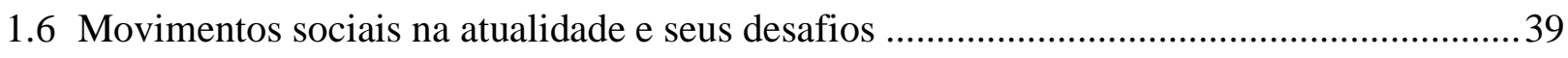

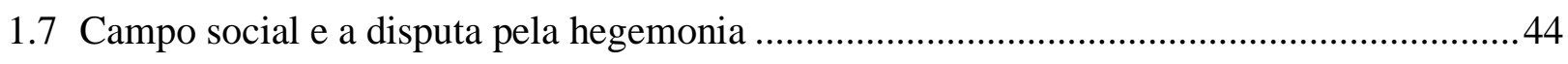

2 RONDÔNIA NO CONTEXTO REGIONAL .................................................................

2.1 A borracha como ouro branco da Amazônia ...................................................................50

2.2 Estrada de Ferro Madeira Mamoré .................................................................................53

2.3 Rondônia um Território de Experimentos ...................................................................55

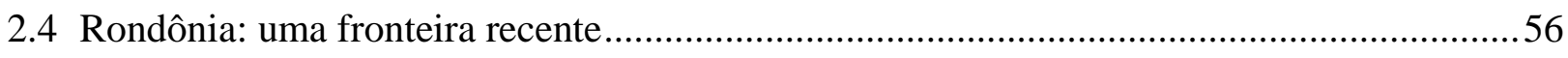

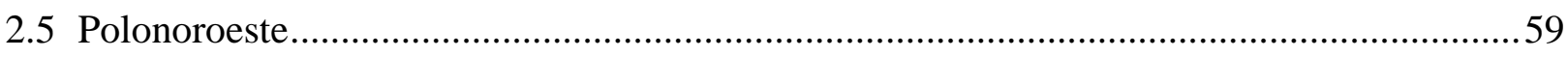

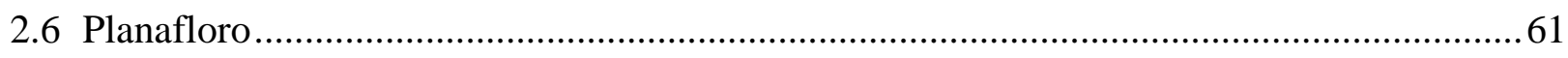

2.6.1 $1^{\mathrm{a}}$ Aproximação do Zoneamento Socioeconômico e Ecológico .................................61

2.6.2 2a Aproximação do Zoneamento Socioeconômico e Ecológico .................................64

2.6.3 Atualização da $2^{\mathrm{a}}$ aproximação do ZSEE-RO ......................................................69

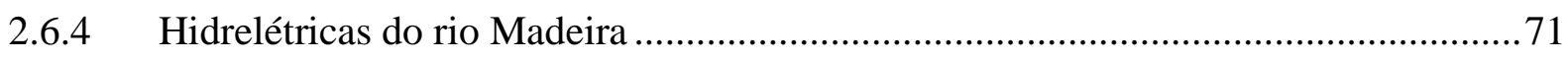

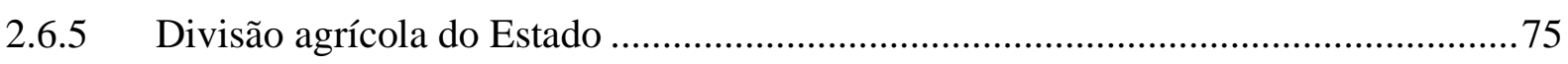

3 DESENVOLVIMENTO REGIONAL E O ODR COMO MECANISMOS DE MEDIAÇÃO

3.1 O governo e o desenvolvimento regional ................................................................ 81

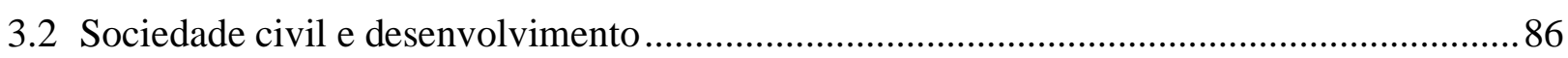

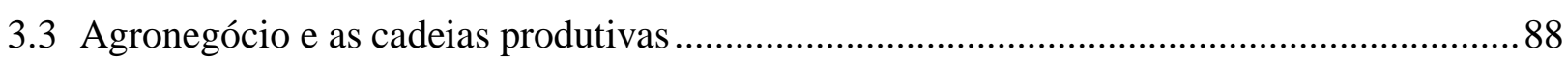

3.4 Questões indígenas e os impactos ambientais ............................................................... 104

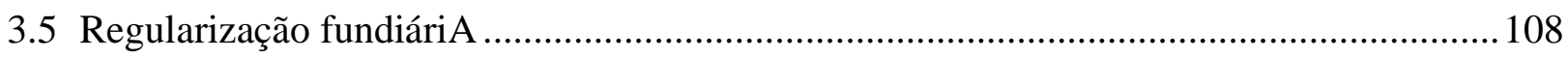

3.6 ODR e o espaço de mediação na perspectiva dos atores ................................................. 111

3.7 A ODR como instância de mediações ........................................................................... 115

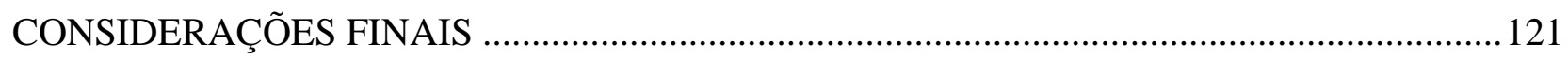

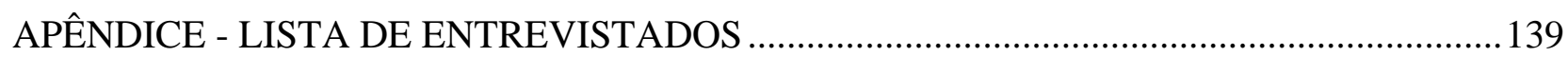




\section{INTRODUÇÃO}

No limiar do século XXI observa-se que o crescimento sistematizado da globalização, bem como da concentração de renda, tem provocado desigualdades sociais. O modelo capitalista neoliberal ao mesmo tempo em que gera riquezas para alguns países e grupos econômicos aumenta a pobreza para os já excluídos da sociedade. As Tecnologias da Informação e Comunicação (TICs) provocam mudanças no comportamento das pessoas e das culturas, contudo muitos povos continuam isolados não somente da informação, mas do acesso aos bens e serviços.

Nesse contexto, Queiroz e Noronha (2004) destacam que a ciência é um processo social que tem como funções primordiais disseminar informações, assegurar a preservação de padrões e atribuir crédito e reconhecimento acadêmico cujas descobertas científicas têm contribuído para o desenvolvimento humano. Assim os novos conhecimentos produzidos devem chegar ao domínio e utilização por todas as sociedades.

As políticas neoliberais adotadas por vários países, incluindo o Brasil, têm assumido posicionamento de privatização em detrimento de ações sociais voltadas à sociedade, tais como: educação, saúde, habitação, saneamento básico, acesso à alimento e terra para as comunidades rurais, entre outras. Esse modelo não tem sido capaz de promover justiça social, ao contrário, tem privilegiado às classes sociais mais abastadas, agravando ainda mais a exclusão social.

Com o avanço das novas TICs acentuam-se as mudanças nas formas de organizações, tanto do mercado, quanto da relação do trabalho humano. A sociedade civil vem procurando se ajustar a essas mudanças na perspectiva de encontrar novas formas de organizações e de lutas no campo da disputa pela hegemonia política.

A concepção de desenvolvimento socioeconômico se constituiu como um marco referencial para as sociedades na contemporaneidade. Governos e organizações multilaterais têm promovido debates visando encontrar formas de convivência entre os seres humanos com os demais seres que formam o ecossistema. Nessa perspectiva, várias iniciativas vêm acontecendo como a reunião de Estocolmo, na Suécia, a Eco-92 (ou Rio 92), o encontro de Paris, a Rio +20 , que são algumas manifestações de governos e da sociedade civil que se afirmam em favor de uma ética planetária sustentável.

A repercussão dessas manifestações influencia governos em nível internacional e nacional, e, no caso brasileiro, tem repercutido no debate sobre sustentabilidade e na busca de planejamento de políticas públicas e de governança que possam levar em conta a concepção 
de desenvolvimento sustentável. A compreensão desse debate tem considerado o planejamento de uma economia que busque a superação das desigualdades regionais/locais, das populações que vivem nas cidades e das que vivem no campo. Nesse contexto, chama a atenção que os governos debatem o assunto da sustentabilidade, mas buscam adotar políticas que visam à exportação de commodities em detrimento da produção de alimentos destinados ao atendimento regional. Com esse olhar é que se percebe a ocupação da Amazônia com vistas ao agronegócio.

A Amazônia se situa em um amplo território brasileiro. Compõem a Amazônia Legal 09 (nove) estados, sendo eles: Acre, Amapá, Amazonas, Mato Grosso, Pará, Roraima, Tocantins, parte do Maranhão e Rondônia.

A ocupação na Amazônia tem se dado de forma sistematizada e para compreender esse processo, deve-se observar os chamados ciclos econômicos da região, tais como: borracha, madeira, mineração e, mais recente, o ciclo do agronegócio. Com a queda da produção da borracha, e visando incentivar a região, o governo de Juscelino Kubitschek criou a Zona Franca de Manaus (ZFM), porém ela só foi implantada no governo militar, em 1967. A ZFM compõe três eixos: o comercial, o industrial e o agropecuário.

Outro programa governamental que deve ser levado em conta é o Programa de Integração Nacional (PIN), em 1970 também no governo militar, que tinha como finalidade a criação de infraestrutura socioeconômica para as regiões norte e nordeste do Brasil. Como objetivo principal e visando à integração da região, principalmente por nordestinos, se fazia necessário abrir rodovias, portos, efetivar programas de colonização e incentivar a implantação de projetos agropecuários e agroindustriais na região.

A ocupação em Rondônia se configura na mesma filosofia do PIN, sendo que a migração acelerada se processou nas décadas de 1970 e 1980. Dois grandes projetos devem ser levados em consideração: o Programa de Desenvolvimento Integrado para o Noroeste do Brasil (POLONOROESTE), criado em 1981, teve como objetivo principal a criação de infraestrutura no estado de Rondônia, dando suporte aos migrantes que foram estimulados para se deslocarem para esta região, bem como consolidar através de pavimentação asfáltica a BR 364; e o Plano Agropecuário e Florestal de Rondônia (PLANAFLORO), criado na década de 1990, que teve como objetivo avaliar todas as atividades referentes ao desenvolvimento sustentável das populações originárias (indígenas) e tradicionais (seringueiros, pescadores artesanais e pequenos proprietários rurais), levando em conta a saúde, educação, água potável. Esse projeto resultou da lei de zoneamento sócio-econômico-ecológico de Rondônia. 
Já recentemente, o governo de Rondônia, com apoio do governo federal, criou o Plano de Desenvolvimento Estadual Sustentável de Rondônia (PDES-RO), objetivando a implantação de políticas públicas com a concepção de desenvolvimento sustentável no período de 2015 a 2030. No âmbito desse plano, foi criado o Observatório de Desenvolvimento Regional $\left(\mathrm{ODR}^{1}\right.$ ) como sendo “[...] uma Multiplataforma Georreferenciada destinada a receber, relacionar, organizar e distribuir dados geográficos e literais em ambiente único de modo a possibilitar a pesquisa e recuperação de informações e edição de dados" (RONDÔNIA, 2018), além de ser um dispositivo de armazenamento e de informação das políticas governamentais que visa promoção e o monitoramento das ações políticas do governo e um instrumento de mediação com a sociedade civil. Nessa perspectiva, a sociedade, ao ter acesso, tem a possibilidade de intervir objetivando a construção de políticas públicas de desenvolvimento sustentável local.

Nesse contexto é que se situa o objetivo deste trabalho, que é de investigar como o governo de Rondônia realiza a mediação, eficaz e eficiente ${ }^{2}$, com a sociedade civil, visando à construção de políticas públicas na perspectiva do desenvolvimento sustentável para a região, levando em conta os estudos e dados armazenados no ODR e o diálogo com a sociedade civil. Assim, levanta-se o problema científico: nas instâncias de planejamento governamental há conhecimentos produzidos e articulados, entretanto, as informações não saem do âmbito governamental. Nesse sentido, se indaga: de que forma ocorre a política de mediação entre governo e sociedade civil? Os conhecimentos produzidos têm servido para a formulação e implantação de políticas públicas na concepção do desenvolvimento regional sustentável para o estado de Rondônia?

Visando responder a indagação, levanta-se a seguinte hipótese de trabalho: o governo do estado de Rondônia, ao elaborar o PDES-RO, cumpre um papel burocrático na política interna, ou seja, busca se adequar às orientações do governo federal, mantém o discurso do desenvolvimento sustentável, mas na prática estimula ações na perspectiva de se implantar

\footnotetext{
${ }^{1}$ Observatório Estadual de Desenvolvimento Regional (ODR), além de ser uma multiplataforma georeferenciada, tem os seguintes objetivos: a) apoiar o Governo Estadual, e demais Órgãos da Administração Pública do estado, na Política Estadual de Desenvolvimento Regional, possibilitando a elegibilidade, monitoramento e avaliação das políticas e programas implementados; b) possibilitar que as informações organizadas no Observatório sirvam como canal de comunicação entre os diversos órgãos estaduais e demais órgãos da sociedade, assim como para a ação e coordenação de iniciativas várias através de políticas e programas pactuados nas regiões; c) possibilitar ao cidadão e à sociedade civil organizada formas de exercer o controle social e a participação de forma conjunta nas ações de governo; d) garantir os resultados das políticas de coesão econômica e social, priorizando ao mesmo tempo a disseminação cognitiva de informações, e, e) servir de fonte de informação para diferentes atores e instituições que acompanham, produzem e atuam em ações que objetivam a diminuição das disparidades regionais. (RONDÔNIA, 2018).

${ }^{2}$ Eficaz (ou eficácia) refere-se a fazer o que deve ser feito. Este conceito tem a ver com o foco em uma determinada direção (visão) e concentração de energia (recursos humanos, materiais e financeiros) para a execução da missão. Eficiente (ou eficiência) refere-se a como fazer o que tem para ser feito.
} 
políticas voltadas ao agronegócio como carro chefe da produção agrária. Por outro lado, podese afirmar provisoriamente que não há interesse político do governo do estado em disponibilizar informações por meio do Observatório de Estadual de Desenvolvimento Regional (ODR), esvaziando o órgão e dessa forma dificultando o exercício da mediação entre o governo e a sociedade civil, que deveria ser sua função.

O presente trabalho de pesquisa se justifica visto que pela primeira vez será estudada a relação do governo de Rondônia com a população, a partir da leitura sócio-antropológica, sobre o desenvolvimento regional com o enfoque da Ciência da Informação (CI) na perspectiva da mediação da informação, o que o torna um trabalho com viés diferenciado em relação à área, podendo, dessa forma, auxiliar em outros trabalhos acadêmicos bem como contribuir no conhecimento das ações do governo quanto à implementação das políticas públicas.

Outro fator de interesse pessoal deste pesquisador constitui-se no prosseguimento da temática de minha dissertação de mestrado, cujo enfoque foi "ONGs e Desenvolvimento Regional em Rondônia”.

A metodologia da pesquisa tem como base o levantamento de informações por meio de relatórios e sites institucionais do governo de Rondônia, colhendo depoimentos diretos por meio de entrevista semiestruturada, tanto com membros da atual gestão do governo (20192022) quanto com membros da gestão passada (2015-2018) que hoje desenvolvem atividade em outros setores e, ainda, com lideranças da sociedade civil, participação em eventos promovidos pelo governo tais como feira de negócios, reunião do Conselho de Desenvolvimento Ambiental e reunião com membros do governo e da sociedade civil.

As informações foram colhidas com a diretoria das seguintes instituições: Secretaria de Estado de Planejamento, Orçamento e Gestão (SEPOG); Secretaria de Estado da Agricultura (SEAGRI); Secretaria de Estado do Desenvolvimento Ambiental (SEDAM); Federação das Indústrias do Estado de Rondônia (FIERO); Federação da Agricultura e Pecuária do Estado de Rondônia de Rondônia (FAPERON); Federação dos Trabalhadores na Agricultura de Rondônia (FETAGRO); Serviço Brasileiro de Apoio às Micro e Pequenas Empresas (SEBRAE-RO); Conselho Indigenista Missionário (CIMI); Movimento dos Trabalhadores Rurais Sem Terra de Rondônia (MST-RO); e Comissão Pastoral da Terra (CPT). Os entrevistados serão descritos nominalmente e tratados como interlocutores no texto.

Nesse sentido, será considerada a visão de Geertz (1978, p.15) que destaca que para se compreender uma cultura diferente é necessário "[...] estabelecer relações, selecionar 
informante, transcrever textos, levantar genealogias, mapear campo, manter um diário, e assim por diante". Assim, deve-se trabalhar na perspectiva de uma visão semiótica a fim de decifrar os códigos ou signos inseridos na sociedade pesquisada: “[...] o homem é um animal amarrado a teias de significados que ele mesmo teceu, assumo a cultura como sendo essas teias e a sua análise; portanto, não como uma ciência experimental em busca de leis, mas como uma ciência interpretativa, à procura do significado" (GEERTZ, 1978, p.15).

Outro autor a ser utilizado como referencial na pesquisa de campo é Cardoso de Oliveira (2006) que diz que o pesquisador, no campo, deve adotar as seguintes abordagens: saber ver e saber ouvir para poder escrever.

O foco da pesquisa dialogou com a Ciência da Informação (CI) buscando compreender as mudanças culturais proporcionadas pelas novas tecnologias, além de se realizar uma abordagem antropológica sobre desenvolvimento sustentável local, bem como compreender a disputa da sociedade civil no campo do capital social, considerando os distintos fluxos de informação e suas origens.

A construção teórica está contida no primeiro capítulo do trabalho e se fará uma abordagem acerca da Ciência da Informação (CI), as mudanças culturais promovidas através das novas Tecnologias da Informação e da Comunicação (TICs) e como se processa a mediação na atual globalização. Com as novas TICs, verificam-se as mudanças tanto na economia quanto nas relações de trabalho, bem como na forma organizativa da sociedade civil para intervir na disputa dos campos político e social.

Um dos pontos centrais do trabalho refere-se às concepções teóricas sobre o desenvolvimento sustentável e assim, possibilitará a compreensão da adoção de procedimentos sobre políticas públicas com vistas à implantação do PDES-RO, bem como da governabilidade adotada no estado, levando em conta ainda a relação com a sociedade civil.

No segundo capítulo será feita abordagem sobre ocupação do território de Rondônia, abrangendo os ciclos econômicos da borracha, como já mencionado, e nesse contexto, a construção da Estrada de Ferro Madeira Mamoré (E.F.M.M.), além de destacar que a região serviu com um laboratório experimental dos grandes projetos de ocupação humana na Amazônia, tais como a expansão migratória a partir da década de 1960, projetos como POLONOROESTE (1980) e PLANAFLORO (1990/2000) que estabeleceu o zoneamento socioeconômico-ecológico, e a construção das hidrelétricas do rio Madeira - Jirau e Santo Antônio (2012), seguindo o projeto "Iniciativa para a Integração da Infraestrutura Regional Sul-Americana" (IIRSA). Por outro lado, observa-se o avanço do agronegócio na região, 
principalmente a pecuária e a soja, gerando o impacto nas pequenas propriedades e nas comunidades originárias e tradicionais.

Além disso, verifica-se que o governo federal, após a Conferência Rio/92, adotou o discurso da descentralização administrativa para se implantar o desenvolvimento sustentável, visando à diminuição das desigualdades regionais no Brasil. Assim, o estado de Rondônia, criado em 1981, hoje com 52 (cinquenta e dois) municípios e dividido em 10 (dez) regiões administrativas, reúne muitas dificuldades referentes à falta de infraestrutura, tanto urbana, quanto rural, carecendo de grandes investimentos. Observa-se que a arrecadação do estado é insuficiente para atender toda a demanda reprimida, sendo possível afirmar que se o governo federal não der suporte financeiro não será implantado o projeto PDES-RO.

Em contrapartida, destaca-se que Rondônia foi o primeiro estado da Federação a aprovar a Lei do Zoneamento Socioeconômico Ecológico de Rondônia (ZSEE-RO), com demarcação de Unidades de Conservações (UC) e Reservas Indígenas (RI), sem, contudo deixar de registrar a existência de conflitos agrários, envolvendo comunidades originárias (indígenas) e tradicionais (ribeirinhos extrativistas e quilombolas).

No terceiro e último capítulo, há a contextualização e análise do campo da pesquisa, elaborando abordagem sobre a concepção de desenvolvimento e as formas que o governo vem adotando sistema de governança para atender o disposto no Plano Estadual de Desenvolvimento de Rondônia (PDES-RO) e se verificará se o governo vem dando atenção para efetivação do ODR enquanto dispositivo de informação e mediação. Será dada ênfase não somente aos gestores do governo, mas de forma proporcional às lideranças da sociedade civil, previamente elencadas, visando analisar o grau da participação quanto à formulação de políticas públicas na perspectiva da implantação da concepção do desenvolvimento sustentável.

Encerrando a tese, teremos as considerações finais, compilando e resumindo os principais tópicos desenvolvidos durante a trajetória do texto, confrontando-os com a hipótese inicial e elaborando as conclusões devidas. 


\section{INFORMAÇÃO PARA DECISÃO E PARA AÇÃO POLÍTICA}

Neste capítulo será destacada a importância da informação para o planejamento e decisão política, particularmente no âmbito da Ciência da Informação (CI) em uma abordagem sociocultural e econômica, levando em conta a perspectiva histórica e, consequentemente, as mudanças de paradigmas decorrentes das novas formas de ação política na globalização. O capítulo se estrutura por meio de um conjunto de tópicos que sistematizam as principais discussões e conceitos que permeiam essa temática e que servirão como referenciais para a discussão posterior acerca do papel do Observatório de Desenvolvimento de Rondônia (ODR).

É necessário destacar que a Ciência da Informação (CI) se constitui como disciplina multidisciplinar e se consolida após a segunda guerra mundial. Nessa perspectiva, Seracevic (1996, p.42) ao abordar sobre a origem da CI afirma:

Como muitos outros campos interdisciplinares (como ciência da computação, pesquisa operacional) e CI tiveram sua origem no bojo da revolução científica e técnica que se seguiu à Segunda Guerra Mundial. Esse processo de emergência de novos campos ou de refinamento/substituição de conexões interdisciplinares dos campos antigos, de forma alguma está terminando, como testemunha a emergência, na última década ou pouco mais, da ciência cognitiva. Portanto, a CI está seguindo os mesmos passos evolutivos de muitos outros campos.

Com o avanço das novas Tecnologias da Informação e da Comunicação (TICs) criaram-se desafios para a Ciência da Informação (CI). "O advento dos computadores e da internet propiciou um acesso extremamente amplo a todo tipo de documentos e registros de conhecimento, do passado e do presente, de todos os lugares do mundo, em tempo real, a partir de diversos dispositivos, inclusive móveis" (ARAUJO, 2018, p.48), porém deve-se observar que nem toda população do planeta tem acesso à essas novas tecnologias, o que limita o acesso à informação.

Por outro lado, não se pode olvidar que em todas as etapas da história da humanidade existiram formas de armazenamento e compartilhamento das informações e do conhecimento, ou seja, sempre houve mediação informacional. Capurro (2017, p.6), ao tratar dos paradigmas epistemológicos da ciência da informação, diz: "A ciência da informação tem, por assim, dizer, duas raízes; uma é biblioteconomia clássica ou, em termos mais gerais, o estudo dos problemas relacionados com a transmissão de mensagens, sendo a outra a computação digital". Na mesma toada, Miranda e Ribeiro (2018, p.48) ao comentarem sobre a origem da 
CI, destacam Paul Otlet, principalmente no que se refere às duas grandes obras Traité de documentation, em 1934 e Monde: Essai d'universalisme, em 1935:

\begin{abstract}
Os estudos de Otlet funcionaram como ponto de partida para a consolidação da Documentação e da sedimentação da Biblioteconomia, da Arquivologia, da Ciência da Informação e da Museologia. Seus manuscritos apresentam o reconhecimento de sua efetiva contribuição para os estudos precursores da Web. Otlet teve a visão de uma grande rede de conhecimento centrado em documentos e na inclusão das noções de hipertextualidade, dos motores de busca, do acesso remoto, e das redes sociais, o que demonstra sua visão de futuro e o seu pioneirismo.
\end{abstract}

A análise dos autores se situa na perspectiva de um paradigma físico, relacionando ao armazenamento da informação, conforme já mencionado. Nesse contexto, deve-se considerar que no século XIX e início do século XX predominaram os pensamentos evolucionistas e positivistas, que influenciaram em todas as áreas do conhecimento, contudo as abordagens no campo epistemológico foram mudando já a partir do primeiro quarto do século XX; do ponto de vista das ciências sociais as abordagens passam a ser compreendidas com uma visão funcionalista, estruturalista e cognitiva.

Para Araújo (2009, p.194) “A informação é definida como uma medida de incerteza não como aquilo que é informado, mas como aquilo que se poderia informar". Nesse contexto a informação é vista como probabilidade e, segundo o autor, essa visão surge na década de 1930. Além disso, o autor destaca que no âmbito da CI, a teoria sistêmica se relaciona com a teoria funcionalista, que compreende a existência da comunicação em todas as sociedades. Também se evidencia a teoria crítica como uma atitude epistemológica que remonta a dialética de Heráclito e Hegel, com uma concepção marxista.

Nessa abordagem, vários autores tratam a informação pela ideia de materialidade, ou seja, está relacionada ao campo institucional, tecnológico, político, econômico e cultural. Assim, pode se afirmar que a CI teve sua origem no contexto da revolução científica e técnica no pós-segunda guerra mundial e sua estruturação tem se dado em diversos países, seguindo pressupostos distintos, não como uma ciência de um único país, mas acompanhando o processo globalizante. (ALMEIDA, 2007; 2014; SERACEVIC, 1996; ARAÚJO, 2018; ALBAGLI e MACIEL, 2004; LARA, FUJINO e NORONHA, 2007).

Seracevic (1996, p.60), ao analisar a CI, aponta:

Nas últimas quatro décadas a CI apresentou contribuições que influenciaram o modo como à informação é manipulada na sociedade e pela tecnologia e também permitiu melhor compreensão para um rol de problemas, processos 
e estruturas associados ao conhecimento, à informação e ao comportamento humano frente à informação.

A Ciência da Informação (CI), assim com as demais ciências, deve ser analisada dentro de uma abordagem histórica.

\subsection{MEDIAÇÃO DOS FLUXOS DA INFORMAÇÃO}

Como se pode denotar, a CI está intrinsecamente relacionada com as Tecnologias da Informação e Comunicação (TICs). Almeida e Crippa (2009, p.123), ao analisarem essa questão, destacam:

As novas tecnologias impõem uma reorganização da informação não mais ligada à estrutura física de bibliotecas tradicionais e arquivos: a área de informação é responsável pela preservação, distribuição e acesso à informação, tanto para públicos especializados como para a população em geral. Todavia, isso não se realiza através de princípios de ordem aleatórios, mas sim relacionados com as instituições e empresas interessadas na produção e disseminação da própria informação.

Os autores evidenciam que as TICs, além de induzirem aos usuários da informação os novos saberes para um efetivo uso das novas ferramentas, também obrigam os profissionais que trabalham na área a estabelecerem novos redimensionamentos na concepção e abordagens dos fatos. Acrescentam, ainda, sobre as TICs: “[...] a tecnologia é mais que um conjunto de técnicas, trata-se de todo um sistema de relações sociais, com amplas repercussões na constituição da própria sociedade. [...] A tecnologia modifica/redimensiona nossa visão de mundo" (ALMEIDA; CRIPPA; 2009 p.124). Dessa forma, o que se observa, é que com as novas ferramentas tecnológicas, a sociedade vem modificando as suas formas de conceber a realidade.

Sobre o campo da CI, Almeida e Crippa (2009, p.125) fazem uma abordagem do papel do cientista da informação como mediador e destacam:

[...] o cientista da informação está empenhado na construção de ferramentas classificatórias no horizonte dos novos suportes tecnológicos, tornando-se, nesse sentido, mediador para os usuários, desenhando, através das ferramentas, a configuração do que seu tempo e sua sociedade definem como ciência [...] Como mediador, o cientista da informação poderia, portanto, contribuir para a ampliação e melhoria desse diálogo.

Nessa perspectiva, o cientista da informação deve estar conectado com as novas mídias a fim de estabelecer leituras apropriadas da realidade, pois com o uso das TICs, os usuários da informação passam a ser atores do quadro que se apresentam, ou seja, passam a interagir com as novas linguagens midiáticas. 
Deve-se levar em conta, nessa perspectiva, que sempre houve mudanças culturais e, consequentemente, abordagens diferenciadas em cada período da história. Fazendo uma análise sobre o período contemporâneo, Almeida (2014, p. 193) diz:

Foram as TICs que estabeleceram uma rede global na qual sociedade com distintos modos de vida e histórias se entrecruzam. Esse novo ambiente causou um profundo impacto nos modos de vida cotidiana dos indivíduos, trazendo choques entre as culturas locais e fluxos culturais globalizados.

Continuando com a mesma abordagem, Almeida (2014, p.193) destaca:

$\mathrm{O}$ que procuramos destacar é que, cada vez mais, a cultura, associada à tecnologia, torna-se central na dinâmica das sociedades contemporâneas. A produção simbólica na assim chamada 'sociedade da informação cresce exponencialmente, por parte dos grandes conglomerados de mídia, mas, graças às TICs, também por parte de governos em seus diversos níveis, grupos, coletivos artísticos, indivíduos, comunidades, associações, etc. Nesse processo são geradas novas formas de solidariedade, de identidade, de ação social, assim como novas fontes de recursos econômicos. A presença de recursos humanos capacitados tanto no plano dos processos culturais, como no domínio de habilidades tecnológicas, torna-se um elemento de fundamental importância para o sucesso dessas iniciativas.

Percebe-se que essa inserção das novas tecnologias tem proporcionado mudanças aceleradas na cultura, havendo, assim, a substituição constante de ferramentas tecnológicas por outras mais apropriadas. Embora essas ferramentas possibilitem uma conexão de forma global, constata-se que nem todas as sociedades têm acesso a esses meios, mantendo-se isoladas do sistema global.

Para ajudar na compreensão do uso das novas TICs e as mudanças culturais será utilizado como referencial o trabalho de Manuel Castells, que ao analisar a sociedade do século XXI, enfoca a conexão como característica central, denominando-a sociedade em rede. Castells (2006, p.20) assim define:

A sociedade em rede, em termos simples, é uma estrutura social baseada em redes operadas por tecnologias de comunicação e informação fundamentadas na microelectrónica e em redes digitais de computadores que geram, processam e distribuem informação a partir de conhecimento acumulado nos nós dessas redes.

O autor esclarece que neste momento histórico a sociedade vive conectada com novas ferramentas de comunicação, porém os atores sociais necessitam dominá-las a fim de serem utilizadas como ferramentas de trabalho e não de dominação. Além disso, devem juntar os interesses individuais com os interesses coletivos. Assim, acrescenta:

Neste início do século XXI estamos numa encruzilhada do desenvolvimento da sociedade em rede. Estamos a testemunhar uma crescente contradição entre relações sociais tradicionais de produção e a potencial expansão de 
forças produtivas formidáveis. Esta pode ser a última contribuição da teoria marxista clássica. O potencial humano envolvido em novas tecnologias de comunicação e de genética, em redes, em novas formas de organização social e de invenção cultural, é verdadeiramente extraordinário. Contudo, sistemas sociais existentes travam a dinâmica da criatividade e, se desafiados pela competição, tendem a implodir (CASTELLS, 2006, p.29).

Conforme se compreende do autor, as novas ferramentas proporcionam uma nova forma de mediação - as redes sociais, denominada de redes. Em sua análise, essas novas abordagens se estendem para a economia e outras formas de negócios, e assim se faz necessária a elaboração de abordagens visando à compreensão dos novos dispositivos de armazenamento e de informação, visto que para que haja a mediação da informação, será necessária a compreensão dessas novas ferramentas. Recorre-se nessa trilha à posição de Gómez (2004, p.60):

[...] poderíamos dizer que, no início do século XXI, a crescente convergência tecnológica tem favorecido antes a reformulação que a solução de muitas das questões prévias. Hoje seguem existindo os problemas da reunião significativa de informações pertinentes e relevantes para uma questão e da exclusão do acesso às informações potencialmente públicas e livres, da maior parte da população; somam-se a estes outros problemas que denominaríamos "diáspora digital".

A Internet junta textos e inscrições documentárias, ao mesmo tempo em que desloca os sujeitos que a acessam de seus lugares de enunciação de ponto de partida, colocando-os em contextos heterológicos e polinômicos.

Para a autora essas abordagens tecnológicas proporcionam um novo locus de armazenamento da informação, possibilitando o acesso ao usuário de forma remota, necessitando de mudança na cultura de acesso informacional. Assim, pode se dizer que o novo ente de armazenamento da informação também se constitui em um instrumento de mediação da informação, como por exemplo, um site de notícias.

Outra abordagem a ser considerada refere-se à comunicação em rede. Nessa perspectiva, Marteleto (2010, pg. 28) aborda comunicação em rede de forma transversal, demonstrando que esse fato ocorre em todas as áreas das ciências humanas e ensina que:

[...] os estudos de redes sociais permitiram a construção de uma compreensão inovadora da sociedade, que ultrapassa os princípios tradicionais, nos quais o elo social é visto como algo que se estabelece em função dos papéis instituídos e das funções que lhes correspondem.

Percebe-se que as redes sociais permitem a aproximação das pessoas, proporcionam compartilhamento de informação, possibilitam a mobilização dos movimentos sociais e a realização de negócios, entre outras ações. 
Marteleto (2010) destaca que a abordagem acadêmica no Brasil sobre as redes sociais, no contexto da Ciência da Informação, se dá a partir da década de 1990 e vêm proporcionando ao indivíduo uma atuação como um ator em rede, desempenhando um papel social de forma mais ampla, alargando as suas relações interpessoais e extrapolando a sua territorialização. Além disso, vêm proporcionando às entidades da sociedade civil uma maior atuação relacionada às suas atividades políticas. Nesse sentido, Marteleto (2010, p.34) diz:

As relações entre Estado e movimentos sociais com mediação das organizações não governamentais (ONG), as questões de políticas públicas e a governança despertam o interesse da ciência política e da Economia, enquanto na Administração predominam os estudos sobre redes organizacionais e interorganizacionais, redes de cooperação entre pequenas e médias empresas, além dos arranjos produtivos locais (APL). Na Comunicação Social e na Ciência da Informação, de acordo com os resultados do levantamento, predominam os estudos sobre as relações interpessoais e as ações colaborativas na produção do conhecimento na Internet, as redes de conhecimento, as redes cognitivas, as comunidades de práticas, para o estudo dos processos de produção, organização, apropriação, gestão e uso do conhecimento.

O que se observa é que com a globalização proporcionada pelas TICs, as formas de comunicação vão se alterando, e é nessa perspectiva que surge a comunicação em redes sociais como um instrumento de mediação e informação. Esse novo meio vem proporcionando não somente uma relação interpessoal, mas a sua utilização passa ser ampliada para mobilizações dos movimentos sociais, bem com são utilizadas nas corporações e no comércio em geral.

\subsection{ECONOMIA INFORMACIONAL}

Com os avanços tecnológicos, há mudanças de paradigmas no campo da informação e do conhecimento e em consequência disso se faz necessária a busca de entendimento epistemológico das novas abordagens no campo da economia da informação.

Braman (2011, p. 41) expõe que:

No século XXI, a definição de informação como um leque de possibilidade tem particular importância e a economia da informação pode ser agora entendida como uma economia representacional - isto é, uma economia baseada em representações mais do que em informações empíricas, como os insumos críticos para tomadas de decisão econômica.

Assim, observa-se que as mudanças proporcionadas pelos avanços das tecnologias têm produzido alterações no regime global da política de informação, bem como na natureza da economia e na compreensão do conhecimento. De acordo com Braman (2011, p. 49) nos anos 
1970 começaram a surgir conceitos para definir economia de informação, contudo nos anos 1990 já havia surgido um novo conceito:

$\mathrm{Na}$ economia da informação, esses economistas argumentam que a cooperação e a coordenação são tão importantes quanto à competição para o sucesso econômico de longo prazo. Empresas isoladas estão sendo substituídas por 'empresas em rede' que mantêm fronteiras flexíveis e permeáveis através das quais se movem a propriedade intelectual, os recursos e apropria força de trabalho.

Pelo texto da autora, verifica-se a busca da atualização de novos conceitos em todas as áreas do saber, pois com as novas TICs, além da velocidade da divulgação da informação, circula o novo "fazer comércio" através de redes e dos dispositivos informacionais. Nesse sentido, Lastres e Albagli (1999, p. 8) expressam:

Do ponto de vista econômico, verificam-se novas práticas de produção, comercialização e consumo de bens e serviços, cooperação e competição entre os agentes, assim como de circulação e de valorização do capital, a partir da maior intensidade no uso de informação e conhecimento nesse processo. Tais práticas apoiam-se, por sua vez, em novos saberes e competência, em novos aparatos e instrumentais tecnológicos, tanto como em novas formas de inovar e de organizar o processo produtivo, expressando-se assim uma nova economia ou um novo padrão técnicoeconômico e ensejando também a necessidade de novas abordagens na própria teoria econômica e do valor.

A linguagem quanto às relações sociais muda constantemente, bem como mudam as abordagens, o que requer uma compreensão sobre as novas relações socioculturais, e nesse contexto também se altera a compreensão sobre a CI. As autoras complementam:

Esse novo papel da informação e do conhecimento nas economias vem provocando modificações substantivas nas relações, forma e conteúdo do trabalho, o qual assume um caráter cada vez mais 'informacional', com implicações significativas sobre o perfil do emprego. (LASTRES e ALBAGLI, 1999, p.9).

Dessa forma, são necessárias novas orientações referentes às relações econômicas e sociais, tanto pelos agentes públicos quanto pela sociedade de modo geral, visto que o comércio, ao se utilizar dessas novas ferramentas, embute nas notícias os seus negócios.

Albagli e Maciel (2004, p. 14) ao analisarem a informação e o conhecimento na perspectiva do desenvolvimento local afirmam:

A chamada era da informação e do conhecimento embora assumindo uma dimensão global, expressa: (a) a diferenciação entre realidades culturais e projetos de sociedade, ou seja, entre comunidades territoriais e segmentos 
sociais diversos; (b) a desigualdade entre sociedades com distintas condições de desenvolvimento, bem como entre segmentos de diferentes níveis socioeconômicos no interior de uma mesma sociedade.

Outro fator apontado pelas autoras refere-se às desigualdades territoriais no campo socioeconômico e que devem serem consideradas não somente na perspectiva da dimensão técnico-econômica, mas por meio da compreensão da informação e o conhecimento pela perspectiva da dimensão sociocultural, tendo presente à dimensão política histórica de cada época, sem se olvidar na qualidade de vida das pessoas.

Albagli e Maciel (2004, p. 15) destacam, ainda:

O conhecimento gerado a partir da realidade e das necessidades locais é relevante tanto para se obter vantagem competitiva, transformando as características e atributos específicos de cada território em valorização econômica, como também para promover padrões de desenvolvimento mais sustentável, em termos sociopolíticos, econômicos e ambientais.

As autoras dimensionam a concepção do desenvolvimento como sendo uma prática a ser observada a partir da realidade local, considerando a cultura específica, conflitando com o desenvolvimento linear. Assim, para que se possam compreender as propostas e ações governamentais sobre políticas regionais e sobre desenvolvimento se faz cada vez mais necessário o aprofundamento sobre a mediação da informação como instrumento de verificação e análise, se de fato há diálogo dos governantes e, no caso concreto no estado de Rondônia, com a sociedade em geral na perspectiva de se implantar políticas públicas visando à inclusão social, tanto no campo quanto nas zonas urbanas.

\subsection{ACERCA DO DESENVOLVIMENTO}

A temática do desenvolvimento é colocada como um eixo central nas discussões desde a década de 1950, com a estimulação da industrialização do Brasil a partir da década de 1930. Furtado (1981), ao analisar sobre esse processo, entende que em 1949 a indústria brasileira já havia ocupado espaço que proporcionava uma autossuficiência na produção dos bens duráveis e acrescenta:

Em 1959 a estrutura do sistema industrial havia evoluído consideravelmente com respeito à de um decênio antes. O setor metal-mecânico já era o mais importante, contribuindo com 27 por cento para a produção total. Os setores alimentar, têxteis e conexos representavam em conjunto 36 por cento. Entre 1949 e 1959 a produção metal-mecânica crescera com uma taxa média anual de 15,2 por cento, quase dobrando a intensidade do crescimento da produção manufatureira, que fora de 8,5 por cento. $O$ avanço na capacidade de autotransformação da economia era visível no fato de que a contribuição da 
indústria local à oferta de bens de capital passara nesse decênio de 36 para 66 por cento (FURTADO, 1981, p.32).

Como se observa, os anos de 1950 representaram no Brasil o avanço da produção industrial e dessa forma desencadeou o processo migratório do campo para as cidades. Furtado (1981, p.53) analisa que na década de 1960 havia fricções que se manifestavam no sistema econômico, e sobre a década de 1970 explica: “O comportamento global da economia brasileira, na segunda metade do decênio dos 70, revela um forte declínio na relação incremental produto-capital, com respeito ao período compreendido entre 1965 e 1974 e mais ainda com respeito à primeira metade daquele decênio". O autor acrescenta:

Existe presentemente no Brasil certo consenso, entre os próprios grupos dominantes, de que o estilo de desenvolvimento que se impôs com a industrialização produziu desigualdades sociais que se traduzem num fosso cada vez mais profundo entre uma minoria privilegiada e uma considerável massa rural e urbana. Também se reconhece que o regime autoritário implantado em 1964 agravou essa tendência à polarização social. A preocupação de reorientar o estilo de desenvolvimento se manifesta no discurso político mesmo daqueles que foram os maiores beneficiários do processo de contração da riqueza e da renda, traindo ansiedades. (FURTADO, 1981, p. 58)

Assim, observa-se que a política econômica no Brasil reflete um processo de dependência econômica e de exploração do trabalhador pelos "donos" do capital econômico. Sachs (2000, p.159), sobre a economia rural, explana: “[...] no Brasil e em vários países africanos, as potencialidades do desenvolvimento rural são ainda enormes e podem servir de alavanca para dinamizar os mercados internos". Ao se referir a Furtado, Sachs (2000, p.159) acrescenta: "Isso nos leva a um dos maiores ensinamentos de Celso, ou seja, que o mercado interno, a não ser em países excepcionalmente pequenos, constitui a base do processo de desenvolvimento". E ainda:

Podemos repensar toda a problemática do desenvolvimento em termos da apropriação efetiva do conjunto dos direitos humanos por todos, ou seja, direitos políticos e civis, direitos econômicos, sociais e culturais e direitos coletivos, como o direito ao meio ambiente, o direito à cidade, o direito à infância. Portanto terminarei dizendo que, para mim, o desenvolvimento é uma ideia forte para o século XXI, e não simplesmente um artefato no museu das ideias. (SACHS, 2000, p.160).

Na virada do milênio, ou seja, no século XXI, tantos os organismos internacionais, quanto os governos regionais, redobraram a atenção para essa temática, passando ocupar a centralidade do discurso. 
No contexto internacional, tanto os governos quanto as organizações multilaterais começam a se preocupar com o debate relacionado ao meio ambiente. Em 1969, o governo da Suécia propôs à Organização das Nações Unidas (ONU) a realização de uma conferência internacional para tratar dos problemas sobre meio ambiente. Essa proposta somente foi aceita após o desastre ecológico de Minamata, no Japão (1956), que levou à morte de centenas de pessoas contaminadas, principalmente pescadores, pelo mercúrio lançado ao mar pelas empresas locais.

Sobre a temática do desenvolvimento, Stavenhagen (1985, p.13) afirma que: “[...] nunca foram colocadas tão claramente quanto durante três décadas, do início dos anos 1950 até fins dos anos 1970, quando predominou, com algumas exceções notáveis, uma concepção linear evolucionista no pensar o desenvolvimento". Para o autor, essa concepção eurocêntrica defendia a tese de que os países considerados em desenvolvimento deveriam alcançar os padrões dos países do norte. Contudo, acrescenta que: “[...] um país deve concentrar seus recursos e esforços no sentido de produzir os bens essenciais, necessários à elevação dos padrões de vida dos mais pobres, antes de imitar os padrões de consumo e produção das nações industrializadas" (STAVENHAGEN, 1985, p.18). Observa-se, portanto, a necessidade de considerar as diferentes culturas existentes e não tomar como modelos as políticas adotadas nos países do norte, industrializados.

Nessa mesma perspectiva, Godelier (1981, p.38), ao abordar a relação do trabalho e a produtividade no contexto sobre desenvolvimento humano, afirma que: "Nas sociedades primitivas e rurais, o trabalho é uma operação dupla que tem o aspecto técnico e um aspecto mágico e ritual". Essa concepção nos proporciona uma compreensão de que o desenvolvimento não deve ser visto somente pelo viés econômico, mas deve levar em conta o modus vivendi de todas as culturas.

\subsection{DESENVOLVIMENTO SUSTENTÁVEL}

Devido às pressões internacionais, em 1972, foi realizado na cidade de Estocolmo, capital da Suécia, a Conferência das Nações Unidas sobre o Meio Ambiente Humano (CNUMAH), também conhecida como Conferência de Estocolmo. Essa conferência é considerada um marco para rever ações e debater temas relacionados ao equilíbrio entre o desenvolvimento econômico e a sustentabilidade do planeta. Dessa Conferência surgiu a concepção de Ecodesenvolvimento e que posteriormente foi substituída pela de Desenvolvimento Sustentável. 
Sobre o tema, Barbieri (1998, p.18) destaca:

O conceito de ecodesenvolvimento surgiu de uma polêmica dupla: de um lado os partidários do crescimento selvagem e, de outro, os que, vitimados pela absolutização dos critérios ecológicos, defendiam o crescimento zero [...] Essa última era a posição dos países desenvolvidos face à crise energética que já se tornava evidente naquela época e às altas taxas de crescimento populacional, principalmente nos países não desenvolvidos, que alimentavam as correntes migratórias em direção aos países desenvolvidos.

O autor analisa que a Conferência de Estocolmo foi a explicitação de conflitos entres países chamados desenvolvidos e os considerados não desenvolvidos ou em desenvolvimento. O Brasil, nessa Conferência, defendeu o conceito de desenvolvimento a partir da industrialização, como destaca Barbieri (1998, p. 20):

O Governo brasileiro naquela época (1972) empenhava-se na sustentação de uma política desenvolvimentista através da industrialização substitutiva de insumos industriais e da expansão das fronteiras agrícolas e dos distritos minerais em áreas de ecossistemas frágeis, como são as áreas de cerrado e da floresta amazônica. Com essa política adotada a ocupação da Amazônia se dá de forma desordenada, ou seja, sem levar em conta os habitantes daquela região.

Nesse período (1972) o Brasil estava sob o regime militar, adotando políticas desenvolvimentistas de integração nacional. Barbieri (1998, p. 21) destaca a importância da Conferência de Estocolmo como um marco histórico:

Apesar das divergências e da complexidade das questões em debate, a Conferência de Estocolmo de 1972 representou um avanço nas negociações entre países e pode-se dizer que ela constitui o marco fundamental na evolução para a terceira etapa da percepção dos problemas relacionados com o binômio desenvolvimento-meio ambiente.

De acordo com o autor, o termo ecodesenvolvimento aos poucos foi sendo substituído por desenvolvimento sustentável. Nesse sentido Barbieri (1998, p. 23) se manifesta: "Parece que a expressão desenvolvimento sustentável surge pela primeira vez em 1980 no documento denominado World Conservation Strategy, produzido pela IUCN e World Wildlife Fund (hoje), World Wide Fund for Nature - WWF)".

É possível considerar que o marco histórico no contexto do debate sobre sustentabilidade se deu na Conferência das Nações Unidas sobre Meio Ambiente e Desenvolvimento (CNUMAD), realizada no Rio de Janeiro em 1992, na chamada "Rio 92", ou como ficou conhecida: "Eco-92". Nessa conferência, reuniram-se líderes de 178 países, incluindo cerca de 100 chefes de estado. Paralelamente os movimentos sociais realizaram o 
Fórum Global das Organizações Não-Governamentais (ONGs) em que participaram cerca de 4.000 entidades da sociedade civil de todo o planeta. Nessa reunião, foram aprovados vários documentos de orientação política e social referentes à concepção de desenvolvimento sustentável, porém levou-se em conta a concepção adotada pelo relatório de Brundtland.

Nessa perspectiva Barbieri (1998, p. 23) destaca dizendo:

Para a Comissão Mundial sobre Meio Ambiente Brundtland, desenvolvimento sustentável é aquele que atende às necessidades do presente sem comprometer a possibilidade das gerações futuras de atenderem as suas próprias necessidades [...] o desenvolvimento sustentável é um processo de transformação no qual a exploração dos recursos, a direção dos investimentos, a orientação do desenvolvimento tecnológico e a mudança institucional se harmonizam e reforçam o potencial presente e futuro, a fim de atender às necessidades e aspirações humanas.

A parte desse referencial - ECO/92, o conceito de sustentabilidade entra na agenda internacional tanto dos governos, quanto das agências de fomento e organizações multilaterais, visando aprofundar o conceito de desenvolvimento sustentável com vistas à implementação de políticas públicas, levando em conta essa concepção. Vários autores vêm se debruçando sobre o tema e outro fator que deve ser destacado diz respeito ao manejo dos recursos renováveis.

Ximenes (1997, p. 335), ao analisar o padrão de desenvolvimento, chama atenção para a necessidade de haver uma aliança entre o econômico, o social e ambiente e expõe:

Existe um consenso de que o padrão de desenvolvimento, baseado em crescimento econômico e degradação ambiental, não deve mais ser aplicado, quer por países centrais, quer por países periféricos. Estabeleceu-se uma ideia comum de que esse tipo de desenvolvimento requer uma aliança entre a eficiência econômica, a equidade social e a prudência ecológica.

Dessa forma, cresce a necessidade de se aprofundar cada vez mais a concepção das teorias de desenvolvimento, não apenas pelo enfoque econômico, mas, sobretudo, com visão socioantropológica em que se leve em conta a qualidade de vida das populações nas mais variadas culturas.

Almeida (1998, p. 47), ao abordar sobre a concepção do desenvolvimento, referindose à agricultura e ao desenvolvimento sustentável, explica que

[...] os conceitos de desenvolvimento agrícola sustentável incorporam, de um modo geral, as preocupações de integrar a produtividade dos sistemas agrícolas a aspectos econômicos, sociais e ambientais. [...] No Brasil, as ONGs são as precursoras na utilização do conceito de agricultura e desenvolvimento rural sustentável. 
Já para Godard (1997) a noção de desenvolvimento sustentável serve, sobretudo na fase atual, para mostrar que o que está em jogo é a conciliação entre o desenvolvimento econômico e a proteção ao meio ambiente. Buscando uma maior compreensão sobre as concepções de desenvolvimento, o autor destaca o conceito de Brundtland, aprovado na ECO/92, como sendo a visão que se tornou mais conhecida:

As tensões entre estas três correntes encontram-se hoje amplamente nas propostas para dar um conteúdo ao objetivo de desenvolvimento sustentável. É certo que a definição mais conhecida é uma das citadas no relatório Brundtland (1988): 'O desenvolvimento sustentável é o que responde às necessidades do presente sem comprometer a capacidade das gerações futuras de responder às suas próprias necessidades'. (GODARD, 1977, p. 113).

Por outro lado, Godard (1977) analisa que a aplicação de uma política de desenvolvimento, tomando como base a sustentabilidade, não pode ser derivada diretamente nem de uma otimização econômica intertemporal, informada pelos preços observados nos mercados, nem dos conhecimentos científicos dos processos biofísicos, dos quais depende a reprodução de nosso meio ambiente.

Nessa perspectiva, Sachs (1998) destaca que o debate sobre desenvolvimento sustentável, em muitos casos, limita-se a dois aspectos: crescimento e sustentabilidade ecológica; deixando de lado o problema da sustentabilidade social, sem levar em consideração a dimensão cultural. Com essa abordagem, Sachs (2009, p.12) diz:

Devemos com urgência rever as nossas estratégias de desenvolvimento de maneira a torná-las socialmente includentes e ambientalmente sustentáveis. É claro que para que elas se materializem, é ainda necessário que haja crescimento econômico para sustentá-las. Em outras palavras, precisamos de soluções triplamente ganhadoras: no social, porque os objetivos de desenvolvimento são sempre sociais; no ambiental, porque não temos o direito de legar aos nossos filhos e netos um planeta inabitável, e no econômico, porque sem viabilidade econômica as coisas não acontecem. Este tripé de ecodesenvolvimento é sustentado por um duplo conceito ético: de solidariedade sincrônica com todos os passageiros da nave espacial Terra e de solidariedade diacrônica com as gerações futuras.

Nesse sentido, Sachs (2004, p.15-16) aponta “Os cinco pilares do desenvolvimento sustentável":

a- Social, fundamental por motivos tanto intrínsecos quanto instrumentais por causa a perspectiva de disrupção social que paira de forma ameaçadora sobre muitos lugares problemáticos do planeta;

b- Ambiental, com as suas duas dimensões (os sistemas de sustentação da vida como provedores de recursos e como 'recipientes' para a disposição de resíduos); 
c- Territorial, relacionado à distribuição espacial dos recursos, das populações e das atividades;

d-Econômico, sendo a viabilidade econômica a conditio sine qua non para que as coisas aconteçam;

e- Político, a governança democrática é um valor fundador e um instrumento necessário para fazer as coisas acontecerem; a liberdade faz toda a diferença.

Assim, faz-se necessário pensar um Estado que possa proporcionar políticas públicas capazes " $[. .$.$] de compatibilizar os objetivos sociais com a prudência ecológica, de articular$ entre si os espaços do desenvolvimento - do local ao regional, ao nacional, ao transnacional e de promover parcerias entre todos os atores públicos e privados, incluindo a sociedade civil organizada" (SACHS, 2009, p.13). O autor ainda enfatiza:

O Brasil tem todas as condições para se tornar um laboratório deste desenvolvimento includente e sustentável, valendo-se da sua extraordinária dotação de recursos naturais: a maior biodiversidade do mundo, a maior floresta tropical em pé, recursos hídricos abundantes, com a exceção do Polígono das Secas, climas variados e propícios à produção de biomassas. Estas vantagens comparativas naturais poderão ser potencializadas pela pesquisa e pela organização social adequada dos processos de produção (SACHS, 2009, p.13).

Com essa concepção de desenvolvimento includente, Sachs (2004) destaca que os governos devem estabelecer políticas públicas que venham ao encontro da sociedade como um todo, visando à superação das desigualdades sociais e aplicando políticas includentes, tais como: programa de assistência social, universalização da educação, da saúde, da moradia, garantia do trabalho, que levem em conta as pequenas propriedades rurais, bem como apoiem pequenas iniciativas de geração de renda, além de políticas públicas de inclusão para o uso das novas tecnologias.

Já sobre o desenvolvimento territorial local, Sachs (2004, p.61) destaca a necessidade de se elaborar políticas públicas que considerem iniciativas particulares de diferentes regiões e culturas.

A enorme diversidade das configurações socioeconômicas e culturais, bem como das dotações de recursos que prevalecem em diferente micro e mesorregiões, excluem a aplicação generalizada de estratégias uniformes de desenvolvimento. Para serem eficazes, estas estratégias devem dar respostas aos problemas mais pungentes e às aspirações de cada comunidade, superar os gargalos que obstruem a utilização de recursos potenciais e ociosos e liberar as energias sociais e a imaginação. Para tanto, deve-se garantir a participação de todos os atores envolvidos (trabalhadores, empregadores, o Estado e a sociedade civil organizada) no processo de desenvolvimento. 
Aqui se observa um dos fatores fundamentais em Sachs que é a valorização da democracia como um processo educativo da garantia direta da participação da sociedade, na formulação das políticas públicas e dessa forma possa possibilitar às comunidades locais e regionais a assumirem protagonismo e contribuírem no processo do seu próprio futuro.

\subsection{DESENVOLVIMENTO LOCAL}

Pensar o desenvolvimento local requer o entendimento dentro da concepção do desenvolvimento sustentável, visto que não se deve atender somente o aspecto econômico, mas o humano e o ambiental. Nesse sentido, Albuquerque e Zapata (2010, p. 214-215) esclarecem:

Por isso, é preciso realizar investimentos em capital humano, social e natural, além daqueles correspondentes ao capital econômico e financeiro. $\mathrm{O}$ enfoque do desenvolvimento local possui uma visão integrada dessas dimensões, a partir de um desenho que é realizado nos próprios territórios e com a efetiva participação dos atores locais. A política de desenvolvimento local é uma resposta dos diferentes territórios, cidades e regiões frente às exigências da mudança estrutural na atual fase de transição tecnológica.

O assunto abordado pelos autores traz o entendimento de que o desenvolvimento local requer a participação das comunidades locais, sem olvidar das mudanças e ferramentas decorrentes das novas tecnologias. Por outro lado, se faz necessário promover a descentralização política, visando à valorização da governança local.

Albuquerque e Zapata (2010), ao analisarem a necessidade das gestões municipais na perspectiva do desenvolvimento local, ressaltam a importância de investimentos na modernização e dessa forma, seja possível racionalizar os atos das administrações locais sobre gastos, possibilitando melhores investimentos nas necessidades das comunidades locais e assim destacam:

[...] os objetivos específicos da estratégia de desenvolvimento econômico local ressaltam as ações destinadas a aumentar a eficiência produtiva e a competitividade do sistema produtivo local. Dentre as ações direcionadas a aumentar a produtividade está à difusão das inovações pelo tecido produtivo e institucional; o incremento da qualificação dos recursos humanos e a melhoria das infraestruturas básicas. Por outro lado, as ações dirigidas a aumentar a competitividade devem assegurar o acesso à informação empresarial estratégica sobre mercados, produtos e tecnologias; potencializar as redes de comercialização dos produtos locais; ampliar seus mercados; assegurar os serviços pós-venda aos clientes; fortalecer as redes de atores locais públicos e privados; e estimular a cultura empreendedora local. (ALBUQUERQUE E ZAPATA, 2010, p. 223). 
Como se observa, a concepção de desenvolvimento local requer um planejamento que leve em conta tanto a capacitação permanente dos profissionais que trabalham na gestão municipal quanto na modernização de equipamentos que ajudarão no desempenho das ações locais. Por outro lado, Albuquerque e Zapata (2010, p. 224) expõem que na

[...] estratégia de desenvolvimento, é necessário assegurar a participação dos agentes interessados nos projetos. Para tal, é preciso manter viva a mobilização e a participação dos atores locais, estimulando e consolidando alianças, parcerias, acordos e redes de cooperação entre os atores territoriais.

Para Christoffoli (2010, p. 229) o conceito de desenvolvimento local não pode ser desvinculado ao fluxo dos mercados globalizados, mas em uma disputa de campo do território e explica:

Necessariamente, deve ser visto em sua dimensão de campo de disputa, de momento de conflito de interesses, especialmente num país de extremas desigualdades. O espaço local se constitui, portanto, num locus para o enfrentamento social e político, mais até do que o espaço central, num projeto de desenvolvimento.

A disputa nesse caso se estabelece no espaço da territorialização. Nesse sentido, o autor acrescenta:

Há também uma forte relação entre distribuição de terra e a democratização do poder. No Brasil, terra é mais do que terra, é cidadania que se exerce na possibilidade de o camponês não precisar mais 'viver de favor' na roça de terceiros, de poder 'olhar no olho' do fazendeiro, e não numa postura submissa. De poder votar e fazer campanha para o candidato que ele queira, e não para aquele imposto pelo coronel. (CHRISTOFFOLI, 2010, p. 263)

Denota-se que a posse da terra para os camponeses sem terra se constitui em um bem que se transforma em capital social, ou seja, a terra passa a proporcionar a cidadania local. Por outro lado, se converte em um campo de disputa pela hegemonia entre o grande capital e agricultor familiar. Nessa perspectiva Christoffoli (2010, p. 265) enfatiza:

Na medida em que democratiza o acesso a terra promovendo inclusão social e produtiva, e alavanca recursos do Estado, a luta pela terra também pode contribuir para constituir um novo eixo de desenvolvimento social e econômico para as regiões. Também é uma proposta mais concreta e aplicável do que pensar saídas ilusórias/mirabolantes indicadas apenas a poucos casos isolados. A agricultura permite instalar unidades produtivas razoavelmente sustentáveis sem grandes investimentos [...].

Para Coelho (2010) o debate sobre desenvolvimento regional/local deve levar em conta as desigualdades não somente no campo econômico, social e cultural, mas também o 
acesso à comunicação e à informação. Esses fatores estão intrinsecamente relacionados às questões da territorialização na sociedade globalizada.

[...] a dimensão estrutural da exclusão social só pode ser compreendida hoje em um contexto das novas ondas mundiais de expansão das tecnologias de informação e comunicação que geram movimentos desiguais e assimétricos, que por sua vez aprofundam desigualdades e territorializam ainda mais os processos de exclusão social. A transição de uma sociedade industrial capitalista para o capitalismo de uma sociedade do conhecimento estabelece novos padrões de desigualdades e de exclusão, presentes no campo da informação, do conhecimento e da comunicação. (COELHO, 2010, p.338).

Coelho (2010, p. 338-339) destaca ainda a necessidade do acesso à informação, visto que os dispositivos armazenam conhecimentos e dados informacionais, o que possibilita aos cidadãos o acesso, sendo, ainda, necessário o estabelecimento de políticas que permitam esse acesso.

Na sociedade da informação, o campo de disputa se dá na forma como o conhecimento é adquirido, armazenado, processado, transmitido e disseminado. Conhecimentos e saberes acumulados por longos anos podem ser armazenados em meios digitais e disponibilizados em rede aberta para todo o mundo. A extensão de redes abrange todas as esferas do conhecimento e suas potencialidades; a partir do acesso dependem de novos tipos de infraestrutura urbana e domiciliar. Suas aplicações e seu uso são desigualmente distribuídos entre diferentes atores, setores sociais, línguas, culturas, áreas de conhecimento, domínio de atividades, e exigem novos espaços de ensino e pesquisa na gestão do conhecimento.

O que se observa na posição do autor é que a falta de inclusão digital na chamada sociedade do conhecimento e da informação é mais uma forma de se ampliar as desigualdades regionais no que se refere ao mercado, além de afastar o cidadão do acesso à informação e como consequência, o distanciar da construção de políticas públicas. Dessa forma, a criação de políticas públicas visando estabelecimento de infraestrutura permitindo o acesso às redes sociais e aos dispositivos de informação são necessidades primárias. Nesse contexto, diz o autor:

A visão de inclusão digital como inserção das comunidades na sociedade do conhecimento deve se materializar por meio da disseminação e da garantia do direito à informação como elemento constituinte do direito à cidade. Incluído como um dos direitos que permite o usufruto equitativo das cidades segundo os princípios da sustentabilidade e da justiça, a garantia do direito à informação e ao conhecimento deve ser assegurada pela implementação de redes que garantam o acesso universal da população às redes mundiais de informação. (COELHO, 2010, p. 243). 
O processo da construção de políticas públicas para alcançar a inclusão digital, tanto de pessoas físicas, quanto de empresas, nas chamadas "cidades digitais", se constitui em uma necessidade irreversível, pois permitirá a integração tanto das zonas urbanas, quanto de distritos e zonas rurais, em atendimento a todas as políticas públicas.

Vaz, Ribeiro e Machado (2010), ao analisarem sobre a governança, destacam a necessidade dos governos disponibilizarem informações para o cidadão a fim de ele possa atuar como agente e possa acompanhar e intervir nas decisões adotadas pelos governos. Nesse sentido, expõem: "O governo não deve apenas promover a transparência pela disponibilidade das informações, mas deve proporcionar que estas informações cheguem aos cidadãos e seja compreendida" (VAZ; RIBEIRO; MATHEUS; 2010 p. 52). Por outro lado, com as novas TICs, o governo, através da internet, poderá permitir o acesso democrático a todos os cidadãos.

Da mesma forma, Vaz (2002), ao analisar a governança, leva em conta o uso das novas TICs e destaca:

A simples expansão do uso da tecnologia da informação pelos governos, ou a disseminação de aplicações que envolvam diretamente os cidadãos em suas relações com os governos não significam a criação de um quadro de governança eletrônica. Não é possível falar desta sem que se fale também da utilização da tecnologia da informação pelas organizações da sociedade civil em suas interações com os governos, o que evidencia o papel relevante da transformação dessas mesmas organizações pelo uso de recursos tecnológicos, em especial dos ambientes mediados por computador. (VAZ, 2002, p.1)

Verifica-se, na abordagem do autor, que com as novas tecnologias os governos precisam criar dispositivos de informações a fim possibilitar aos cidadãos e às organizações sociais, o acesso, e dessa forma, possam acompanhar as políticas adotadas, seus procedimentos de elaboração e obtendo integração da comunidade.

Por outro lado, Martins, Vaz e Caldas (2010, p. 264) ao abordarem sobre o tema desenvolvimento local como forma de tradução para execução das políticas públicas, afirmam que esse assunto é controverso, contudo destacam a dimensão do exercício da cidadania. "O desenvolvimento local também apresenta vários significados, comportando as diferentes dimensões em que se exerce a cidadania, e tem condições de criar um espaço de interação entre cidadãos, recuperando a iniciativa e a autonomia na gestão do que é público". Como observado, para se implantar a concepção do desenvolvimento local, é necessário o compromisso dos governos com a sociedade como um todo. Por outro lado, a sociedade civil deve estar organizada a fim de exercer a disputa do capital simbólico. 
Outro fator sobre as mudanças decorrentes das novas TICs diz respeito à relação do trabalho humano. Spangenberg (1998, p.21) explica que o "Desenvolvimento se refere a uma mudança, que implica em melhoria na maneira com a qual as pessoas se sustentam". Dessa forma, deve-se ter em mente que as novas TICs vem proporcionando novas abordagens no mundo do trabalho. Nesse sentido, Spangenberg (1998, p. 26) afirma:

Não só o número e a distribuição dos empregos vão mudar, mas também a organização do trabalho. As mudanças vão ser baseadas em maior participação dos trabalhadores e uma ampla aplicação de procedimentos que promovem decisões compartilhadas.

O que se percebe é que, com o avanço da robótica e sua apropriação tanto nas fábricas quanto nas lavouras, o trabalho que era executado por pessoas vai sendo transferido para novas formas da economia informacional ou automação referente à inteligência artificial.

Almeida (2007, p.110) ao abordar sobre a relação do trabalho com as novas tecnologias diz: “As inovações tecnológicas provocam uma cisão brutal na força-de-trabalho, separando um pequeno contingente, altamente qualificado e valorizado, das grandes massas pouco qualificadas que lutam com péssimas condições de trabalho e/ou desemprego". Verifica-se, ainda, as mudanças culturais decorrentes do emprego das TICs, ou seja, as relações humanas mudaram, assim como as formas das relações do trabalho. Nessa perspectiva, Almeida (2007, p.116) acrescenta:

A organização e a disseminação de estoque de informação têm que levar em conta a dinâmica sociocultural, tanto no plano 'global' como no plano 'local'. A criação de sistemas de informação, de redes de comunicação, não é apenas uma emulação da ideologia dominante ou mera fascinação tecnológica: é condição estratégica para a efetiva construção e circulação do conhecimento.

O que se pode denotar é que a busca do conhecimento, embora vise à compreensão da realidade local - no caso de um estudo regional, não pode deixar de abranger uma compreensão de elementos globalizantes, visto que as sociedades na atualidade se compreendem em redes sociais. A CI no contexto da mediação é fundamental para que se possa, por meio do estoque e armazenamento de informações, proporcionar estudos para ajudar na compreensão das novas linguagens e através delas compreender as políticas públicas implementadas. 


\subsection{MOVIMENTOS SOCIAIS NA ATUALIDADE E SEUS DESAFIOS}

A implantação das TICs, em todas as áreas das atividades humanas, vem ocorrendo com grande velocidade e gerando mudanças culturais nas mais diversas sociedades. Nessa perspectiva, também vêm ocorrendo mudanças no universo conceitual e nas formas de organização da sociedade civil.

Melucci (2001, p.22), ao analisar as formas de ação coletiva na atualidade, expõe:

O espaço social dos movimentos se constitui como uma área distinta do sistema e não coincide mais com as formas tradicionais de organização da solidariedade nem com os canais estáveis da representação política. A área dos movimentos se apresenta como 'setor' ou 'subsistema' do social.

O autor levanta a necessidade de se rever os conceitos tais como Estado e sociedade civil, bem como a concepção de público e privado. E assim destaca:

O mesmo conceito de 'movimento' nascido para indicar atores históricos que interferem sobre aspectos político-estatais, revela-se inadequado para descrever a realidade dos fenômenos coletivos organizados em redes, e difusos. Os 'movimentos' contemporâneos se apresentam como redes de solidariedade como fortes conotações culturais e, precisamente estas características, os diferenciam sempre mais claramente dos atores políticos ou das organizações formais (MELUCCI, 2001, p.23).

É importante analisar como se comportam as organizações sociais na sociedade em rede e como se constituem as novas formas de abordagem conceitual desse fenômeno, e assim diz Melucci (2001, p.27):

Sobre a mudança dos sistemas contemporâneos se refere, enfim, de modo corrente, como locuções alusivas (sociedade complexa, pós-industrial, tardocapitalística), assumindo a existência de uma lógica de sistema significativamente diversa daquela do capitalismo industrial.

Nesse sentido, Melucci (2001, p.27) complementa:

As sociedades complexas de alta densidade de informação requerem uma crescente autonomia dos elementos que as compõem; indivíduos e grupos devem funcionar como terminais confiáveis e capazes de auto-regulação e, por isso, estimulados a desenvolver habilidades formais de aprendizagem e de ação.

Observa o autor que existem comunidades e/ou grupos sociais que resistem às mudanças decorrentes das novas tecnologias e conservam heranças do passado configurando em resistência desses novos fenômenos. Ele destaca: "As sociedades nas quais vivemos, talvez mais do que outra sociedade do passado, agem sobre si mesmas, sobre seu próprio 
ambiente, sobre sua própria base biológica por meio da consciência científica e da tecnologia" (MELUCCI, 2001, p.88). Referindo-se aos movimentos sociais nas sociedades complexas Melucci (2001, p.97) acrescenta:

Os movimentos nas sociedades complexas são redes submersas de grupos, de pontos de encontro, de circuito de solidariedade que diferem profundamente da imagem do ator coletivo politicamente organizado [...] Antes de tudo observa-se a estrutura segmentada, reticular, policéfala [...] cada célula vive uma vida própria, completamente autônoma do resto do movimento, mesmo mantendo uma série de relações através da circulação de informações de pessoas; estas relações se tornam explícitas somente em ocasião de mobilizações coletivas e de saídas em torno das quais a rede latente ascende à superfície, para então mergulhar-se novamente no tecido quotidiano.

Outro fator que não se pode olvidar é a existência de formas permanentes de organização e lutas, bem como das pequenas redes de mobilização com objetivos latentes. Em contraposição, conforme Melucci (2001), nas sociedades pós-industriais, as mudanças se processam com uma grande velocidade no seu cotidiano.

Algumas características da cultura de ação dos movimentos sociais permanecem com socialização dos recursos cognoscitivos, criação de espaços de auto-reflexibilidade, autogestão, transitoriedade, produção de novas profissionalidades, especialmente no terreno simbólico e comunicativo. Melucci considera as temporalidades diferenciadas envolvidas continuidade das instituições e transitoriedade dos movimentos/mobilizações, e destaca:

Essa estrutura de representação pode fornecer notáveis benefícios ao sistema político na sua complexidade, porque as duas tendências têm uma funcionabilidade recíproca. A organização de interesses permanentes corre risco, continuamente, de burocratização corporativa, enquanto a organização dos interesses mutáveis corre o risco de dispersão e fragmentação. Portanto, a uma oferece continuidade organizativa, memória, capacidade de generalização: à outra introduz contínuas energias de mobilização antiburocrática. $\mathrm{O}$ risco principal é que se cristalize uma divisão estável do trabalho e uma hierarquia na importância das funções. A autonomia do espaço intermediário, chamado espaço público de representação, pode favorecer o intercâmbio, a circulação do pessoal e dos recursos organizativos. (MELUCCI, 2001, p. 141)

O conhecimento é um recurso fundamental para os atores conflituais dos movimentos sociais: permite revelar a natureza real das relações sociais por trás das aparências que os aparatos dominantes tendem a impor à vida coletiva. Nas sociedades sempre mais complexas, a cultura torna-se o terreno por excelência dos conflitos, e a produção de conhecimento, de informação, uma fonte de recursos importantes para a ação política. Desse modo, os espaços que produzem informação 
[...] são espaços "políticos" nos quais se encontram e se desencontram demandas provenientes dos atores sociais e exigências do sistema. Do mesmo modo, são espaços que caracterizam e difundem informações. Eles fazem parte daquele espaço público no qual podem ocorrer a participação e a representação das identidades coletivas. $\mathrm{Na}$ condição, porém, de que permanecem como espaços abertos ao confronto e à negociação dos interesses. Isso advém quando é reconhecida e salvaguardada a autonomia da função que desenvolvem. (MELUCCI, 2001, p. 143)

As mudanças tecnológicas sempre se constituíram como desafios para humanidade, porém observam-se mudanças aceleradas a partir da segunda guerra mundial. Esse fenômeno se torna mais visível a partir da segunda década do século XXI, que traz a concepção de uma economia compartilhada, trabalho remoto e/ou em rede.

Essa visão tem modificado as formas de organização da sociedade, que através de plataformas tecnológicas de bens e serviços possibilita novas formas tanto de comércio quanto de organização do trabalho.

Com as novas tecnologias agregadas à essas plataformas de serviços, Tigre e Pinheiro (2019, p. 13) analisam sobre as relações sociais no mundo do trabalho na atualidade:

Recursos humanos ociosos também podem ser aproveitados por meios de sites de compartilhamento. Plataformas como Uber, Grupon, entre outras, permitem que trabalhadores autônomos prestem serviços diretamente a clientes. Prestadores de serviços autônomos dependem de uma rede de contatos pessoais difícil de estabelecer. Por outro lado, os consumidores também enfrentam dificuldades para encontrar bons prestadores de serviços, em razão dos custos de transação inerentes aos processos de busca e experimentação. Por meio de plataforma de compartilhamento, eles podem não apenas ampliar suas opções como também ter uma avaliação prévia da qualidade dos serviços prestados pelo profissional.

Já na segunda década do século XXI, observa-se um processo acentuado da precarização do trabalho, ou em outro termo, chamada de "uberização" que envolve vários setores na prestação de serviços, não somente no comércio, mas também nos serviços públicos, outrora denominados essenciais. O trabalhador na luta pela sobrevivência e impulsionado pelas novas tecnologias, busca alternativas dentro dessa nova concepção de trabalho compartilhado, mantendo a sensação de que é trabalhador autônomo e/ou um pequeno empresário.

Rusche e Santini (2016) abordam que a concepção da economia inteligente vem ganhando força na atualidade, da mesma forma em que ganham força os serviços compartilhados tendo como base a internet. Segundo as autoras, "O fenômeno está diretamente relacionado à fase atual do capitalismo e se repete, em diferentes intensidades, em todo o planeta" (RUSCHE; SANTINI, 2016, p.11). Por outro lado, colocam-se em 
discussão novas formas de organização de trabalho, na perspectiva de minimizar os serviços denominados de uberizados. Dessa forma, Rusche e Santini (2016, p. 13) destacam:

\begin{abstract}
Não se trata de ignorar essas novas relações fundamentadas na confiança entre pessoas. Nem abandonar a perspectiva de melhor uso de objetos ou deixar de crer em formas de trabalho mais dignas. Mas sim fazer isso de maneira realmente inteligente, de modo a contribuir com a construção de novas formas de organização social e econômica. Em contraposição aos novos arranjos ubercapitalistas ultraneoliberais [...]
\end{abstract}

Assim, a economia informacional, ou de compartilhamento, impõe novas relações sociais e de trabalho para a sociedade, e vem possibilitando a criação de novos arranjos cooperativas de compartilhamento, visando minimizar as novas relações de trabalho.

Zanatta (2016, p. 62), ao tratar das novas formas sobre as relações de trabalho relacionado às novas tecnologias compartilhadas, acrescenta que "O cooperativismo de plataforma é um termo que descreve mudanças tecnológicas, culturais, políticas e sociais. $\mathrm{O}$ cooperativismo de plataforma é um horizonte da esperança. Não é uma utopia concreta; é uma economia emergente" e, ainda:

Outra proposta sedutora e imaginária é a ideia de cooperativas de trabalho se formando dentro da barriga da economia do compartilhamento. Motoristas da Uber poderiam usar a infraestrutura técnica da empresa para formar seus próprios empreendimentos. Tal tomada hostil pelos trabalhadores poderia ser imaginada como o resultado de uma ação antitruste comparável àquela que foi movida contra a Microsoft após o lançamento do Internet Explorer. (ZANATTA, 2016, p.72)

Dessa forma, tudo indica que os novos movimentos de organização dos trabalhadores no século XXI, devido às novas TICs, vão tomar uma direção na perspectiva da autogestão, visto que as formas da empregabilidade vão tomando nova direção, ou seja, dentro do processo da economia compartilhada.

Santos (2020), ao fazer uma abordagem sobre o modo de vida na atualidade imposta pelo sistema que ele chamou de hipercapitalismo, avalia que esse modelo não deve ser visto como alternativa para as sociedades na atualidade. A abordagem do autor parte de uma análise da crise estabelecida a partir da pandemia de COVID-19, em 2020, e busca compreender a ausência do Estado, na construção das políticas públicas, deixando para a iniciativa privada resolver questões fundamentais, como serviços públicos de saúde, de habitação, de assistência social, entre outros. Assim, explica:

[...] o neoliberalismo combinado com o domínio do capital financeiro - está social e politicamente desacreditada em face da tragédia a que conduziu a sociedade global e cujas consequências são mais evidentes do que nunca 
neste momento de crise humanitária global. $\mathrm{O}$ capitalismo poderá subsistir como um dos modelos económicos de produção, distribuição e consumo entre outros, mas não como único e muito menos como o que dita à lógica da acção do Estado e da sociedade. Ora, foi isto o que aconteceu nos últimos quarenta anos, sobretudo depois da queda do Muro de Berlim. Impôs-se a versão mais anti-social do capitalismo: o neoliberalismo crescentemente dominado pelo capital financeiro global. Esta versão do capitalismo sujeitou todas as áreas sociais - sobretudo saúde, educação e segurança social- ao modelo de negócio do capital, ou seja, a áreas de investimento privado que devem ser geridas de modo a gerar o máximo lucro para os investidores. Este modelo põe de lado qualquer lógica de serviço público, e com isso ignora os princípios de cidadania e os direitos humanos (SANTOS, 2020, p. 24).

A diminuição do Estado, imposto a partir da década de 1980 e definida como sendo o Acordo de Washington ou Consenso de Washington, ocorrido em 1989, determinada por organizações financeiras internacionais como Fundo Monetário Internacional (FMI), Banco Mundial e Departamento do Tesouro dos Estados Unidos, estabeleceu metas para os países em desenvolvimento que para receberem apoio financeiro, teriam que diminuir o Estado, ou seja, privatizar o seu patrimônio estatal e fazer mudanças em suas constituições visando retirar direitos sociais adquiridos e assim, denominado de neoliberalismo.

Santos (2020, p.27) destaca os princípios que norteiam a sociedade na atualidade dizendo:

Os três princípios de regulação das sociedades modernas são o Estado, o mercado e a comunidade. Nos últimos quarenta anos foi dada prioridade absoluta ao princípio do mercado em detrimento do Estado e da comunidade. A privatização dos bens sociais colectivos, tais como a saúde, a educação, a água canalizada, a electricidade, os serviços de correios e telecomunicações e a segurança social, foi apenas a manifestação mais visível da prioridade dada à mercantilização da vida colectiva.

Mais insidiosamente, o próprio Estado e a comunidade ou sociedade civil passaram a ser geridos e avaliados pela lógica do mercado e por critérios de rentabilidade do 'capital social' (Sic).

O autor, ao analisar as prioridades do Estado na visão neoliberalista, ou seja, entre os bens públicos - Estados e a comunidade, se prestigia o mercado. Nessa perspectiva, passa a entender a sociedade civil na lógica do 'capital social', contudo faz-se necessária uma retomada do processo civilizatório, a serem levadas em conta todas as formas de vida no planeta terra a fim de se manter a sustentabilidade. Nesse sentido, afirma:

Só com uma nova articulação entre os processos políticos e os processos civilizatórios será possível começar a pensar numa sociedade em que humanidade assuma uma posição mais humilde no planeta que habita. Uma humanidade que se habitue a duas ideias básicas: há muito mais vida no planeta do que a vida humana, já que esta representa apenas $0,01 \%$ da vida 
existente no planeta; a defesa da vida do planeta no seu conjunto é a condição para a continuação da vida da humanidade. De outro modo, se a vida humana continuar a pôr em causa e a destruir todas as outras vidas de que é feito o planeta Terra, é de esperar que essas outras vidas se defendam da agressão causada pela vida humana e o façam por formas cada vez mais letais. Nesse caso, o futuro desta quarentena será um curto intervalo antes das quarentenas futuras (SANTOS, 2020, p.31).

O que se pode verificar na manifestação do autor é de que o modelo neoliberal está em crise e que não se constitui como modelo hegemônico entre as distintas sociedades. Nesse sentido, observa-se que há países que buscam formas de atuação fora do modelo neoliberal. Outro fator que deve ser levado em conta é o papel da sociedade civil, pois não se pode olvidar da existência de diferentes classes sociais, implicando na existência da disputa permanente pela hegemonia.

\subsection{CAMPO SOCIAL E A DISPUTA PELA HEGEMONIA}

$\mathrm{Na}$ abordagem da relação do Estado ou sociedade política com a sociedade civil será considerado o referencial em Gramsci, dada a sua influência em Melucci e algumas homologias estruturais com o pensamento de Bourdieu, no que tange às disputas por hegemonia no campo.

Nesse sentido, Andrade (2001, p.21) demonstra: "Na concepção gramsciana, a cultura e política estão intrinsecamente relacionadas, pois a cultura é um dos instrumentos da práxis política”. Dessa forma, para que haja mudanças na sociedade, se faz necessário que haja uma mudança criadora da história, isto é, uma mudança na cultura.

Um dos temas centrais do pensamento de Gramsci refere-se ao papel do intelectual orgânico. Ao abordar o tema, o autor questiona se os intelectuais se constituem em um grupo social independente ou se são representantes de uma determinada classe ou de um determinado projeto social.

Cada grupo social, nascendo no terreno originário de uma função essencial no mundo da produção econômica, cria para si, ao mesmo tempo, de um modo orgânico, uma ou mais camadas de intelectuais que lhe dão homogeneidade e consciência da própria função, não apenas no campo econômico, mas também no social e no político [...] (GRAMSCI, 1991, p.4).

Nessa abordagem, pode-se entender que o intelectual orgânico pensado por Gramsci desempenha um papel engajado na elaboração e representação das aspirações da classe que o representa. Assim, considerando a concepção de sociedade civil e sociedade política, Gramsci 
entende o conceito de sociedade civil como sendo uma organização privada visto que se manifesta com relativa autonomia em relação à sociedade política, ou seja, o Estado.

Bourdieu, por outro lado, busca compreender a sociedade como tendo uma estrutura dinâmica; os agentes atuam dentro de campo social diverso; os valores socioculturais são derivados de habitus, ou seja, de um aprendizado na sociedade onde está inserido. A intervenção do agente o denomina de capital simbólico, não se tratando de uma ação natural e sim cultural.

Ao tratar das estruturas sociais em diferentes culturas, enfatiza que os valores culturais são reproduzidos de forma inconsciente e dessa forma Bourdieu $(2015$, p.295) expõe que a:

[...] reprodução das estruturas entendidas como sistemas de relações objetivas capaz de transmitir suas propriedades de relação aos indivíduos aos quais tais propriedades preexistem e aos quais sobrevivem, não tem nada a ver com o registro analítico das relações que se estabelecem no âmbito de determinada população. Este postulado tanto se aplica à conexão entre o êxito escolar das crianças e a posição social de suas famílias como no caso das relações entre as posições ocupadas pelas crianças e pelos pais.

Como se pode observar, o autor trabalha a escola como um campo de disputa, bem como um repositório de informações e conhecimento, ao mesmo tempo como mediadora do capital cultural da sociedade em que está inserida, assegurando assim a reprodução das estruturas da classe social dominante, ou seja, funcionando como um aparelho ideológico do sistema. Outro fator diz respeito ao conceito de campo social em Bourdieu, Thiry-Cherques (2006, p.36) destaca:

Por definição, o campo tem propriedades universais, isto é, presentes em todos os campos, e características próprias. As propriedades de um campo, além do hábitus específico, são estruturas, a doxa, ou a opinião consensual, as leis que o regem e que regulam a luta pela dominação do campo. Aos interesses postos em jogo Bourdieu denomina 'capital' - no sentido dos bens econômicos, mas também do conjunto de bens culturais, sociais, simbólicos etc.

Assim, pode-se perceber que o conceito de campo é um espaço onde se estabelece violência simbólica na busca da hegemonia. Nesse sentido, Thiry-Cherques (2006, p.38) destaca que "A vida social é governada pelos interesses específicos do campo". Assim, o campo é compreendido como sendo um espaço das lutas pela hegemonia.

Almeida (2018, p.220), ao analisar o trabalho de Bourdieu, diz que "Dependendo do país ou do campo de recepção, ele será lido como sociólogo da educação ou da cultura, epistemólogo das Ciências Sociais, um intelectual francês pós-estruturalista ou um crítico 
engajado da globalização". Por outro lado, Almeida (2018), ao avaliar a atual conjuntura no processo acelerado de mudanças decorrente das novas TICs, destaca a necessidade do pesquisador social se debruçar sobre as mudanças culturais inseridas na globalização, assim expõe:

\begin{abstract}
Um momento em que os laços sociais e os produtos culturais estão imersos em fluxos globalizados de comunicação e informação, reconfigurando novas possibilidades e formas de leitura, aprendizagem e interação. As novas mídias, redes e plataformas digitais estão redefinindo as formas de produção, acesso e apropriação do conhecimento, e, portanto, modificando as formas pelas quais os capitais sociais, culturais e informacionais são construídos pelos sujeitos - individuais e coletivos. Nesse sentido, uma abordagem socioantropológica do conhecimento revela-se estratégica para a compreensão dos fenômenos que a Ciência da Informação busca compreender, tornando prioritário refletir acerca do pensamento de um autor que esteve sempre com o olhar atento para os processos de dominação simbólica e de diferenciação social. (ALMEIDA, 2018, p. 221).
\end{abstract}

O autor aborda a importância da compreensão do pensamento de Bourdieu na perspectiva da sociedade globalizada, que usa como ferramenta de comunicação as novas TICs, porém a análise socioantropológica deverá ser utilizada como metodologia para se compreender as mudanças socioculturais estabelecidas por esses novos fenômenos. Além disso, deve ser levado em conta o campo em que se estabelece a relação do poder simbólico entre os atores da sociedade.

Por outro lado, Bourdieu analisa as relações sociais através de capitais, tais como: econômico, social, cultural, intelectual e simbólico. Na busca pela hegemonia se organiza a disputa que se dá no campo. Nesse sentido, verificam-se as concepções ideológicas que se estabelecem na disputa pelo controle do poder hegemônico, ou seja, pelo estabelecimento de direção do Estado e concomitantemente da sociedade. Assim, pode se dizer que a hegemonia é um complexo sistema de relações e de mediações que se disputa no seio das sociedades.

Buscando elaborar uma abordagem comparativa entre Gramsci e Bourdieu, Burawoy (2010, p. 50) explica que “[...] ambos desenvolveram concepções bastante sofisticadas acerca das lutas de classe; ambos focaram o mesmo aspecto social, aquilo que Gramsci chamou de superestruturas do capitalismo e Bourdieu chamou de campos de dominação simbólica". Outro fator que marca a diferença entre os dois pensadores é que enquanto Gramsci entende que a formação do intelectual orgânico se dá através do partido político, para Bourdieu essa formação se dá na escola, na academia e nessa perspectiva é que se dá a formação do capital intelectual e cultural, e, por conseguinte, se processa a disputa no campo, na busca pela hegemonia. 
Burawoy (2010, p. 60) destaca a posição de Gramsci referente ao intelectual orgânico:

O intelectual orgânico só poderia ser eficaz por meio da relação íntima com a classe, o que, para algumas interpretações gramscianas, implicaria ter ele mesmo vindo da classe operária. $O$ intelectual orgânico não é nenhum indivíduo isolado; é sim alguém imerso em uma organização específica: o partido político - entidade análoga ao que a universidade era para Bourdieu.

Da mesma forma, Burawoy vai destacar, na visão de Bourdieu, sobre a formação e atuação do intelectual orgânico, que se dá no campo acadêmico, tanto daqueles que querem manter o sistema, quanto os que almejam mudanças, aí se constituem o campo da disputa. Por outro lado, os trabalhadores submetidos à dominação do capital simbólico do sistema capitalista e vencidos pela ideologia dominante, passam a ser explorados, perdendo assim a capacidade de reagir ao sistema.

Apenas os dominadores e particularmente os intelectuais poderiam distanciar-se dessa estrutura social e objetivar (analisar) sua relação com ela. Apenas eles podem ter acesso a seus segredos. Mas não todos os intelectuais, para ser exatos; apenas aqueles que conseguem compreender a dominação, que são reflexivos à sua condição especial no mundo e que usam tal reflexividade para examinar à vida dos outros (BURAWOY, 2010, p.102).

Assim, pode-se dizer que o que muda são as concepções e formas de organização da classe explorada, visto que a disputa é no campo simbólico pelo controle do poder hegemônico, ou seja, pelo estabelecimento de direção da sociedade.

Bourdieu (2011, p. 99-100), ao analisar o papel do Estado, destaca como sendo um ente de controle de todos os tipos de capital, porém é através do domínio do capital simbólico e do capital coercitivo que se visibiliza a presença do Estado.

O Estado é resultado de um processo de concentração de diferentes tipos de capital, capital de força física ou de instrumentos de coerção (exército, politica), capital econômico, capital cultural, ou melhor, de informação, capital simbólico, concentração que, enquanto tal, constitui o Estado como detentor de uma espécie de metacapital, com poder sobre os outros tipos de capital e sobre seus detentores. A concentração de diferentes tipos de capital (que vai junto com a construção dos diversos campos correspondentes) leva, de fato, à emergência de um capital específico, propriamente estatal, que permite ao Estado exercer um poder sobre os diversos campos e sobre os diferentes tipos específicos de capital [...].

Como se percebe, o Estado, enquanto estrutura de poder, centraliza os diferentes tipos de capital e se constitui como o espaço ou campo de disputa pelos diferentes tipos de capital. Segundo Bourdieu (2011), o Estado aglutina todos os tipos de capital, devendo se destacar a 
concentração do capital simbólico, vinculado pelas questões morais e dessa forma age como predominância do capital econômico, social, político e cultural.

Essas reflexões acerca das concepções de Bourdieu em torno das disputas de campo pelo controle - direto ou indireto - do Estado fornecem perspectivas e parâmetros para buscar compreender as dinâmicas políticas que se dão em relação ao desenvolvimento local, as oposições e alianças, bem como as articulações com os níveis regionais e nacionais que influem nesse processo.

O que se pode observar é que, com as novas Tecnologias da Informação e do Conhecimento (TICs) nesse período da globalização, as mudanças culturais vêm exigindo novas adaptações e capacitação dos agentes operadores das novas ferramentas de comunicação. Esse modelo tem exigido novas formas de ações tanto no campo da economia de mercado, quanto das relações de trabalho do campo e da cidade, e dessa forma exigindo novas formas de organização tanto da sociedade política, no que se refere ao governo, quanto das lutas da sociedade civil.

Observa-se, por outro lado, que as sociedades afastadas dos grandes centros - no caso do Brasil as sociedades originárias (indígenas) e tradicionais (ribeirinhos, quilombolas e extrativistas) - não estão conectadas com as novas TICs; contudo, deve-se verificar que o padrão de vida desses povos não deve ser compreendido como sendo o de sociedades atrasadas, mas devem ser entendidos no seu "modus vivendi". 


\section{RONDÔNIA NO CONTEXTO REGIONAL}

Neste capítulo será abordado o processo da territorialização do estado de Rondônia dentro do contexto da ocupação da Amazônia. Também serão destacados os grandes projetos de investimentos na região na perspectiva histórica, bem como dentro de um marco referencial no contexto socioeconômico dos projetos governamentais recentes.

O Estado de Rondônia, antes território federal do Guaporé e posteriormente Território Federal de Rondônia ${ }^{3}$, foi criado pela Lei Complementar n ${ }^{\circ}$ 41, de 22 de dezembro de 1981, e está localizado na região norte do Brasil, fazendo fronteira com a Bolívia e com os estados do Amazonas, Mato Grosso e Acre; possui 52 municípios e ocupa uma área de 237.590,547 km². Sua capital é Porto Velho, situada nas margens do Rio Madeira, maior afluente do rio Amazonas.

O estado de Rondônia, diferente dos outros estados da região norte, mesmo sendo banhado pelo rio Madeira, está interligado por rodovias que permitem o acesso rodoviário a todos os municípios do Estado, bem como através da BR 364 é possível o acesso ao estado do Acre e aos estados do sul do país, e da BR 319 o acesso ao estado do Amazonas e consequentemente à Venezuela. Por hidroviário, por meio do rio Madeira, permite o escoamento da produção para o oceano atlântico. Destaca-se, ainda, a existência de rodovia denominada transoceânica que interliga aos países andinos como Bolívia, Peru, Equador e Chile, possibilitando conexão via Oceano Pacífico.

\footnotetext{
3 “O Território do Guaporé compreendia, originalmente, os municípios de Porto Velho, Guajará-Mirim, Manicoré e Humaitá. O Decreto-Lei Federal 7.470, de 17 de abril de 1945, determinou os seus limites definitivos: dois municípios apenas, Porto Velho (6 distritos) e Guajará-Mirim (3 distritos), com uma superfície total de $243.044 \mathrm{~km} 2$ (1541. 136 e $88.900 \mathrm{~km} 2)$. A lei 2.731, de 17 de janeiro de 1956, dará ao Território o nome de Rondônia, em homenagem ao Marechal Mariano da Silva Rondon [...]" (THÉRY, 2012, p.55). O nome Guaporé, foi em homenagem ao rio Guaporé que faz divisa entre o Brasil e a Bolívia. O objetivo da criação do Território era estimular a ocupação humana na região. .
} 
Figura 1 - Localização geográfica de Rondônia

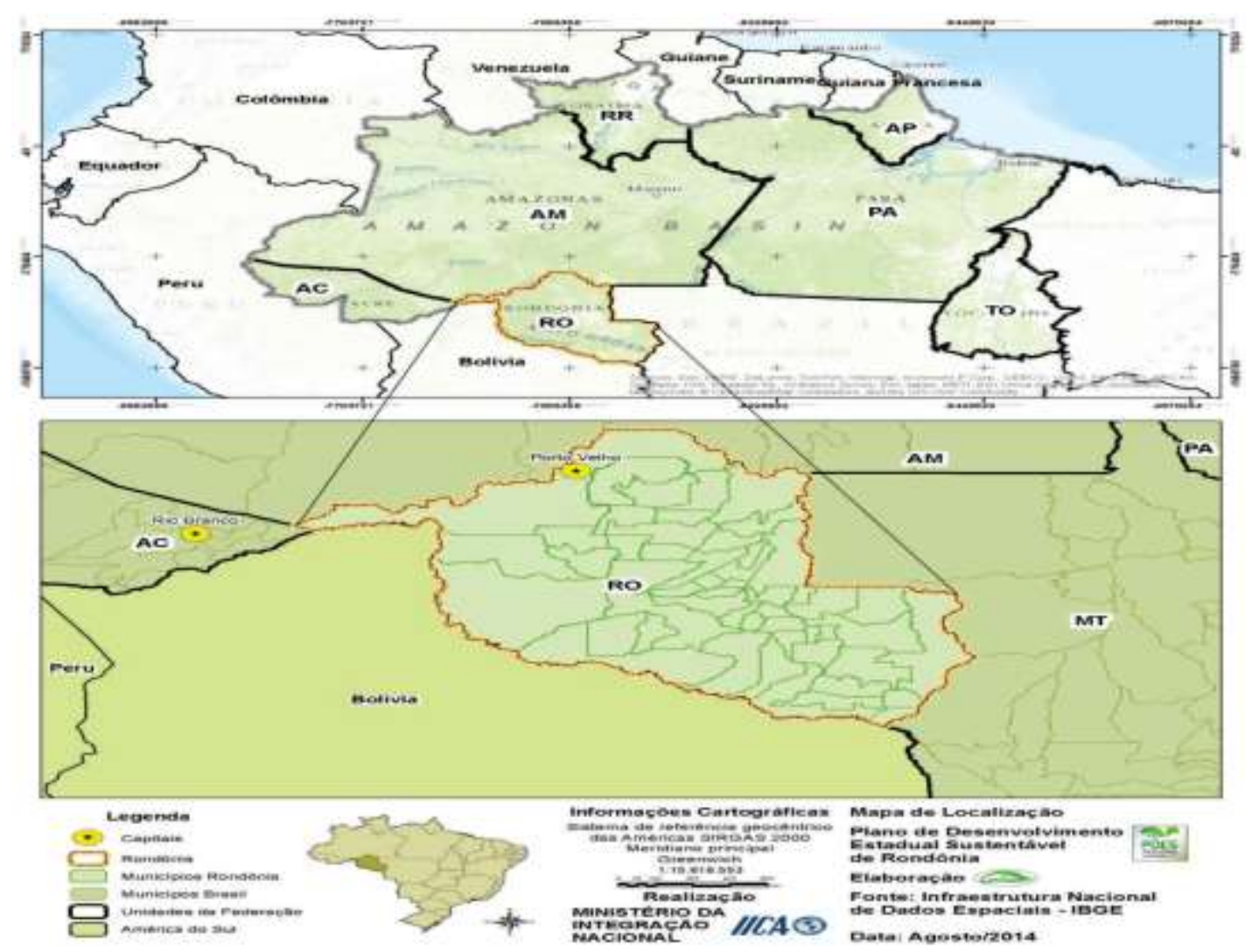

Fonte: PDES, 2015

\subsection{A BORRACHA COMO OURO BRANCO DA AMAZÔNIA}

Para poder ter uma maior compreensão das políticas públicas no estado de Rondônia, faz-se necessária uma pequena abordagem histórica sobre o processo de ocupação do território amazônico brasileiro que se deu desde o período inicial da colonização no século XVII, quando da busca das chamadas "drogas do sertão", motivando a penetração de imigrantes na floresta.

Deve-se ressaltar que, por outro lado, conforme Veríssimo e Pereira (2020), os indígenas chegaram à Amazônia cerca de 11.000 a.C., oriundos da Ásia. Os autores vão dizer que ao longo da história "Essas populações desenvolveram uma rica diversidade cultural que incluía desde grupos nômades de caçadores-coletores até grandes aldeias de povos que praticavam agricultura, pesca de larga escala e caça intensiva" (VERÍSSIMO e PEREIRA, 2020, p.21). 
Os europeus ficaram muito surpresos no início do século 16 quando desembarcaram no vale do Amazonas e encontraram comunidades relativamente superpovoadas. Alguns assentamentos indígenas possuíam de 20 mil a 50 mil habitantes. Entretanto, essas sociedades amazônicas sofreram grandes impactos a partir da chegada desses exploradores (VERÍSSIMO e PEREIRA, 2020, p.26).

Com a ocupação da Amazônia pelos colonizadores portugueses, as populações indígenas foram sendo dizimadas por massacre e/ou por doenças transmitidas pelos brancos. "À época do primeiro contato europeu havia aproximadamente 5,5 milhões de índios na bacia amazônica, dos quais 3 milhões viviam no Brasil. Atualmente há apenas cerca de 430 mil indígenas na Amazônia” (VERÍSSIMO e PEREIRA, 2020, p. 26).

Nos séculos XIX e XX, devido à descoberta do látex (goma elástica) como matéria prima para fabricação tanto da indústria pneumática, quanto da indústria calçadista e seus derivados, a região sofreu uma grande corrida na busca da extração do chamado "ouro branco", a despeito de sua ascensão e queda, essa economia conformou os primeiros assentamentos humanos na região.

Na busca da extração da borracha na Amazônia, a única forma de acesso às florestas se dava pelos rios. Dessa forma, pode se verificar que os primeiros assentamentos humanos ocorreram nas margens dos rios, depois transformados em cidades, como entrepostos para o escoamento da produção da borracha. Os pontos de referência nesse período eram as cidades de Belém e de Manaus.

Quadro 1- Produção de borracha natural (1856-1939)

\begin{tabular}{|l|c|c|c|c|c|}
\hline Ano & Quantidade & Ano & Quantidade & Ano & Quantidade \\
\hline 1856 & 1.906 & 1903 & 29.076 & 1915 & 29.772 \\
\hline 1861 & 2.515 & 1904 & 27.086 & 1916 & 28.305 \\
\hline 1866 & 5.434 & 1905 & 31.887 & 1917 & 29.217 \\
\hline 1871 & 6.765 & 1906 & 31.364 & 1918 & 33.252 \\
\hline 1876 & 7.900 & 1907 & 34.453 & 1919 & 23.586 \\
\hline 1881 & 8.506 & 1908 & 34.270 & 1920 & 17.329 \\
\hline 1886 & 12.690 & 1909 & 34.700 & 1921 & 19.855 \\
\hline 1891 & 16.650 & 1910 & 34.248 & 1922 & 14.138 \\
\hline 1896 & 19.500 & 1911 & 33.518 & 1930 & 12.370 \\
\hline 1900 & 23.650 & 1912 & 37.178 & 1935 & 11.961 \\
\hline 1901 & 27.940 & 1913 & 32.141 & 1939 & -- \\
\hline 1902 & 27.120 & 1914 & 29.925 & -- & \\
\hline
\end{tabular}

Fonte: Andrade (2001, p.20) 
Gráfico 1 - Crescimento e queda da produção da borracha

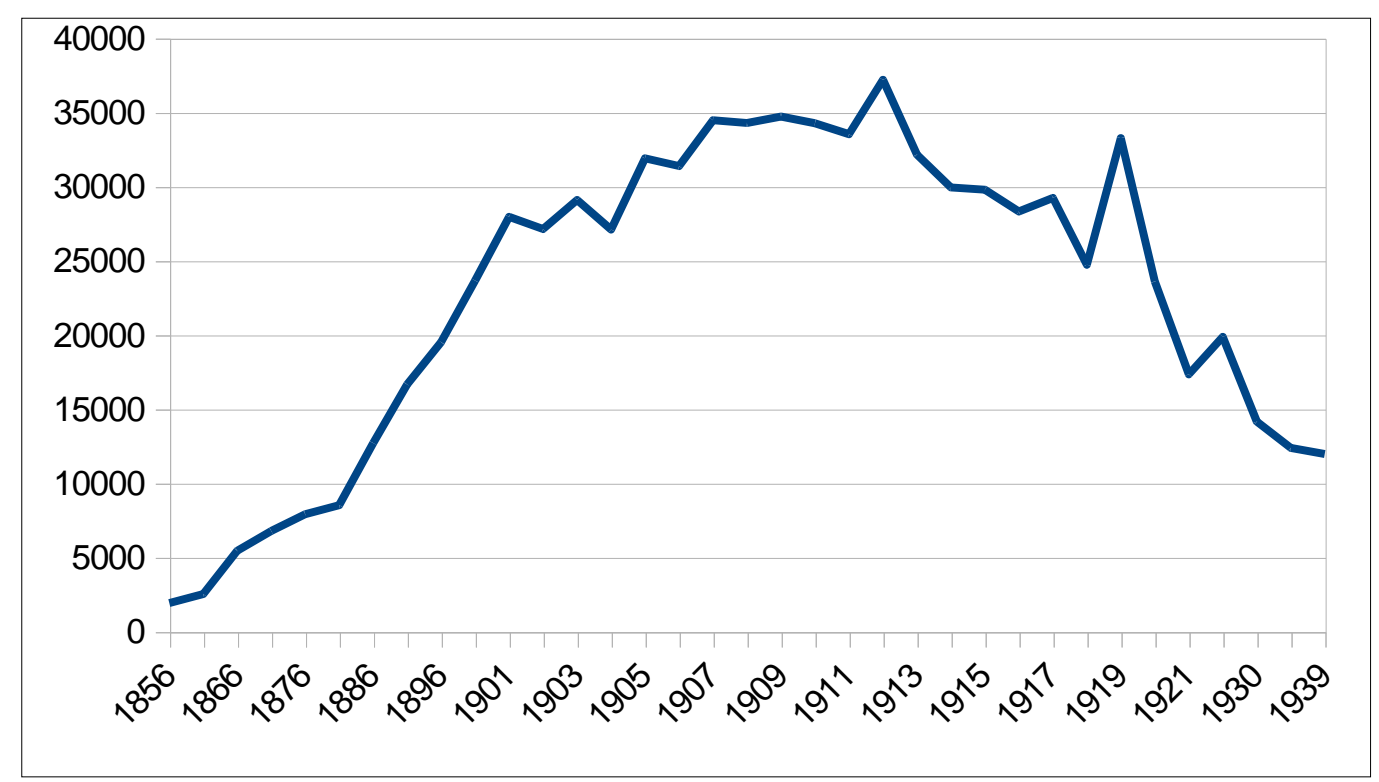

Fonte: Construído a partir do quadro 1.

Como se pode observar no quadro 1 e no gráfico 1 , a extração da borracha natural cresceu devido o avanço da indústria automobilística e calçadista no planeta, e com isso elevou-se os preços no mercado internacional. No Brasil, a maior reserva de seringueiras aptas a produção do látex se encontrava na Amazônia e isso fez com que o governo estimulasse a vinda de milhares de pessoas para trabalhar na extração do "ouro branco", chegando à soma de 300 mil trabalhadores, principalmente vindos nordeste. A partir do quadro 1, observa-se que em 1912 a produção de borracha alcançou o maior índice de produção, ou seja, 37.170 toneladas. Nesse sentido, Andrade (2001, p.18) diz:

[...] partir da metade do século XIX, posição internacional, devido à fabricação de pneus e câmaras de ar para automóveis, passando a ocupar o terceiro lugar na exportação, perdendo apenas para o café e o açúcar. Nesse período, milhares de pessoas, tanto do Brasil quando de outros países, foram atraídas para trabalhar a goma elástica, espalhando-se pelos seringais situados no alto dos cursos dos rios amazônicos.

Em contrapartida, a semente da seringueira foi levada para a Inglaterra em 1875 e as mudas foram transportadas para a ilha de Ceilão, e de lá se espalhou por todo o oriente. As seringueiras cultivadas produziram com maior rapidez e sua produção passou a entrar na escala internacional, inviabilizando a importação do Brasil. Dessa forma, no período de 19201945, cidades como Belém e Manaus, considerados como polos exportadores da borracha e referência na região, voltaram a viver de uma economia de subsistência dos produtos locais, 
da mesma forma, os trabalhadores extrativistas, sem informações, permaneceram na selva vivendo dos produtos da floresta.

O retorno da valorização da borracha brasileira somente volta acontecer devido à segunda guerra mundial, visto que a Malásia, a maior produtora de borracha, aliada do Japão, deixa de exportar para os Estados Unidos, e dessa forma os Estados Unidos são forçados a assinar um acordo com o Brasil, chamado Acordo de Washington, em 1942. Nesse acordo, os Estados Unidos se comprometeram a repassar recursos financeiros ao Brasil em troca da exclusividade da produção da borracha.

Marta (2018, p.395), ao analisar o acordo de Washington, destaca:

As tratativas pra o Acordo de Washington se iniciaram em 1939 e conclui-se em 1942. Por esse pacto, obrigava-se o Brasil a fornecer matérias-primas estratégicas, como borracha, em troca do financiamento de 100 milhões de dólares para construção da Companhia Siderúrgica Nacional (CSN), em Volta Redonda, no Rio de Janeiro, e parte do Plano de Industrialização Nacional. Podiam com isso implementar as duas ideias; o potencial econômico para uma colonização retomando-se a produção extrativista e a 'vocação' para a defesa das fronteiras nacionais, portanto, a colonização como uma localização estratégica.

Além disso, o Brasil cria o banco da Borracha, hoje Banco da Amazônia (BASA), para financiar investimentos na região como suporte da extração da borracha; também cria o batalhão da borracha, alistando jovens para trabalhar na extração do látex como soldados da borracha; e, ainda, permite que os Estados Unidos usassem as bases aéreas em Natal/RN, Recife/PE e Belém/PA como apoio.

Com o fim da guerra, esses soldados da borracha, foram abandonados pelo governo brasileiro, na selva, juntamente com os trabalhadores extrativistas, formando assim as chamadas populações tradicionais, vivendo da subsistência da floresta, constituindo famílias com povos indígenas da região.

\subsection{ESTRADA DE FERRO MADEIRA MAMORÉ}

Um capítulo referencial da história regional foi a construção da Estrada de Ferro Madeira Mamoré (E.F.M.M) no período de 1907-1912, como forma de pagamento do território boliviano conquistado pelos brasileiros, na chamada guerra do Acre, no final do século XIX. Território esse, disputado pela Bolívia, Peru e Brasil devido à extração da borracha. Em 1903, o Brasil celebra juntamente com o governo boliviano, o chamado acordo de Petrópolis, em que o Brasil se obrigava, como forma de pagamento do território ocupado pelos brasileiros, a construir uma ferrovia que possibilitasse o escoamento da produção 
boliviana para o oceano atlântico, visto que os rios Guaporé, Mamoré e Madeira são encachoeirados e não permitem a navegabilidade.

Figura 2 - Estrada de Ferro Madeira Mamoré

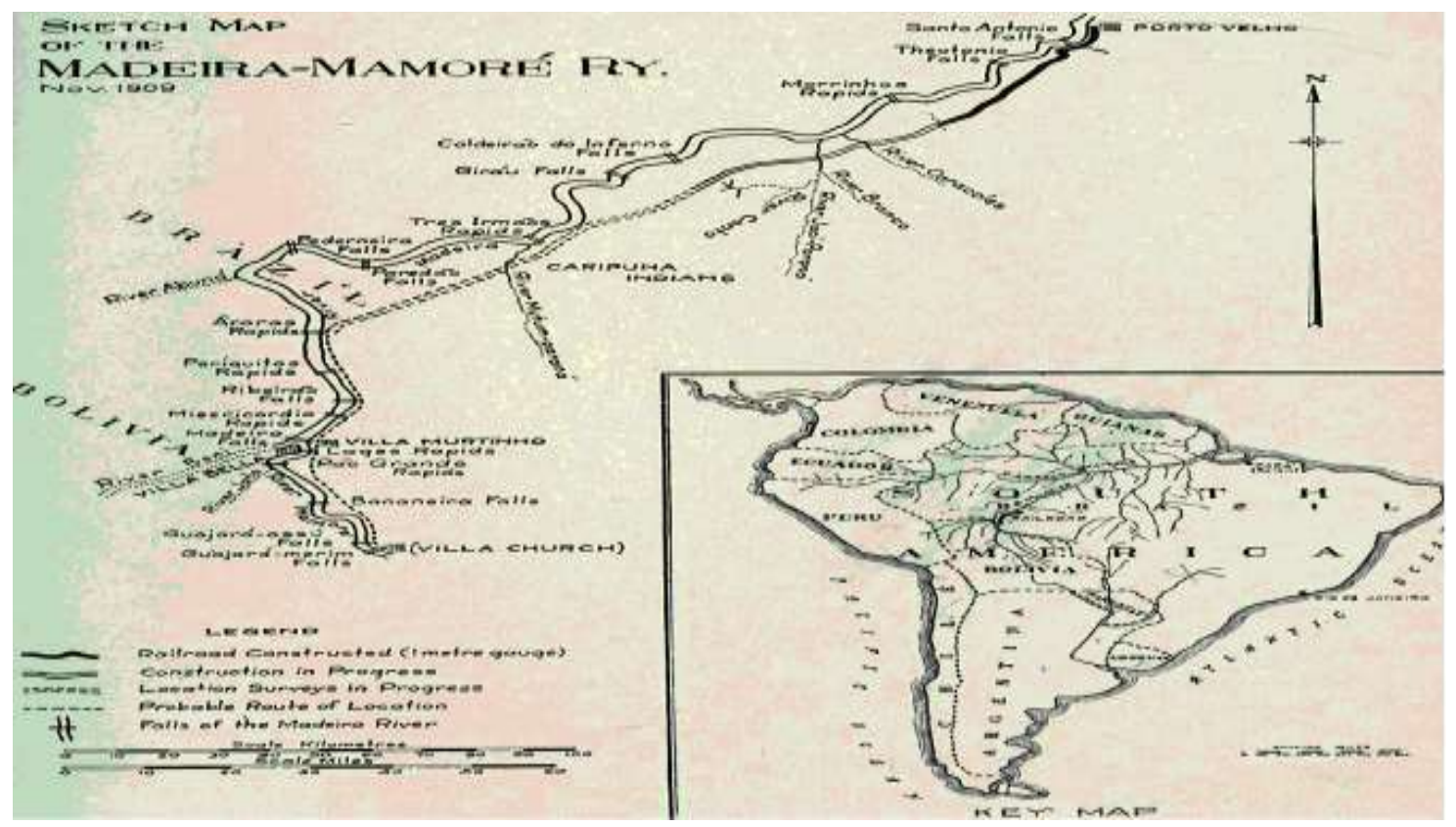

Fonte: https://efmm100anos.wordpress.com/2011/12/27/mapa-da-efmm-novembro-de-1909/

A ferrovia, que deveria ser internacional, foi construída somente no território brasileiro, ou seja, ligando Porto Velho a Guajará-Mirim, fronteira com a Bolívia, com uma distância de $366 \mathrm{~km}$, conforme se observa na figura 2. O objetivo da Bolívia com esse acordo era possibilitar exportar a borracha retirada no seu território, porém com a queda do preço da borracha, a ferrovia perde o sentido e fica transportando passageiros e a pequena produção local. Com o acordo de Acordo de Washington em 1942 e o retorno da produção da borracha na Amazônia, a ferrovia E.F.M.M. volta a ter um valor estratégico no transporte da goma elástica, bem como de passageiros da região. Porém com a construção de rodovias, em 1972, ela foi desativada.

Para Théry (2012, p.50):

Apesar de ter sido um fracasso comercial, a ferrovia não deixou de instalar, de forma definitiva, uma população fixa nas margens do Madeira e do Mamoré. Se a função da via no comércio continental foi muito pouca, seu papel na vida local foi importante. Ao longo dos seus trilhos, pequenos agricultores se instalaram e vendiam seus produtos nas cidades nascidas nas duas extremidades, Porto Velho e Guajará Mirim, que se tornaram a terceira e a quarta cidade, respectivamente, da Amazônia. As instalações da EFMM (Estrada de Ferro Madeira-Mamoré) proveram a essas cidades uma infraestrutura moderna (luz, ruas, água encanada, telefone). As escolas e os 
postos de saúde da EFMM foram durante muito tempo, junto com aqueles dos Salesianos, os únicos da região.

Com a queda do preço da borracha no mercado internacional, a economia proporcionada pela exportação da borrada, que ocupava o terceiro lugar no Produto Interno Bruto (PIB) perdendo apenas para o café e o açúcar, deixa a região em uma economia de subsistência. Por outro lado, segundo o autor, as comunidades de ribeirinhos e extrativistas se beneficiaram com a infraestrutura proporcionada pela ferrovia.

Outro marco da história da região foi a inauguração, em 1915, das linhas telegráficas pelo Marechal Cândido Mariano da Silva Rondon, ligando Cuiabá/MT à Vila de Santo Antônio do Madeira. Nesse período, contudo, a Vila de Santo Antônio pertencia ao estado do Mato Grosso, mas o objetivo da missão Rondon era interligar o oeste do Brasil.

A ocupação mais recente no então territorial federal de Rondônia foi sendo sistematicamente estimulada a partir da descoberta do minério de cassiterita em 1955, sendo intensificada na década de 1960. Através do Decreto-Lei no 1.106, de 16 de julho de 1970, o governo federal criou o Programa de Integração Nacional (PIN), que tinha como objetivo implementar obras de infraestrutura econômica e social no norte e no nordeste do país, visando à expansão da fronteira agrícola.

A partir do final do século XX, novas orientações passam a influenciar no processo ordenado da territorialização para a região. As abordagens têm como eixo a ECO/92 e contaram com financiamento do Banco Internacional para a Reconstrução e Desenvolvimento (BIRD) com a concepção do desenvolvimento sustentável.

Outro fator que deve ser levado em conta, e que constitui objeto deste estudo, é que o poder executivo estadual (quadriênio 2014-2018), com apoio do governo federal, elaborou o Plano de Desenvolvimento Estadual Sustentável de Rondônia (PDES-RO) para ser implantado de 2015 a 2030. No âmbito do projeto, criou-se o Observatório do Desenvolvimento Regional (ODR) que, em articulação com os diversos setores do estado, objetiva ser o elo de mediação entre o governo e a sociedade civil.

\subsection{RONDÔNIA UM TERRITÓRIO DE EXPERIMENTOS}

Rondônia tem servido como laboratório de grandes projetos de desenvolvimento regional. Essa análise pode ser observada a partir dos ciclos econômicos, como mencionados, e ocupação humana estimulada pelo governo federal a partir do final da década de 1960. Com a transformação do Território Federal em Estado em 1981, observou-se a implantação de projetos como: 1- o Programa de Desenvolvimento Integrado do Noroeste do Brasil 
(POLONOROESTE), objetivando a criação de estrutura para o funcionamento do Estado. O POLONOROESTE proporcionou a pavimentação da BR 364 em 1984, ligando o estado do Mato Grosso ao Acre, passando por Rondônia, e estimulou os primeiros assentamentos de colonos na região, criando os Núcleos Urbanos de Apoio Rural (NUAR); e 2- o Plano Agropecuário e Florestal de Rondônia (PLANAFLORO) que possibilitou a criação da Lei do Zoneamento Sócio-Econômico-Ecológico do Estado de Rondônia (ZSEE-RO), sendo o primeiro estado a ser zoneado no Brasil, contudo sem garantir a efetiva implantação desse projeto pelo governo. Outro projeto de grande impacto foi a construção, no período de 2008 a 2016, das 02 (duas) hidrelétricas do rio Madeira, Santo Antônio e Jirau, no município de Porto Velho.

Como consequência, pode-se destacar: a permissividade com as atividades minerais como os garimpos de ouro, de cassiterita e diamante; a construção de estradas na Amazônia para incentivar a migração teve como consequência o desmatamento exacerbado; 0 financiamento pelo Banco da Amazônia (BASA) promoveu a aceleração da agropecuária na região; a migração populacional incentivada influenciou no processo do desmatamento, entre outras questões.

\subsection{RONDÔNIA: UMA FRONTEIRA RECENTE}

A migração acelerada para a região norte do Brasil foi estimulada pelos governos militares a partir do final da década de 1960, se intensificando nas décadas de 1970/80, visando ocupar a fronteira na região norte do país.

Para possibilitar a compreensão do estado de Rondônia, deve-se levar em conta os projetos de ocupação da Amazônia por meio do Programa de Integração Nacional (PIN), responsável pela criação de infraestrutura na região. Nesse período, foram criadas a Superintendência do Desenvolvimento do Nordeste (SUDENE) e a Superintendência do Desenvolvimento da Amazônia (SUDAM), objetivando a concessão de incentivos fiscais a empresas que quisessem investir tanto na região nordeste quanto na região norte. Também foi criado, nesse período, o Instituto Nacional de Colonização e Reforma Agrária (INCRA), responsável pela demarcação das terras devolutas, proporcionando, assim, os assentamentos dos migrantes que vinham trabalhar na lavoura, estimulados pelo governo.

Soares (2015, p.80), ao analisar a ocupação da Amazônia no período do governo militar do General Emilio Garrastazu Médici, destaca:

E para ocupar a região era preciso contingentes populacionais equivalentes à dimensão de seu território, estando também disponíveis a um trabalho que dinamizasse a economia local. Mas para que essas pessoas pudessem chegar 
à Amazônia era necessário um esquema de transporte que facilitasse a entrada na região e tornasse exequível o projeto de ocupação. Independente da seca, a realização dessas premissas exigia a execução dos objetivos e obras listadas no Programa de Integração Nacional, como a construção da Transamazônica, o deslocamento dos trabalhadores rurais e o programa de colonização às margens das rodovias.

Houve a construção de rodovias como: a Transamazônica ou BR 230 tinha como objetivo ligar o nordeste brasileiro ao sul da Amazônia, ou seja, de Cabedelo/PB a Benjamim Constant/AM, porém a construção se encerrou na cidade de Lábrea/AM; a construção da BR 364 ligando Cuiabá/MT - Porto Velho/RO - Rio Branco/AC; a construção da BR 363 ligando Cuiabá/MT - Santarém/PA; a construção da BR 319 ligando Manaus/AM - Porto Velho/RO; e a construção da BR 174 ligando Manaus/AM - Boa Vista/RR. Essas rodovias faziam parte da estratégia para possibilitar a migração para essas regiões, principalmente das populações mais empobrecidas do Brasil, como as acometidas pela seca do nordeste na década de 1970.

\section{Figura 3 - Rodovias federais na Amazônia}

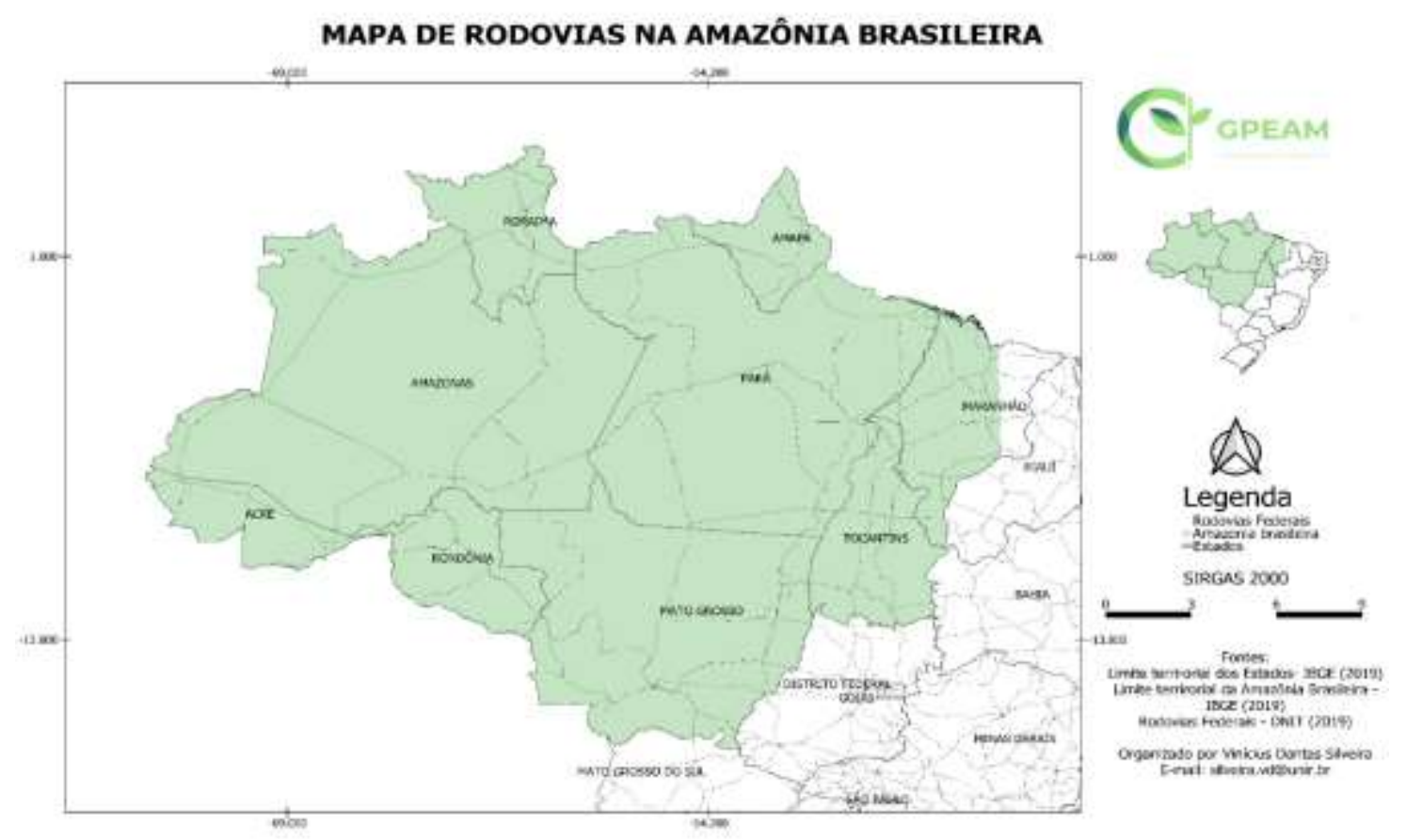

Fonte: Limite territorial da Amazônia Brasileira - IBGE (2019) /Rodovias Federais - DNIT (2019). Organizado por Vinícius Dantas Silveira

O crescimento populacional de Rondônia, segundo o Relatório n. o 8073-BR (1992, p.18) foi: “de 113.000 em 1970 para 491.000 habitantes em 1980 e para 905.000 em 1985 (i.e. taxa média de crescimento anual de $16 \%$ e $13 \%$, respectivamente, para os períodos de 1970/80 e 1980/85). Em 1988, a população estadual tinha alcançado quase 1.4 milhões de 
habitantes". Conforme a estimativa do IBGE (2020), a população de Rondônia é de 1.796.460 pessoas.

A população que migrou para Rondônia veio estimulada de várias regiões brasileiras, à época, para trabalhar como suporte governamental, tanto nos serviços públicos urbanos quanto na orientação do cultivo da terra, e principalmente para trabalhar na terra nos mais variados tipos de lavouras e atividades rurais.

Com relação ao processo migratório de colonos que vieram estimulados pelo governo, a partir da década das décadas de 1960/1970, Théry (2012, p.142), vai destacar os projetos de colonização ordenados pelo governo:

Portanto, pode-se distinguir três tipos:

- a colonização pública federal, a cargo do INCRA, e que abrange três PIC (Projetos Integrados de Colonização);

- a colonização pública territorial da qual trata a Secretaria de Agricultura, Economia e Colonização do governo do Território;

- a colonização privada.

O primeiro tipo não tem relação com os dois outros. No primeiro caso, são vários milhares de famílias bem acompanhadas. Nos dois outros tipos, algumas centenas de casos praticamente deixados à própria sorte e que, uma vez no seu lote, mal se distinguem dos posseiros.

Verifica-se que existiram três modelos de colonização implantados, nesse período, no território, ou seja, três Projetos Integrados de Colonização (PIC) coordenados pelo Instituto de Colonização e Reforma Agrária (INCRA), sendo a colonização pública, coordenada pela Secretaria de Agricultura, Economia e Colonização (SAEC) do governo do Território, e a colonização privada, credenciada pelo governo para estimular a reforma agrária. Devido à grande procura de terras, estimulada pelo governo como: Rondônia, o novo "Eldorado do Brasil”, o INCRA, criou o Projeto de Assentamento Rápido (PAR) em que os módulos de terra passaram para 50 hectares. Sem infraestrutura, como estradas, os colonos só tinham acesso aos lotes por meio de picadas no meio da mata.

Outro fator a ser destacado é que o incentivo do governo era para ocupar e desmatar a região, estimulando os migrantes a pensarem que existia um espaço vazio a ser ocupado, não considerando as populações residentes na região como os povos originários (indígenas) e as populações tradicionais (extrativistas, quilombolas e pescadores), acarretando em conflitos entre migrantes - garimpeiros, madeireiros, fazendeiros - estimulados, que passavam a desmatar as áreas, sem levar em conta a história dos moradores ali residentes. 
Quadro 2 - Projetos de colonização

\begin{tabular}{|l|c|c|c|}
\hline & Número de parcelas & Superfície das parcelas & Localização \\
\hline Projetos de colonização federal & \multicolumn{2}{|l|}{} & \\
\hline Ouro Preto & 4000 & 100 & BR 364 km 330 \\
\hline Sidney Girão & 500 & 100 & BR 319 km 70 \\
\hline Gy-Paraná & 900 & 100 & BR 364 km 540 \\
\hline Colônias agrícolas do Território & & & BR 364 km 25 \\
\hline Candeias & 150 & 25 & BR 364 km 12 \\
\hline Periquitos & 150 & 25 & BR 364 km 12 \\
\hline 18 de Setembro & 150 & 25 & BR 364 km 8 \\
\hline Areia Branca & 150 & 25 & BR 364 km 25 \\
\hline Paulo Leal & 150 & 25 & BR 364 km 30 \\
\hline Iata & 400 & 25 & Vila de Rondônia \\
\hline Colônias privadas & & & Pariável \\
\hline Calama AS & 600 & $500 / 2000$ & \\
\hline Espigão do Oeste & 450 & & \\
\hline
\end{tabular}

Fonte: Théry 2012, p. 142).

O Quadro 2 demonstra os principais projetos de colonização fundiária organizados tanto pelo governo quanto por empresas privadas, licenciadas pelo Estado. Os lotes dos Projetos Integrados de Colonização (PIC) variavam entre 100 e 200 hectares; os lotes de 100 hectares eram destinados às famílias que iriam exercer uma agricultura tradicional e os lotes de 200 hectares seriam para gado.

Ao analisar a migração na década de 1970, Marta (2018, p.408) expõe:

Em 1979, segundo o Ministério do Interior à época, as migrações internas entre estados indicavam que Rondônia era região em que a população vinda do Norte e Nordeste representava 4,2\%; 18,4\% vinham do Sudeste; $34,0 \%$ do Sul e 43,4\% do próprio Centro-Oeste.

Como se observa, nesse período havia uma intensa migração para o oeste, estimulado pela ocupação do território, além da busca de oportunidade em adquirir terras como meio para a comercialização.

\subsection{POLONOROESTE}

A questão socioeconômica gerada pela massa migratória na região e a falta de um planejamento estratégico governamental que pudesse ordenar a ocupação do solo pelos migrantes, fizeram com que, em 1980, fosse lançado o Programa de Desenvolvimento Integrado do Noroeste do Brasil (POLONOROESTE) pelo governo federal, contando com financiamento do Banco Mundial. Segundo o Relatório n. o 8073-BR (1992, p.20), “O objetivo 
central do programa seria a conclusão e asfaltamento da principal rodovia federal na Região Noroeste (BR-364) entre Cuiabá (capital do Mato Grosso) e Porto Velho (capital de Rondônia)". Além da pavimentação da BR, o programa estimulou os primeiros assentamentos de colonos na região.

Analisando os investimentos do Banco Mundial ao governo brasileiro, Oliveira (1994, p.10) destaca:

O programa POLONOROESTE foi financiado por cinco empréstimos do Banco Mundial, os quais incluem três que apoiaram principalmente a agricultura, o desenvolvimento rural e o meio ambiente. Em 1981 foram aprovados 65 milhões de dólares para o desenvolvimento da agricultura e o projeto de proteção ao meio-ambiente. Esse empréstimo ficou conhecido como Noroeste

Outros 13 milhões de dólares foram aprovados adicionalmente no ano de 1981, com o objetivo de melhorar as condições de saúde dos colonos assentados em Rondônia e Mato Grosso.

Para a pavimentação da estrada federal BR-364 que liga Cuiabá a Porto Velho, também no ano de 1981, foram liberados 240 milhões de dólares. Com esses recursos deveriam ser construídas outras estradas alimentadoras daquela rodovia.

O projeto Noroeste II, da ordem de 26,4 milhões de dólares, foi aprovado no ano de 1982 e estava destinado ao desenvolvimento da agricultura e proteção do meio ambiente no Estado do Mato Grosso.

O projeto Noroeste IIl, da ordem de 65,2 milhões de dólares, foi aprovado no ano de 1983. Destinava-se a apoiar os assentamentos, ou seja, apoiar a colonização das terras não ocupadas em Rondônia.

O Banco Mundial através do Programa de Ações Especiais para o Brasil PAE, ainda liberou 22,8 milhões de dólares de financiamento suplementar para o Projeto Noroeste I no ano de 1983.

De acordo com o relatório: “Análise Crítica da Implementação do Plano Agropecuário e Florestal de Rondônia um Ano Após o Acordo para sua Reformulação: PLANAFLORO um ano depois", realizado pelos Amigos da Terra - Programa Amazônia, e Oxfam, publicado em 1997 (p.10), as críticas ao POLONOROESTE foram:

Em setembro de 1984, a pavimentação da BR-364 entre Cuiabá e Porto Velho foi inaugurada antes do previsto pelo então Presidente da República, João Batista Figueiredo. No entanto, já era evidente nessa época que a execução do POLONOROESTE estava sendo acompanhada por sérios problemas, incluindo um grande aumento no fluxo de migrantes em busca de terras e emprego, taxas alarmantes de desmatamento, desistência de pequenos agricultores em projetos de colonização (associada à concentração fundiária e à expansão da pecuária como uso predominante da terra), exploração predatória de madeira, invasões de áreas indígenas e outras unidade de conservação, crescimento desordenado de garimpos e áreas urbanas, etc. 
Devido às denúncias de desvios das finalidades, como mencionado, o POLONOROESTE tornou-se o foco de uma campanha de ONGs, tanto nacionais quanto internacionais que atuavam na região. Essas organizações exigiram mudanças nos procedimentos adotados pelos bancos multilaterais que o financiavam. Dessa forma, em meados de 1985, após avaliação do meio-termo (órgão do Banco Mundial) foram suspensos temporariamente o desembolso dos recursos.

Por outro lado, deve-se registrar que o Programa proporcionou a construção de 23 Núcleos Urbanos de Apoio Rural (NUARES) que aos poucos se transformaram em municípios; criou escolas, hospitais e postos de saúde, além de possibilitar estradas para escoamento da produção agrícola.

\subsection{PLANAFLORO}

\subsection{1 $1^{\text {a }}$ Aproximação do Zoneamento Socioeconômico e Ecológico}

O governo de Rondônia, visando corrigir os rumos adotados pelo Programa de Desenvolvimento Integrado para o Noroeste do Brasil (POLONOROESTE), criou, por meio do Decreto Estadual No 3782 de 14 de junho de 1988, a $1^{\text {a }}$ Aproximação do Zoneamento Sócio-Econômico-Ecológico, ratificado pela Lei Complementar $\mathrm{n}^{\circ}$ 052, de 20 de dezembro de 1991, que serviu como base para implantação do Plano Agropecuário e Florestal de Rondônia (PLANAFLORO).

A chamada primeira aproximação tinha com orientação a implantação do zoneamento, com base na concepção da sustentabilidade. Nessa perspectiva, o estado foi dividido nas chamadas zonas sócio-econômico-ecológico. Conforme o Decreto $\mathrm{n}^{\mathrm{o}} 3782$, descrito no seu artigo $5^{\circ}$, o Zoneamento tinha o seguinte objetivo:

Art. $5^{\circ}$ - O Zoneamento Sócio-Econômico-Ecológico de Rondônia é um instrumento de planejamento do uso da terra, que visa disciplinar a ocupação espacial, em função da capacidade de oferta dos recursos ambientais de cada zona, consoante sua caracterização específica de vocação e uso atual, onde as ações, econômicas ou não, impliquem na preservação de ecossistemas frágeis e belezas cênicas naturais; conservação de ecossistemas e reposição florestal, com espécies nativas, objetivando minimizar os impactos ambientais, maximizar a eficiência sócio-econômico-ecológica dos recursos naturais, manter a integridade física das áreas indígenas e preservar a cultura aborígene.

$\S 1^{\circ}$ - O Zoneamento Sócio-Econômico-Ecológico de Rondônia define 06 (seis) zonas, em função de seus ambientes econômico-ecológicos peculiares e características sociais específicas.

$\S 2^{\circ}$ - As Zonas estão delimitadas em função de suas potencialidades naturais, uso atual, estrutura fundiária e aspectos sócio-econômico-culturais. 
Nessa perspectiva, com base no Decreto mencionado, pode se observar o mapa, na figura 4, com áreas demarcadas. No quadro 3, abaixo, pode se verificar a disposição por áreas, de forma sistematizada, e as potencialidades percebidas em relação ao estado de Rondônia.

\section{Figura 4 - $1^{a}$ Aproximação do Zoneamento Sócio-econômico-ecológico do Estado de}

\section{Rondônia}

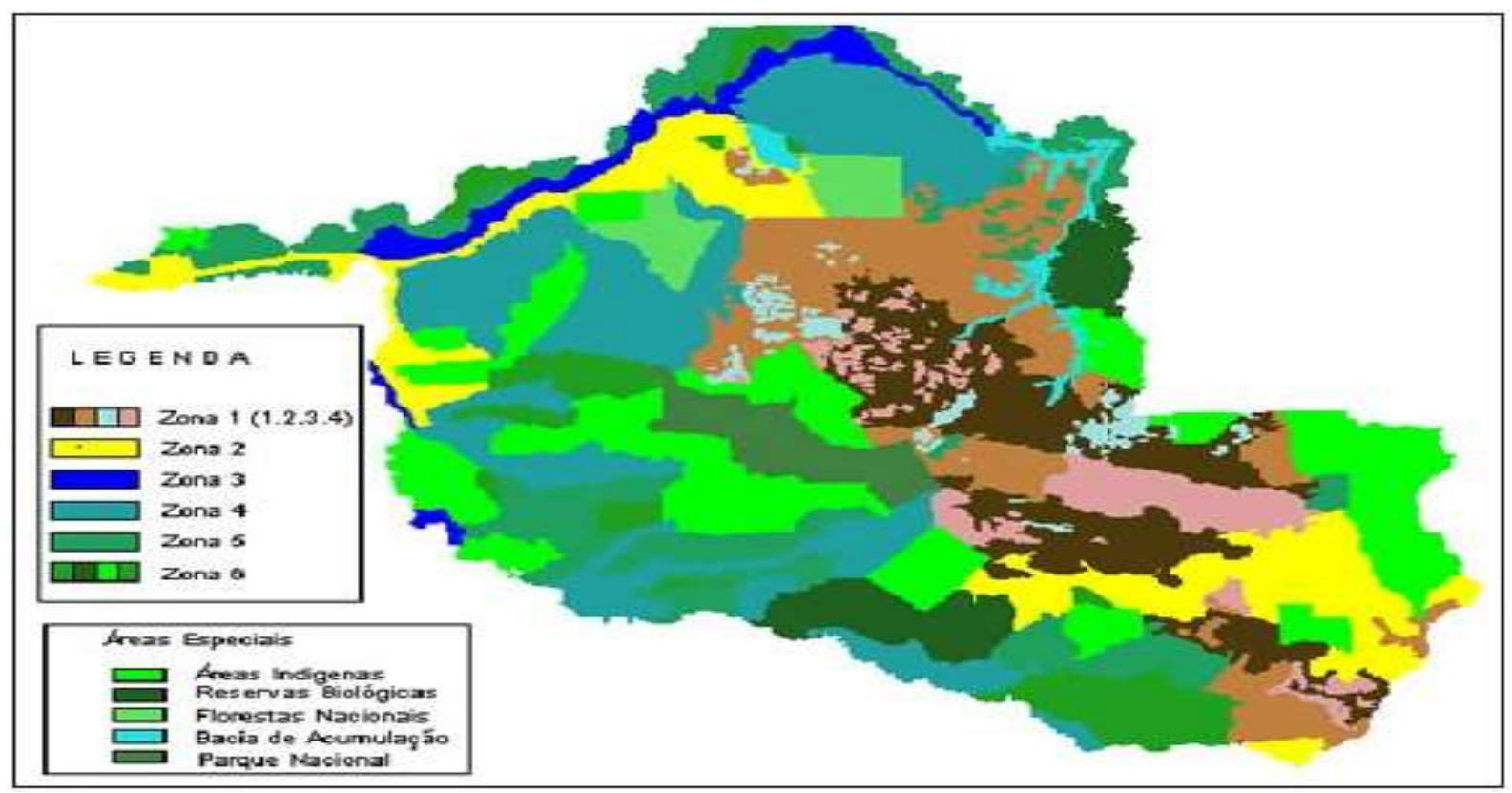

Fonte: sepog. ro.gov.br

Quadro 3 - Divisão territorial da $1^{a}$ Aproximação do Zoneamento Sócio-econômico-ecológico do Estado de Rondônia (ZSEE-RO)

\begin{tabular}{|c|c|c|c|c|}
\hline Zona & Destinação & Finalidade & Área (há) & $(\%)$ \\
\hline 1 & $\begin{array}{c}\text { Intensificação da Exploração } \\
\text { Agropecuária }\end{array}$ & $\begin{array}{l}\text { Ordenamento e recuperação das } \\
\text { atividades agrícolas, pecuária e } \\
\text { agroflorestais. }\end{array}$ & 6.195 .000 & 28,0 \\
\hline 2 & $\begin{array}{l}\text { Pequenos produtores em } \\
\text { coletividade }\end{array}$ & $\begin{array}{l}\text { Recuperação e desenvolvimento da } \\
\text { atividade agropecuária e de } \\
\text { agricultura consorciada com culturas } \\
\text { permanentes. }\end{array}$ & 3.015 .000 & 13,6 \\
\hline 3 & Ribeirinha & $\begin{array}{l}\text { Aproveitamento de várzeas e terras } \\
\text { firmes marginais aos rios, } \\
\text { desenvolvendo } \\
\text { agroflorestais e pesqueiras. }\end{array}$ & 589.000 & 2,7 \\
\hline 4 & Extrativista & $\begin{array}{l}\text { Ordenamento e desenvolvimento do } \\
\text { extrativismo vegetal de castanha, } \\
\text { gomas, óleos, frutos e raízes } \\
\text { exploráveis. }\end{array}$ & 3.500 .000 & 15,8 \\
\hline 5 & Manejo Florestal & $\begin{array}{l}\text { Importante potencial madeireiro para } \\
\text { extração em escala comercial }\end{array}$ & 2.435 .000 & 15,8 \\
\hline 6 & Observação e Preservação & $\begin{array}{l}\text { Garantir a manutenção dos } \\
\text { ecossistemas e o equilíbrio ecológico. }\end{array}$ & 6.400 .000 & 28,9 \\
\hline
\end{tabular}

Fonte: Governo de Rondônia, 2010 
Andrade (2001, p.52), ao analisar os investimentos do Banco Mundial ao PLANAFLORO, destaca:

Esse Programa contou com um orçamento de US\$228,9 milhões, dos quais US\$ 167 milhões eram oriundos de um empréstimo do Banco Mundial, e o restante financiado pelos governos Estadual e Federal, ficando assim dividida sua aplicação: U\$ 68,4 milhões para conservação, manejo e proteção ambiental; U\$ 81,4 milhões para desenvolvimento agro-florestal; U\$ 71,5 milhões para infra-estrutura sócio-econômica e de serviços, e 11,2 milhões para administração, monitoramento e avaliação. Os principais beneficiários seriam 52.000 famílias de pequenos agricultores de baixa renda, 5.000 a 6.000 índios, 2.400 famílias de seringueiros, 900 famílias de pescadores e de outros habitantes ribeirinhos.

As aplicações dos investimentos foram contestadas por um grupo de 25 (vinte e cinco) Organizações Não-Governamentais, sob a coordenação pelo Fórum das ONGs e Movimentos Sociais que atuam em Rondônia. Conforme Smeraldi (1995, p.4) essas entidades representavam "os pequenos agricultores, populações extrativistas, comunidades indígenas, ambientalistas, educadores, pesquisadores, entidades de assessoria a movimentos populares e defesa dos direitos humanos, entidades de cunho filantrópico e religioso".

Nesse sentido Smeraldi (1995, p.4) as denúncias se fundamentaram entre outras questões:

Não obstante a importância dos objetivos gerais do PLANAFLORO, a execução prática do projeto, desde os primeiros desembolsos do Banco Mundial em junho de 1993, tem sido prejudicada por uma série de entraves, causados, em boa parte, por omissões do próprio Banco, associadas ao não cumprimento dos contratos de projeto e de empréstimo assinados com os governos federal e estadual, assim como de suas próprias normas e políticas setoriais sobre Política Florestal, Áreas de Vida Silvestre, Populações Indígenas, Envolvimento de ONGs, Preparação de Projetos, Supervisão, Monitoramento e Avaliação, Licitação e Suspensão de Desembolsos.

O documento salienta questões de negligência do Banco Mundial, bem como denuncia as instituições brasileiras, como a atuação do "INCRA em Rondônia tem servido como 'catalizador', iniciando uma cadeia de intervenções de outros órgãos governamentais que acabam legitimando e incentivando a ocupação desordenada do espaço e a utilização indiscriminada de recursos naturais" (OC. 1995, p. 14).

A partir das denúncias elencadas, o Banco Mundial adotou providências junto ao governo de Rondônia, e em conjunto com a sociedade civil mediada pelo Fórum das ONGs, retomou os trabalhos. Desse trabalho, que contou com maior rigor nas análises, resultou o documento chamado $2^{\mathrm{a}}$ aproximação do Zoneamento Sócio-Econômico-Ecológico aprovado e transformado em Lei. 


\subsubsection{2a Aproximação do Zoneamento Socioeconômico e Ecológico}

A $2^{\text {a }}$ aproximação do Zoneamento Socioeconômico e Ecológico do Estado de Rondônia passou ser a principal referência para o planejamento da ocupação humana na região, bem como no direcionamento de investimento regional, tendo como base a concepção do desenvolvimento sustentável. Esse planejamento foi aprovado pela Lei Complementar $n^{\circ}$ 233, de 06 de junho de 2000. Posteriormente alterada pela Lei Complementar $\mathrm{n}^{\circ} 312$, de 06 de maio de 2005, acrescentando e revogando dispositivos.

De acordo com o governo de Rondônia em documento denominado "21 anos zoneamento socioeconômico ecológico do Estado de Rondônia: planejamento para o desenvolvimento sustentável e proteção ambiental" a segunda aproximação refere-se à atualização da geologia, geomorfologia, climatologia, recursos hídricos superficiais, pedologia, vegetação, fauna, uso e ocupação do solo, situação e estrutura fundiária, sócioeconomia e aptidão agrícola, vulnerabilidade ambiental, sistemas naturais e socioeconômicos e zoneamento, e ainda destaca, Rondônia (2010, p.11):

O principal objetivo do zoneamento Socioeconômico-Ecológico do Estado de Rondônia é orientar a implementação de medidas e elevação do padrão socioeconômico das populações, por meio de ações que levem em conta as potencialidades, as restrições de uso e a proteção dos recursos naturais, permitindo que se realize o pleno desenvolvimento das funções sociais e do bem-estar de todos, de forma sustentável.

Conforme o documento "PLANAFLORO: zoneamento socioeconômico-ecológico de Rondônia" Rondônia (2000, p.20), antes de ser transformado em Lei, o projeto foi amplamente discutido com todos os seguimentos da sociedade em audiências públicas.

Foram realizadas 60 (sessenta) reuniões, com a participação de cerca de 2.100 pessoas, em todos os municípios do Estado de Rondônia, envolvendo associações de agricultores, sindicatos, lideranças político municipais, técnico, onde foram apresentadas informações sobre a primeira aproximação e os estudos a serem realizados para a elaboração da Segunda Aproximação.

O resultado dos trabalhos gerou a aprovação do Zoneamento SocioeconômicoEcológico do Estado de Rondônia (ZSEE-RO), sendo o primeiro estado da federação a ter reconhecimento do Ministério do Meio Ambiente, Ministério da Agricultura e pelo Conselho Nacional do Meio Ambiente (CONAMA).

Para Carvalho (2002, p. 12), o objetivo estratégico do ZSEE-RO, foi: 
do Estado de Rondônia de maneira a que a sociedade no seu conjunto pudesse obter um convívio sustentado com o ambiente frágil da Bacia Amazônica.

A elaboração do ZSEE-RO contou com participação efetiva dos órgãos governamentais, conselhos de classes, instituições de pesquisas, sociedade civil através de associações de classes, sindicatos, organizações não governamentais, visando à organização, acompanhamento e elaboração do projeto do PLANAFLORO. Nesse contexto, ao analisar a participação da sociedade civil, destaca Carvalho:

Pode-se, contudo, adiantar que o complexo processo representado pela presença e participação de organizações não-governamentais, sindicais e de movimentos sociais que atuavam em Rondônia no Planafloro constituiu-se, durante toda a década de 90, numa das mais importantes referências nacionais de disputa pelo compartilhamento do poder pela participação social na gestão de projetos públicos, seja pela ousadia das suas ações e pela capacidade de defesa dos interesses que representavam seja pela mobilização social que mantiveram constante até julho de 2001 quando se deu a dissolução política do Fórum. (CARVALHO, 2002, p.22)

Observa-se que a sociedade civil, naquele momento histórico, através do Fórum das ONGs, agiu de forma coordenada e efetiva na disputa pela hegemonia visando à construção do documento final do PLANAFLORO. No conjunto das organizações, contou com representatividade tanto das populações originárias (indígenas de diversas etnias) quanto da sociedade tradicional regional (extrativistas, quilombolas e ribeirinhos), além da participação de organizações internacionais.

O fórum das ONGs, portanto, configurou-se como uma entidade mediadora dos interesses da sociedade civil junto ao governo do estado e do Banco Mundial, contribuindo tanto na elaboração das propostas, quanto realizando denúncias sobre desvios dos objetivos do programa. Deve-se ressaltar, portanto, que o resultado desse efetivo trabalho, resultou na definição por consenso na legislação que definiu a $2^{\mathrm{a}}$ Aproximação do Zoneamento SócioEconômico-Ecológico de Rondônia (ZSEE-RO) como o norte a ser desenvolvido pelo estado e pela sociedade em geral. 
Figura 5 - $2^{a}$ Aproximação do Zoneamento Sócio-Econômico-Ecológico de Rondônia (ZSEE-RO)

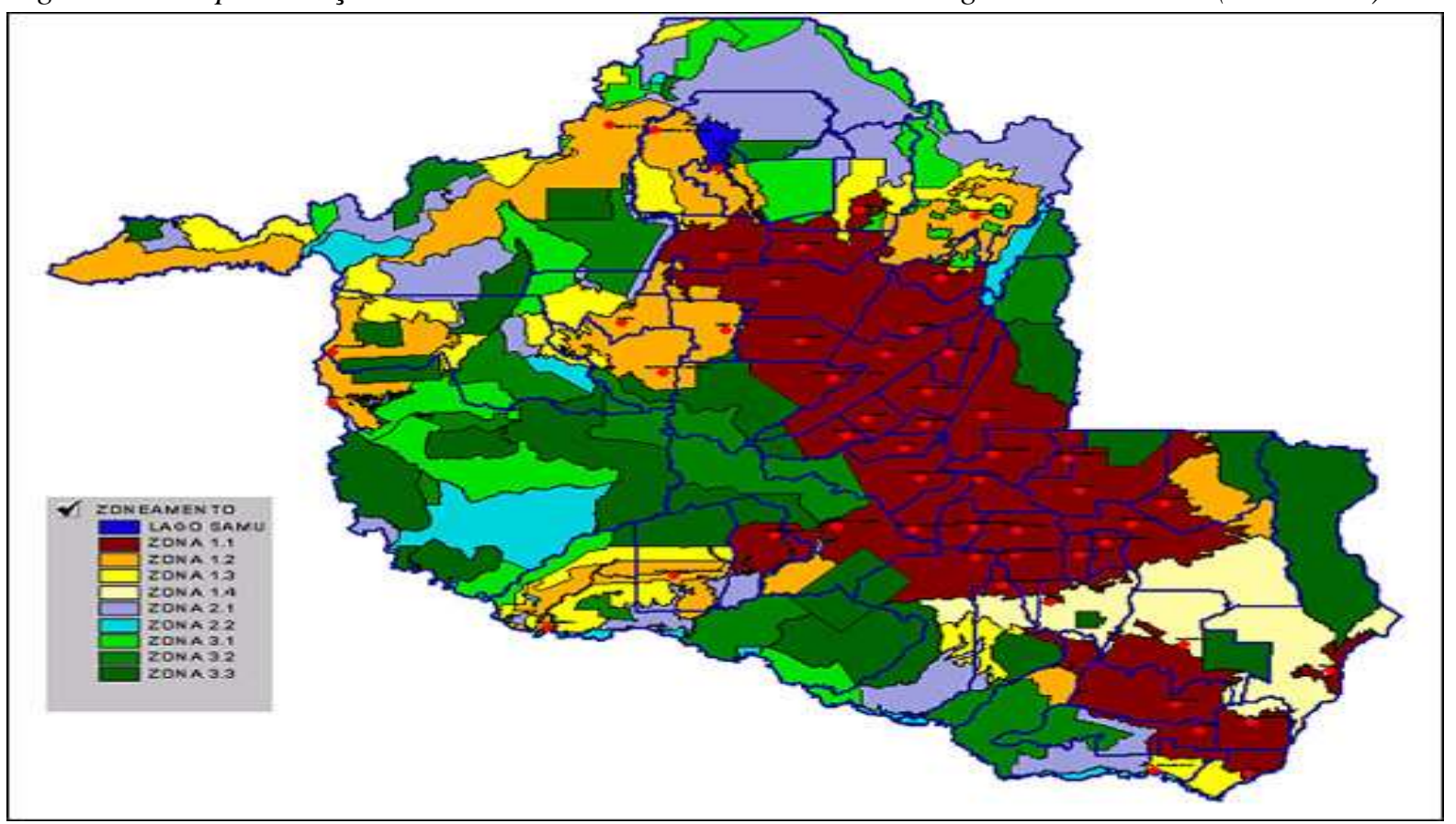

Fonte: Governo de Rondônia (2000)

Quadro 4 - Resumo da Lei Complementar no 233 de 06 de junho de 2000 (2 ${ }^{a}$ Aproximação do ZSEE-RO)

\begin{tabular}{|l|l|}
\hline Zona & \multicolumn{1}{|c|}{ POTENCIALIDADE/DESTINAÇÃO } \\
& $\begin{array}{l}\text { Art. } 7^{\circ} \text { - A Zona 1, composta de áreas de uso agropecuário, abrange 120.310,48 km2, equivalentes a 50,45\% da } \\
\text { área total do Estado. } \\
\text { § } 1^{\circ} \text { - As terras da Zona 1, utilizadas para diferentes fins, principalmente agropecuário, possuem graus } \\
\text { variáveis de ocupação e de vulnerabilidade ambiental, que caracterizam diferentes subzonas. } \\
\text { § 2o - A Zona 1 obedecerá às seguintes diretrizes: } \\
\text { I - como diretriz geral, deve ser estimulado o desenvolvimento das atividades primárias em áreas já } \\
\text { desmatadas ou habitadas, com práticas adequadas e manejo no uso dos recursos naturais, especialmente do } \\
\text { solo, de forma a maximizar os custos de oportunidade representados pelo valor da floresta; } \\
\text { II - estímulo ao manejo sustentado dos recursos florestais e, em particular, o reflorestamento e a recuperação } \\
\text { de áreas degradadas, de preservação permanente e da reserva legal, incluindo o aproveitamento alternativo da } \\
\text { capoeira; } \\
\text { III - aplicação de políticas públicas compensatórias, visando à manutenção dos recursos florestais } \\
\text { remanescentes, evitando a sua conversão para sistemas agropecuários extensivos; } \\
\text { IV - condicionamento das diretrizes de uso das Subzonas para obras de infra-estrutura, em particular com } \\
\text { referência a estradas. }\end{array}$ \\
\hline Zona 2 & $\begin{array}{l}\text { Art. } 8^{\circ} \text { - A Zona 2 é composta de áreas de uso especial, abrangendo 34.834,42 km2, equivalentes a 14,60\% da } \\
\text { área total do Estado, destinada à conservação dos recursos naturais, passíveis de uso sob manejo sustentável. }\end{array}$ \\
\hline Zona 3 & $\begin{array}{l}\text { Art. 9o - A Zona 3 é composta de áreas institucionais, constituídas por aquelas protegidas de uso restrito } \\
\text { instituídas pela União, Estado e Municípios, equivalentes a 34,95 \% da área total do Estado. }\end{array}$ \\
\hline
\end{tabular}

Fonte: Lei Complementar Estadual no 233/2000.

Conforme pode ser observado no quadro 4, a demarcação do estado de Rondônia ficou configurada em 03 (três) zonas ou regiões, com objetivo de determinar os rumos a serem seguidos de forma estratégica pelo Estado: zona 1- destinada a agropecuário, com um 
percentual de 50,45\% da área do Estado; zona 2- destinada a conservação dos recursos naturais, passíveis de uso sob manejo sustentável, com um percentual de 14,60 \% da área total do Estado; e a zona 3- destinada a proteção de uso restrito instituído pela União, estado e municípios, equivalentes a 34,95 \% da área total do Estado.

Quadro 5 - Síntese do zoneamento

\begin{tabular}{|c|c|c|c|c|c|c|c|}
\hline \multirow[b]{2}{*}{ ZONA } & \multirow[b]{2}{*}{ Área } & \multirow[b]{2}{*}{$\%$} & \multirow[b]{2}{*}{$\%$} & \multicolumn{2}{|c|}{ Área preservada } & \multicolumn{2}{|c|}{ Área exploração } \\
\hline & & & & & $\%$ & & $\%$ \\
\hline & Hectares & Estado & Reserva & Hectares & Estado & Hectares & Estado \\
\hline 1.1 & $6.141 .734,87$ & 25,75 & 20 & $1.228 .346,97$ & 5,15 & $4.913 .387,90$ & 20,60 \\
\hline 1.2 & $3.066 .401,19$ & 12,96 & 40 & $1.226 .560,47$ & 5,14 & $1.839 .840,71$ & 7,72 \\
\hline 1.3 & $1.482 .380,61$ & 6,22 & 70 & $1.037 .666,42$ & 4,35 & $444.714,18$ & 1,87 \\
\hline 1.4 & $1.340 .531,12$ & 5,62 & 80 & & & & \\
\hline $\begin{array}{l}\text { Sub- } \\
\text { total }\end{array}$ & 12.031.047,79 & 50,45 & & 4.564.998,77 & 19,14 & $7.466 .049,02$ & 31,31 \\
\hline 2.1 & $2.565 .336,50$ & 10,75 & & & & & \\
\hline 2.2 & $918.105,54$ & 3,85 & & & & & \\
\hline $\begin{array}{l}\text { Sub- } \\
\text { total }\end{array}$ & $3.483 .442,04$ & 14,60 & & $3.483 .442,04$ & 14,60 & & \\
\hline 3.1 & $1.808 .129,12$ & 7,58 & & & & & \\
\hline 3.2 & $1.375 .250,04$ & 9,96 & & & & & \\
\hline 3.3 & $4.153 .410,90$ & 17,41 & & & & & \\
\hline $\begin{array}{l}\text { Sub- } \\
\text { total }\end{array}$ & $8.336 .790,07$ & 34,95 & & $8.336 .790,07$ & 34,95 & & \\
\hline Total & 23.851.279,90 & 100 & & $16.385 .230,88$ & 68,69 & $7.466 .049,02$ & 31,31 \\
\hline
\end{tabular}

Fonte: sepog. ro.gov.br

Como resultado do zoneamento, o estado de Rondônia é constituído por 33 Unidades de conservação (UC), que totalizam 1.802.306,44 ha de áreas protegidas, e representa 7,59\% do território.

Conforme o PDES-RO (2015, p. 44),

Dessas, 22 são de uso sustentável e 11 de proteção integral. Destaca-se o número de Reservas Extrativistas, que representam $81 \%$ das unidades de uso sustentável, todas estaduais. Já na categoria de proteção integral, predominam as unidades federais. No total, a maioria das unidades são federais, representando $63 \%$.

Essas Unidades de Conservação representam um ambiente de preservação da natureza, além de possibilitar planejamento objetivando a integração do homem-natureza. 
Figura 6 - Mapa das Áreas Protegidas do Estado de Rondônia

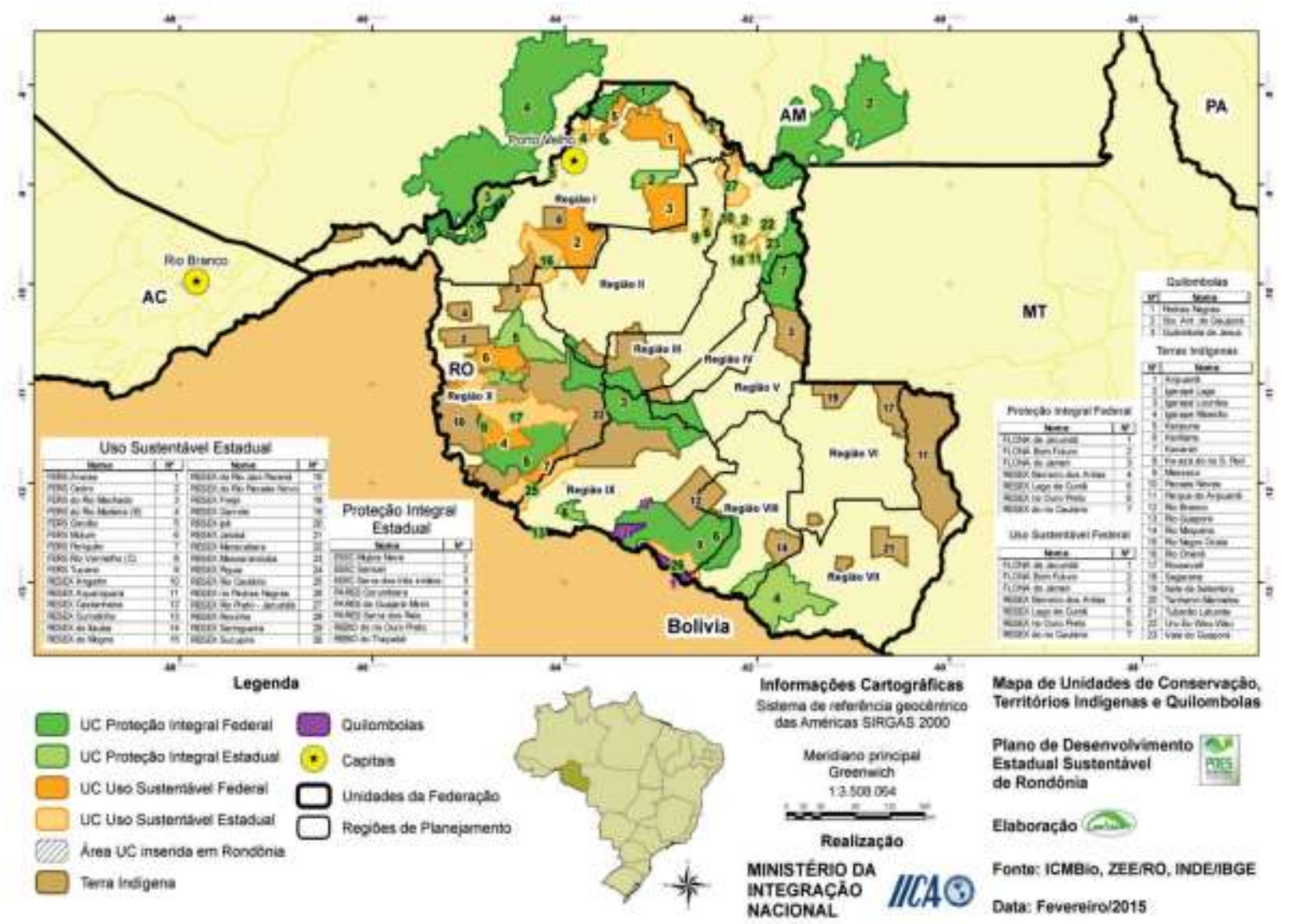

Fonte: PDES-RO, 2015.

Além das Unidades de Conservação (UC), conforme o Figura 6, destaca-se a existência de 23 terras indígenas protegidas. Nesse sentido, o PDES (2015, p.46) aponta:

Rondônia possui 23 Terras Indígenas, desde áreas pequenas, como a Terra Indígena Aripuanã, a menor delas, com área de 196 hectares, até áreas extensas, ocupando 38,22\% da área do Estado, como na Terra Indígena UruEu-Wau-Wau, que se distribui por 13 municípios.

Alguns desses territórios se sobrepõem a unidades de conservação, como é o caso da Terra Indígena Uru-Eu-Wau-Wau, do Parque Nacional de Pacaás Novos, da Terra Indígena Massaco e da Reserva Biológica Guaporé.

As áreas indígenas podem ser observadas conforme Figura 7, porém mesmo estando demarcadas não significa que estejam protegidas, visto que existem ameaças constantes de invasão tanto por parte de madeireiros quanto por pessoas estimuladas por políticos regionais. 
Figura 7 - Terras Indígenas e Unidades de Conservação de Proteção Integral em Rondônia

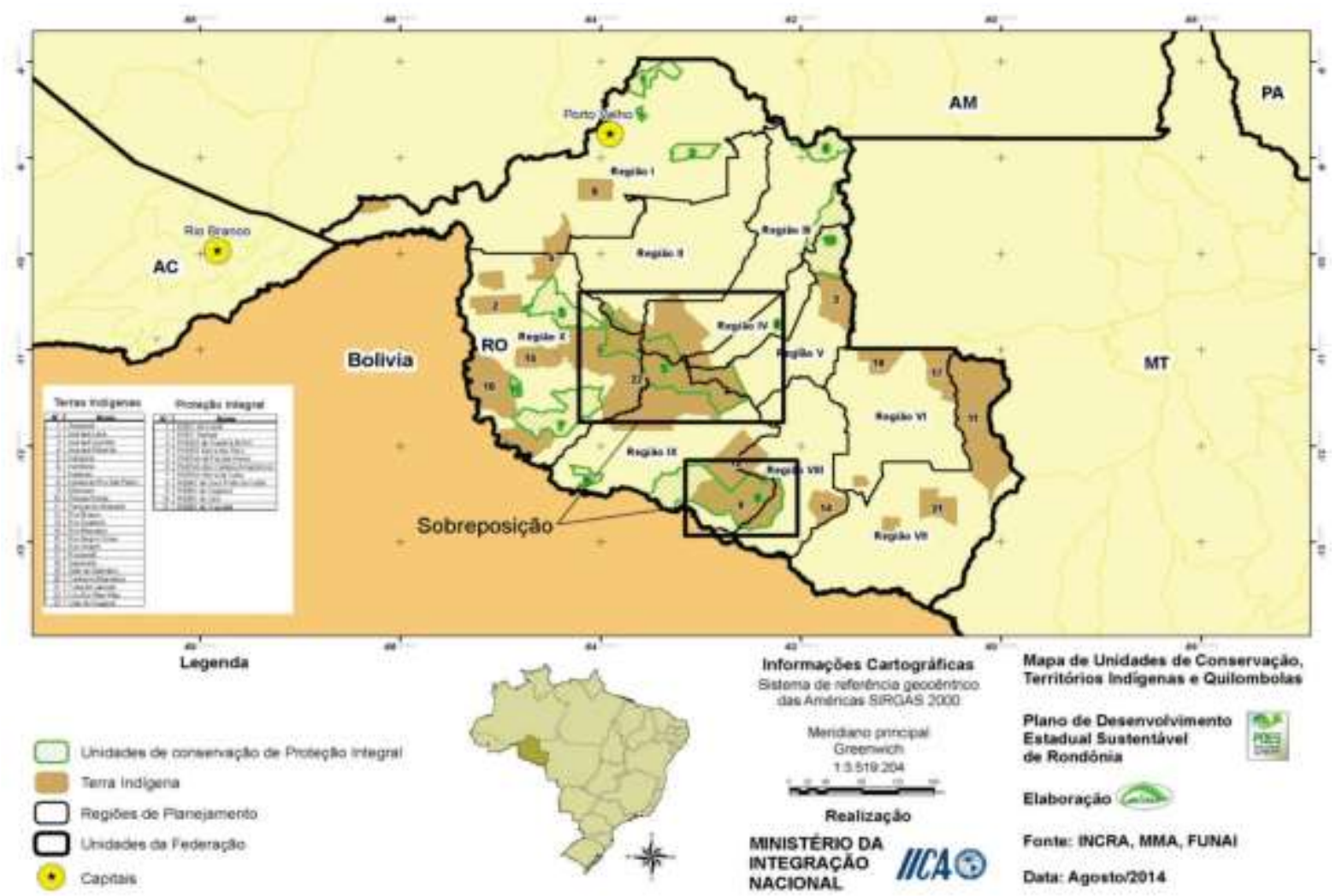

Fonte: PDES, 2015.

\subsubsection{Atualização da $2^{\mathrm{a}}$ aproximação do ZSEE-RO}

Após 20 anos da implementação da legislação da $2^{\text {a }}$ aproximação do ZSEE-RO, o governo promoveu, em 2020, a sua revisão. Conforme o documento "Atualização da $2^{\mathrm{a}}$ (Segunda) Aproximação do Zoneamento Socioeconômico-Ecológico do Estado de Rondônia - Resumo Executivo" Rondônia (2018, p.36), ao se referir da necessidade de atualização da segunda aproximação,

[...] a proposta de alteração do ZSEE-RO inclui a definição espacial de três categorias zonais e nove categorias de subzonas, com suas respectivas diretrizes de uso e ocupação dos solos, indicando as atividades econômicas mais viáveis do ponto de vista socioeconômico e ambiental [...].

O que se observa é a necessidade do governo em legalizar áreas anteriormente destinadas à proteção ambiental e que foram ocupadas. Conforme o citado documento Rondônia (2018, p.55), há a necessidade resguardar as condições socioambientais:

A proposta de execução do ZSEE-RO vem ao encontro da necessidade de resguardar as condições ambientais do Estado, ao mesmo tempo, melhorando as condições de vida da população e a manutenção de atividades econômicas de forma planejada, permitindo assim, a conservação de importantes áreas que ainda mantém a diversidade biológica e garantindo a 
manutenção de serviços ecológicos essenciais para o desenvolvimento de um território realmente sustentável.

Em contraposição, verifica-se a fala do coordenador da Coordenadoria de Geociência da SEDAM, Antônio de Melo Lisboa, em matéria publicada em 12 de abril de 2019, no site 4 oficial da SEDAM:

$\mathrm{Na}$ criação do Estado, o mapa mostrava Rondônia com apenas dois municípios: Porto Velho e Guajará-Mirim. Em 1988, quando foi apresentado o primeiro zoneamento (primeira aproximação), o mapa já apresentava 24 municípios e em 2002, quando foi apresentado o mapa da segunda aproximação, 52 municípios formavam Rondônia, no entanto, chamava a atenção, a quantidade devastada de vegetação: ou seja, quase 30\% do Estado desmatado, o que requereu medidas de proteção de áreas ainda preservadas. Outro exemplo é especificação de aldeias indígenas e áreas de quilombo.

Nessa perspectiva, é perceptível que a atualização da segunda aproximação, como trata o governo, vem para legalizar as áreas ocupadas recentemente. Da mesma forma, Silva (2018, p.223) ao analisar a dinâmica de ocupação territorial em Rondônia, destaca:

\begin{abstract}
As dinâmicas territoriais locais apontam para a pressão política, econômica e social em áreas protegidas, como as Terras Indígenas e Unidades de Conservação, assim, como, a ocupação de terras ainda sem função econômica, normalmente área públicas ocupadas e disputadas por diversos grupos sociais e econômicos (camponeses, madeireiros, pecuaristas, grileiros de terras de terras dentre outros). [...] No plano de gestão do território, a política estadual de ordenamento territorial (Zoneamento Socioeconômico e Ecológico) sofre permanentes modificações, sendo confrontada pelos diversos agentes territoriais desejosos da construção de novos territórios.
\end{abstract}

Nessa direção, observa-se que pelo Decreto $n^{\circ}$ 23.453, de 19 de dezembro de 2018, que dispõe sobre o artigo $2^{\circ}$ do Decreto $\mathrm{n}^{\circ} 21.906$, de 2 de maio de 2017, que criou a Comissão Estadual de Zoneamento do Estado de Rondônia, o governo participa com 11 (onze) representantes e a sociedade civil com 5 (cinco). Entre essas representações da sociedade civil, 2 (duas) são de empresários, a saber: a Federação das Indústrias de Rondônia (FIERO) e a Federação da Agricultura e Pecuária do Estado de Rondônia (FAPERON). Chama atenção a desproporcionalidade na correlação de forças na referida comissão, visto que não possibilita a manifestação qualificada da sociedade civil e consequentemente não

\footnotetext{
4 Zoneamento socioeconômico e ecológico de Rondônia será apresentado em reunião com integrantes da Comissão Estadual. Disponível em: <http://www.sedam.ro.gov.br/zoneamento-socioeconomico-eecologico-de-rondonia-sera-apresentado-em-reuniao-com-integrantes-da-comissao-estadual/ $>$. Acessado em: 15/05/2019.
} 
possibilita a mediação, a exemplo do que aconteceu na $2^{a}$ Aproximação. É perceptível que governo não vem valorizando a atuação da sociedade civil nas tomadas de decisão.

\subsubsection{Hidrelétricas do rio Madeira}

Para poder compreender a construção das chamadas usinas do Madeira, é necessário considerar a geopolítica internacional para a região. Nesse contexto, as hidrelétricas na Amazônia podem ser vistas como um suporte para o uso energético no processo da mineração e atendimento do mercado brasileiro como um todo. Padula (2014), ao analisar a política de integração da América do Sul, destaca que a criação da Integração da Infraestrutura Regional Sul-Americana (IIRSA) se deu no ano de 2000, cujo objetivo era criar uma infraestrutura para a integração região e abrir caminhos para outros mercados fora da região. Nessa perspectiva, o autor destaca vários Eixos de Integração e Desenvolvimento (EID). No que se refere o eixo que envolve a região de Rondônia, diz:

O Eixo Peru-Brasil-Bolívia abrange os principais nós de articulação localizados próximos à zona de tríplice fronteira, incluindo as articulações hidroviárias e o potencial hidrelétrico do complexo Madeira-Mamoré. É por meio deste eixo que um conjunto de obras viárias - com destaque para a rodovia Interoceânica do Pacífico, também chamada Iirsa Sur, de quase 3 mil km - cruza o território peruano, conectando o Sul do país com estados amazônicos e do Centro-Oeste do Brasil, complementando o Eixo do Amazonas e articulando estes espaços ao Pacífico. (PADULA, 2014, p. 318)

Como se observa, a IIRSA tem como orientação o projeto neoliberal, cuja visão política está voltada ao capital exportador. Assim, busca definir políticas que deem suporte à criação de infraestrutura como transporte multimodal, ou seja, ferrovias, rodovias e hidrovias, bem como de construção de hidrelétricas na região, embora as UHE do madeira (Santo Antônio e Jirau) não sirvam como instrumento de cabotagem, visto que elas não tem eclusas, contudo, pode ser entendido como fazendo parte do contexto, visto que o fornecimento de energia vem também para atender o mercado exportador. 
Figura 8 - Eixo Integrado de Expansão na América do Sul

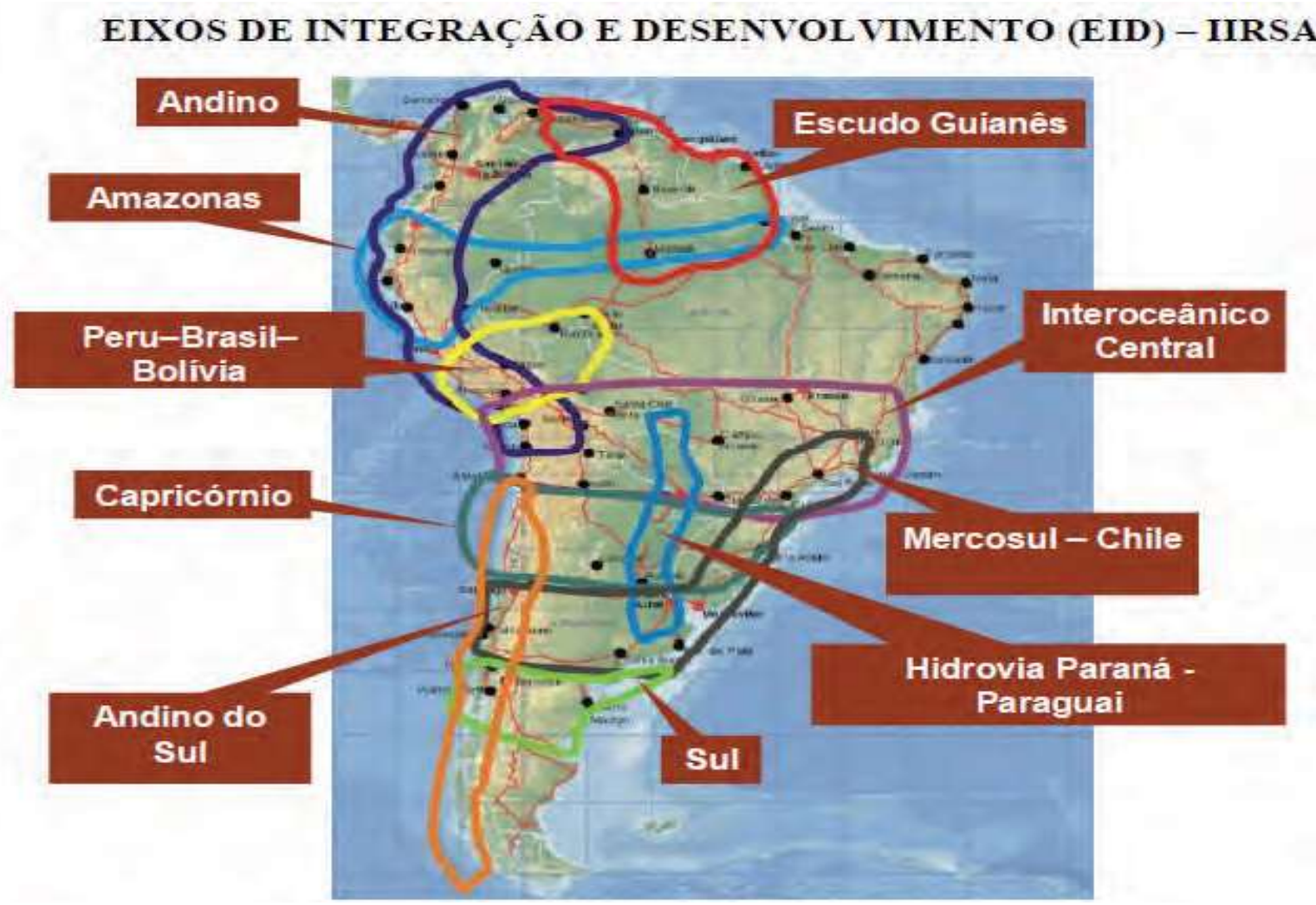

Fonte: IIRSA.

Como se observa no mapa 8, o traçado ou Eixo de Integração e Desenvolvimento (EID) tem como objetivo principal a expansão do comércio na região sul-americana. Stolerman et al (2014, p. 374), ao abordarem sobre as hidrelétricas do Madeira, expõem

[...] que o empreendimento faz parte do conjunto de estratégias da Integração da Infraestrutura Regional Sul-Americana - IIRSA, cujo objetivo consiste na modernização da infraestrutura de transporte, energia e telecomunicações, mediante ações conjuntas, de modo a estimular a integração política, econômica, sociocultural da América do Sul.

Para Fearnside (2015), sobre as hidrelétricas na região norte, existe um planejamento do governo brasileiro denominado 'Plano 2010' em que prevê a construção de 79 barragens na Amazônia e destaca:

As represas inundariam 10 milhões de hectares, ou aproximadamente $2 \%$ da região da Amazônia Legal e aproximadamente 3\% da porção brasileira da floresta amazônica. Inundar esta área provocaria perturbação de florestas em áreas maiores que os reservatórios em si. Os habitats aquáticos seriam alterados drasticamente. $\mathrm{O}$ impacto sobre povos indígenas também seria grande, sendo que uma das partes da Amazônia com maior concentração desses povos se encontra na faixa da maioria dos locais que são favoráveis para desenvolvimento hidrelétrico: ao longo dos trechos medianos e superiores dos afluentes que começam no planalto central 
brasileiro e seguem ao norte para encontrar com o rio Amazonas: o Xingu, Tocantins, Araguaia, Tapajós e outros. (FEARNSIDE, 2015, p.13).

Nesse contexto, foram construídas as duas usinas hidrelétricas de grande porte no rio Madeira, no município de Porto Velho, as usinas de Santo Antônio e de Jirau, inauguradas em 2016; cada uma possui 50 turbinas do tipo bulbo com potência de geração de energia elétrica com cerca de 71,6 megawatts (MW) cada, totalizando 3.568,3 MW de potência instalada, e 2.424 MW de potência assegurada. Essas usinas estão interligadas através de "linhão" ao sistema elétrico do centro-oeste e sudeste, somando-se ainda com a Usina de Samuel (UHS), localizado no município de Candeias do Jamari/RO, inaugurada na década de 1980.

Segundo Amaral, Morete e Marta (2018, p.257) “[...] as três grandes usinas de Rondônia (Jirau, Samuel e Santo Antônio) têm a capacidade de geração outorgada de 6,7 GW" e destacam a existência de 17 Pequenas Centrais Hidrelétricas (PCHs) e 26 Usinas Termelétricas (UTEs), gerando mais 306.001 MWh. Conforme Fearnside (2015, p.140) "O impacto do reservatório é, portanto, toda a área inundada $\left(271 \mathrm{~km}^{2}\right.$ em Santo Antônio +258 $\mathrm{km}^{2}$ em Jirau $=529 \mathrm{~km}^{2}$ ), cerca do dobro dos números muitas vezes apontados ao descrever o projeto $\left(138 \mathrm{~km}^{2}\right.$ em Santo Antônio $+110 \mathrm{~km}^{2}$ em Jirau $\left.=241 \mathrm{~km}^{2}\right)$ ". Esses impactos devem ser levados em consideração: a desterritorialização das comunidades tanto tradicionais (ribeirinhos e extrativistas) quanto das comunidades originárias (indígenas).

Stolerman et al (2014, p. 374) analisam sobre os impactos dessas hidrelétricas:

No caso das UHEs na Amazônia, notadamente em Rondônia, os impactos decorrentes da implantação dos empreendimentos hidrelétricos atingem indistintamente todos seus habitantes, visto que o Estado se constitui como provedor da geração elétrica, enquanto as receitas com a arrecadação dos impostos são destinadas em sua maioria para outras Unidades da Federação (inclusive mais ricas e com melhores infraestruturas).

Merece serem ressaltadas que as populações indígenas e tradicionais (ribeirinhas, pescadores) são aquelas que recebem os maiores impactos sociais, culturais e econômicas, sendo que muitas delas são compelidas a encontrar outras territorialidades distintas das suas, diluindo seus referenciais de vida.

Assim, verifica-se que várias comunidades localizadas, tanto a jusante quanto a montante do rio Madeira onde os empreendimentos das hidrelétricas Santo Antônio e Jirau foram instalados, foram afetadas e expulsas de suas terras onde moravam e trabalhavam há anos. Como exemplos, observa-se as Vilas de Mutum Paraná e Jirau, afetadas pela UHE Jirau e a Vila da Cachoeira de Santo Antônio, afetada pela UHE de Santo Antônio, além de 
inúmeros moradores ribeirinhos que viviam as margens do rio praticando a pesca artesanal para viver, tiveram que buscar outros habitats para morar, sendo desterritorializados, abandonando as suas tradições e seus lugares sagrados, como cemitérios. Além dessas comunidades, também foram afetados territórios indígenas que tiveram suas comunidades inundadas e o desaparecimento de seus patrimônios.

A Comissão Permanente Defensores de Direitos Humanos e Enfrentamento à Criminalização dos Movimentos Sociais, do Conselho Nacional de Direitos Humanos (CNDH), observou, em 2016, "in loco" sobre os impactos das 02 (duas) hidrelétricas - Santo Antônio e Jirau, no rio Madeira, nas comunidades afetadas pelos empreendimentos, destacando as comunidades dos distritos de Jaci-Paraná e Abunã.

Jaci-Paraná era um distrito pequeno, cortado pelos trilhos da Estrada de Ferro Madeira Mamoré. Jaci-Paraná foi afetado pelas duas usinas hidrelétricas construídas no rio Madeira. Com a implantação da UHE Jirau, sofreu o impacto socioambiental gerado pelo inchaço populacional - vinte mil pessoas migraram para a região para trabalhar na usina. Além disso, Jaci-Paraná foi atingido pelo lago da hidrelétrica de Santo Antônio, à jusante de Jirau. Desde 2013, as famílias de Jaci-Paraná e o Movimento dos Atingidos por Barragens (MAB) vêm denunciando intensamente os impactos provocados pela formação do reservatório da hidrelétrica de Santo Antônio no distrito, que estão se intensificando ao longo dos anos de diversas maneiras, não somente com a expansão da área do lago, mas também pelo encharcamento do solo, pela elevação do lençol freático e a consequente contaminação das fontes de água para consumo humano, entre outros problemas, como a proliferação de macrófitas aquáticas no reservatório desencadeando a reprodução desenfreada de mosquitos do gênero Mansonia sp. (CNDH, 2016, p.12).

Da mesma forma o relatório do $\mathrm{CNDH}$ (2016, p.14) analisa o impacto na vila de Mutum Paraná:

Mutum Paraná era uma comunidade ribeirinha situada entre o rio Mutum e o rio Madeira. Outro antigo ponto de parada do trem da Estrada de Ferro Madeira Mamoré, escoava a produção de látex dos seringais da região. Toda a comunidade de Mutum Paraná foi removida para a formação do lago de Jirau. Algumas famílias foram remanejadas para as casas construídas em Nova Mutum Paraná. Muitas não foram indenizadas ou receberam indenizações parciais.

Essas comunidades viviam há anos do extrativismo vegetal, garimpagem manual e da pesca artesanal, e ao serem afetadas pelas UHE são forçadas a se transferir para outras localidades, e além de não terem suas terras indenizadas por um preço justo, perdem a sua identidade cultural e consequentemente o seu trabalho. 


\subsubsection{Divisão agrícola do Estado}

Visando estimular o processo econômico regional, o governo do Estado aprovou a Lei complementar $n^{\circ}$ 414/2007 criando 10 (dez) regiões. Nessa divisão regional, observa-se que a estratégica de planejamento foi verificar a potencialidade agrícola e estimular o desenvolvimento local, tendo como orientação o Zoneamento Sócio-Econômico-Ecológico (ZSEE-RO).

\section{Figura 9 - Divisão agrícola de Rondônia}

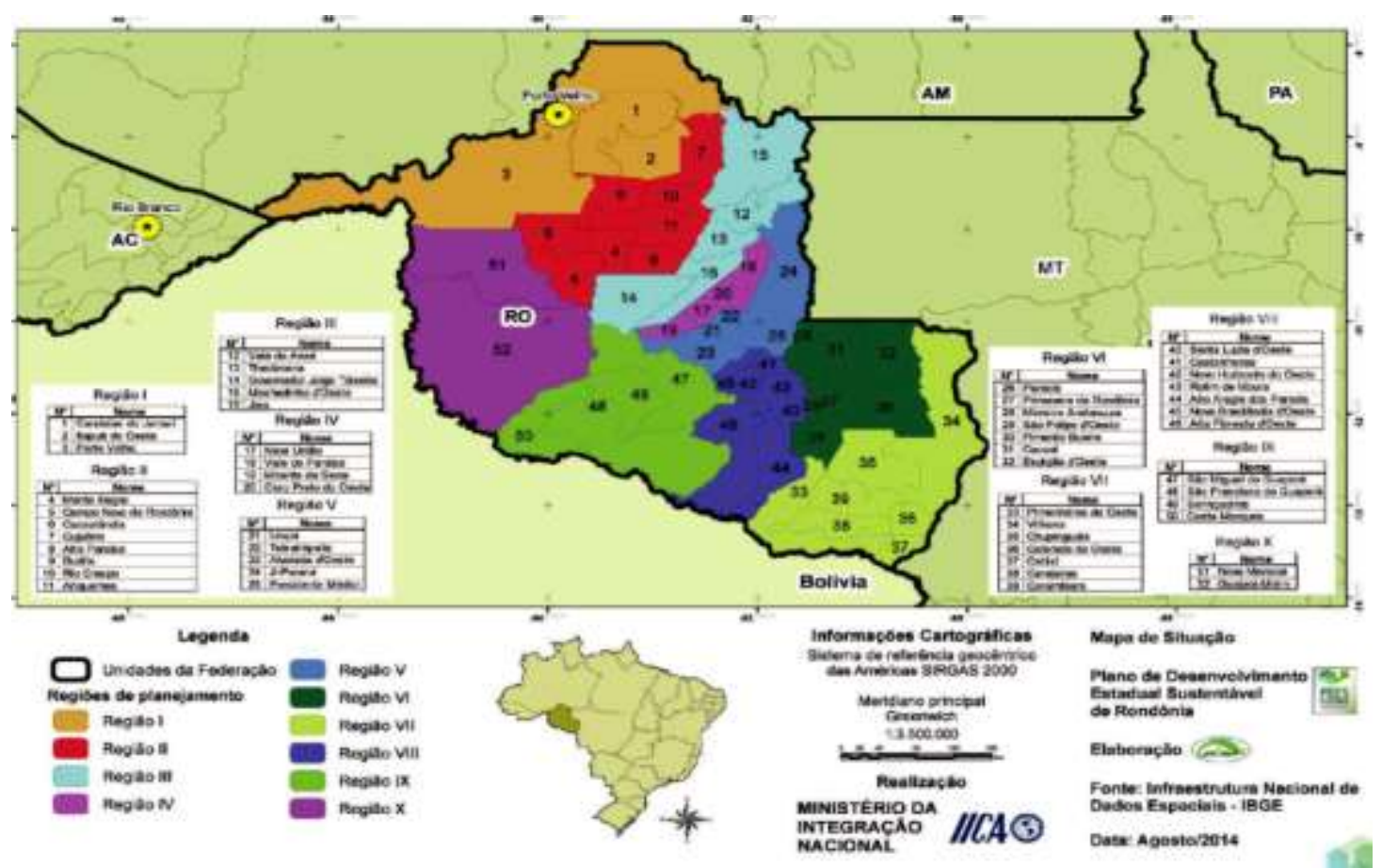

Fonte: PDES-RO. 2015

Quadro 6 - Regiões de Planejamento e Gestão para o Estado de Rondônia

\begin{tabular}{|l|l|}
\hline \multicolumn{1}{|c|}{ REGIAO } & \multicolumn{1}{c|}{ CIDADES } \\
\hline Região I - Porto Velho & Candeias do Jamari e Itapuã do Oeste. \\
\hline Região II - Ariquemes & $\begin{array}{l}\text { Alto Paraíso, Buritis, Cacaulândia, Campo Novo de Rondônia, Cujubim, Monte } \\
\text { Negro e Rio Crespo. }\end{array}$ \\
\hline Região III - Jaru & Governador Jorge Teixeira, Theobroma, Vale do Anari e Machadinho do Oeste. \\
\hline Região IV - Ouro Preto do Oeste & Mirante da Serra, Nova União e Vale do Paraíso. \\
\hline Região V - Ji-Paraná & Alvorada D’Oeste, Texeirópolis, Presidente Médici e Urupá. \\
\hline Região VI - Cacoal & $\begin{array}{l}\text { Ministro Andreazza, Espigão D’Oeste, Pimenta Bueno, Primavera de Rondônia, } \\
\text { São Felipe e Parecis. }\end{array}$ \\
\hline Região VII - Vilhena & Chupinguaia, Colorado D’Oeste, Cerejeiras, Cabixi, Pimenteiras e Corumbiara. \\
\hline Região VIII - Rolim de Moura & $\begin{array}{l}\text { Novo Horizonte, Santa Luzia D’Oeste, Alto Alegre dos Parecis, Nova } \\
\text { Brasilândia, Castanheiras e Alta Floresta do Oeste. }\end{array}$ \\
\hline Região IX - São Francisco do Guaporé & Costa Marques, São Miguel do Guaporé e Seringueiras. \\
\hline Região X- Guajará Mirim & Nova Mamoré \\
\hline
\end{tabular}

Fonte: Lei complementar $n^{\circ}$ 414/2007

Como se observa no quadro 6, a divisão geográfica foi ordenada com base em estudos georeferenciados, o que possibilitou um planejamento socioeconômico por região, resultando 
na produção de alimentos e mais recentemente em agricultura de larga escala, como a soja e pecuária de corte.

Figura 10 - Propriedades rurais existentes no estado de Rondônia

PROPRIEDADES RURAIS NO ESTADO DE RONDONIA POR TAMANHO DE AREA E PORTE 2019

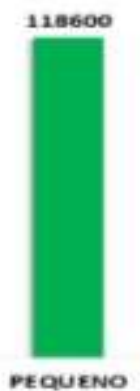

\begin{tabular}{cccc}
\hline PORTE & HECTARES & QUANTIDADE & PERCENTUAL \\
\hline PEQUENO & ATE 240 & 118.600 & $85 \%$ \\
MEDIO & DE 241 A 900 & 16.743 & $12 \%$ \\
GRANDE & ACIMA DE 900 & 4.186 & $3 \%$ \\
TOTAIS & 139.529 & 10096 \\
\hline
\end{tabular}

Fonte: SEAGRI, 2020.

Como se pode observar na Figura 10, a pequena e média agricultura somam 124.232 propriedades, com um percentual de 97\%, enquanto a grande propriedade conta com 4.186, correspondendo a 3\%. Ainda assim, conforme o próprio Plano de Desenvolvimento Estadual Sustentável de Rondônia (PDES, 2015, p.63), a pequena e média propriedade vem sofrendo com a concepção da monocultura proporcionada pelo agronegócio:

No entanto, o avanço da agricultura moderna em Rondônia, ao promover também a monocultura, a grande propriedade e o agronegócio (que também tem sido um dos grandes motores do crescimento econômico estadual) cria conflitos diversos com a agricultura familiar. Verifica-se, por exemplo, que os serviços de assistência técnica, cuja oferta governamental e privada não atende a todos, acaba por privilegiar setores mais organizados e mais poderosos, que também são capazes de influenciar e direcionar as políticas públicas e recursos de investimentos governamentais. Além disso, cria um ambiente de disputa pela terra, que tende à concentração, gerando monopólio da propriedade e do uso da terra, que se desdobra em elevação dos preços. A monocultura, como a soja, pode ainda trazer riscos de contaminação das culturas tradicionais, dado o uso intensivo de defensivos agrícolas.

Como se pode observar, Rondônia da atualidade (2020), devido à expansão do agronegócio da soja e da pecuária de corte, agregado ao uso das novas tecnologias do campo e à falta de políticas públicas de apoio aos pequenos proprietários rurais tem proporcionado conflitos agrários pela disputa da posse da terra. Pressionados pelo grande capital os agricultores, ou arrendam ou vendem os seus lotes, abrindo uma migração para o sul do estado do Amazonas e/ou para o estado do Acre. 


\section{DESENVOLVIMENTO REGIONAL E O ODR COMO MECANISMOS DE MEDIAÇÃO}

Neste capítulo será feita uma análise com o objetivo de verificar se a concepção de desenvolvimento sustentável, definida no Plano de Desenvolvimento Estadual Sustentável de Rondônia (PDES-RO), vem sendo adotada pelo governo, bem como se o Observatório de Desenvolvimento Regional (ODR) vem cumprindo os objetivos que justificaram sua criação pelo PDES-RO.

O PDES-RO tem como base as diretrizes estabelecidas pela Política Nacional de Desenvolvimento Regional (PNDR ${ }^{5}$ ) e pela I Conferência Nacional de Desenvolvimento Regional (CNDR). Conforme o PEDS-RO (2015, p.18), os eixos a serem seguidos pela governança do estado com vistas à implantação de políticas públicas são: “i) adoção da abordagem territorial, ii) desenvolvimento sustentável, iii) desenvolvimento social, iv) enfretamento da problemática da infraestrutura e logística e v) fomento do desenvolvimento regional/local com inclusão produtiva". Por outro lado, a base para se implantar as políticas públicas pelo estado, na região, toma como referencial a concepção de desenvolvimento sustentável, destacando 4 (quatro) diretrizes, levando em conta o PNDR:

[...] 1) Territorialização e Gestão Ambiental; 2) Bem-Estar Social; 3) Competitividade Sustentável; e 4) Modernização da Gestão Pública. O planejamento contempla 28 programas e 157 projetos, estruturado em um Plano de Metas para o Estado de Rondônia, em um horizonte de 15 anos, tendo-se como parâmetros de execução de curto prazo, 5 anos; de médio prazo, 10 anos; e de longo prazo, 15 anos.

Para a sua execução está prevista a implementação de um modelo de gestão, de um fluxo de informações a serem disponibilizadas no Observatório de Desenvolvimento Regional (ODR), de estratégias de implementação, da correlação entre seus programas e projetos com o PPA Federal e Estadual, de resultados esperados com o uso de indicadores, além das fontes de financiamento e incentivos fiscais disponíveis. (PDES-RO, 2015, p.18).

Já o Observatório de Desenvolvimento Regional (ODR), além de ser um dispositivo de informações, como estabelecido no PDES-RO, desempenha função de monitoramento das ações políticas do governo, bem como serve como um instrumento de mediação. Nesse sentido, o MI/SDR $\%$ ODR (2015, apud PDES, 2015, p. 214), orienta que os indicadores e as

\footnotetext{
${ }^{5}$ Art. $1^{\circ}$ do Decreto no 9.810, de 30/05/2019 diz: "Fica instituída a Política Nacional de Desenvolvimento Regional - PNDR, cuja finalidade é reduzir as desigualdades econômicas e sociais, intra e inter-regionais, por meio da criação de oportunidades de desenvolvimento que resultem em crescimento econômico, geração de renda e melhoria da qualidade de vida da população".

${ }^{6}$ SDR - Secretaria de Desenvolvimento Regional do Ministério da Integração Nacional.
} 
metas da gestão deverão estar disponibilizados no ODR que tem como objetivo “[...] aprimorar a avaliação, o monitoramento e, consequentemente, a gestão da Política Nacional do Desenvolvimento Regional (PNDR)", e ainda:

Trata-se de um instrumento de controle social e confere transparência à gestão dos recursos públicos, atendendo a crescente demanda da sociedade brasileira. E vai além, pois se constitui em uma ferramenta de pesquisa das ações do governo federal disponível para a sociedade que, por meio de suas análises, deve interagir e colaborar com o poder público para aperfeiçoar os seus gastos e tornar mais eficientes suas ações. [...] O sistema consta de três partes: 1) Acompanhamento do alcance das metas programadas. Indicadores de desempenho (eficiência); 2) Acompanhamento dos resultados esperados. Indicadores de efeitos (eficácia); e 3) Indicadores de Avaliação de impactos (efetividade). (MI/SDR/ODR, 2015, apud PDES-RO, 2015, p. 214).

Dessa forma, o ODR se constitui em um instrumento de avaliação das políticas do governo, e "possibilita" a interação da sociedade civil com o poder público visando discussão, elaboração e o aprimoramento de políticas públicas a serem implantadas no estado de Rondônia.

A abordagem sobre desenvolvimento sustentável deve levar em conta a responsabilidade ética, mudanças de posturas frente o ambiente como um todo. Nessa perspectiva, Siqueira S.J. (2009, p.91) aponta:

A ética ambiental não é apenas um saber acadêmico preocupado com a formação de uma consciência crítica voltada para a busca de sustentabilidade socioambiental, mas é também uma atividade prática que mexe com as mudanças de posturas das pessoas, transformando o modo de ser e agir da relação de ser humano com a natureza.

Como se pode observar no texto do autor, a responsabilidade com o planeta é um dever da sociedade como um todo. Por outro lado, deve-se levar em conta o crescimento da população mundial, e dessa forma deve-se pensar na superação das desigualdades sociais a partir do local/regional. Assim, é necessária mudança de habitus da população, ou seja, adoção de ações que visem estancar a busca exagerada pelo consumismo, pensando em uma sociedade que garanta espaços de convivência no planeta para as futuras gerações. Nessa perspectiva, a autora destaca:

Não devemos colocar o pensar para a dimensão do global e o agir para o local, como dizia a tradicional frase: 'pensar globalmente e agir localmente'. Hoje, esta afirmação está superada, pois o que acontece no global tem repercussão no local e toda ação local reflete-se no global. Daí a importância de construção de um localismo globalizado (SIQUEIRA S.J., 2009, p.96). 
Pensar o global a partir do local se constitui em uma preocupação social e ética na sociedade atual globalizada e essa preocupação deve levar em conta as mudanças climáticas que vem ocorrendo no planeta, decorrentes das ações antropizadas.

\section{Figura 11 - Crescimento por demanda por alimento no planeta}

\section{CRESCIMENTO DA DEMANDA POR ALIMENTOS NO MUNDO} (EM BILHOES DE TONELADAS POR ANO)

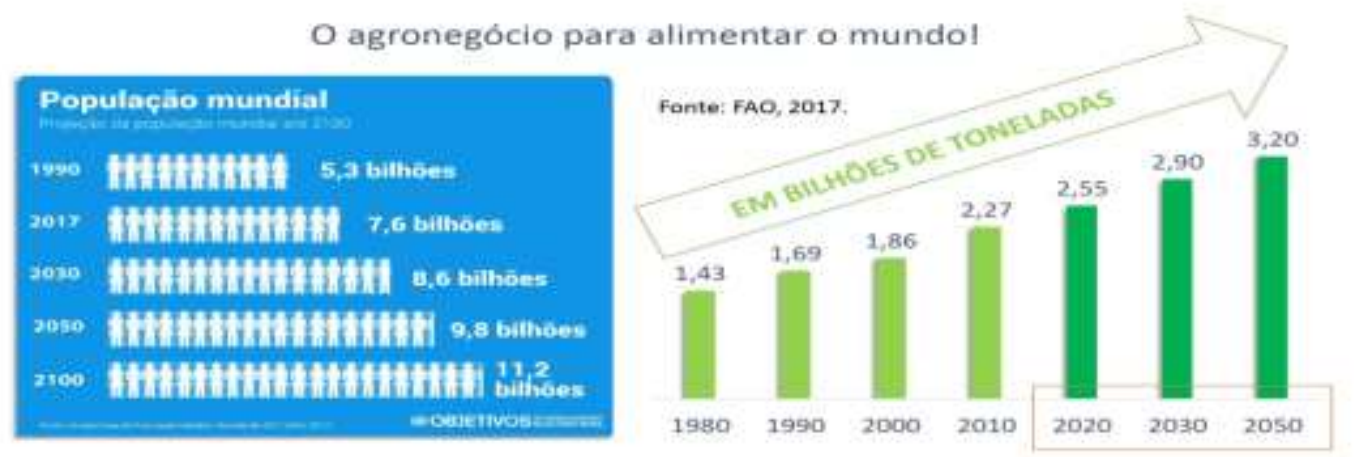

Fonte: SEAGRI, 2020.

Como se pode observar na Figura 11, existe uma estimativa crescente da população mundial, o que demanda por si só a necessidade de aumentar a produção de alimentos, devendo haver o uso racional do ambiente; entretanto o capital se arma com justificativas de que o fornecimento de alimentos pode crescer com o uso de insumos químicos, sem considerar os impactos energéticos (a produção dos fertilizantes consomem muito combustível), ambientais e sociais associados, que podem produzir alteração antrópica no sistema e levar ao colapso; não se pode alterar a entropia dos sistemas (crescentes impactos) sem produzir colapso no sistema.

Ademais, é necessário destacar que as políticas neoliberais, adotadas por diversos governos, têm assumido posicionamento indutivo de que o Estado ou o serviço público são incompetentes para gerir a economia, e dessa forma não é capaz de pensar e dirigir projetos que promovam o desenvolvimento social. Nessa lógica, se observa a diminuição do Estado e as ações de gestores sendo transferidas para as iniciativas privadas. Assim, verifica-se que os interesses privados fortalecem o capital econômico privado.

Mazzucato (2014) ao analisar esse comportamento, levanta questões referentes ao papel do Estado como gerenciador, tanto do setor público, quanto do setor privado e seus limites; destaca a importância do Estado como um ente fundamental na condução da economia e das ações sociais; busca desfazer o mito de que o Estado seja incompetente e que a iniciativa privada seja a única capaz de proporcionar resultados eficazes e eficientes para 
suprir as necessidades da sociedade, e dessa forma proporcionar a melhoria da qualidade de vida da população. Nesse sentido, a autora sugere uma avaliação programática da economia:

O que precisa discutir para reequilibrar a economia não é apenas o tamanho e o equilíbrio das atividades do setor financeiro. Não basta que os países incentivem a inovação ou pleiteiem o renascimento industrial. É preciso haver uma dinâmica funcional risco-recompensa que substitua a disfuncional 'risco socializado' e 'recompensa privatizada' que caracteriza a atual crise econômica, evidenciada na indústria moderna e no setor financeiro. $\mathrm{O}$ equilíbrio correto entre risco e recompensa pode fortalecer - em vez de enfraquecer - a inovação futura e refletir sua natureza coletiva através de uma difusão mais ampla de seus benefícios (sic) (MAZZUCATO, 2014, p.145).

O Estado, nesse contexto, deve ser visto como um ente indutor, capaz de executar projetos, bem como fomentar políticas que visem o desenvolvimento da sociedade, levando em conta as demandas existentes na sociedade e ainda incentivar iniciativas oriundas da sociedade civil, na busca de soluções, visando resolver problemas básicos da população a partir da realidade local/regional.

Sobre a forma de governança, Rua (1997, p.134) analisa a necessidade de se trabalhar concepções políticas e acadêmicas que possam responder desafios impostos pela própria sociedade, e diz:

Dentre os muitos e complexos desafios da reforma do Estado, um vem se destacando pela sua recente inclusão no debate político e acadêmico: a capacidade do sistema político de responder satisfatoriamente às demandas da sociedade e de enfrentar os desafios da eficiência e eficácia da ação pública em contextos de complexidade e incerteza crescente.

Observa-se que a gestão pública no exercício da governança deve levar em conta os recursos econômicos disponíveis para realizar investimentos em ações que priorizem as necessidades sociais. Ao mesmo tempo, é fundamental a adoção de procedimentos que demonstrem a capacidade gerencial do Estado como ente fundamental na promoção de políticas pública para a sociedade.

Outro contexto que deve ser considerado refere-se às informações adquiridas pelos gestores e o seu compartilhamento com a sociedade. Nesse sentido, Barreto (1998, p.14) diz que “[...] o objetivo da informação e de suas unidades gestoras, é promover o desenvolvimento do indivíduo, de seu grupo e da sociedade", e acrescenta:

As duas funções básicas de uma unidade de informação, responsáveis pela realização do objetivo final são: a função de produção da informação e a função de transferência da informação.

A primeira função é definida como produção de informação, que se operacionaliza com práticas bem definidas, apoiadas em um processo de 
transformação, que se orienta por uma racionalidade técnica, que lhe é específico; estas práticas são representadas por atividades relacionadas com a reunião, a seleção, o processamento e o armazenamento da informação, por exemplo. A produção de informação se acumula continuamente para formar os estoques de informação, que são quantidades estáticas de informação armazenadas em acervos, em geral, de bibliotecas, de arquivos, de museus, de bases de dados, de redes ou de sistemas de informação. Os estoques estáticos de informação são indispensáveis ao processo de geração de conhecimento. Mas por si só não efetivam este processo.

Constata-se no texto do autor que a informação é um elemento essencial não pelo seu objeto em si, mas pelo que ela pode proporcionar no sentido do conhecimento da realidade social, econômica e política, e dessa forma possa resultar nas buscas de soluções objetivando a melhoria da qualidade de vida em sociedade. Assim, os estoques de informações devem servir como base de dados que proporcionem a geração de conhecimento e que possam ser colocados à disposição de toda sociedade.

Nessa mesma perspectiva, Barreto (1998, p.3) afirma que a "finalidade básica de um sistema de informação é também, produzir conhecimento e assim alterar para melhor a realidade, promovendo o desenvolvimento desta realidade, levando-a a um melhor estágio de bem estar de seus membros". Dessa forma, a mediação deve ser percebida como agente indutor de informação que possa servir como ferramenta de mudanças intrínsecas nos indivíduos e na sociedade civil.

Por outro lado, os governos que representam o capital financeiro e sabendo que a informação é um valor simbólico de poder, a não disponibilização de informação como instrumento de mediação representa o controle social, a reprodução da ideologia dominante, ou seja, a manutenção do sistema capitalista monopolista.

\subsection{O GOVERNO E O DESENVOLVIMENTO REGIONAL}

O PDES-RO define que a política a ser implantada em Rondônia no período de 2015 a 2030 tem como referencial a concepção do desenvolvimento regional sustentável. Ao se manifestar sobre o PDES-RO, Daniel Pereira ${ }^{7}$, ex-governador e superintendente do SEBRAERO, definiu a concepção de desenvolvimento sustentável para Rondônia:

O Plano de Desenvolvimento Sustentável (PDES-RO) foi coordenado pela Secretária de Estado de Planejamento, Orçamento e Gestão (SEPOG), como uma das ações do governador Confúcio Moura. Confúcio tem uma história

\footnotetext{
${ }^{7}$ Daniel Pereira, bacharel em direito pela Universidade Luterana do Brasil em Porto Velho (ULBRA); ViceGovernador pelo PSB (eleição 2014), composição com PMDB e governador em 2018/19 e atual Superintendente do Serviço (SEBRAE). Entrevista concedida em fevereiro de 2020 na cidade Porto Velho-RO.
} 
política bem peculiar em que mostra dois momentos na vida dele. $\mathrm{O}$ primeiro momento se alinhava com os seguimentos mais conservadores. No segundo momento, mudou totalmente, passou a ver o mundo com o olhar voltado para Desenvolvimento Sustentável, dessa forma que nasceu a necessidade de se construir um estado que tenha a orientação da concepção baseado no desenvolvimento com preservação ambiental.

Nessa perspectiva, entrevistou-se Pedro Antônio Afonso Pimentel ${ }^{8}$, Secretário de Estado de Planejamento, Orçamento e Gestão (SEPOG), no governo anterior e atual, que indagado sobre o desenvolvimento sustentável, considerando o PDES-RO, manifestou:

[...] O PDES-RO foi criado com o objetivo de Estabelecer o planejamento do desenvolvimento sustentável do Estado, com base no conhecimento de sua realidade e nas políticas públicas voltadas ao desenvolvimento socioeconômico, mediante a execução de um conjunto de diretrizes e programas estruturantes por áreas de resultados. Foi lançado em 2015, fruto de uma parceria do Gov. de Rondônia com o Ministério da Integração Nacional.

De grande relevância não só para o órgão, mas para todo o Estado de Rondônia, foi à decisão de transformação do Plano em uma Política de Estado de Desenvolvimento Sustentável por meio da Emenda Constitucional $n^{\circ} 125 / 2017$. Uma política com foco no desenvolvimento integrado sem perder a perspectiva regional, que demonstra as potencialidades e estratégias de Desenvolvimento com adoção do conceito de Estado aberto e em rede, que atua, com outras esferas da sociedade, sem perder a posição de protagonista na priorização das estratégias governamentais e que propõe também um Estado que opera em parceria, a partir de grandes investimentos e incorpora como pilar a gestão orientada para resultados, sem negligenciar o equilíbrio fiscal e a qualidade do gasto público, orientado a produção de mais e melhores resultados para a sociedade rondoniense.

Observa-se na fala do Secretário da SEPOG que as ações do PDES-RO foram transformadas em políticas de Estado visando ao atendimento das peculiaridades regionais. Por outro lado, destaca que se faz necessária a adoção de um sistema de governança aberta em rede que possa trabalhar em parceria com a iniciativa privada, focando no resultado com equilíbrio da questão fiscal e dos gastos públicos. E acrescenta:

O Estado de Rondônia adota a filosofia do desenvolvimento que combina eficiência econômica com justiça social e prudência ecológica. Nesse sentido, adotou-se o conceito do Relatório de Brundtland, 1987, que é adotado pelos organismos internacionais e por todos os países, de que o desenvolvimento para ser sustentável deverá atender as gerações presentes sem esgotar as possibilidades das gerações futuras terem suas necessidades também atendidas. O desenvolvimento sustentável também é entendido

\footnotetext{
${ }^{8}$ Pedro Antônio Afonso Pimentel, graduado em Ciências Contábeis pela Universidade Federal de Rondônia (UNIR) secretário Adjunto de Planejamento Orçamento e Gestão (SEPOG) (2012- 2018); secretário de Planejamento Orçamento e Gestão (de maio a dezembro de 2018), secretário chefe da Casa civil (2019) e atualmente é Secretário de Estado de Planejamento, Orçamento e Gestão (SEPOG). Entrevista realizada em fevereiro de 2020, na cidade de Porto Velho-RO.
} 
como processo em constante mudança quanto à dinâmica dos investimentos, inovações (que devem cumprir demandas atuais e futuras) e exploração dos recursos naturais. Assim, reconhecemos a importância de assumir a ideia de sustentabilidade nas suas múltiplas dimensões: social, cultural, ecológica, ambiental, econômica, territorial, política nacional e política internacional, em qualquer programa ou atividade de desenvolvimento constante no PDESRO 2015-2030.

Nesse sentido, destaca-se o que diz a Agenda 21 - Conferência das Nações Unidas sobre Meio Ambiente e Desenvolvimento:

A Agenda 21 está voltada para os problemas prementes de hoje e tem o objetivo, ainda, de preparar o mundo para os desafios do próximo século. Reflete um consenso mundial e um compromisso político no nível mais alto no que diz respeito a desenvolvimento e cooperação ambiental. $\mathrm{O}$ êxito de sua execução é responsabilidade, antes demais nada, dos Governos (AGENDA 21, 1997, p. 9).

Para Natan Oliveira da Costa ${ }^{9}$, Coordenador das Secretarias Executivas Regionais da SEPOG e membro do Conselho Estadual de Desenvolvimento Rural Sustentável (CEDRS), com relação ao crescimento do agronegócio no estado, diz:

O crescimento da área plantada de commodities é uma preocupação que acompanhamos visto que fazemos parte do Conselho Estadual de Desenvolvimento Rural Sustentável (CEDRS) que trabalha a proteção da agricultura familiar. No Conselho há um esforço para se estabelecer políticas públicas de proteção ao pequeno agricultor para que ele não arrende suas terras para os grandes produtores $(\mathrm{Sic})$.

Natan Costa acrescenta que no estado de Rondônia não se tem grandes latifúndios e que "depois de Santa Catarina representa o melhor recorte fundiário do Brasil". Contudo, evidencia a preocupação com incentivo do governo ao agronegócio e completa dizendo: “em que pese às políticas públicas voltadas para questão do desenvolvimento agropecuário, eu vejo o conselho bastante preocupado na questão de proteger o agricultor familiar". Com esse olhar, o interlocutor admite a existência de conflitos agrários, porém não destaca ações de políticas que venham ao encontro do pequeno e médio agricultor.

\footnotetext{
${ }^{9}$ Natan Oliveira da Costa - Coordenador das Secretarias Executivas Regionais da Secretária de Estado de Planejamento, Orçamento e Gestão (SEPOG). Entrevista concedida na cidade de Velho-RO em fevereiro de 2020.
} 
Figura 12 - Desempenho da agricultura e pecuária em $R O$

\begin{tabular}{|c|c|c|c|c|c|}
\hline \multicolumn{6}{|c|}{ PARTICIPACAAO DAS 5 MAIORES CULTURAS EM RONDÓNIA } \\
\hline PRODUTOS & 2016 & 2017 & 2018 & 2019 & 2020 \\
\hline Amendoim & $0,0 \%$ & $0,0 \%$ & $0,0 \%$ & $0,0 \%$ & $0,0 \%$ \\
\hline Arroz & $1,5 \%$ & $1,0 \%$ & $0,9 \%$ & $1,1 \%$ & $0,9 \%$ \\
\hline Banana & $2,0 \%$ & $1,6 \%$ & $2,3 \%$ & $1,5 \%$ & $1,4 \%$ \\
\hline Cacau & $0,6 \%$ & $0,3 \%$ & $0,3 \%$ & $0,4 \%$ & $0,4 \%$ \\
\hline Cafe & $7,6 \%$ & $10,2 \%$ & $7.6 \%$ & $6,6 \%$ & $6,3 \%$ \\
\hline Cana-de-açǘcar & $0,3 \%$ & $0,3 \%$ & $0,0 \%$ & $0,0 \%$ & $0,0 \%$ \\
\hline Feijăo & $0,7 \%$ & $0,4 \%$ & $0,3 \%$ & $0,5 \%$ & $0,0 \%$ \\
\hline Laranja & $0,1 \%$ & $0,1 \%$ & $0,0 \%$ & $0,0 \%$ & $0,0 \%$ \\
\hline Mandioca & $3,4 \%$ & $1,9 \%$ & $1,9 \%$ & $1,7 \%$ & $1,1 \%$ \\
\hline Milho & $4,6 \%$ & $4,1 \%$ & $3,7 \%$ & $5,1 \%$ & $6,6 \%$ \\
\hline Pimenta-do-reino & $0,0 \%$ & $0,0 \%$ & $0,0 \%$ & $0,0 \%$ & $0,0 \%$ \\
\hline Soja & $10,7^{2}$ & $8,5 \%$ & $10,7 \%$ & $11,5 \%$ & $12.8 \%$ \\
\hline Tomate & $0,1 \%$ & $0,1 \%$ & $0,0 \%$ & $0,0 \%$ & $0,0 \%$ \\
\hline Uva & $0,0 \%$ & $0,0 \%$ & $0,0 \%$ & $0,0 \%$ & $0,0 \%$ \\
\hline Bovinos & $49,9 \%$ & $53,3 \%$ & $56,3 \%$ & $56,8 \%$ & $57,1 \%$ \\
\hline Suinos & $0,1 \%$ & $0,0 \%$ & $0,0 \%$ & $0,0 \%$ & $0,0 \%$ \\
\hline Frango & $1.2 \%$ & $1,2 \%$ & $1,7 \%$ & $1,8 \%$ & $1,6 \%$ \\
\hline Leite & $9,6 \%$ & $6,5 \%$ & $6,3 \%$ & $6,0 \%$ & $5,1 \%$ \\
\hline Ovos & $0,4 \%$ & $0,3 \%$ & $0.2 \%$ & $0,3 \%$ & $0,3 \%$ \\
\hline TOTAL. & $100 \%$ & $100 \%$ & $100 \%$ & $100 \%$ & $100 \%$ \\
\hline
\end{tabular}

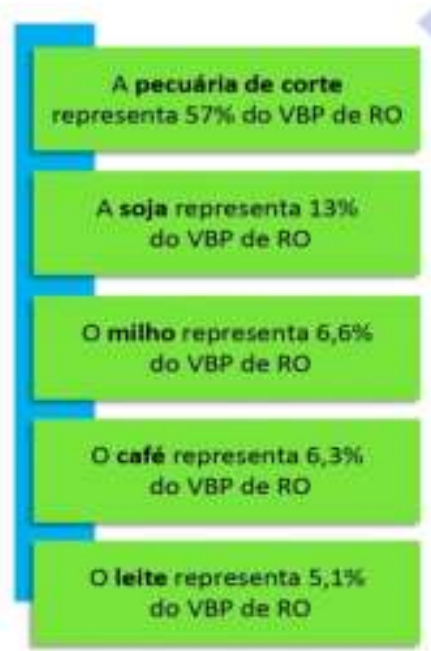

Fonte: SEAGRI, 2020.

Observa-se, pela figura 12, que há uma expansão do agronegócio em Rondônia, destacando-se a produção da carne bovina, que representa 57\% do Valor Bruto da Produção $\left(\mathrm{VBP}^{10}\right)$, seguido da soja em $13 \%$, o milho em $6,6 \%$, o café em $6,3 \%$ e o leite $5,1 \%$.

Figura 13 - Representação financeira do agronegócio em $R O$

\begin{tabular}{|c|c|c|c|c|c|}
\hline \multicolumn{6}{|c|}{ VALOR BRUTO DA PRODUÇÁO AGROPECUÁRIA } \\
\hline RONDONIA & Fonte IAGE, 2020 & & & & Valores em R\$* \\
\hline & $2016=$ & 2017 & 2018 & 2019 & 2020 \\
\hline Amendoim & 143.631 & 70.270 & 19.715 & 284.430 & 261,920 \\
\hline Arroz & 154.907 .655 & 112.458 .963 & $101.744,714$ & 125.438 .935 & 116.370 .725 \\
\hline Banana & 198.247 .908 & 184.023 .965 & 259.180 .384 & $176,591.062$ & 175.490 .469 \\
\hline Cacau & 57.965 .609 & $37,182.995$ & $36,801.654$ & 47.920 .078 & $54,018.333$ \\
\hline Cafe Total & 762.743 .558 & 1.194765 .929 & 840.808 .110 & $750,396,050$ & 806.757 .591 \\
\hline Cafe conilon & 762.743 .558 & 1.194 .765 .929 & 840.808 .110 & 750.396 .050 & 806.757 .591 \\
\hline Cana-de-açucar & 28.966 .890 & 32.624 .996 & 1.229 .121 & 4.867 .235 & 6.041 .719 \\
\hline Feijâం & 67.950 .584 & 49.308 .255 & 35.810 .122 & 52.569 .551 & 0,00 \\
\hline Laranja & 6.719 .386 & 5.885 .087 & 5.339 .338 & 5.137 .995 & 5.751 .541 \\
\hline Mandioca & 338.732 .097 & 226.128 .591 & 208.871 .807 & 193.400 .075 & 140.048 .030 \\
\hline Maho & 461.647 .106 & 475.119 .837 & 414.482 .749 & 583.032 .932 & 854.813 .694 \\
\hline Pimenta-do-reino & 2.579 .541 & 750.875 & 0,00 & 0,00 & 0,00 \\
\hline Soja & 1.076 .111 .838 & 992.732 .587 & 1.187 .795 .259 & 1.318 .456 .952 & 1.651 .613 .866 \\
\hline Tomate & 11.324 .317 & 6.864 .484 & 3.875 .904 & 3.959 .781 & 3.731 .673 \\
\hline Uva & 832.462 & 276.133 & 672.207 & 845.915 & 658.435 \\
\hline Bovinos & 5.041 .418 .841 & 6.219 .511 .930 & 6.249 .333 .684 & 6.496 .054 .384 & 7.350 .469 .982 \\
\hline Suinos & 5.702 .295 & 2.833 .980 & 1.921 .016 & 1.579 .997 & 1.741 .750 \\
\hline Frango & 116.509 .390 & 145.691 .497 & $184,389,365$ & 210.000 .232 & 199.788 .326 \\
\hline Peixe & $442,103,47$ & 458.829 .40 & $410,592,00$ & $394,400,00$ & $420.920,00$ \\
\hline Leite & 969.783 .171 & 762.520 .046 & 697.265 .610 & 680.500 .144 & 657.000 .910 \\
\hline Ovos & 36.253 .732 & 29.632 .757 & 20553.764 & 30.218 .869 & 35.841 .058 \\
\hline Total Lav, + Pec. & 10.101 .725 .671 .47 & 11.671607 .934 .40 & $11.091315 .220,00$ & $11.432 .045,067,00$ & 12.857 .570 .531 .00 \\
\hline
\end{tabular}

Fonte: SEAGRI, 2020.

${ }^{10} \mathrm{O}$ Valor Bruto da Produção (VBP) agropecuária representa uma estimativa da geração de renda do meio rural, revertendo em uma variável relevante para acompanhamento do desempenho do setor como um todo. Disponível em:

$<$ http://www.sistemafaemg.org.br/Conteudo.aspx?Code=72\&Portal=2\&ParentCode=67\&ParentPath=None \&Co ntentVersion=R\#: :text=0\%20que $\% 20 \% \mathrm{C} 3 \% \mathrm{~A} 9 \% 3 \mathrm{~A}$, do $\% 20$ setor\%20como\%20um\%20todo >. Acesso em: 05/10/2020. 
Verifica-se, na figura 13, a expansão da produção da pecuária, da soja, bem com o crescimento do café, e se constata uma diminuição na produção do arroz, feijão, banana, entre outros gêneros de primeira necessidade.

A concepção de desenvolvimento que o governo de Rondônia compreende, não coaduna com as concepções consensuadas sobre o que significa desenvolvimento sustentável, ou seja, que deve haver superação das desigualdades regionais, a valorização das culturas, levando em conta a manutenção do ambiente. Assim, como apresentado na figura 13, há um claro incentivo para a produção e expansão do agronegócio.

Natan Costa informa que as secretarias executivas regionais do governo, as quais ele é coordenador, não são ordenadoras de despesa, porém tem funções

[...] principalmente para estabelecer à presença do Governo nas Macrorregiões do Estado, dando suporte as políticas públicas estabelecidas no Plano Plurianual (PPA) de cada Unidade de Execução do Governo, auxiliando na sua implantação, e principalmente cobrando para que a política aconteça $[\ldots]$.

E acrescenta:

Todas as ações são pautadas dentro das 4 diretrizes do Plano de Desenvolvimento Estadual Sustentável (PDES-RO) e são pensadas a partir da Coordenação das Secretarias Executivas Regionais - CSER na SEPOG. Esta coordenação atua para dar logística, suporte, capacitação e criar mecanismos de ação para o fortalecimento de cada Secretaria Regional sendo o elo entre o Governo e a sociedade nos Municípios, atua direcionando as mesmas para auxiliarem ou às vezes protagonizarem as ações agindo como indutoras para a melhoria de cada Região do Estado, buscando solução de conflitos, diminuindo as demandas e vislumbrando oportunidades.

Já com relação à execução do Plano Plurianual (PPA), Pedro Pimentel diz que: "no último PPA do Estado (2016-2019) e suas revisões anuais já foram contemplados as diretrizes e programas do PDES-RO, bem como o atual PPA (2020-2023)" e que

O financiamento do PDES-RO também perpassa diálogos com agências de fomento nacionais: Banco Nacional de Desenvolvimento Econômico e Social (BNDES), Banco do Nordeste do Brasil (BNB) e Banco da Amazônia (BASA), e com instituições executoras de programas setoriais do governo federal.

Para o ex-Coordenador de Desenvolvimento Agropecuário e atual Assessor Técnico da Secretaria de Estado da Agricultura (SEAGRI), Avenilson Gomes da Trindade ${ }^{11}$, o Plano

\footnotetext{
${ }^{11}$ Avenilson Gomes da Trindade, economista formado pela Universidade Federal de Rondônia, ex-Coordenador de Desenvolvimento Agropecuário da Secretaria de Estado da Agricultura (SEAGRI) e atual Assessor Técnico da SEAGRI, a entrevista foi concedida por questionário, devido à pandemia do Covid-19, em 28/9/2020.
} 
de Desenvolvimento Estadual Sustentável (PDES-RO) “[...] é um documento estratégico de referência para o planejamento de longo prazo do estado de Rondônia; sua concepção foi construída a partir da colaboração de vários atores da sociedade e pode ser utilizado pelo setor público e privado". Para ele, é um plano de Estado, estabelecido em Lei a fim de proporcionar o crescimento e desenvolvimento do Estado.

Observa-se que mesmo o governo defendendo que o PDES-RO se constitui como um plano de governo como referência para o processo de construir o desenvolvimento sustentável, os indicadores, como já observado na figura 13, vem de encontro à afirmação, pois o que se verifica é a expansão do agronegócio.

\subsection{SOCIEDADE CIVIL E DESENVOLVIMENTO}

Para o presidente da Federação da Indústria do Estado de Rondônia (FIERO), Marcelo Thomé da Silva de Almeida ${ }^{12}$, ao abordar sobre desenvolvimento sustentável, afirma que essa concepção se deu de forma impositiva no Brasil, pois parte da negação do modelo de produção brasileiro, sem que tivesse, contudo um debate qualificado sobre esse assunto.

Nasceu como uma agenda de confronto, você tem que fazer porque você está errado, porque você tá causando danos ao ambiente. Assim, o empresário do seu lado, enxergou isso como algo como um ataque e não como uma oportunidade. O que percebemos é que nos últimos anos, com o próprio distensionamento por parte do poder público, e de uma nova compreensão do que é efetivamente essa agenda ambiental e de sustentabilidade, é que ao mesmo tempo em que o empresário percebendo, ou melhor, com mudança de hábito do consumidor, com as pressões sobre a forma como se produz, se comercializa e se apresenta o produto. Agora, há a percepção de que a gente precise de uma agenda ambiental que deixa de ser uma agenda impositiva e de comando e controle para ser uma agenda de oportunidade (Sic).

Há que se produzir de forma sustentável e o Estado há que ser parceiro do setor produtivo para encontrar o caminho para essa dita sustentabilidade, porque não vai ser onerando ainda mais o empresário, exigindo que ele cumpra funções que muitas vezes são funções do Estado, em seu lugar, que a gente vai resolver o problema ambiental, pelo contrário, a gente tem produzido.

O desemprego no Brasil, falência das empresas, quebra de diversos setores industriais. Então, precisamos avançar na agenda de conservação, preservação, sustentabilidade, ao mesmo tempo em que se precisa promover a proteção às empresas e a quem produz nesse país, que gera emprego e impostos, e equilibrar essas duas questões, afim de que a gente tenha um caminho que seja sustentável.

\footnotetext{
12 Marcelo Thomé da Silva de Almeida, é graduado em Arquitetura e Urbanismo pela Faculdade de Arquitetura e Urbanismo/URFJ e cursou MBA em Gestão Empresarial, Bussiness Administration and Management, General, na Fundação Getúlio Vargas, atualmente presido a Federação das Indústrias do Estado de Rondônia (FIERO), advindo do Sindicato da Indústria da Construção Civil e do Mobiliário de Porto Velho (SINDUSCON-PVH). Entrevista realizada em fevereiro de 2020, na cidade de Porto Velho-RO.
} 
Verifica-se que é fundamental um planejamento governamental que leve em conta o equilíbrio entre a preservação ambiental e os investimentos da iniciativa privada, deixando de ser uma agenda impositiva do Estado para se construir um ambiente de oportunidades, em parceria com a iniciativa privada.

Para o coordenador do Movimento dos Trabalhadores Rurais Sem Terra (MST) Claudinei Lúcio Soares dos Santos (Tijolão ${ }^{13}$ ), ao abordar sobre o conceito de desenvolvimento sustentável, diz:

Primeiramente temos que contextualizar o termo 'desenvolvimento sustentável', e para isto vou partir de forma telegráfica, dos debates mundiais datados da década de 1970 em diante. O termo surge nas contradições do desenvolvimento do capitalismo, tendo como paradigma a ideia de crescimento econômico e conservação da natureza. Esse debate tem como marco histórico e institucional, a Conferência de Estocolmo de 1972, que teve como tema o meio ambiente humano. O diagnóstico é feito com base em uma sociedade de consumo, que aliena e pilha os bens da natureza, para garantir um modo de vida urbano e industrializada que faz explodir o que se convencionou a chamar de crise ambiental. Mais tarde, vamos ter a ECO-92, e a partir dela, a noção do desenvolvimento sustentável vai se consolidando como caminho de meio, capaz de encontrar a equação da harmonia entre o modo de produção capitalista e conservação da natureza. Mas será com a publicação do relatório da Comissão Mundial sobre o Meio Ambiente e Desenvolvimento Brundtland (1988) chamado de nosso futuro comum que vai disseminar definitivamente o conceito do desenvolvimento sustentável. Por isso, como resposta a questão, não vemos com bons olhos os programas governamentais que se propõem a se desenvolver de forma "sustentável", pois há uma contradição imensa entre as duas palavras desenvolver e preservar. Pois estes programas têm como átomo a realização deste modo capitalista de produção, com uma roupagem de responsabilidade ambiental, ou seja, de forma "menos" impactante na natureza (Sic).

Como se observa na abordagem do líder do MST-RO, a concepção de desenvolvimento sustentável trazida para o Brasil está relacionada à expansão do capital internacional. $\mathrm{O}$ interlocutor entende que os programas governamentais são incapazes de conciliar desenvolvimento e preservação ambiental, pois o modelo capitalista visa à produção com "uma roupagem ambiental", ou seja, se mantém o discurso da preservação.

Pela fala dos dois interlocutores, é possível verificar que existem posições antagônicas, pois para o presidente da FIERO é possível se implantar o desenvolvimento sustentável, avançando na conservação e preservação ambiental e ao mesmo tempo pode-se garantir a expansão de empresas privadas, necessárias para a geração emprego e imposto. Já para o líder do MST, a concepção de desenvolvimento sustentável nasce no seio do

${ }^{13}$ Claudinei Lúcio Soares dos Santos (Tijolão), bacharel em Direito pela a Universidade Estadual de Feira de Santana (UEFS) Bahia. É o coordenador do Movimento dos Trabalhadores sem Terra em Rondônia (MST-RO). Entrevista concedida em fevereiro de 2020 via questionário, devido a Pandemia do Covid-19. 
capitalismo como uma roupagem ambiental para adequar o modo de produção capitalista com a conservação da natureza.

\subsection{AGRONEGÓCIO E AS CADEIAS PRODUTIVAS}

Marcelo Thomé ao abordar sobre as cadeias produtivas enfatiza a agroindústria familiar como elemento essencial de agregação de valor para a pequena e média agricultura. Nesse sentido, destaca:

Existe uma produção agroindustrial com uma escala produtiva pequena que em muitas vezes não atende o mercado local, e que, aliás, isso é uma das formas mais sustentáveis de se produzir. Você reduz deslocamento, você reduz impactos de transporte, enfim. Isso é um modelo equilibrado e sustentável, e que precisa ser fomentado. A agroindústria familiar - a unidade de agricultura familiar - é um modelo que precisa ser preservado, fomentado e estimulado. Penso que é possível harmonizar todas essas possibilidades. Por outro lado, existe uma produção que visa à exportação - a larga exportação -, a larga industrialização com vistas à exportação, mas deve-se observar que se tem um pequeno produtor, você tem um consumo local que precisa ser enxergado e fomentado. E isso é possível por completo ser harmonizado.

O interlocutor defende um modelo em que o pequeno agricultor possa, através de uma agroindústria sustentável, produzir alimentos, visando ao atendimento da sociedade local/regional. Reconhece por outro lado, a existência de uma produção em larga escala, que visa à exportação e explica:

O comportamento econômico de Rondônia é completamente deslocado do restante do Brasil. A gente não vai trazer uma planta da EMBRAER não faz sentido ter produção de avião em Rondônia, mas faz todo sentido ter uma indústria de alimentos fortes que tem a soja e o milho como base. Que tenha essa diversidade de produção de proteína animal como base. Então conjugar, consorciar soja, proteína animal e daqui ter uma produção de alimentos e uma indústria alimentícia forte, isso faz todo o sentido. E esse processo está em curso.

Nessa perspectiva, acrescenta:

[...] se faz necessário organizar uma economia através de cadeias produtivas ainda não estabelecidas no nosso Estado de Rondônia, em especial na bioeconomia, que se pode expandir em diversos setores econômicos ou industriais como, por exemplo, fármacos, cosméticos, resinas, fibras, outras possibilidades (MARCELO THOMÉ).

Observa-se a necessidade de se estabelecer políticas públicas que possam direcionar as adequações com novas cadeias produtivas a partir do material orgânico da região.

As cadeias produtivas estabelecidas no Estado, que nos trouxeram até aqui. Estamos falando da madeira, da pecuária, da agricultura, da produção de 
grãos, da mineração - cadeias produtivas instaladas -, gerando riqueza e emprego, tecnologia, divisas para Rondônia e para todos os Estados Amazônicos.

Como é que a gente continua avançando nessas cadeias produtivas, com o componente da sustentabilidade, hoje permeando a construção dessas soluções. Como é que se evolui na produção de grãos de forma sustentável, sem que isso avance sobre a floresta, como a gente tem experimentado em Rondônia, inclusive com os dados publicado pelo IBGE ou pela CNA em que aumentou a produção de grãos do Brasil, isso vem ocorrendo ano após ano.

Aumenta-se a produção de grãos no Brasil em áreas menores se dá devido o investimento que a indústria vem fazendo em fertilizantes, sementes, implementos agrícolas, a tecnologia que se utiliza no campo, a otimização e o aumento de produção por hectare, como ocorreu nos últimos anos em Rondônia com a correção do solo a partir do uso do calcário. Isso permitiu a reparação de áreas degradadas, produção de grãos em áreas que já eram desmatadas, e isso tem aumentado enormemente a produção de soja e outros grãos em Rondônia. Não por menos, se exportou a partir de Rondônia 15 (quinze) milhões de toneladas de grãos produzidos em Rondônia e Mato Grosso, além de todos os outros produtos que foram escoados pelo Rio Madeira, pela hidrovia do Madeira. Bom, então a gente tem essa agenda de encontrar caminhos sustentáveis para continuar avançando nas cadeias produtivas instaladas no Estado e em toda a região Amazônica.

Faz-se necessário buscar um equilibrar em todas as dimensões envolvendo nesse processo as populações tradicionais, buscar soluções e caminhos para a questão indígena. Aqui se tem outro campo de discussão que é delicado inclusive, que é a mineração em terra indígena (MARCELO THOMÉ).

Para o interlocutor, as cadeias produtivas, para serem eficazes e eficientes, devem utilizar as novas tecnologias para o melhoramento genético, e dessa forma promover aproveitamento das áreas degradadas com reparação do solo, trabalho que pode ser visualizado pela exportação de grãos, e aponta para a necessidade de se abrir o debate da mineração nas terras das populações originárias e tradicionais.

Por outro lado, Daniel Pereira ao analisar sobre a agricultura em Rondônia afirma:

O que está crescendo bastante no estado de Rondônia é a chamada agricultura de alta precisão, ou seja, a agricultura mecanizada deverá estar hoje aproximadamente com 400 mil hectares de lavoura no estado de Rondônia. A agricultura de alta precisão parte de um trabalho de pesquisa da EMBRAPA, em vários de seus campi, principalmente a EMBRAPA no Mato Grosso, desenvolveu um conceito de exploração totalmente diferente do que se vinha praticando anteriormente.

Durante muitos anos, o produtor de carne, não sabia produzir grãos e viceversa, quem produzia grãos não sabia produzir carne. A EMBRAPA desenvolveu um modelo de exploração chamada Consórcio Agro-silvopastoril, em que se explora a pecuária e a agricultura e em muitos dos casos se explora a madeira. Nesse sentido, o estado de Rondônia está caminhando a passos largos para isso. Na região de Vilhena, por exemplo, temos uma expansão de exploração de seiva de madeira de pinos e uma série de outras espécies. Entendemos que em um futuro próximo teremos ali a instalação de 
um polo petroquímico a partir dessas resinas que hoje são vendidos para China.

De acordo com o ex-governador, o estado de Rondônia vem investindo na pesquisa, através da EMBRAPA e da Comissão Executiva do Plano da Lavoura Cacaueira (CEPLAC), para melhorar geneticamente a cadeia produtiva, bem como o grande produtor rural vem investindo nas novas tecnologias do campo. Contudo, não se pode compreender sustentabilidade apenas por implementos de tecnologias no campo, pois o que se observa é que junto com a mecanização da terra e/ou nas distintas cadeias produtivas, se embutem produtos químicos, o que de pronto fogem da concepção de desenvolvimento sustentável e do conceito de uma produção orgânica.

Com relação ao agronegócio, Daniel Pereira frisa que: "Hoje o estado de Rondônia vende carne para pelo menos 40 países diferentes. Vende-se para África, principalmente para os países árabes. Vende-se para quase todos os continentes". Daniel Pereira afirma que Rondônia, pelo tamanho de seu território, “comporta sem agressão os dois tipos de produção: pecuário e soja". Para ele: "As áreas que são ocupadas com bovinocultura tem que ser recuperadas com calcário, tem que se adubadas para poder aumentar a sua produtividade. A extensão deve ser em torno de 5 a 6 milhões de hectares, nessas condições" e acrescenta:

As atividades de agricultura propriamente ditas, somam-se em torno de 400 mil hectares. Nesse sentido se tem uma área de expansão muito grande para o agronegócio, sem conflitar com as áreas de agricultura familiar. O estado de Rondônia é um estado abençoado. Aqui é possível praticar todos os modelos de produção que se queira imaginar. Assim, o papel do estado é cuidar dos menores, regular.

Constata-se que, para o interlocutor, o estado de Rondônia está em uma fase de expansão do agronegócio visando à exportação, e por outro lado, em sua avaliação o governo vem apoiando o pequeno agricultor que não tem os meios de se auto prover, diferentemente da agricultura de precisão que tem condições de se sustentar independentemente do apoio governamental. Porém pode-se dizer que essa concepção expressa pelo ex-governador, não se coaduna com as concepções adotadas pela Agenda 21, visto que tanto a pecuária sem confinamento, quanto a soja, necessitam de grandes áreas para garantir a sua produção.

O estado de Rondônia deve ser compreendido pelo seu processo migratório, pela formação da geografia humana nessa região, em que os trabalhadores que tinham prática de trabalho na agricultura se fixaram a partir da cidade de Ariquemes, seguindo o eixo da BR 364 , enquanto que a migração principalmente do nordeste ficou na capital para desempenhar ações nos serviços públicos. 
Hélio Dias de Souza ${ }^{14}$ presidente da Federação da Agricultura e Pecuária do estado de Rondônia (FAPERON), ao abordar sobre a migração para Rondônia destaca as dificuldades existentes à época em que os trabalhadores que vieram traziam a esperança de crescerem na região chamada "Eldorado do Norte". Além disso, se manifesta sobre a pequena e média propriedade rural, dentro do Programa de Desenvolvimento Sustentável de Rondônia (PDES):

O governo tem um planejamento estratégico sobre políticas públicas para ser implantado no período de 2015 a 2030, entendo que é um marco a ser seguido. No olhar do agronegócio que eu posso fazer uma reflexão sobre o desenvolvimento em Rondônia, sem perder de vista os ciclos econômicos como: o ciclo aí da borracha, o ciclo do minério, madeira etc. A partir do final da década de 1960 e nos anos de 1970/1980, houve uma grande corrida rumo ao chamado o novo Eldorado do Norte. Foi nesse contexto que eu vim em 1982, nessa corrida por terra, eu já estou no terceiro ciclo.

Hélio Dias informa que muitos desses trabalhadores “eram meeiros, arrendatários, pequenos proprietários, outros eram proprietários grandes que queriam crescer ainda mais, comprar mais terras para colocar os filhos para trabalhar [...]". Para ele, "Os desmatamentos muitas vezes ocorreram por desconhecimento técnico, em locais de área de preservação, em Áreas de Preservação Permanente (APP)", e acrescenta: "O lado positivo é que milhares de brasileiros conseguiram o seu pedaço de terra". Com relação à migração, diz ainda:

A migração para Rondônia veio de diferentes regiões do país, estabelecendo
um choque cultural, um choque de conhecimento para os que vieram para cá
como: capixaba, mato-grossense, gaúchos, catarinenses, paranaenses,
paulistas, baianos e de várias regiões do nordeste, mineiros etc. Eu sou do
Mato Grosso do Sul. Essa migração foi extremamente positiva para a região.
Essas expertises, esses conhecimentos proporcionaram o que nós temos hoje
em Rondônia.

Hélio Dias destaca a influência das experiências culturais trazidas de outras regiões para o estado, e dessa forma se configurando na diversidade da produção. Nesse sentido, afirma que Rondônia "hoje possui $85 \%$ da população considerada de agricultores familiares, com 240 hectares para abaixo. Mas se tem uma parcela que é de médio a grandes produtores. Essa diferenciação foi devido ao modelo de colonização implantado na região". Hélio Dias destaca, ainda, o envolvimento das pequenas propriedades em atividades competitivas, devido às adequações das novas tecnologias do campo e diz: "Nós saímos daquele modelo simplório,

\footnotetext{
14 Hélio Dias de Souza, técnico em agropecuária, formado em Pedagogia. Presidente da Federação da Agricultura e Pecuária do Estado de Rondônia (FAPERON). É presidente do Conselho Deliberativo do SENAR/RO e membro efetivo do Conselho Fiscal da Confederação da Agricultura e Pecuária do Brasil (CNABrasil), e Presidente do Serviço Brasileiro às Micro e Pequenas Empresas (SEBRAE). A entrevista foi realizada no mês de fevereiro de 2020, em Porto Velho-RO.
} 
daquele modelo tradicional de cultivo para adoção de tecnologia e inovações em todas as cadeias. E isso agrega renda nas pequenas propriedades. Oxalá que nós continuamos com esses $85 \%$ que se baixar, mas que seja bem devagarzinho".

Camila Markeline da Silva ${ }^{15}$, sobre a mudança de cultura, diz:

Aqueles que vieram para colonizar a região trouxeram suas culturas, suas experiências, ficando difícil uma mudança radical, porém, o que se observa é que as novas gerações já estão sendo formadas com uma nova mentalidade, pensando no futuro do planeta, com a preocupação sobre a proteção ambiental, trazendo a importância da manutenção da água potável, sobre a preservação das matas, preocupação com o trabalho escravo etc.

Verifica-se que Camila da Silva percebe mudanças dos migrantes que vieram trabalhar em Rondônia, visto que as novas gerações já se manifestam preocupadas com o futuro do planeta. Demonstra, ainda, sua preocupação com a preservação ambiental e o desenvolvimento econômico. Em complementação, Zilene Santana Silva Rabelo ${ }^{16}$ afirma:

O governo se propõe a trabalhar com a preservação ambiental, com a prudência ecológica, com a justiça social e com o desenvolvimento econômico. Nesse sentido surge o conflito do poder econômico com a questão ecológica. O poder econômico do agronegócio é muito grande e o poder da agricultura familiar é muito pequeno. Embora os pequenos agricultores estejam recebendo capacitação, chega um momento que o agronegócio está chegando e está comprando as propriedades deles. Se a propriedade dele vale 10 mil e o cara ai oferecem 100 mil, ele vender, e isso já tá acontecendo e então essa família está migrando paras as cidades e para outros estados como Amazonas e Acre. Os plantadores de soja não estão utilizando somente seus pastos, mas estão arrendando e/ou comprando as pequenas propriedades.

Zilene Silva levanta o questionamento sobre os conflitos existentes entre os plantadores de soja, ou do agronegócio, com os pequenos proprietários, que pressionados, ou arrendam ou vendem suas terras, e dessa forma migram para outros Estados. Para ela, o que está em discussão é a força do poder econômico do agronegócio em cima do pequeno agricultor, deixando clara a predominância do capital agrário sobre os pequenos produtores, e assim, não configurando com a concepção de desenvolvimento regional sustentável, visto que o que vem prevalecendo é o grande capital financeiro ligado ao agronegócio.

\footnotetext{
${ }^{15}$ Camila Markeline da Silva - Gerente de Desenvolvimento e Políticas Públicas (GDPP-SEPOG). Entrevista realizada em fevereiro de 2020.

${ }^{16}$ Zilene Santana Silva Rabelo - Graduada em Serviço Social pela Universidade Federal do Maranhão (1984). Coordenou o Plano de Desenvolvimento Estadual Sustentável (PDES), junto à Secretaria de Estado do Planejamento, Orçamento e Gestão (SEPOG). Assessora da Gerência de Desenvolvimento de Políticas Públicas (GDPP-SEPOG). Entrevista realizada em fevereiro de 2020.
} 
Hélio Dias ao analisar as cadeias produtivas, enfatiza a produção do café denominado clonal que devido à pesquisa realizada pela EMBRAPA, houve mudanças genéticas, pois antes se plantava a semente do café e hoje se planta o galho.

Com essa nova tecnologia, o café clonal tem alta produtividade, saindo de 25 sacas por hectare para uma produção acima de 80 e até 120 sacas por hectare, com uma média de 80 sacos por hectare. Essa cadeia vem gerando empregos e renda. Hoje existe uma grande quantidade de famílias envolvidas na cadeia do café.

Hélio Dias também afirma "A cadeia do cacau de 2 (dois) anos para cá vem se consolidando no estado e dessa forma se reinicia uma nova cacauicultura em Rondônia, novas lavouras a base de mudas clonadas". Ele enfatiza que as novas tecnologias do campo, trouxeram alento aos produtores e está despertando uma grande procura para essa cadeia produtiva, e acrescenta: "Hoje Rondônia é o terceiro estado produtor de cacau no Brasil". Outra economia que tem base forte em Rondônia é a pecuária de leite e de corte. "No Brasil [...] se produz 4 (quatro) milhões de litros de leite por dia e em Rondônia se produz 2 (dois) milhões e 200 mil litros por dia. Temos uma capacidade industrial grande e uma produção aquém das necessidades". Contudo, faz observações quanto à baixa produtividade do leite: "Faz-se necessário aprimorar conhecimento e inovação, melhorar a genética do rebanho, melhorar a alimentação e profissionalizar a gestão da propriedade na questão do gado de leite".

Com relação ao gado de corte, Hélio Dias informa que em Rondônia existe um rebando de "10 (dez) milhões de cabeça de gado de corte e 4 (quatro) milhões de gado de leite, ao todo se somando 14 milhões de cabeça de gado" e acrescenta:

A cadeia do gado de corte hoje é a maior cadeia produtiva economicamente no estado, sendo muito significante tanto para o estado, quanto para a classe produtora. Hoje existe em torno de 72 a 76 mil propriedades que trabalham com gado de corte, 32 a 34 mil trabalham com gado de leite. O último censo da Agência de Defesa Sanitária Agrosilvopastoril (IDARON) informa que há em torno de 96 a 100 mil propriedades que trabalham com a pecuária em Rondônia, tanto a de corte quanto a de leite.

E ainda:

Os grandes frigoríficos que trabalham com a exportação de carne, recebem o benefício da Lei Kandir ao venderem carne para outros países como a China e/ou para qualquer outro país; os recursos voltam para os frigoríficos e consequentemente para o bolso desses 72 mil produtores daqui de Rondônia, dessa forma faz com que haja uma distribuição de renda, que hoje movimenta o comércio e prestadores de serviços. Os investimentos se estendem para todas as áreas do comércio. Então, de uma forma indireta, as 
exportações geram benefícios para os produtores que produzem a matéria prima, mesmo ela tendo procedimento industrial (HELIO DIAS).

Daniel Pereira, ex-governador, ao analisar sobre a produção de leite no estado, manifesta:

O estado de Rondônia é o $8^{\circ}$ (oitavo) maior produtor de leite do Brasil e o primeiro da região norte. Precisamos ter na área de laticínio a mesma eficiência técnica que tivemos na área do café. A produtividade do leite ainda é muito baixa. $\mathrm{O}$ valor agregado na produção de leite é praticamente a mesma de 30, 40 anos atrás. Por mais que os governos tenham se esforçado, as pessoas não gostam de sair de sua zona de comodidade.

A melhor produção de leite no Brasil é o estado de Santa Catarina aonde a média de lactação por vaca é de 15 litros, em Rondônia tem-se a média de 5 litros por vaca. Em Santa Catarina, as famílias de trabalhadores rurais que trabalham com leite, se dedicam apenas essa atividade leiteira. O bezerro é abatido imediatamente ao nascimento ou vendido para alguém, assim, a vaca só produz leite. Em Rondônia boa parte do leite produzido vai para o alimento do bezerro. Aqui, as famílias produzem a vaca leiteira, mas também criam o bezerro para a venda, se tirasse o leite do bezerro, a produção de leite subiria para 10 litros por vaca.

Ao comparar com a produção de leite/vaca no estado de Santa Catarina, Daniel Pereira verifica que a produção em Rondônia é muito baixa, porém destaca o trabalho que a Entidade Autárquica de Assistência Técnica e Extensão Rural (EMATER), a Agência de Defesa Sanitária Agrosilvopastoril do Estado (IDARON) e a Federação da Agricultura e Pecuária de Rondônia (FAPERON) vem realizando para melhorar geneticamente o plantel.

A EMATER, o IDARON e a FAPERON estão fazendo um trabalho sistematizado, contratando técnicos especializados visando à melhoria da produtividade de leite do estado. Já se tem em Rondônia uma indústria capaz de processar o dobro da quantidade de leite que se produz hoje. Outro fator que chama atenção é baixo preço do leite no mercado e dessa forma não atrai e ainda inibe os produtores rurais a fazerem investimentos, ao contrário do café que do ponto de vista financeiro é compensador.

Nesse sentido, Daniel Pereira destaca a existência do programa pró-leite criado pelo Conselho Estadual de Desenvolvimento Regional (CONDER).

O pró-leite é uma experiência que está sendo realizado em Colorado d'Oeste, através da EMATER, SEAGRI e IFRO com os empresários locais; as vacas são fertilizadas "in vitro" e isso se constitui a primeira experiência feita em Rondônia para o melhoramento genético com vistas à produção de leite, além desse, existem projetos que são desenvolvidos por empresas privadas que trabalham com laticínios (DANIEL PEREIRA).

Observa-se tanto na fala de Hélio Dias, quanto na fala de Daniel Pereira, o avanço da pecuária, tanto de corte, quanto de leite. Por outro lado, deve se considerar que a produção de 
leite/vaca é baixa, e devido o gado ser tratado em campo aberto necessita de uma área grande para pastagem, resultando no desmatamento.

Figura 14 -Rebando de corte e leite em Rondônia (2019)

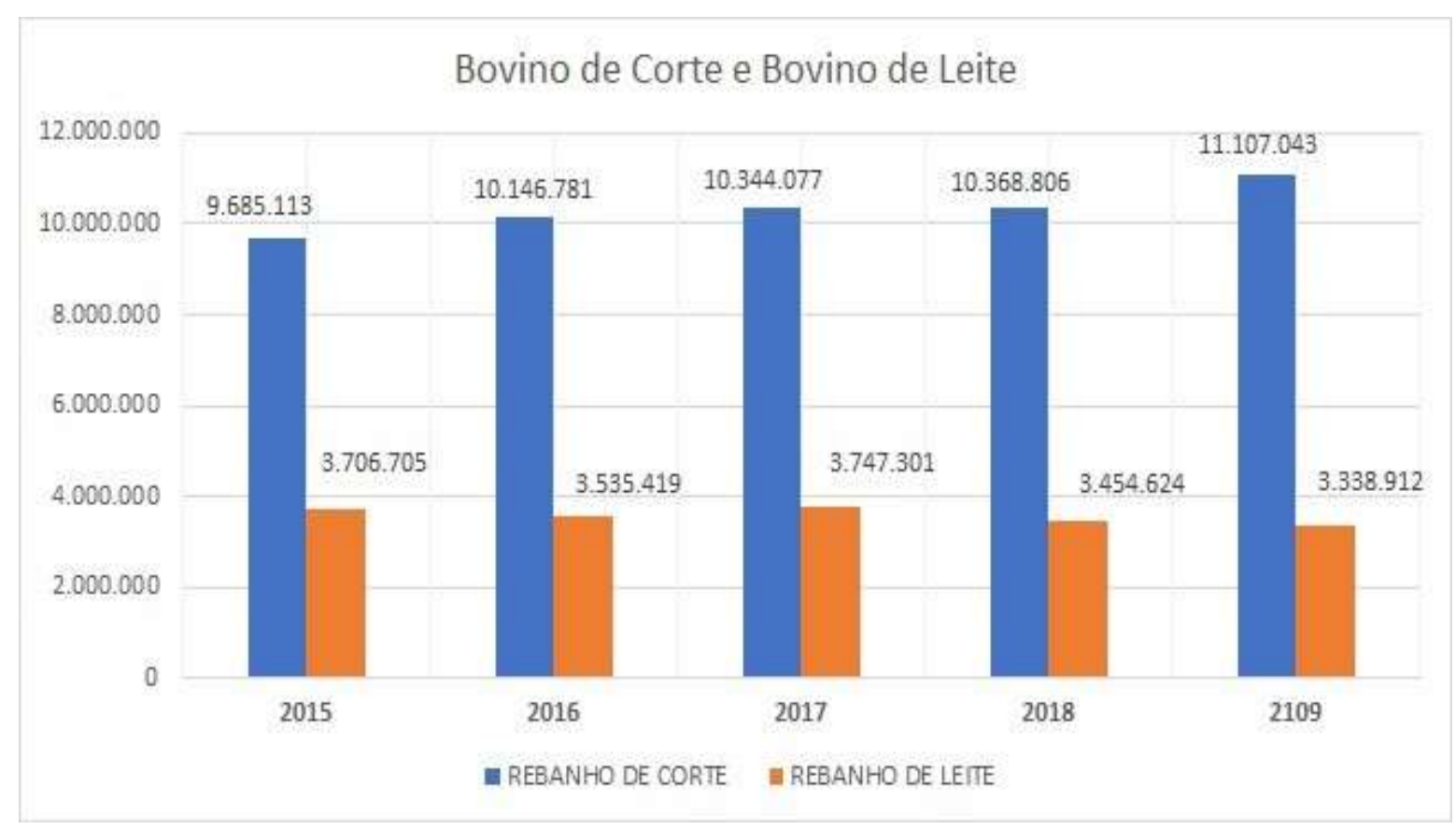

Fonte: construído a partir dos dados da SEAGRI, 2020 - Ref. IBGE.

Observa-se, conforme dados da Agência de Defesa Sanitária Agrosilvopastoril do Estado de Rondônia (IDARON), que o agronegócio está em fase de expansão, principalmente com a pecuária de corte e de grãos como a soja e milho, além do café. Conforme figura 14, em 2019, havia um rebanho bovino de corte de 11.017.043, representando 77\% e 3.338.912, de gado de leite, representando $23 \%$, somando um total 14.355 .955 de cabeças de gado, o que coaduna com as informações do presidente da FAPERON da existência de 14 milhões de cabeças de gado. Contudo verifica-se a partir dos dados contidos na Guia de Trânsito Animal (GTA), de julho de 2020 da IDARON ${ }^{17}$, que houve um decréscimo no rebanho para 13.510.913 cabeça de gado.

Em matéria publicada no site da Secretaria de Estado da Agricultura (SEAGRI ${ }^{18}$ ), referindo-se ao gado de leite, Evandro Padovani, secretário da Agricultura, diz: "Hoje somos o primeiro maior produtor de leite da Região Norte, o oitavo do Brasil. Temos uma genética boa, mas nos importamos com a alimentação bovina, trabalhando a pastagem com o calcário,

${ }^{17}$ Cf. http://www.idaron.ro.gov.br/wp-content/uploads/2020/08/REBANHO-POR-MUN\%C3\%8DCIPIO.pdf. Acesso em: $05 / 10 / 2020$.

18 "Secretaria de Agricultura destaca o desenvolvimento das cadeias produtivas prioritárias de Rondônia". Disponível. $<$ http://www.rondonia.ro.gov.br/secretaria-de-agricultura-destaca-o-desenvolvimento-das-cadeias-produtivas-prioritarias-derondonia/ Acessado em: 19.10.2020. 
adubação, pasto rotacionado, higienização da ordenha”. Conforme matéria publicada no site da SEAGRI com o título "Secretaria de Agricultura destaca o desenvolvimento das cadeias produtivas prioritárias de Rondônia”, em 2019 afirma:

A pecuária de corte, carro-chefe da produção, corresponde a $23 \%$ do PIB (Produto Interno Bruto) do Estado. Com a preocupação de atender aos protocolos internacionais que o mercado exige sobre a qualidade da carne, Rondônia se adéqua para a produção dos pecuaristas, em parceria com o Ministério da Agricultura, Pecuária e Abastecimento, Idaron e câmaras setoriais. No ranking de exportação nacional e internacional, o Estado se destaca com a pecuária de corte, onde $80 \%$ da carne é consumida no Brasil e $20 \%$ exportado, como o $6^{\circ}$ maior rebanho do país e $4^{\circ}$ maior exportador, atendendo a mais de 40 países e buscando a participação do mercado europeu.

Com relação soja, a matéria oficial supramencionada informa que a soja ocupa,

270 mil hectares de área, e influencia na renovação das áreas degradas pela pastagem, recuperando o solo. Também de grande importância para a utilização da proteína animal, assim como o milho, como ração de bovinocultura de corte, bovinocultura de leite, piscicultura, suinocultura e avicultura.

Padovani acrescenta dizendo que: "Produtos que temos que ter em produção em grande escala, para um custo menor, porque reflete na base alimentar de outras cadeias produtivas". A soja produzida em Rondônia está sendo exportada "in natura", visto que somente existe uma indústria de médio porte, o que não permite a transformação para ser utilizado na base alimentar.

Figura 15 - Produção de soja em Rondônia

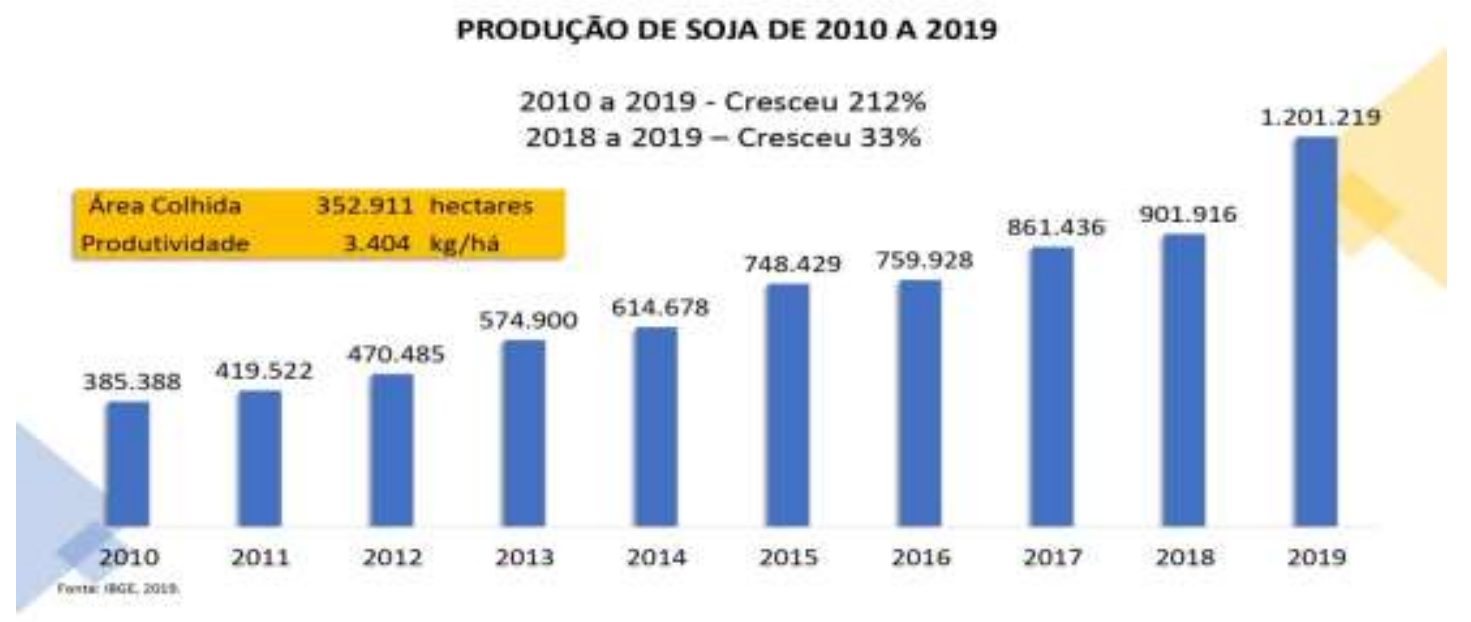

Fonte: SEAGRI, 2020. 
Observa-se, conforme a Figura 15, o crescimento da produção de soja em Rondônia. Nesse sentido, Hélio Dias afirma que "é uma cadeia produtiva estratégica do ponto de vista econômico e ninguém segura a cadeia de grãos" e acrescenta dizendo:

Hoje se estima que exista em torno de 380 a 400 mil hectares de soja plantada nessa safra 2020. Além da soja, acreditamos que o milho da chamada safrinha deve chegar em torno de 150 a 180 mil toneladas; $40 \%$ da área plantada de soja entram como "milho safrinha", ou seja, no intervalo da produção da soja, se planta e colhe o milho. Esse crescimento vai continuar por causa dos preços que são vantajosos para a exportação da soja, devido às commodities e s valorização do dólar ajudando entre outras questões.

Como se observa, existe um consórcio na produção de grãos, ou seja, soja e milho em que Hélio Dias está chamando de safrinha, ou seja, se produz na entressafra da soja. Nesse sentido, pode-se ilustrar o crescimento dessa cadeia produtiva.

Figura 16 - Produção de milho em RO

PRODUÇÃO DE MILHO EM RONDÔNIA (TONELADAS)

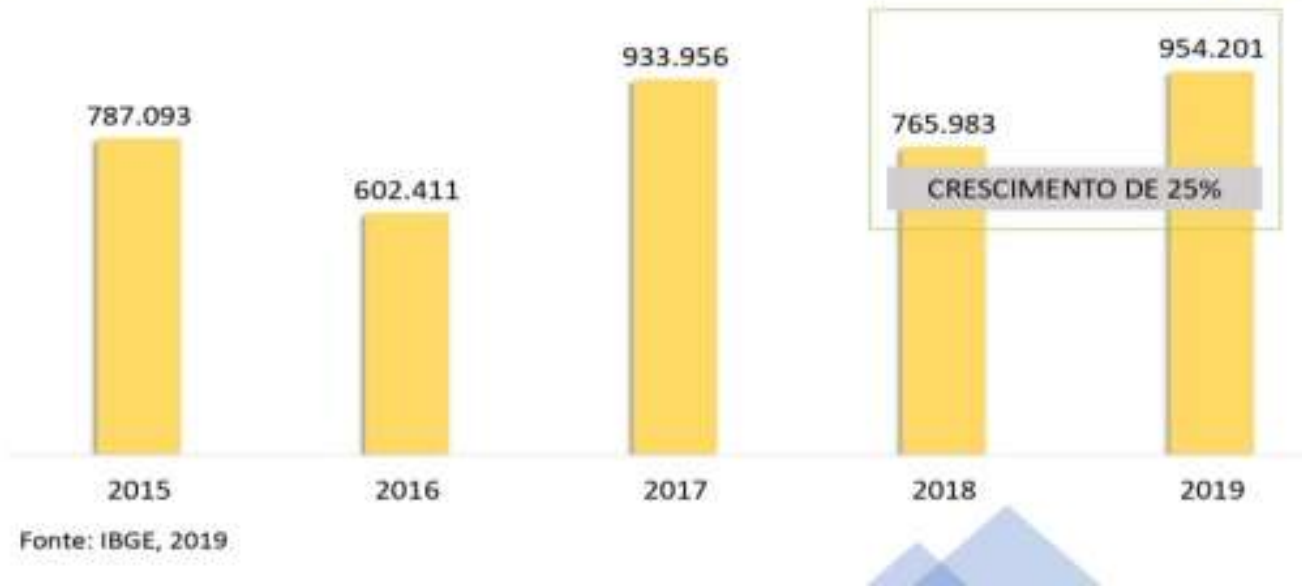

Aqui se percebe, conforme Figura 16, que há um forte crescimento na produção do milho, como já mencionado, oriundo da entressafra da soja.

Com relação à exportação, Hélio Dias referindo-se as commodities enfatiza que existe uma logística em Rondônia como o porto graneleiro localizado em de Porto Velho, e acrescenta "O porto graneleiro em Porto Velho, no Rio Madeira, possibilita o escoamento para os portos de Itaquatiara-Am e Santarém-Pa, e de lá para outras paragens" (HELIO DIAS).

Avenilson da Trindade acrescenta que Rondônia tem se estabelecido como um importante produtor de alimentos: 
Rondônia tem conseguido bons resultados em um cenário com os dois setores, como os médios e grandes são mais capitalizados, demandam menos política pública de apoio e insere muita tecnologia de ponta, o que melhora o nível tecnológico de produção, já a agricultura familiar, mais presente no rol das políticas públicas, exercem papel preponderante para o atendimento do mercado interno estando presente de forma significativa na alimentação da população.

E ainda,

Esse crescimento é resultado da maturidade tanto das instituições que atuam no setor, quanto da expansão do conhecimento do próprio produtor, disponibilidade de crédito rural e diversidade de cadeias produtivas que contemplam do pequeno ao grande produtor [...] o governo tem investido em políticas públicas para a agricultura familiar, com fomento, assistência técnica, microcrédito, transferência de tecnologias e ambientes de comercialização da produção, e os resultados se apresentam na melhoria dos indicadores de produção (AVENIL GOMES DA TRINDADE).

Como se observa na afirmação de Avenilson Trindade, Rondônia tem conseguido bons resultados tanto com o grande capital, quanto com o médio e pequeno produtor que necessitam de apoio do governo. Também destaca que o estado tem "se estabelecido como importante produtor agropecuário, as condições locais vão se apresentando cada vez mais adequadas para ampliação das cadeias produtivas com aumento de tecnologia" e em sua avaliação, "O mercado local absorve bem a produção interna, o que torna o setor produtivo interessante do ponto de vista econômico".

Deve-se registrar, por outro lado, que o governador Marcos Rocha, em junho de 2019, lançou o Programa Estadual de Aquisição de Alimentos (PAA) com o objetivo de fortalecer a agricultura familiar. Esse programa visa trabalhar com a

modalidade de compra direta dos produtores rurais de aves, carnes, pescados, leite, ovos, mel, doces, massas, pães, frutas, polpas, grãos, cereais, raízes e tubérculos. Ao mesmo tempo em que o governo adquire esses produtos, eles já são simultaneamente doados para associações que atendam pessoas em situação de insegurança alimentar ${ }^{19}$.

Com relação às cadeias produtivas e sua relação com agronegócio, Avenilson Trindade diz:

Rondônia apesar de ter uma participação importante no agronegócio brasileiro, ainda está em consolidação, há cadeias produtivas em crescimento, como grãos, outras em redução, como feijão e banana. Também há outras sendo estimuladas, como as agroindústrias. Porém, foi feito

\footnotetext{
${ }^{19} \mathrm{Cf}$. Programa Estadual de Aquisição de Alimentos é lançado para fortalecer agricultura familiar e combater a fome em Rondônia. Disponível em: < http://www.rondonia.ro.gov.br/programa-estadual-deaquisicao-de-alimentos-e-lancado-para-fortalecer-agricultura-familiar-e-combater-a-fome-em-rondonia/>. Acesso em: 05/10/2020.
} 
investimentos na ordem de $\mathrm{R} \$ 170$ milhões em mecanização onde os municípios receberam equipamentos agrícolas para atuarem na agricultura familiar e diversos outros programas estão focados na agricultura familiar, o que certamente promoverá o fortalecimento de diversas cadeias produtivos que estão relacionadas à produção de alimentos diretos ao consumidor. Já que os médios e grandes produtores estão mais focados na exportação, como soja e carne bovina.

Aqui verifica-se que há um crescimento do agronegócio em Rondônia, com investimento do governo para auxiliar os municípios, e dessa forma oferecer condições para que os pequenos agricultores possam fortalecer as cadeias produtivas regionais.

Outro fator que se deve levar em conta em Rondônia é o investimento na cadeia produtiva de peixe nativo amazônico, como o tambaqui e o pirarucu. A ameaça da extinção da pesca artesanal, bem como o aumento da população brasileira e, sobretudo da população regional, habituada a se alimentar desses pescados, despertou o investimento na criação de peixe de cativeiro na região central do estado, com destaque para a região do Vale do Jamari, cuja cidade referencial é Ariquemes.

Maeante e Dória (2018, p. 168) ao abordarem sobre essa cadeia produtiva, dizem:

A aquicultura moderna está embasada em três pilares: a produção lucrativa, a preservação do meio ambiente e o desenvolvimento social. Os três componentes são essenciais e indissociáveis para uma atividade perene. A produção deve ser encarada como um processo que envolve toda a cadeia produtiva, visto que cada elemento que a compõe tem seu papel, razão pela qual qualquer elo fraco limitará o desenvolvimento da atividade.

Nessa perspectiva deve se levar em conta não somente a questão lucrativa, mas a preservação do ambiente, sobretudo porque o peixe necessita para se desenvolver, água limpa e que garanta o equilíbrio ecológico para a sua sobrevivência.

Figura 17 - Polos produtores de pescado na região

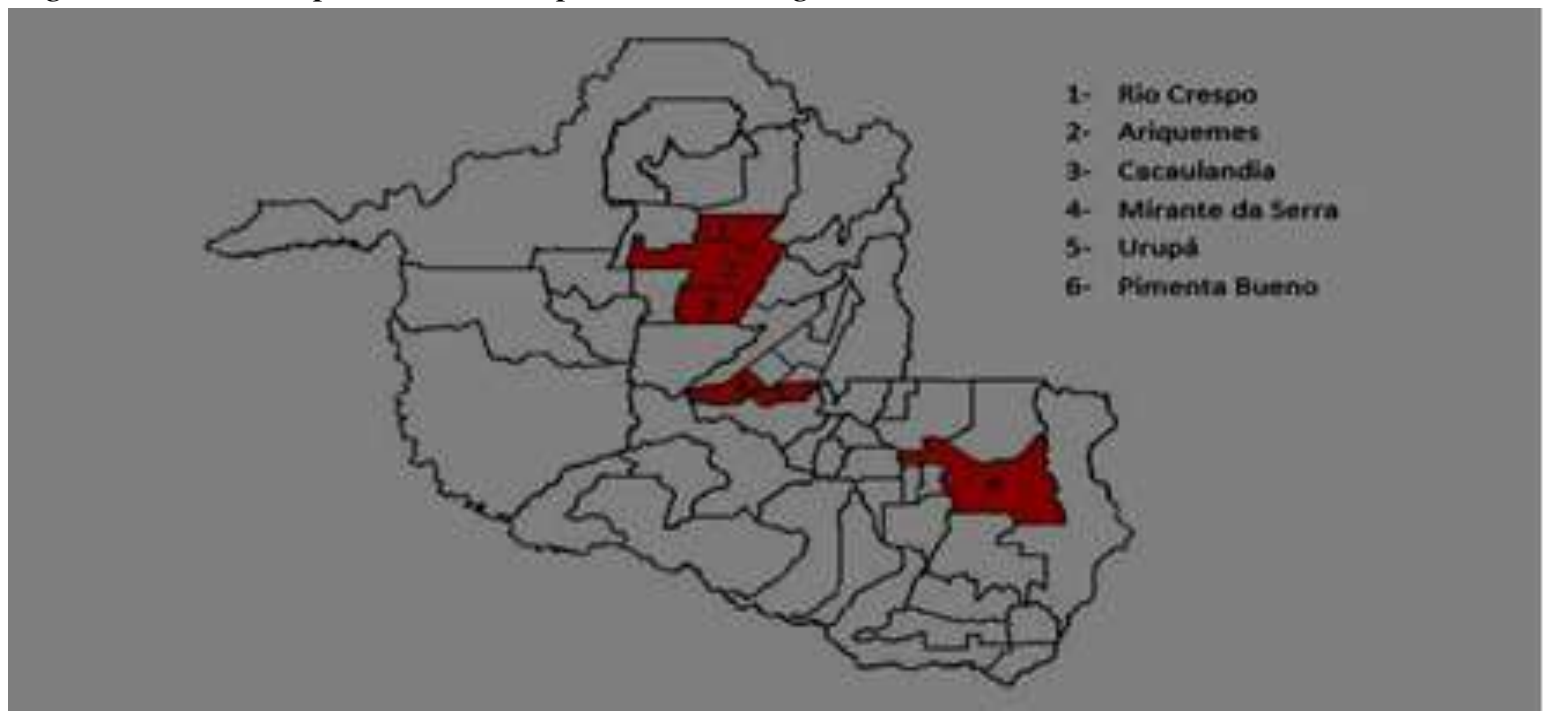

Fonte: MEANTE e DORIA (2018). 
Analisando a produção nesses polos, Meante e Doria (2018, p.175) expõem: “A produção do pescado no estado de Rondônia é praticada em viveiros escavados, semiescavados e do tipo barragem aproveitando o potencial hídrico da região" e acrescentam:

Esta produção está baseada em sistemas semi-intensivos de produção com o sistema de recria e engorda na qual os alevinos são estocados em altas densidades em viveiros menores e depois são transferidos para viveiros maiores com melhor qualidade de água, menor densidade e maiores taxas de arraçoamento.

Figura 18 - Produção de peixe nativo em cativeiro

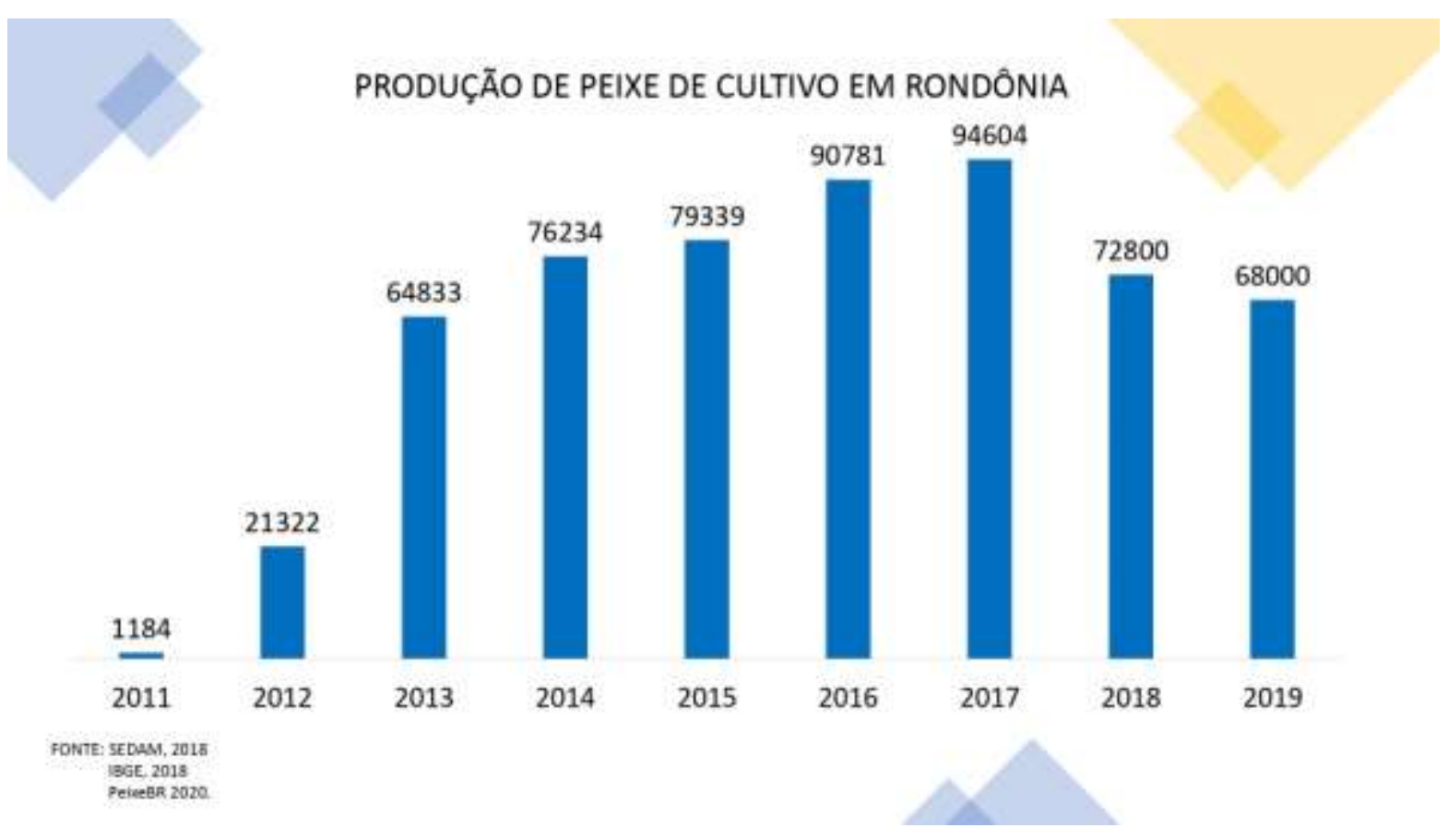

Como se pode verificar na Figura 17, houve um crescimento na produção de pescado na região, com uma diminuição no ano de 2019. A exportação desse pescado está sendo realizada para várias regiões brasileiras, porém acentuada para a região Amazônica, além da exportação para o exterior.

Segundo dados da SEDAM, "O Estado possui 4.308 empreendimentos cadastrados e licenciados exclusivamente para comercialização e produção, ocupando uma área de 15.810,26 hectares de espelho d'água, com uma projeção de produção de 95.534,37 toneladas ao ano". E ainda: "As exportações de peixe do estado de Rondônia tiveram início em 2017 com destino ao Vietnã [...] Em 2019, de janeiro a junho já foram exportados mais de 259 toneladas de peixe para o Peru, Bolívia e Estados" ${ }^{20}$.

\footnotetext{
${ }^{20} \mathrm{Cf}$. http://www.rondonia.ro.gov.br/capacidade-de-producao-da-piscicultura-em-rondonia-cresceu-863segundo-dados-da-
} 
Lázaro Aparecido Dobri (Lazinho da FETAGRO ${ }^{21}$ ), sobre o crescimento do agronegócio em Rondônia, enfatiza que esse modelo segue "uma tendência normal de crescimento em Rondônia. Por ser um estado que oferece todas as condições necessárias para o modelo de produção. Terras baratas, concentração de terras, apoio do governo". Essa condição peculiar em RO demonstra uma tendência de não ter desenvolvimento e sim concentração de renda. Por outro lado, analisa que é possível conciliar a expansão do agronegócio com a agricultura familiar "basta o governo e o poder público em geral querer. Se a nossa produção for apoiada e incentivada levando em consideração nossa geografia é possível, pois temos regiões que é mais propício para agricultura familiar”.

Quadro 7 - Amazônia em conflito no campo 2015 a 2017

\begin{tabular}{|l|c|c|c|c|c|}
\hline Estado & $\mathbf{2 0 1 5}$ & $\mathbf{2 0 1 6}$ & $\mathbf{2 0 1 7}$ & Total & \% \\
\hline Rondônia & 20 & 21 & 15 & 56 & 38,9 \\
\hline Pará & 19 & 6 & 20 & 45 & 31,3 \\
\hline Maranhã & 6 & 13 & 5 & 24 & 16,7 \\
\hline Mato Grosso & 1 & 2 & 9 & 12 & 8,4 \\
\hline Tocantins & & 3 & & 3 & 2 \\
\hline Amazonas & 1 & 2 & & 3 & 2 \\
\hline Roraima & & 1 & & 1 & 0,7 \\
\hline Amapá & & & & & \\
\hline Acre & & & & & 100 \\
\hline Total Amazônia & 47 & 48 & 49 & 144 & 100 \\
\hline Total Brasil & 50 & 61 & 59 & 170 & \\
\hline
\end{tabular}

Fonte: Atlas de Conflitos na Amazônia - CPT - set. 2017

Como se pode observar no quadro 7, no período de 2015 a 2017 Rondônia figura como o maior percentual de morte em conflito no campo na Amazônia, somando 38,9\%. Sobre esse assunto, Lazinho da Fetagro afirma:

A forma de distribuição de terras no Brasil sempre foi injusta e em Rondônia não é diferente. Rondônia tem o crescimento do agronegócio muito forte e isso valoriza as terras que antes eram abandonadas e ocupadas por terceiros, agora, eles voltam e requer na justiça o suposto patrimônio que no passado não cumpriu com as cláusulas de contrato. E a falta de regularização fundiária causa também conflitos.

sedam/\#: :text=Nos\%20\%C3\%BAltimos\%20tr\%C3\%AAs\%20anos\%20segundo,2016\%20para\%2015.800\%20e m\%202018>. Acesso em: 05/10/2020.

21 Lázaro Aparecido Dobri (Lazinho da FETAGRO), foi presidente da Federação dos Trabalhadores na Agricultura de Rondônia (FETAGRO), é deputado estado em Rondônia pelo Partido dos Trabalhadores (PT), Entrevista realizada no mês de setembro de 2020, via questionário, devido à pandemia do Covid-19. 
Lazinho da Fetagro e Maria Petronila Neto $^{22}$ (CPT) concordam que uma das causas dos conflitos no campo em Rondônia é relacionada aos primeiros migrantes que receberam grandes lotes de terras para produzir café ou cacau, e assinaram um contrato com o INCRA, porém com o decorrer do tempo transformaram as áreas em pastos e desviaram-se do compromisso assinado, proporcionando a ocupação por outros migrantes sem terras. Outro fator se relaciona a grilagem de terra e invasão em áreas de reservas.

Com relação ao apoio do governo a pequena e média agricultura, ou agricultura familiar, objetivando a fixação dos trabalhadores no campo, Lazinho da Fetagro diz que "O governo tem muito discurso e pouca prática". Constata-se que existe uma emigração para outros estados como Amazonas e Acre, e nesse sentido, o interlocutor afirma que "o crescimento no agronegócio empurra principalmente o pequeno produtor para abrir novas fronteiras".

Com relação transferência de novas tecnologias para os pequenos agricultores, Lazinho da FETRAGRO analisa como sendo uma questão cultural, devido à migração de várias regiões do Brasil e destaca:

Existem algumas iniciativas por parte de pequenos grupos de produtores, mas, o cooperativismo depende muito mais da consciência do que de incentivo. Nosso estado tem uma população ainda oriunda de vários estados com culturas diferentes que prejudica a organização [...] nesse sentido é muito difícil organizar os produtores em associações e cooperativas.

Com relação ao processo de expansão do agronegócio na região, Claudinei (Tijolão) relaciona que o processo migratório para o estado de Rondônia se deu por definição de políticas externas, como espaço atrativo do ponto de vista econômico e buscando estimular o agronegócio na região e diz:

O agronegócio em Rondônia é parte destes ciclos de expansão do capital. Ele se estrutura no estado no final dos anos 1990 e início de 2000, fazendo parte da reorganização na agricultura, tendo nas medias e grandes propriedades seu espaço de territorialização. Suas principais atividades estão ancoradas na produção de soja (cone-sul e norte do estado). Segundo o levantamento feito pela Companhia Nacional de Abastecimento (CONAB), a produção de soja em Rondônia [...] será a mesma do ano passado, cerca de 1,094 milhão toneladas numa área de 333.600 mil hectares. As exportações de soja e milho somadas representaram US $\$ 150$ milhões (Conab, 2019), e gado de corte está presente em todo o estado sendo atividades de pequenas, medias e grandes propriedades, com rebanho de 14 milhões de cabeças

\footnotetext{
22 Maria Petronila Neto, agente de Pastoral, foi coordenação da Comissão Pastoral da Terra (CPT-RO) no período de 2013 a 2019, atualmente faz parte do setor de comunicação e informação na CPT. Entrevista realizada em fevereiro de 2020, na cidade de Porto Velho-RO.
} 
(IDARON, 2017). Mais este processo de expansão do capital na agricultura, chega ao seu limite sobre as terras agricultáveis no final dos anos 2000. Isto justifica o aumento da grilagem e desmatamento da terra. E com a crise financeira de 2008, o agronegócio e o capital financeiro vão se apropriar de outros bens da natureza como água, terra e minério para obter uma extraordinária taxa de lucro $($ Sic $)$.

Ao abordar sobre o agronegócio na região, o interlocutor enfatiza a existência de 10 (dez) acampamentos em conflitos em Rondônia com famílias morando embaixo da lona em tempo igual ou a superior a 10 anos. "Um deles, por exemplo, é o acampamento Che Guevara em Alto Alegre dos Parecis, que ocupa uma área da família Morimoto, vai fazer 28 anos em setembro deste ano". Assim os conflitos estão relacionados com a falta de regularização fundiária.

Não temos um programa de Estado para assentar as famílias que queiram trabalhar na terra; nunca foi feito este levantamento de forma especifica em Rondônia. Mas posso afirmar que se partirmos da ideia da regularização fundiária do estado, englobando aqui, sem-terra, ribeirinhos, quilombo e indígena, teremos dezenas de famílias em conflito (CLAUDINEI (TIJOLÃO).

Para Claudinei (Tijolão), o governo federal, além de não ter uma política voltada para a regularização das terras no estado, vem sistematicamente diminuindo o número de pessoal que trabalhava no INCRA e diz que:

[...] Rondônia tinha o segundo maior número de funcionários do Brasil, com 450 pessoas, só perdia para o INCRA do Rio de Janeiro, isto até final dos anos 2000. Com a reforma de previdência e o desmente que o governo Bolsonaro vem fazendo, as previsões segundo cálculos da Associação dos Servidores do INCRA (ASSINCRA), é que vamos chegar ao final de 2020 com 84 funcionários.

Com relação à expansão do agronegócio em Rondônia, Maria Petronila Neto, excoordenadora da CPT-RO, diz:

Temos uma radicalidade em relação ao agronegócio, visto que não traz nenhum benefício para os pequenos agricultores que inclusive são os que colocam o alimento nas nossas mesas. O agronegócio é um mal porque não traz uma diversidade de agricultura, mas, somente o monocultivo de alguma produção rural. Pode até ser plantio de mandioca, porém, dentro da metodologia do agronegócio a sua produção visa o atendimento do mercado externo, o produtor pode até plantar mandioca, a mesma mandioca cultivada pela agricultura familiar, porém, o seu destino é a exportação.

A fala de Maria Petronila Neta demonstra que o governo do estado apoia o agronegócio e acrescenta: 
O governo não oferece capacitação no campo para os pequenos agricultores, além da falta de políticas públicas como escola, postos de saúde, lazer etc. Não tendo essas políticas, as famílias e principalmente os jovens são obrigados a saírem da roça para estudar nas cidades e com isso vem prejudicando a fixação no campo.

Como se percebe, o crescimento do agronegócio tem levado uma migração interna para outros estados visto que devido à falta de política governamental de apoio ao pequeno agricultor através de suporte técnico, esses estão vendendo suas terras e migrando para outros estados da região.

A manifestação da representante da CPT deixa claro de que o governo vem assumindo posição ao grande capital, pois além de não possibilitar ao pequeno e médio agricultor o acesso às tecnologias para melhorar a sua produção, nem oferecer condições sociais para o campo, estimula o agronegócio, porém mantendo o discurso do desenvolvimento regional sustentável.

\subsection{QUESTÕES INDÍGENAS E OS IMPACTOS AMBIENTAIS}

Dom Roque Paloschi ${ }^{23}$, ao ser abordado sobre a concepção de desenvolvimento, se manifesta:

$\mathrm{Na}$ minha concepção, desenvolvimento sustentável é, sobretudo saber conviver com as potencialidades naturais da região, sabendo valorizar as experiências dos povos dessa região, e construindo projetos aonde eles não são importados de fora, mas construídos a partir também, dos saberes populares, da sabedoria popular. O desenvolvimento sustentável é aquele que ajuda as pessoas a viverem em harmonia, também como a criação. Hoje nós estamos numa encruzilhada perigosa, na medida em que vamos à ânsia de ocupar a Amazônia, vamos desmatando, vamos queimando, vamos poluindo a terra, as águas, os rios, os lagos, mas também o ar. Então nós vivemos assim esse dilema. Aonde se acha que é preciso explorar o máximo dos recursos da natureza, levando assim ao esgotamento. O desenvolvimento sustentável é aquele desenvolvimento de que é capaz de valorizar as experiências locais, os saberes locais, e que dá condições das pessoas viverem com dignidade. Porque nós vivemos também na ambição do acumular. Poucos têm muito e muitos não têm nada. Na expressão do famoso escritor gaúcho Erico Veríssimo, o gaúcho morre do mesmo problema, todos os gaúchos morrem do mesmo problema - a barriga. Uns porque comem demais e outros porque não comem. Essa está sendo mais ou menos a realidade nossa também aqui no Brasil e no mundo, e também em Rondônia, onde a concentração da terra está ficando em poucas mãos. As pequenas propriedades não encontram apoio para proteger o alimento e também os povos - os ribeirinhos, os povos indígenas, povos quilombolas -,

${ }^{23}$ Dom Roque Paloschi, presidente Nacional do Conselho Indigenista Missionário (CIMI) e Arcebispo da Arquidiocese de Porto Velho - Rondônia. Entrevista realizada em fevereiro de 2020, na cidade de Porto VelhoRO. 
praticamente não tem apoio nenhum para desenvolver projetos de autos sustentação em harmonia com a natureza $($ Sic $)$.

Observa-se que Dom Roque concebe o desenvolvimento sustentável como sendo um espaço de convivência harmônica dos seres humanos com a natureza. Também destaca que os projetos políticos devam levar em conta as particularidades regionais/locais, as experiências acumuladas dos saberes dos povos, de acordo com cada cultura. Destaca a preocupação que na busca da ocupação da Amazônia, se polui e destrói a natureza comum, como a terra, a água, os rios e o ar.

Com relação aos conflitos existentes na região que envolve as populações originárias e tradicionais, bem como aos pequenos agricultores e a expansão do agronegócio em Rondônia, Dom Roque diz:

É lamentável porque nós temos no Brasil, tantas Universidades públicas que formam veterinários, formam agrônomos, e depois o pequeno agricultor não tem apoio de um veterinário ou agrônomo para poder levar para frente projetos de redimensionamento de diversificação da pequena propriedade, reduzido muitas vezes à pequena propriedade a uma sobrevivência muito sofrida. Esse conflito cresce porque a força do agronegócio vai chegando e muitas famílias aqui dos municípios que compreende a diocese de Porto Velho, estão arrendando as suas terras por um valor relativamente significativo para elas, mas que depois de 8,10 anos, recebem essas terras totalmente sugadas. Isso de tudo é um caminho para se repensar o nosso planeta - desta casa comum -, com na expressão do Papa Francisco, na LAUDATO $S I^{24}$. Então, esse é o grande dilema, acha-se que os recursos naturais não têm limites, pelo contrário, eles têm limites, são finitos; segundo, nós achamos que podemos explorar o máximo.

Segundo pesquisas de centros reconhecidos demonstram que o ritmo que nós vamos, vamos criar uma região de savana já, nesta bela e pomposa região amazônica por causa do desmatamento sem critério que está acontecendo. $\mathrm{O}$ número de igarapés que vem secando nos últimos anos é muito grande em todo o estado de Rondônia, e isso é preocupante porque é sinal de que nós não soubemos respeitar limites. O uso indiscriminado do fogo que nós alimentamos isso também é um problema sério. Então, aonde nós vamos chegar com tudo isso? O conflito cresce na medida em que não se estabelece parâmetros. $O$ que é verdadeiramente importante definir para o desenvolvimento de Rondônia? E nós sabemos que quem põe a comida na mesa das famílias brasileiras são as pequenas propriedades rurais, mas são cada vez mais sucateadas e mais desprezadas e abandonadas pelo próprio governo que está preocupado em produzir commodities para exportar para pagar a divida externa. Nós nos tornamos um país colônia que produz commodities pra exportar, seja o milho, seja a soja, seja a cana-de-açúcar, ou seja, minérios. Então é difícil! Esse conflito cresce muito, e os dados da violência no campo são irrefutáveis e não são frutos do acaso, não são frutos de espíritos que vem do além, são frutos de uma ambição gananciosa, alimentada também por parte dos governos (Sic).

\footnotetext{
${ }^{24}$ Laudata si - É a primeira Encíclica do Papa Francisco, publicada em 2015 e que trata sobre o consumismo, desenvolvimento irresponsável e as mudanças climáticas no planeta. Em português significa "sobre o cuidado da casa comum".
} 
Nessa manifestação, pode se observar que sua ênfase se refere aos parâmetros estabelecidos pelo governo, deixando claro em sua análise que os governos vêm privilegiando e apoiando políticas para produção de commodities sem levar em conta que é a pequena agricultura responsável para abastecer os mercados locais. Outro fator que deve ser levado em consideração diz respeito ao ingresso de indígenas na produção de café, denominado clonal, em grande escala visando à exportação.

Dom Roque, demostra preocupação com o futuro dos povos originários e tradicionais na região no que se refere a produção de agricultura para exportação, contudo manifesta respeito nas decisões dentro do processo histórico.

Dom Roque Paloschi, ao se manifestar sobre as questões indígenas na região Amazônica e nessa perspectiva inclui as etnias ameaçadas em Rondônia ao jornalista João Vitor Santos ${ }^{25}$, do Instituto Humana Unisinos, vai dizer:

A principal preocupação e ameaças com relação aos povos indígenas é que garimpeiros, grileiros, madeireiros e invasores em geral, não fazem a quarentena. Ao contrário, aproveitam a falta de fiscalização e de gestão política e administrativa no país para continuar com as ações ilícitas nas terras indígenas, com um agravante maior, os contínuos discursos do governo do Brasil em incentivar as invasões, com sua retórica desenvolvimentista. Outra grande preocupação são os projetos de emenda constitucional e projetos de lei, como o PL 191/20, que regulamenta a exploração de recursos minerais, hídricos e orgânicos em reservas indígenas. (DOM ROQUE PALOSCHI)

Dom Roque Paloschi, analisa, ainda, sobre o processo histórico que vivem os indígenas na região Amazônica afirma: "Os povos indígenas vivem uma situação de total violência e violações de direitos pela ausência do Estado brasileiro e sua ineficácia em coibir os atos ilícitos de invasões e desconstituição dos artigos 231 e 232 da Constituição Federal". Além disso, discorre sobre os ataques que vem sofrendo as populações originárias e diz que essa posição "[...] coloca em risco a integridade física, cultural e territórios dos povos e, consequentemente, compromete diretamente o modo próprio de vida dos povos indígenas". Sobre o cenário que o Brasil passa na atualidade, sobretudo referente às violações dos direitos dos povos indígenas, destaca Dom Roque Paloschi:

\footnotetext{
${ }^{25}$ Cf. SANTOS, João Vitor. Garimpeiros, grileiros e madeireiros não fazem quarentena e avançam sobre a floresta e povos indígenas. Entrevista especial com Dom Roque Paloschi <http://www.ihu.unisinos.br/159noticias/entrevistas/598636-garimpeiros-grileiros-e-madeireiros-nao-fazem-quarentena-e-avancam-sobre-afloresta-e-povos-indigenas-entrevista-especial-com-dom-roque-paloschi. Entrevista concedida em 06/5/2020. Acesso: 20 de maio 2020.
} 
A retórica que fomenta o preconceito e a discriminação, somada às políticas em curso do atual governo, é de desrespeito e de desconstituição da Constituição Federal. O resultado dessa política nefasta é a abertura e entrega do território para o capital econômico internacional, sobretudo com a Medida Provisória 910/19, que o governo enviou ao Congresso Nacional. Esta medida permite e legaliza a grilagem de terras, o desmatamento e os empreendimentos econômicos e, consequentemente, a invasão e devastação das Terras Indígenas e dos territórios tradicionais.

Ademais, acrescenta Paloschi:

O atual governo, além dos inúmeros decretos, medidas provisórias, vem dissecando economicamente e inviabilizando politicamente o trabalho dos órgãos de fiscalização e proteção das Terras Indígenas e as políticas públicas no campo da educação, saúde e sustentabilidade, sem falar na paralisação de todas as demarcações de terra. A partir desse cenário, no Brasil, vai se firmando a postura autoritária de um governo que segue as orientações do capital econômico, em detrimento da nossa Lei Magna, a Constituição Federal. [...] Desde que assumiu a presidência, Bolsonaro deixou clara sua política de trabalho: abrir as Terras Indígenas brasileiras para a exploração do subsolo e dos recursos hídricos com o falso discurso de que elas devem ser aproveitadas economicamente, apresentando o PL 191/2020. O PL 191/2020, somado à retórica do governo brasileiro, aumentou o número de garimpos ilegais em Terras Indígenas, agravando ainda mais as invasões dessas terras, sobretudo na região amazônica, onde se concentra um grande número de riquezas minerais. O PL 191/2020 se configura como um projeto de morte para os povos indígenas e, consequentemente, a invasão e a desterritorialização dos povos indígenas, assim como a violação dos direitos e perda da autonomia, duramente conquistados e garantidos na Constituição brasileira e em tratados internacionais.

Além disso, Dom Roque Paloschi aborda a concepção de "superioridade" trazida pelos portugueses e diz:

O grande problema é a visão de superioridade da cultura ocidental em relação aos demais povos e crer que os povos indígenas são empecilhos para o desenvolvimento econômico do país. Desde 1500 até hoje, temos uma cultura que não quer ver a diversidade e a diferença cultural como potencialidade e possibilidade de um novo projeto de vida, novo paradigma civilizatório. Os povos indígenas, com seus projetos próprios de vida, nos apresentam uma nova forma de relação com a casa comum e com todos os seres criados. Tudo está interconectado, 'tudo o que fizermos à terra, faremos aos filhos da terra'. Este grande aprendizado nos livraria dos caos, da morte e da destruição.

A visão eurocêntrica de "superioridade" trazida pelos imigrantes europeus chamados de "conquistadores" trouxe como consequência a falta de respeito à cultura dos habitantes nas terras Brasis. Essa visão permanece inserida na cultura do povo brasileiro de que os indígenas são preguiçosos e dessa forma, são empecilhos para o desenvolvimento econômico do Brasil. 


\title{
3.5 REGULARIZAÇÃO FUNDIÁRIA
}

Maria Petronila Neto, ao se manifestar sobre Plano de Desenvolvimento Sustentável para Rondônia (PDES), destaca:

\begin{abstract}
É bem curioso esse Plano de Desenvolvimento Sustentável para Rondônia (PDES-RO), porque a experiência que temos por acompanhar as questões agrárias em Rondônia, referente à questão das políticas de regularização fundiária dos pequenos agricultores no estado, bem como dos territórios dos povos tradicionais e aí se inclui as comunidades quilombolas, além dos povos originários, ou seja, os indígenas; observamos que nem o governo estadual e nem o governo federal tem política para demarcar e homologar os territórios indígenas e nem de regularização das terras dos pequenos agricultores. Nessa perspectiva é que fica difícil admitir a existência de um projeto de desenvolvimento sustentável para o estado.

O que observamos é que prevalece em Rondônia a política de apoio ao agronegócio. Nesse sentido é que entendemos não ser possível conciliar o agronegócio com a agricultura familiar.

Em Rondônia existem 54 povos indígenas e apenas 20 terras são demarcadas, e dessas 20 terras indígenas eu acredito que 100\% delas estão com problemas de invasões, seja por questões de mineração e/ou questão de madeireira.
\end{abstract}

Observa-se na fala de Maria Petronila Neto que o governo federal, através do Instituto Nacional de Colonização e Reforma Agrária (INCRA), não tem política de regularização fundiária em Rondônia:

Aqui em Rondônia existe um número muito grande de terras públicas, que precisam ser regularizadas. O INCRA na década de 1980 distribuía grandes áreas de terras públicas através de contratos de alienação; as pessoas que recebiam essas terras tinham um prazo de 10 anos para desenvolverem uma determinada cultura que na maioria das vezes eram destinadas ao plantio de café ou cacau. Por outro lado, ao invés de plantarem essas lavouras, faziam pastos e colocavam bois, e dessa forma quebravam automaticamente as cláusulas resolutivas do contrato, não podendo dessa forma, receberem os títulos dessas terras. Os movimentos sociais do campo, a partir da década de 2000, com essas informações de que essas terras estavam irregulares, passaram ocupar essas áreas, muitas dessas áreas estavam sendo abandonadas. Porém, o camarada ainda achava que tinha direito a terra, no entanto, as cláusulas do contrato haviam sido quebradas, ele havia perdido o direito. Esse suposto proprietário ingressava com uma ação judicial junto à justiça de Rondônia e ganhava uma liminar de despejo contras os trabalhadores. Dessa forma é que entendemos serem um dos maiores gargalos que a CPT acompanha hoje.

As áreas de maiores conflitos agrários hoje, estão localizadas no Cone Sul do estado, e em sua maioria estão relacionadas ao Contrato de Alienação em Terras Públicas (CATP) (Sic). 


\section{Maria Pretronila Neta acrescenta:}

Os Estados do Pará e de Rondônia são os dois estados que por 2 (dois) anos (2015 e 2016), consecutivos, que têm acumulados os maiores índice de assassinatos no campo, por conflitos agrários no Brasil. Esses conflitos decorrem do método do latifúndio que além de deterem a força jurídica através do judiciário, utilizam a pressão direta com a pistolagem. Nos anos de 2015, 2016 e 2017, Rondônia teve um índice altíssimo de assassinato no campo: 20 trabalhadores em 2015, 21 em 2016, e 17 em 2017, inclusive com denúncias de envolvimentos de agentes do estado em pistolagem, como foi caso ocorrido na fazenda Tucumã, no município de Cujubim, em que 2 (dois) trabalhadores rurais foram assassinados e que contou com envolvimento comprovado de um policial militar. Esse policial juntamente com o fazendeiro foi condenado à prisão. Foi um dos únicos casos aqui em Rondônia que o crime foi desvendado (Sic).

A interlocutora analisa os conflitos agrários no campo em Rondônia destacando que as causas estão relacionadas à disputa pelas terras públicas de trabalhadores já assentados, bem como de trabalhadores acampados, buscando terra para trabalharem. E destaca: "Nesse sentido, se verifica que o estado faz vista grossa para esse tipo de conflito, que em muitos casos seria fácil de resolver se o estado tivesse um compromisso com o desenvolvimento sustentável”.

Em complementação, Marcelo Thomé traz para a discussão a regularização fundiária das terras públicas ocupadas, tanto rurais quanto urbanas, na Amazônia, e por conseguinte no estado de Rondônia, como sendo uma necessidade prioritária, proporcionando a construção de uma agenda que garanta o processo de desenvolvimento sustentável, assim diz:

Na agenda de bioeconomia de crédito de carbono, de manejo sustentável a regularização fundiária é determinante. Essa agenda no nosso entendimento é prioritária para Rondônia e também para toda a Amazônia. No campo político se precisa vencer esse passivo de regularização fundiária, rural e urbano. Isso é um ponto determinante para avançar no processo sustentável de desenvolvimento econômico do Estado. Precisa ter um ambiente regulatório que permita mecanismos ágeis de concessão de florestas, de mineração, de atividade econômica nas áreas de conservação. Porque não haverá conservação com isolamento, que é o que a gente tem experimentado em grande medida no Brasil. O modelo de conservação vigente hoje, em que isola a área, não garante a conservação daquele território. Por diversos fatores, um deles é que o Estado não tem capacidade financeira, humana, tecnológica pra garantir a integridade de todas essas Unidades de Conservações espalhadas pelo Brasil.

As florestas nacionais concedidas a manejo sustentável são conservadas, porque o concessionário é obrigado a conservar, cuidar, proteger e manter. Percebe que a mudança no ambiente regulatório e até o olhar sobre como é que a gente preserva, pode gerar, não só mais preservação como desenvolvimento econômico. E aí que, a gente tem que sentar para conversar e fazer escolhas, novas escolhas, para novos caminhos. 
O interlocutor destaca que a temática do desenvolvimento sustentável deve ser vista como oportunidade para o investimento na região, porém sendo de responsabilidade do Estado as ações das políticas públicas de regulação que visem à agilidade de investimento em novos setores da economia, "para que possa produzir satisfação para população que aqui reside, visando atendimento das necessidades básicas como: saúde, educação, enfim de uma população da Amazônia que estão abandonadas" (MARCELO THOMÉ).

Para o Avenilson Gomes da Trindade, os motivos que têm levado à violência no campo são:

[...] os mais diversos, mas com certeza uma ampla regularização fundiária ajudaria muito a reduzir conflitos na região por causa de disputa de terras, há uma estimativa de que 90 mil das 146 mil propriedades rurais demanda por titulação definitiva, isso mostra o tamanho do desafio que precisa ser superado.

Observa-se que, para ele, a falta de regularização fundiária se constitui em um desafio para o governo, pois 90 mil propriedades das 146 demandam por titulação de terra em Rondônia. Com relação à migração interna, o ex-coordenador de desenvolvimento da SEAGRI, Avenilson, afirma:

A mobilidade de mão de obra agrícola é histórica no Brasil, Rondônia possui relação de proximidade com o Amazonas e o Acre, muitas vezes o acesso a terra e a busca por novos horizontes estimulam esse movimento, Rondônia muito embora tenha expansão significativa de monoculturas como soja e milho, ainda há $85 \%$ das 146 mil propriedades rurais com a agricultura familiar e muitas oportunidades e políticas públicas para acesso aos programas de fomento e apoio a produção.

Para o interlocutor, a migração se dá devido à proximidade dos estados do Acre e do Amazonas, e embora exista a expansão da monocultura do agronegócio, a permanência de pequenos agricultores no campo em Rondônia é de $85 \%$ ou 146 mil pequenas propriedades rurais. Não aborda, por outro lado, a pressão que o agronegócio vem fazendo aos pequenos e médios agricultores, embora admita a existência de disputa pela posse da terra. 


\subsection{ODR E O ESPAÇO DE MEDIAÇÃO NA PERSPECTIVA DOS ATORES}

\section{Figura 19 - Portal do Observatório de Desenvolvimento Regional (ODR)}

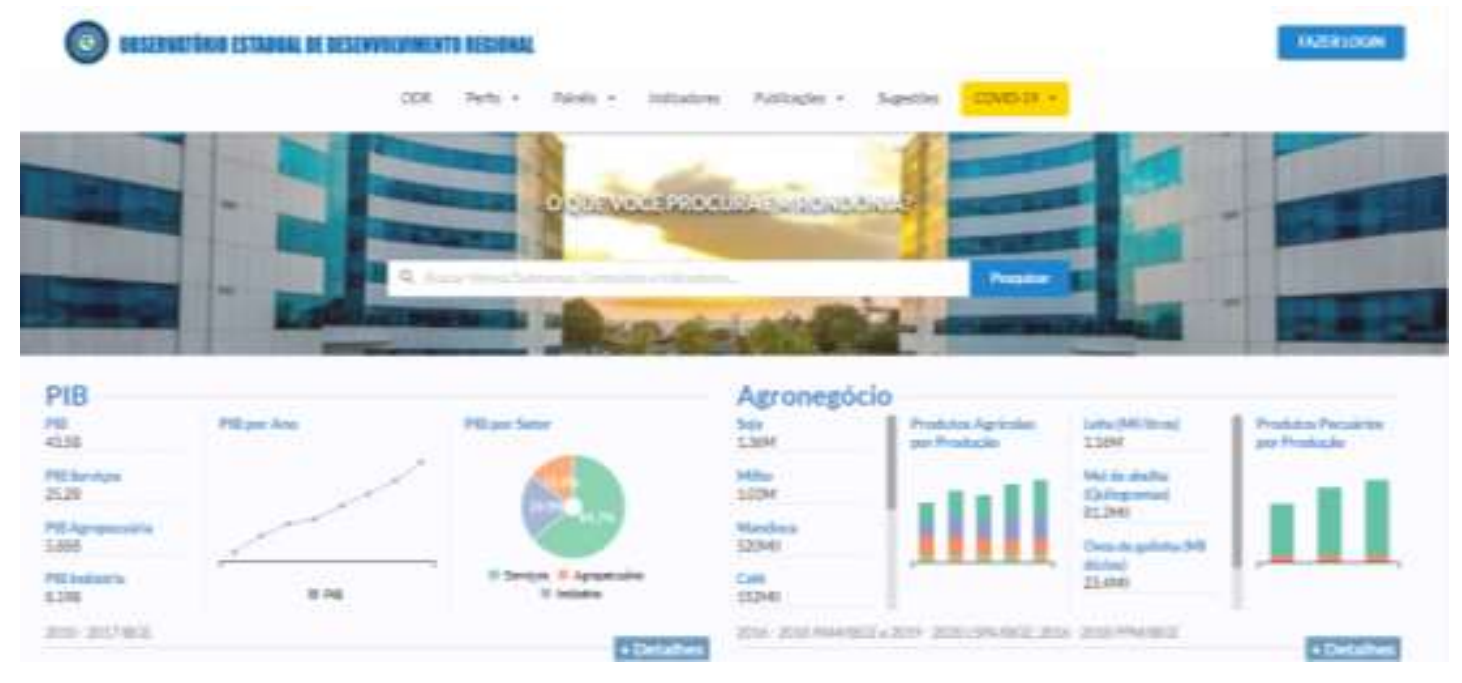

Fonte: Gov. Rondônia (ODR) - 2020

Em 30/10/2017 foi publicada a matéria no site da Secretaria de Estado do Planejamento Orçamento e Gestão (SEPOG) intitulada "Implantação da ferramenta Observatório Estadual avança em Rondônia"26. A matéria anunciava o lançamento da plataforma como um instrumento de armazenamento de informação e mediação, deixando claro o objetivo do Observatório do Desenvolvimento Regional de Rondônia (ODR): “[...] agilizar a implantação da ferramenta online 'Observatório do Desenvolvimento Estadual', onde mais de um milhão de informações estarão disponíveis”. E expõe:

O projeto foi idealizado a partir da institucionalização da Política Estadual de Desenvolvimento Regional (PEDR) com o objetivo de melhor monitorar e avaliar os planos, programas e ações desta política por meio do intercâmbio de informações com os demais órgãos, entidades da administração indireta, organizações da sociedade civil, municípios, entre outros.

A matéria ainda acrescenta a fala do secretário da SEPOG à época, George Braga, destacando:

Também será possível que o cidadão utilize os indicadores para realização de pesquisas respondendo questões como, por exemplo, a quantidade de

\footnotetext{
${ }^{26}$ Cf. "Implantação da ferramenta Observatório Estadual avança em Rondônia". Disponível em: http://sepog.ro.gov.br/Noticia/Exibir/1043?titulo=Implanta\%C3\%A7\%C3\%A3o\%20da\%20ferramenta\%20Obse rvat\%C3\%B3rio\%20Estadual\%20avan\%C3\%A7a\%20em\%20Rond\%C3\%B4nia\&nome=GDPP. Acessado em: 19.10.2020.
} 
municípios/estados de faixa de fronteira; a renda per capita por município/estado em determinado ano; o valor disponibilizado para municípios/estado em determinado ano. 'As informações também podem direcionar atos de gestão servindo como base na tomada de decisões’ [...].

Observa-se que o ODR se constituiu em um instrumento de armazenamento de informações e ao mesmo tempo coloca os dados a disposição para o atendimento da sociedade a partir dos municípios. Porém para o atual governo (2020) a política de mediação do governo com a sociedade não vem se ocorrendo no Observatório de Desenvolvimento Regional (ODR), como se manifesta o secretário da SEPOG:
A mediação não acontece propriamente dentro do Observatório Estadual de Desenvolvimento Regional (ODR). O observatório consolida as informações, alimenta o sistema para atender a essa demanda da classe empresarial que queira saber sobre as potencialidades do nosso estado e quais são os incentivos fiscais. Então isso faz parte das informações contidas no observatório. Mas a questão da mediação acontece na verdade quando se realiza o Plano Plurianual (PPA), em que se realizam audiências públicas nos 52 municípios através dos 10 polos regionais. Nesses eventos, se escuta a sociedade civil organizada e toda a população - seus anseios e as suas necessidades -, nesse momento os políticos também se fazem presentes e apresentam as suas demandas e nós colhemos as informações para serem consolidadas no PPA. É através do PPA que se estabelece a consolidação das prioridades, casado com o Plano de Desenvolvimento Estadual Sustentável (PDES) que é o programa de estado que se projetou para ser implantado de 2015 a 2030, enquanto que o PPA é o plano de governo que se estabelece para 4 (quatro) anos. Essas informações passam ser alimentadas no observatório e disponibilizadas para a sociedade (PEDRO PIMENTEL).

Aqui verifica-se que o governo promove diálogo com a sociedade tanto política, quanto com a sociedade civil, apenas por ocasião da elaboração do Plano Plurianual (PPA) que envolve todos os municípios nas 10 (dez) regiões. Deixa claro o secretário da SEPOG que o ODR funciona apenas como dispositivo de informações, porém quando se tem acesso ao site ODR, percebe-se que o mesmo, além de não reunir as informações do governo, não se encontra atualizado e dessa forma não permite que a sociedade possa ter acesso às informações. Por outro lado, o gerente do Observatório, Jorge Ugaldi ${ }^{27}$ ao se manifestar sobre o processo de mediação envolvendo o ODR, informa:

A dificuldade que encontramos é que as secretarias do governo não vêm disponibilizando as informações para que se possa trabalhá-las e disponibilizá-las no ODR. Essa é uma questão cultural que aos poucos esperamos que seja vencida.

Já realizamos reunião com a participação do secretário da SEPOG e vários secretários para mostrar que o Observatório não é da SEPOG, mas uma

\footnotetext{
27 Jorge Ugalde - Gerente do Observatório (GOB-SEPOG), entrevista concedida em fevereiro de 2020.
} 
plataforma de informação do governo do estado de Rondônia e que está disposto no PDES-RO. As informações disponibilizadas pelas secretarias, quando chegam para nós, se tornam públicas através do ODR. É lógico que às vezes existem informações que são restritas que não se pode colocar à disposição.

As informações ajudam a subsidiar as tomadas de decisões tanto em nível de governo, quanto da classe empresarial, em suas aspirações como investidores no estado, bem como da sociedade civil e da comunidade científica. A resistência existe, mas isso tá sendo quebrado gradativamente em função de quando se mostra a importância de se disponibilizar as suas informações.

Como se pode observar na fala de Ugaldi, o ODR não está armazenando informações devido à falta de cultura das secretarias de estados em fornecer os dados para serem publicados, ou seja, não está funcionando conforme previsto no PDES-RO, o que demonstra a falta de políticas para o acesso à informação e mediação.

Já para o ex-coordenador de Desenvolvimento Agropecuário da SEAGRI, Avenilson Gomes da Trindade:

O ODR tem um papel fundamental para avaliação da efetividade da política pública em Rondônia a partir dos dados publicados, porém, está em processo de consolidação e a tendência é aumentar sua base de dados e acesso às informações. A cultura de organizar e articular os dados para tomada de decisão também é um processo que tem crescido isso fará do ODR uma grande plataforma para a sociedade rondoniense.

A percepção de Avenilson Trindade coincide com a do coordenador do ODR, ou seja, de que não existe uma cultura estabelecida pelo corpo governamental a fim de que o Observatório possa servir como uma plataforma de informação e dar suporte para o governo em suas tomadas de decisão. Também pode se deduzir que sem as informações disponíveis de forma unificada, há dificuldade no acesso e na mobilização da sociedade civil para intervenção nas políticas públicas.

Com relação participação da sociedade civil nas ações do governo, Pedro Pimentel, esclarece:

Embora esteja previsto no PDES-RO, a discussão com a sociedade sobre a implantação de programas e projetos que atendam as diretrizes do PDESRO, isto não vem acontecendo de forma efetiva em virtude de que não foi implantada a Governança do PDES-RO tal qual está previsto no mesmo.

Como se observa, o governo ainda não implantou um sistema de governança previsto no PDES-RO, ou seja, o Conselho Estadual de Desenvolvimento. Segundo Pedro Pimentel, esse Conselho seria um espaço de negociação e de tomada de decisão; nele, se aglutinariam representações da sociedade civil, tanto da classe empresarial, quanto de trabalhadores. Por 
outro lado, denota-se a falta de políticas públicas para que a sociedade possa participar das ações do governo com vista à construção de uma sociedade democrática.

Ademais, Marcelo Thomé (FIERO) ao abordar sobre a relação da sociedade civil com o estado, nessa gestão (2019-2023) diz:

Não há como imaginar um governo isolado da sociedade civil organizada. E da mesma forma, não há como a sociedade civil organizada prescindir das políticas públicas do governo como regulamentador, e orientador muitas vezes do próprio processo de desenvolvimento. A oportunidade econômica é percebida pelo empresário, mas se não tiver um ambiente favorável para que ele empreenda isso não vai virar realidade.

É fundamental equilíbrio entre a percepção da oportunidade e o estabelecimento da política pública para que isso ganhe força, ganhe musculatura e se torne realidade. Faz-se necessário dialogar permanentemente como o governo para se enfrentar o ambiente tributário, ambiente da educação, da infraestrutura, no ambiente regulatório, a questão de licenciamento, são questões inerentes ao poder do Estado. Se isso aqui é hostil ao empreendedor, não avança a agenda do desenvolvimento. O que percebemos é que neste governo essa situação está paralisada, o que existe é um dispositivo de informação chamado Observatório de Desenvolvimento Regional onde não estão contidas todas as informações necessárias para um diálogo com a sociedade como um todo com o governo.

Para Marcelo Thomé, o atual governo não vem dialogando com os entes da sociedade civil, o que dificulta na construção de um marco regulatório que possa disciplinar, através de políticas públicas, as ações da iniciativa privada e impulsionar para o desenvolvimento sustentável. Da mesma forma, observa-se que embora o governo, através do PDES-RO, tenha criado o Observatório de Desenvolvimento Regional (ODR), o mesmo não foi de fato implantado com a sua finalidade, visto que se configura como um dispositivo, mas sem concentrar as informações necessárias para promover o diálogo com a sociedade civil.

Já Maria Petronila Neto, sobre os espaços de diálogo da sociedade com o governo, principalmente relacionado aos conflitos no campo e a necessidade pela regularização fundiária, explica:

Houve um único espaço de diálogo no governo anterior, do Confúcio Moura em 2016, em que foi criada uma mesa de diálogo para discutir a questão dos conflitos agrários no estado, ali dava para discutir. As reuniões aconteceram 2 (duas) vezes no ano. Nesse período foi o auge da violência no campo no estado. Houve algumas intervenções que foram possíveis, a partir da mesa de diálogo, como por exemplo, o caso que ocorreu na fazenda Bom Futuro, localizado no município de Seringueiras, em que os trabalhadores rurais sem terras, sentaram para dialogar com o governo. Naquele momento, foi possível dialogar e estabelecer encaminhamentos para amenizar a situação e evitar um derramamento de sangue naquela região. Algumas providências interessantes foram possíveis de se realizar no governo passado. No atual governo do Cel. Marcos Rocha, até o momento não fomos chamados para novas mesas de diálogo. 
De acordo com a líder da CPT, o atual governo não criou um espaço de mediação para dialogar com os movimentos sociais do campo, principalmente no que se refere à violência no campo. Já para o líder do MST-RO, Claudinei (Tijolão), os governos criam métodos para mediar os conflitos na sociedade, contudo ficam apenas na teoria e não alcançam as necessidades reais do povo e complementa:

Não funcionam, porque os planos de ação são criados em gabinetes e consequentemente a correia transmissora que serviria como elo entre o governo e a sociedade civil, é composto na sua maioria por técnicos burocráticos. Veja por exemplo como são compostos os chamados conselhos participativos. Geralmente de 15 cadeiras, 12 ou 13 são de representantes de governos, e 2 ou 3 da sociedade civil.

Como pode se observar nas falas dos interlocutores, o governo de Rondônia não efetivou instrumento de mediação para dialogar com a sociedade, já que a participação da sociedade civil nos Conselhos é pequena, ou seja, as decisões são tomadas por representação na sociedade política. Contudo para ex-governador Daniel Pereira, existe uma dificuldade de se discutir com a sociedade civil visto que não se encontra organizada e assim diz:

A partir do momento em que a FIERO a FAPERON e a FECOMERCIO se organizaram melhorou a relação com o governo e passaram a ter mais harmonia governativa dentro das suas instituições, passaram a manter uma presença mais ativa, mais participativa, em conjunto com outras instituições no estado de Rondônia. Nesse sentido, todas as ações que o governo fez, foram ações do governo juntamente com a sociedade civil, hora o governo puxando a sociedade civil e ora a sociedade civil puxando o governo, mas um ajudando o outro.

Por outro lado, Lazinho da FETAGRO ao falar sobre o ODR criado pelo governo e contido no PDES-RO para servir como dispositivo de armazenamento de informações e ao mesmo tempo como mediação do governo com a sociedade como um todo, é enfático: "Esse governo nem sabe o que é PDES-RO, infelizmente", deixando claro em sua manifestação que não existe canal de diálogo do governo com a sociedade civil.

\subsection{A ODR COMO INSTÂNCIA DE MEDIAÇÕES}

Silveira, Felippi e Campos (2013, p. 12) ao analisarem sobre as mudanças decorrentes do processo das novas tecnologias da informação e do conhecimento destacam que a regionalização se insere no processo da globalização.

Cada vez mais, o lugar e a região redefinem-se com base no potencial integrativo do novo padrão tecnológico, adquirindo densidade técnica, informacional e comunicacional em função do acesso e da sua posição em relação às redes informacionais que se estabelecem em escala planetária. 
Os autores acrescentam:

O acesso das populações às tecnologias de comunicação e de informação (TICs) é também sem precedentes, o que, por um lado, tem sido estimulado e viabilizado pelo mercado. Porém, por outro, acaba permitindo novas formas inclusive de contestação do próprio sistema, como ciberativismo, por exemplo. Ou seja, as revoluções tecnológicas da virada do final do século XX têm ampliado as possibilidades de democratização das TICs, seja no acesso, bem como na produção de conteúdo, viabilizando contato com informações, culturas e mentalidades de públicos antes alijados deste processo, incluindo neste acesso as possibilidades de interatividade. Esta via permite que se venha rompendo com o sentido tradicional da relação entre produtores dos meios de comunicação e de informação e usuários (representada pelo esquema: emissor $\rightarrow$ receptor), passando para uma relação de duplo fluxo (emissor $\leftrightarrow$ receptor). (SILVEIRA; FELIPPI; CAMPOS, 2013, p.23)

Como já observado, essa sociedade de informação vem redimensionando as relações socioculturais e econômicas em decorrência das novas TICs. Esse processo aproxima cada vez mais o regional do global, ou seja, desterritorializando o local. Contudo não se pode pensar o global para o regional, mas sim o inverso: pensar o global a partir do regional. Além disso, é importante lembrar que sempre houve mudanças nas sociedades, contudo o que se vive no presente milênio é um acelerado processo de transformações, sendo necessário entender que cada povo tem o seu aprendizado histórico, o que materializa a sua cultura.

Thiry-Cherques (2006, p. 35) ao trabalhar o conceito de campo tendo como referencial Bourdieu enfatiza-o com sendo um espaço de relações objetivas e de conflitos, e diz: “O campo é tanto um 'campo de forças', uma estrutura que constrange os agentes nele envolvidos, quanto um 'campo de lutas', em que os agentes atuam conforme suas posições relativas no campo de forças, conservando ou transformando a sua estrutura”. Nessa concepção de correção de força que se estabelece na sociedade, o autor acrescenta:

A estrutura do campo é dada pelas relações de força entre os agentes (indivíduos e grupos) e as instituições que lutam pela hegemonia no interior do campo, isto é, o monopólio da autoridade que outorga o poder de ditar as regras, de repartir o capital específico de cada campo. A forma como o capital é repartido dispõe as relações internas ao campo, isto é, dá a sua estrutura. (THIRY-CHERQUES, 2006, p. 37).

A concepção de campo deve ser pensada como um espaço simbólico onde os agentes da sociedade se agrupam, criam e legitimam as próprias regras. Os diferentes campos estão em disputas, da mesma forma que as classes estão em disputas. O capital pode ser compreendido como um campo, mas também como classe e por essa razão de querer reproduzir o capital requer a hegemonia. Nesse sentido é que pode tratar o campo como sendo um espaço antagônico em que se estabelece a disputa pela hegemonia. 
Marteleto e Silva (2004, p.45) tratam do capital social como uma concepção que estabelece a disputa pela hegemonia entre as classes sociais antagônicas, ou seja, entre a classe dominante e a classe subalterna. Assim explicam: "Existem evidências de que o capital social pode ser usado para promover a redução da pobreza, o desenvolvimento e o bem-estar social, o que aproximaria os interesses da sociologia e da economia nesse campo". E acrescentam:

O capital social gera externalidades, mas sua análise deve transcender esse ponto, isto é, o capital social entendido como um conjunto de redes e normas, permitindo a redução dos riscos decorrentes das relações entre desconhecidos e, consequentemente, dos custos de transação. No entanto, sua mensuração é problemática e, embora ele possa ser associado ao desenvolvimento, especialmente local, sua promoção não é trivial, ou seja, como ele está incrustado nas redes de relações sociais, não é evidente, do ponto de vista das pesquisas na área de economia, como a sua expansão ou modificação pode afetar o bem-estar de seus componentes. (MARTELETO e SILVA, 2004, p.45).

$\mathrm{Na}$ organização das sociedades atuais, visando as disputas nos campos, deve-se levar em conta o uso das novas TICs. O uso das TICs é importante, porque quem as detém as usam de forma hegemônica e podem construir a narrativa. Ou seja, o resultado é uma narrativa hegemônica que se combina com a perspectiva de luta de classes. Nesse contexto, as redes sociais se estabelecem como novas ferramentas de organização da sociedade civil. Marteleto e Silva (2004, p. 46) observam que:

Muitas redes se iniciam a partir da tomada de consciência sobre algum problema vivenciado por uma ou mais comunidades, ou a partir de situações de mobilização mais amplas. Criam-se, nas redes, formas institucionais próprias associadas aos direitos, responsabilidades e tomadas de decisão. A posição de cada indivíduo na rede depende do capital social e informacional que consiga agregar para si próprio e para o conjunto. A margem de decisão de um indivíduo inserido em uma rede social está sujeita à distribuição de poder, à estrutura de interdependência e de tensões no interior do grupo. É a ocupação de determinadas posições na rede da comunidade, de especial acesso a informações, que determina o sucesso das ações dos indivíduos e seus grupos.

Nesse sentido pode se afirmar que uma sociedade democrática requer a transparência dos acontecimentos nos governos, e dessa forma a apropriação da informação passa ser um direito. Nessa perspectiva, a sociedade civil passa empregar as redes sociais como ferramentas estratégicas no contexto da disputa do campo. Assim, os Observatórios de Desenvolvimento Regional (ODR) deveriam servir como dispositivos de informação oficial. A partir da posse das informações contidas nos mesmos, seria possível a sociedade civil constituir-se como interlocutora dos governos, construindo espaços de mediação, objetivando a construção de políticas públicas para superação dos problemas regionais. 
Marteleto e Silva (2004, p.46) afirmam: "Evidencia-se, por outro lado, que os indivíduos organizam suas ações nos espaços políticos em função de socializações e mobilizações suscitados pelo próprio desenvolvimento de suas redes”. E, ainda: “As relações com outras esferas, além do espaço comunitário, são influenciadas pela existência das redes sociais, que operam como mediadoras entre a sociedade e o Estado". As ações decorrentes dessa nova forma proporcionam abordagens sociais a partir do poder local.

Além disso, Bobbio (1997, p.60), ao analisar sobre a função das instituições públicas destaca:

\begin{abstract}
A função das instituições políticas é a de dar respostas às demandas provenientes do ambiente social ou, segundo uma terminologia corrente, de converter as demandas em respostas. As respostas das instituições políticas são dadas sob a forma de decisões coletivas vinculatórias para toda sociedade. Por sua vez, estas respostas retroagem sobre a transformação do ambiente social, do qual, em sequencia ao modo como são dadas as respostas, nascem novas demandas, num processo de mudanças contínua que pode ser gradual quando existe correspondência entre demandas e respostas, brusco quando por uma sobrecarga das demandas sobre as respostas interrompe-se o fluxo de retroação e as instituições políticas vigentes, não conseguindo mais dar respostas satisfatórias, sofrem um processo de transformação que pode chegar à fase final da completa modificação.
\end{abstract}

Dessa forma, para que o Estado enquanto sociedade política adote posicionamento em favor da sociedade civil, faz-se necessário a existência de uma correção de força permanente no campo da disputa hegemônica, em favor da classe subalterna.

A sociedade atual, ou sociedade da informação, em uma abordagem de Melucci (2001) entende que o poder também desempenha um papel simbólico nas sociedades baseadas na informação. Nesse sentido, determinados multiplicadores simbólicos tornam imprevisíveis os efeitos da comunicação. É também importante descontruir a suposta "neutralidade técnica" de instâncias como a ODR e a construção de discursos que muitas vezes procuram ocultar ou deslegitimar certas posições:

Pode-se, enfim, favorecer, respeitar e promover aquela parte do discurso público que se forma nas redes cotidianas, nas solidariedades submersas, nas escolhas de consumo dos cidadãos. A consciência da natureza construída pelo discurso público, da sua inevitável 'parcialidade', não pode nos obrigar a subestimar nenhum desses planos, nem o peso relativo que cada um deles exerce, esporadicamente, na formação, circulação e assimilação das informações. (MELUCCI, 2001, p. 146)

No contexto de uma sociedade da informação e tendo em vista o contexto do desenvolvimento regional, o ODR se constitui em um instrumento referencial para aglutinar informações que sirvam como instrumento de mediação entre governo e a sociedade civil. 
Martins, Vaz e Caldas (2010) quando tratam sobre desenvolvimento local, mesmo destacando que o assunto seja controverso, enfatizam a cidadania como instrumento fundamental para a atuação da sociedade civil no que diz respeito à disputa do campo e que possibilitará o avanço da democracia e, dessa forma, os governantes são obrigados a implantarem políticas públicas em atendimento às necessidades da população, principalmente as menos assistidas.

Outro ponto que merece destaque diz respeito existência de conflitos nas terras indígenas em Rondônia, neste momento estimulado pelas falas do presidente da República, bem como pela falta de políticas públicas voltadas à preservação ambiental e o respeito às culturas indígenas. Desenvolvimento e governança são temas recorrentes na abordagem de se implantar políticas públicas com vista ao regional. Athias (2007, p.24) retoma a discussão sobre as concepções de desenvolvimento:

Nesses espaços, têm sido discutidas as teorias sobre identidade étnica que dão sustentação aos princípios do etnodesenvolvimento, colocando-se como uma crítica às teorias de desenvolvimento hegemônicas praticadas pela maioria dos países da América Latina. O etnodesenvolvimento se coloca como uma possibilidade de desenvolvimento econômico, proporcionando o aumento da qualidade de vida e o fortalecimento das identidades étnicas das populações indígenas.

O autor acrescenta:

A política indigenista oficial aplicada depois da criação do SPI em 1910, nunca enfocou de fato a diversidade cultural dos índios do Brasil. $\mathrm{O}$ índio sempre foi considerado uma categoria genérica devendo ser integrado à sociedade nacional. E o próprio órgão oficial colabora na difusão desta imagem do índio genérico. Tal integração pressupõe, desde o começo, que uma só política de aproximação e atração é utilizada para todos os grupos indígenas em qualquer grau de contato com a sociedade nacional. Esta política indigenista na sua prática confirma a "redução" das etnias indígenas a uma só categoria abstrata chamada: índio, inventada pelo "civilizado" outra categoria abstrata. (ATHIAS, 2007, p.31).

Por outro lado, se percebe a discussão pelo governo federal, em nível nacional, sobre a extração de minérios nas terras indígenas. Nesse contexto, Athias (2007) analisa que houve avanços na política indigenista garantidos na Constituição Federal de 1988.

Com relação às terras indígenas a Constituição reconhece não apenas a ocupação física das áreas habitadas pelos índios, mas sim a ocupação de acordo as tradições culturais. Neste sentido, o Artigo 20 amplia o conceito de território indígena a toda extensão de terra necessária à manutenção e preservação das tradições imemoriais e culturais dos povos indígenas. $\mathrm{O}$ Artigo 22 mantém a competência do Estado para legislar sobre as populações indígenas e reconhece assim o direito dos índios de preservar sua identidade étnica e suas formas de organização abandonando assim o caráter de transitoriedade da condição de indígena que cessaria com a chamada (ATHIAS, 2007, p.32). 
Modelos de desenvolvimento e políticas públicas indigenistas são temas que necessitam permanentemente serem tratados em um espaço de mediação entre governos e lideranças das etnias indígenas, bem como das representações da sociedade civil que apoiam as causas indígenas. Nessa perspectiva, o ODR deveria se constituir nesse espaço de diálogo.

Almeida e Damian (2015, p.4), ao abordarem sobre o papel das novas Tecnologias da Informação e do Conhecimento (TICs) em um campo de conhecimentos denominado "Humanidades Digitais", analisam que houve um crescimento exponencial, tanto por parte dos indivíduos e/ou grupos quanto por parte de governos. E acrescentam:

Nesse processo são geradas novas formas de solidariedade, de identidade, de ação social, assim como novas fontes de recursos econômicos. A complexa configuração contemporânea desse sistema tecnocultural acaba gerando a necessidade de um sofisticado aparato de informação, que envolve recursos (físicos e humanos) cada vez mais amplos.

Os autores destacam a necessidade de aprimorar novas formas de mediação, visto que se faz necessária a ampliação tanto do acesso quanto da circulação da informação; contudo, como a informação se constitui como uma moeda de valor nas TICs, o capital econômico se apropria para reproduzir e acumular valor. Por outro lado, é imprescindível capacitar a população nas áreas política e tecnológica a fim de que possam incorporar essas possibilidades no cotidiano. Dessa forma Almeida e Damian (2015, p. 6) vão dizer:

Em outras palavras: a preocupação, de um lado, de fazer circular a informação e torná-la pública, especialmente a informação cultural e, de outro, a preocupação em capacitar e formar os atores envolvidos (individuais e coletivos). A constituição de um novo campo de conhecimento e reflexão interdisciplinar que congregaria muitas destas inquietações, o das chamadas 'Humanidades Digitais', chamou-nos a atenção nesse sentido. Este campo abre algumas perspectivas que nos são caras, como as discussões acerca da apropriação da informação, dos aspectos de empoderamento (empowerment) presentes nas ações e políticas culturais, traduzíveis em iniciativas e experimentos voltados à construção e criação de competências e habilidades no uso dos recursos proporcionados pelas TICs.

Nesse ponto, chama a atenção para o apontamento dos autores de se ampliar as formas de comunicação através do uso das novas TICs. Nesse sentido, entende-se o Observatório de Desenvolvimento Regional (ODR) como um dispositivo de informação e comunicação, sendo um mecanismo que possibilite a mediação entre o governo e a sociedade civil como todo, com vistas a debater os problemas socioeconômicos para encontrar soluções e se estabelecer políticas públicas que atendam a sociedade. 


\section{CONSIDERAÇÕES FINAIS}

Mediação da informação e desenvolvimento regional sustentável em Rondônia são temas centrais abordados no presente trabalho. Para se compreender sobre mediação, foi necessária leitura sistemática de alguns autores da Ciência da Informação (CI), bem como leituras relativas às mudanças socioculturais e econômicas decorrentes das novas Tecnologias da Informação e Comunicação (TICs) no processo de globalização. Lévy (2016) vai destacar que a técnica na atualidade se constitui em um elemento fundamental no jogo da transformação do mundo humano por ele mesmo; essas transformações, não são menos importantes na esfera intelectual, o que obriga um debate das tecnologias como um dos temas filosóficos e políticos.

O que se percebe na atualidade é que as mudanças decorrentes das novas tecnologias não são oriundas de pesquisas individuais, mas de esforços de grupos de trabalhos. Nesse sentido, Lévy (2016, p.174) diz: “O espírito humano não é um centro organizador em torno do qual giram tecnologias intelectuais, como satélites a seu serviço. Em si, não é nada além de um agenciamento de satélites de todos os tamanhos e todo tipo de composições, desprovido de um sol central", e acrescenta:

A técnica em geral não é nem boa, nem má, nem neutra, nem necessária, nem invencível. É uma dimensão, recortada pela mente, de um devir coletivo heterogêneo e complexo na cidade do mundo. Quanto mais reconhecemos isto, mais nos aproximaremos do advento de uma tecnodemocracia (LÉVY, 2016, p.188).

Com relação ao uso das Tecnologias da Informação e do Conhecimento (TICs) levouse em conta, no presente trabalho, a posição política do governo e os dispositivos de armazenamento de informação. Nessa condição, analisou-se a existência de mecanismos de governança em Rondônia, não somente para o armazenamento de dados e de informações em dispositivo, também como instrumento de transparência pública e se as informações armazenadas são utilizadas como instrumentos para mediação e posteriormente servem como apoio para se elaborar políticas públicas na perspectiva do desenvolvimento regional sustentável, conforme estabelecido no Plano de Desenvolvimento Sustentável para o Estado de Rondônia (PDES-RO).

Sobre a concepção de desenvolvimento regional sustentável foi utilizado como referencial principal os textos de Ignacy Sachs, embora se tenha debruçado em outros autores que deram suporte para a compreensão dessa temática. Outro referencial seguido foi Pierre 
Bourdieu para se compreender a disputa pela hegemonia e pela legitimidade no campo político entre instâncias da sociedade civil e instâncias do governo.

Para compreender a concepção de desenvolvimento contida no Plano de Desenvolvimento Sustentável para o Estado de Rondônia (PDES-RO) foi necessário realizar uma rápida abordagem sobre o processo histórico de ocupação humana na Amazônia brasileira.

Nesse sentido, o Brasil a partir dos anos 1950 começou a alterar a sua estrutura econômica de modo acelerado sobre o processo de industrialização iniciado na década de 1930, impulsionado principalmente pela implantação da indústria automotiva. Com o golpe militar de 1964, implantou-se o programa "Integrar para não Entregar", abrindo-se, dessa forma, novas fronteiras.

Para compreender sobre o processo histórico de ocupação da Amazônia brasileira, foram considerados os ciclos econômicos, tais como: drogas do sertão, extrativismo da borracha, mineração, madeira e por último as commodities. Ademais, também deve ser levada em conta a implantação da Zona Franca de Manaus (ZFM) em 1967, como um polo industrial, comercial e agrícola.

Na década de 1970, foi criado o Plano de Integração Nacional (PIN) visando impulsionar o processo de deslocamento de grupos humanos, principalmente de nordestinos para o norte do Brasil. Nesse período, foi impulsionada a criação de rodovias, como a Perimetral Norte, a Transamazônica, as Rodovias: BR 174 - Manaus-AM - Boa Vista-RR; BR 163 - Santarém-PA - Cuiabá-MT. Também foram criadas a Superintendência do Desenvolvimento do Nordeste (SUDENE), a Superintendência do Desenvolvimento da Amazônia (SUDAM) e o Instituto de Colonização e Reforma Agrária (INCRA), a fim de possibilitar o assentamento dos migrantes nessa nova fronteira.

Também foi importante destacar que a ocupação na região do oeste do Brasil, onde hoje se compreende Rondônia, se deu a partir do final do século XVII, como demonstram Cunha e Moser (2010, p.125):

[...] remonta o período colonial, onde nos fins do século XVII se encontravam algumas missões jesuíticas e em princípios do século XVIII. [...] No século XVIII, a região recebeu uma leva de colonizadores em busca de suas jazias de ouro, surgindo daí os primeiros núcleos habitacionais.

Com a exploração da borracha no século XIX, registra-se uma grande migração para região norte, pelos rios, em busca do "ouro branco". Outro fator migratório e imigratório se deu a partir da construção da Estrada de Ferro Madeira Mamoré (E.F.M.M.), de 1907-1912. A intensificação migratória se deu a partir do final de 1960, sendo destacadas as décadas de 
1970 e 1980. Nesse período houve a maior migração interna no Brasil. Em 1981, foi transformado o Território Federal de Rondônia em Estado.

Na década de 1980, o governo brasileiro, com o apoio do Banco Mundial (BM), criou o Programa de Desenvolvimento Integrado do Noroeste do Brasil (POLONOROESTE), objetivando a criação de estrutura para o funcionamento do Estado, recém-criado. Além disso, proporcionou a pavimentação da BR 364 em 1984, ligando o Estado do Mato Grosso ao Estado do Acre, passando por Rondônia, e estimulou os primeiros assentamentos de colonos na região, criando os Núcleos Urbanos de Apoio Rural (NUARES).

Na década de 1990, o governo criou o Plano Agropecuário e Florestal de Rondônia (PLANAFLORO) como correções das políticas adotadas pelo POLONOROESTE. Nesse período, houve uma articulação da sociedade civil organizada através do Fórum das Organizações Não governamentais (ONGs), em que reunia representações tanto das populações originárias (indígenas) quanto das populações tradicionais (extrativistas, pescadores artesanais e quilombolas), além de movimentos sociais urbanos, bem como de instituições públicas locais. O trabalho resultou na Lei do Zoneamento Sócio-EconômicoEcológico do Estado de Rondônia (ZSEE-RO), tendo como base estudos georeferenciados, que garantiram a criação das Unidades de Conservação (UC) e das Reservas Indígenas (RI), e Rondônia passou a ser o primeiro estado da federação a ser zoneado.

Por outro lado, deve-se destacar que os organismos multilaterais, preocupados com o crescimento populacional do planeta e com desastres ambientais que vinham acontecendo passaram a estabelecer políticas que possam pensar em um desenvolvimento sustentável. Nesse contexto, foi realizada a Conferência das Nações Unidas sobre o Desenvolvimento e Meio Ambiente Humano, ocorrido 1972, em Estocolmo, na Suécia, que é considerado um marco histórico por reunir diversos países para discutir as questões ambientais do planeta.

Outra iniciativa histórica sobre o desenvolvimento sustentável aconteceu na cidade do Rio de Janeiro em 1992, com a Conferência das Nações Unidas sobre o Ambiente e Desenvolvimento ou a Cimeira da Terra, ou como ficou conhecida "Rio 92", em que se aprovou a Agenda 21, cujo principal objetivo foi o desenvolvimento sustentável, definindo a necessidade de um desenvolvimento que assegure a preservação do planeta para as futuras gerações.

Em 2012 foi realizada, na cidade do Rio de Janeiro, a Conferência das Nações Unidas sobre Desenvolvimento Sustentável, a "Rio+20", como homenagem a 20 anos da Conferência "Rio-92”. Na ocasião, foram ratificadas as deliberações da Conferência das Nações Unidas 
sobre Meio Ambiente e Desenvolvimento e definida uma agenda do desenvolvimento sustentável para as próximas décadas.

Nessa mesma toada, em 2015, foi realizado o encontro de Paris, ou a $21^{\text {a }}$ Conferência do Clima, ou "COP 21", cujo objetivo principal foi estabelecer um acordo internacional a fim de diminuir a emissão de gases de efeito estufa, para diminuição do aquecimento global. $\mathrm{O}$ Brasil figura como signatário a partir de 2016, enquanto os Estados Unidos se recusaram a assinar em 2017.

Na década de 2000, foi criada a Iniciativa a Integração da Infraestrutura Regional Sulamericana (IIRSA), um consórcio formado por 12 (doze) países da América do Sul, com o objetivo principal de criação de infraestrutura logística que possibilite a circulação de mercadoria e energia elétrica para região, a fim de atender a transformação de produtos primários.

Entre 2008 e 2016 foram construídas 02 (duas) grandes hidrelétricas do rio Madeira, sendo a UHE Santo Antônio e a UHE de Jirau, no município de Porto Velho com transmissão de alta tensão direto para a cidade de Araraquara/SP.

Recentemente no governo de Confúcio Moura/Daniel Pereira (2015-2019), o governo de Rondônia criou o Plano de Desenvolvimento Sustentável para o Estado de Rondônia (PDES-RO), e nele o Observatório de Desenvolvimento Regional (ODR), como um dispositivo de armazenamento de informações, avaliação das políticas do governo e para servir como elo de mediação entre o governo e a sociedade civil.

Após essa síntese do percurso que considerou concepções e projetos de desenvolvimento regional, consolidaram-se alguns elementos para dar resposta ao problema da pesquisa, ou seja, de que forma ocorre a política de mediação entre governo do Estado e a sociedade civil? Os conhecimentos produzidos têm servido para a formulação e implantação de políticas públicas na concepção do desenvolvimento regional sustentável para o estado de Rondônia?

Com relação à mediação, mesmo diante das novas Tecnologias da Informação e da Comunicação (TICs), o governo de Rondônia admite que não implantou instrumentos de mediação que permitam estabelecer diálogos permanentes com a sociedade civil e destaca que somente existe diálogo com a sociedade civil por ocasião do planejamento do Plano Plurianual (PPA).

Já o Observatório de Desenvolvimento Regional (ODR) mesmo sendo definido como um dispositivo de armazenamento e que serviria como um elo de mediação, não tem sido valorizado como tal visto que não existe uma definição política favorável ao seu 
funcionamento conforme as atribuições determinadas pelo PDES-RO, ou esse instrumento foi esvaziado e dessa forma não vem servindo como um elo mediador das políticas do governo com a sociedade civil.

O estado de Rondônia embora tenha sido o primeiro estado da federação a aprovar uma lei de Zoneamento Sócio-Econômico-Ecológico (ZSEE-RO) com terras para cultivo, Unidades de Conservação (UC) e as Terras Indígenas (TI), verifica-se a inexistência de política de fiscalização e de preservação dessas áreas demarcadas. O que se constata é a ocupação ilegal das terras públicas por fazendeiros, com a consequente geração de conflitos no campo e o desmatamento ilegal. No primeiro semestre de 2020, o governo realizou a revisão fundiária da $2^{\mathrm{a}}$ aproximação do ZSEE-RO, objetivando a legalização das áreas públicas e de área de preservação, sendo aprovada no Conselho de Desenvolvimento Ambiental, faltando ser regulamentado na Assembleia Legislativa do Estado (ALE).

Outro fator que chama atenção na região é a falta regularização fundiária, não permitindo que os agricultores tenham acesso ao crédito bancário nem que se estabeleçam com segurança em suas áreas. Essa falta de regulação fundiária tem proporcionado a prática da grilagem e invasão de terras públicas por grandes fazendeiros.

Conforme demonstrado, houve grande avanço da pecuária de corte e de leite, bem como da soja, milho e café clonal na região. A lavoura de soja vem ocupando o espaço antes da pecuária, de forma mecanizada, e os plantadores de soja vêm arrendando e/ou comprando as terras dos pequenos agricultores familiares, e esses estão migrando para o sul do Amazonas ou para o Acre. A produção de soja tem sido exportada para vários países, da mesma forma que o gado de corte.

Já a agricultura familiar, ou pequena propriedade embora represente $85 \%$ das propriedades rurais e o governo mantenha o discurso de apoio à agricultura familiar, verificase a inexistência de política de transferência de tecnologia no campo para esse setor, além da falta de condições para que os jovens permaneçam morando e trabalhando no campo. Dessa forma, sem equipamentos comunitários, muitos agricultores estão vendendo seus lotes para os plantadores de soja e migrando do campo para as cidades e para outros estados.

Como fechamento do presente trabalho, pode-se afirmar que a hipótese levantada inicialmente se confirma, pois existe um distanciamento grande entre o discurso e a prática do governo, tanto federal quanto estadual. Verificou-se que as políticas adotadas desde a década de 1960 pelo governo federal visando à ocupação das fronteiras foram na perspectiva de mobilizar a população excluída visando o seu deslocamento para essas paragens do Oeste brasileiro; no primeiro momento a mobilização se deu no nordeste e posteriormente se 
incentivou várias regiões brasileiras para migrar para esta região como se fosse um "Novo Eldorado", porém na prática eram para servir de mão-de-obra às empresas que vinham ocupar o território com grandes propriedades de terras.

Fica claro que o governo estadual, estimulado pelo governo federal e pelas agências internacionais de fomento, visando à implementação do desenvolvimento sustentável, se constituía na lógica do sistema capitalista internacional, ou seja, que deviam se ocupar as regiões mais distantes, proporcionar o zoneamento social e ambiental, porém na prática sempre se estimulou o agronegócio visando à exportação para os países do norte e recentemente para os países asiáticos. Órgãos como o ODR, que se apresentavam como espaços de mediação de informação e articulação entre atores, não assumiram esse protagonismo na prática, ficando relegados a instâncias burocráticas.

Dessa forma, é possível afirmar que no estado de Rondônia foi utilizado, desde a sua criação, o discurso de preservação ambiental e o discurso de desenvolvimento regional sustentável, porém o governo vem valorizando e incentivando as commodities. Além disso, constata-se agressão às áreas demarcadas para preservação ambiental e às terras indígenas.

Não há políticas voltadas para a mediação, tanto a de informações como as relacionadas à facilitação da interação entre os atores. Apesar das facilidades proporcionadas pelas Tecnologias da Informação e da Comunicação (TICs), não há interesse político em realizar essa forma de aproximação, ou seja, o governo prefere implantar políticas que venham ao encontro do capital financeiro nacional e internacional.

Com relação à sociedade civil, percebe-se que se na década de 1990, o Fórum de ONGs aglutinou os vários setores da sociedade civil e dessa forma se definiu o Zoneamento Sócio-Econômico-Ecológico de Rondônia (ZSEE-RO), com um viés social, contudo, na atualidade, mesmo com as TICs, não se percebe atuação na disputa do campo para garantir diálogos permanentes com a sociedade política. Nesse sentido, no campo pela disputa hegemônica, o governo, além de não criar elos de mediação, não vem reconhecendo entidades da classe subalterna como interlocutoras, preferindo dialogar com as representações do capital econômico, ligado à indústria e à pecuária. 


\section{REFERÊNCIAS}

AGENDA 21: Conferência das Nações Unidas sobre Meio Ambiente e Desenvolvimento. 2 Ed, Brasília: Gráfica do Senado, 1997.

ALMEIDA, Jalcione. Da ideologia do progresso à ideia de desenvolvimento (rural) sustentável. IN: ALMEIDA, Jalcione; NAVARRO, Zander (Orgs.). Reconstruindo a Agricultura: Ideias e ideais na perspectiva do desenvolvimento rural sustentável. 2 Ed, Porto Alegre: Ed. Universidade/UFRGS, 1998.

ALMEIDA, Marco Antônio de. Informação, cultura e sociedade: reflexões sobre a Ciência da Informação a partir das Ciências Sociais. In: LARA, Marilda Lopes Ginez de; FUJINO, Asa; NORANHA, Daisy Pires (Orgs.). In: Informação e Contemporaneidade: Perspectivas. Recife: NÉCTAR, 2007.

ALMEIDA, Marco Antônio de. A produção social do conhecimento e as lições de Bourdieu para a Ciência da Informação. InCID: R. Ci. Inf. e Doc., Ribeirão Preto, v. 8, n. 2, p. 220-224, set. 2017/fev. 2018.

ALMEIDA, Marco Antônio de; CRIPPA, Giulia. De Bacon à internet: considerações sobre a organização do conhecimento e a constituição da ciência da informação. Ponto de Acesso, Salvador, v.3.n.2, p. 109-131, ago.2009.

ALMEIDA, Marco Antônio de. Mediação e mediadores nos fluxos tecnoculturais contemporâneos. Inf. e Inf. Londrina, v.19, n.2, p.191-214, maio/ago.2014 - http: www.uel.br/revista/informacão/.

ALMEIDA, Marco Antônio de; DAMIAN, Ieda Pelógia Martins. HUMANIDADES DIGITAIS: UM CAMPO PRAXIOLÓGICO PARA MEDIAÇÕES E POLÍTICAS CULTURAIS. XVI Encontro Nacional de Pesquisa em Ciência da Informação (XVI ENANCIB). ISSN 2177-3688: João Pessoa-PB, 26 a 30 de outubro de 2015.

ALBAGLI, Sarita; MACIEL, Maria Lucia. Informação e conhecimento na inovação e no desenvolvimento local. Ci. Inf. Brasília, v. 33, n.3, p.9-16, set./dez.2004.

ALBURQUERQUE, Francisco e ZAPATA, Tania. A importância da estratégia de desenvolvimento local/territorial no Brasil. In: (Org.) DOWBOR, Ladislau e POCHMANN, Marcio. Políticas para o desenvolvimento local. Editora Perceu Abramo: São Paulo: 2010.

AMARAL, Cristiano Torres do; MORET, Artur de Souza, e MARTA, José Manuel Carvalho. Ateliê Geográfico - Goiânia-GO, v.12, n.2, ago/2018, p.249-268. Disponível em: $<$ https://www.revistas.ufg.br/atelie/article/view/45037/26579>. Acesso em: 10/03/2020.

Amigos da Terra Internacional - Programa Amazônia; Oxfam - Associação Recife-Orford para a Cooperação ao Desenvolvimento. Análise Crítica da Implementação do Plano Agropecuário e Florestal de Rondônia um Ano Após o Acordo para sua Reformulação: Planafloro um ano depois. São Paulo, 1997.

ANDRADE, Adilson Siqueira de. ONGs e Desenvolvimento Regional em Rondônia. 2010. 141 f. Dissertação (Mestrado em Antropologia). Universidade Federal de Pernambuco, Recife, 2001.

ARAÚJO, Carlos Alberto Ávila. O que é ciência da informação. Belo Horizonte: KMA, 2018.

ARAUJO, Carlos Alberto Ávila. Correntes teóricas da ciência da informação. Ci. Inf. Brasília. DF, v.38, n.3.p.192-204, set/dez, 2009. 
ATLAS DE CONFLITOS NA AMAZÔNIA: Articulação das CPT's Amazônia (Org.). Comissão Pastoral da Terra - CPT. São Paulo: Entremares, 2017.

ATHIAS, Renato. A Noção de Identidade Ética na Antropologia Brasileira: de Roquette Pinto a Roberto Cardoso de Oliveira. Recife: Ed. Universitária da UFPE, 2007.

ATHIAS, Renato. Relatório Avaliativo dos Planos Operacionais Anuais do Componente Indígena do Planafloro. Comitê de Avaliação Independente (COMAI), BIRD, mimeo, 1993.

BARATTA, Giorgio. ANTONIO GRAMSCI em contraponto. São Paulo: Ed. Unesp, 2011.

BARBIERI, José Carlos. Desenvolvimento e Meio Ambiente: As Estratégias de Mudanças da Agenda 21, 2 edição, Petrópolis: Ed. Vozes, 1998.

BARRETO, Aldo de Albuquerque. Globalização e novas tecnologias: As novas tecnologias de informação e a geração do conhecimento. Comun. inf., v.l, n. 1, p. 11-17, jem./jun. 1998.

BARTHOLO JR.Roberto S.; BURSZTYN, Marcel. Amazônia Sustentável: Estratégia de Desenvolvimento Rondônia 2020. Brasília: Ed. IBAMA, 1999.

BATISTA, Paulo Nogueira. O Brasil e o Desenvolvimento Sustentável. In: D’INCAO, Maria Ângela; SILVEIRA, Isolda Maciel da. (Org.). A AMAZÔNIA E A CRISE DA

MODERNIZAÇÃO. Belém: Museu Paraense Emílio Goeldi, 1994.

BECHER, Bertha K. Amazônia: Geopolítica na virada do III milênio. Rio de Janeiro: Garamond, 2004.

BECKER, Bertha K; MIRANDA, Mariana; MACHADO, Lia Osório (Orgs.). Fronteira Amazônica: Questões Sobre a Gestão do Território. Brasília: Ed. UnB, 1990.

BINSWANGER, Hans Christophe. Fazendo a Sustentabilidade Funcionar. In: CAVALCANTI, Clovis (Org.). MEIO AMBIENTE DESENVOLVIMENTO SUSTENTÁVEL E POLÍTICAS PÚBliCAS. 2 Ed, São Paulo/Recife: Ed. Cortez/Fundação Joaquim Nabuco, 1999.

BOBIO, Norberto. Estado Governo Sociedade: para uma teoria geral da política. Trad. Marco Aurélio Nogueira. 6 Ed, Rio de Janeiro: Paz e Terra, 1987.

BOURDIEU, Pierre. O Poder Simbólico. Editora Difel: Rio de Janeiro, 1989.

BOURDIEU, Pierre. Razões Práticas: sobre a teoria da ação. Trad. Mariza Corrêa. 11 Ed, Campinas-SP: Papirus, 2011.

BOURDIEU, Pierre. Sobre o Estado: curso no Collège de France (1989-92). Trad. Rosa Freire d’Aguiar. 3 Ed. São Paulo: Cia das Letras, 2014.

BOURDIEU, Pierre. Economia das trocas simbólicas. Sergio Miceli (Org.) 8 Ed. São Paulo: Perspectiva S.A, 2015.

BOURDIEU, Pierre. Coisas Ditas. Trad. Cássia R. da Silveira e Denise Moreno Pegorim. 3 Ed. São Paulo: Brasiliense, 2015.

BOURDIEU, Pierre. A produção da crença: contribuição para uma economia dos bens simbólicos. Trad. Guilherme João de Freitas Teixeira. Porto Alegre: Zouk, 2015.

BOURDIEU, Pierre. A dominação masculina: a condição feminina e a violência simbólica. Trad. Maria Helena Kuhner. 15 Ed. Rio de Janeiro: Bertrand Brasil, 2019. 
BRANDÃO, Carlos Antônio (Org.). Teorias e políticas do desenvolvimento latino-americano. Rio de Janeiro: Contraponto: Centro Internacional Celso Furtado de Politicas para o Desenvolvimento, 2018.

BRAMAN, Sandra. A Economia representacional e o regime global da política de informação. In: Informação, conhecimento e poder: mudança tecnológica e inovação.

MACIEL, Maria Lucia; ALBAGLI, Sarita (Orgs.). Rio de Janeiro: Garamond, 2011.

BRANDENBURG. Alfio. Agricultura família. ONGs e o desenvolvimento sustentável. Curitiba: Ed.da UFPR, 1999.

BRAGA, Denise Bértoli (Org.). Tecnologias Digitais da Informação e Comunicação e Participação Social. São Paulo: Cortez Editora, 2015.

BURAWOIY, Michel. O marxismo encontra Bourdieu. (Org.) NETO, Ruy Gomes Braga, (Trad. Fernando Rogério Jardim). Campinas-SP: Editora da UNICAMP, 2010.

BURSZTYN, Marcel (Org.). Para pensar o Desenvolvimento Sustentável. 2 Ed, São Paulo: Ed. Brasiliense, 1994.

BURKE, Peter. Uma História Social do Conhecimento I: De Gutenberg a Diderot. Trad. Plinio Dentzien. Rio de Janeiro: Zahar, 2003.

BURKE, Peter. Uma História Social do Conhecimento II: Da Enciclopédia à Wikipédia. Trad. Denise Bottmann. Rio de Janeiro: Zahar, 2012.

CAPURRO, Rafael. Epistemologia e ciência da informação. In: ENCONTRO NACIONAL DE PESQUISA EM CIÊNCIA DA INFORMAÇÃO, Belo Horizonte (Brasil) 10 de novembro de 2003. Tradução de Ana Maria Rezende Cabral, Eduardo EENSE Dias, Isis Paim, Ligia Maria Moreira Dumont, Marta Pinheiro Aun e Mônica Erichsen Nassif Borges. Versiónorginal em castellano aqui Presentacion: PowePoint.

CAPPUCI, Flavio. Antônio Gramsci: Caudernos de la Carcel (Análise de "El materialismo histórico y la filosofia de Benedetto Croce") Ed. Gráficas Reunidas: S.A.Madrid, 1978.

CARDOSO, Fernando H. MULLER, G. Amazônia: Expansão do Capitalismo. 2 Ed, São Paulo: Ed. Brasiliense, 1978.

CARVAlHO, Horácio Martins de. Avaliação final do PLANAFLORO. Porto Velho/Curitiba, 2002.

CARVALHO, Horácio Martins. Resgate Histórico e Avaliação do Fórum das Organizações Não-Governamentais e Movimentos Sociais que Atuam em Rondônia (Relatório), Porto Velho/Curitiba, 1996.

CASTIEL, Sandra Maria Magalhães Costa. Raízes de Rondônia. Porto Velho, 1990.

CASTELLS, Manuel. A sociedade em rede: do conhecimento à política. In: CASTELLS, Manuel e CARDOSO, Gustavo (Orgs.). A Sociedade em Rede: Do conhecimento à Ação Política Imprensa Nacional-Casa da Moeda, 2006.

CASTRO, Edna; PINTON, Florence. (Orgs.). Faces do Trópico Úmido: Conceito e questões sobre Desenvolvimento e Meio Ambientes: Belém: Ed. Cejup, Naea/Ufpa, 1997.

CATARI, Afrânio Mendes (et al.) (Org.). Vocabulário BOURDIEU. Belorizonte: Autêntica Editora, 2017.

CAVALCANTI, Clóvis. Política de Governo para o Desenvolvimento Sustentável: Uma Introdução ao tema e a esta obra coletiva. In: CAVALCANTI, Clovis (Org.). MEIO 


\section{AMBIENTE DESENV OLVIMENTO SUSTENTÁVEL E POLÍTICAS PÚBLICAS, 2}

Ed, São Paulo/Recife: Ed. Cortez/Fundação Joaquim Nabuco, 1999.

CAVAlCANTI, Clóvis. (Org.) Meio Ambiente Desenvolvimento Sustentável e Políticas Públicas. 2 Ed, Cortez: Recife: Ed. Fund. Joaquim Nabuco, 1999.

CAVALCANTI, Josefa Salete Barbosa (Org.). Globalização Trabalho Meio Ambiente: Mudanças Socioeconômicas em Regiões Frutícolas para Exportação. Recife: Ed. UFPE, 1999.

CHIAVENATO, Júlio José. O Massacre da Natureza. 12 Ed, São Paulo: Ed. Moderna, 1995.

CHRISTOFFOLI, Pedro Ivan. A luta pela terra e o desenvolvimento local no Brasil. In: (Org.) DOWBOR, Ladislau e POCHMANN, Marcio. Políticas para o desenvolvimento local. Editora Perceu Abramo: São Paulo: 2010.

CHOO, Chu Wei. A Organização do Conhecimento: Como as organizações usam a informação para criar significado, construir conhecimento e tomar decisões. Trad. Eliana Rocha. São Paulo: Senac, 2003.

COELHO, Franklin Dias. Desenvolvimento local e sociedade da informação. In (Orgs.). DOWBOR, Ladislau e POCHMANN, Marcio. Políticas para o desenvolvimento local. São Paulo: Editora Perceu Abramo, 2010.

COELHO, Maria Célia Nunes. Cidades da Amazônia em busca de novas interpretações e de novos rumos. In: FATHEUER, T.; ARROYO, J.C.; MACHADO, J.A.da C. (Coord.). Amazônia: Estratégias de Desenvolvimento Sustentável, Uma Contribuição para a Elaboração de Planos de Desenvolvimento e Agenda 21. Núcleo de Comunicação e Marketing da UNIPOP. (1998). Cap. 1.

CONSELHO NACIONAL DOS DIREITOS HUMANOS - CNDH. Relatório da Missão realizada em junho/2016 pelo Grupo de Trabalho sobre Defensores de Direitos Humanos Ameaçados no Estado de Rondônia, criado no âmbito da Comissão Permanente de Defensores de Direitos Humanos e Enfrentamento à Criminalização dos Movimentos Sociais, do Conselho Nacional dos Direitos Humanos. Scs-B Quadra 09 Lote C - Edifício Parque Cidade Corporate - Torre A, 10 Brasília/Df, 2016.

COSTA, Maria José Jackson. Demografia e Mão-de-obra na Amazônia. Belém: Edneia/Upa, 1990.

COSTA, Francisco de Assis. Ciência, Tecnologia e Sociedade na Amazônia: Questões para o desenvolvimento sustentável. Belém: Ed. Cheju, 1998.

COUTINHO, Carlos Nelson. Gramsci: um estudo sobre seu pensamento político. 3 Ed. Rio de Janeiro: Civilização brasileira, 2007.

COUTINHO, Carlos Nelson; TEIXEIRA, Andréa de Paula (Orgs.). Ler Gramsci, entender a realidade. Rio de Janeiro: Civilização brasileira, 2003.

CUNHA, Eliaquim Timotéo da; MOSER, Lilian Maria. OS PROJETOS DE COLONIZAÇÃO EM RONDÔNIA. Revista Labirinto - Ano X, nº 14 - dezembro de 2010. Disponível em: http://www.periodicos.unir.br/index.php/LABIRINTO/article/viewFile/938/922. Acessado em 19/10/2020. 
DEMO, Pedro. Metodologia Científica em Ciências Sociais. 3 Ed. São Paulo: Atlas S.A, 1995.

DÍAZ-SALAZAR, Rafael. El Proyecto de Grossi. Madrid: Editora Anthropos, 1991.

DUMONT, Louis. O Individualismo: Uma Perspectiva antropológica da ideologia Moderna. (Trad. Álvaro Cabral), Rio de Janeiro J Ed.Rocco, 1985.

Estimativa da população em Rondônia (2020). Disponível em:

<https://www.ibge.gov.br/cidades-e-estados/ro/>. Acesso em: 19/10/2020.

ECO. Humberto. Como se faz uma tese. 11 Ed. São Paulo: Editora Perspectiva S.A, 1994.

FATHEUER, Thomas; João Claudio Arroyo. Desenvolvimento Sustentável - Elementos para Discussão. In: FATHEUER, T.; ARROYO, J.C.; MACHADO, J.A.da C. Coord. Amazônia: Estratégias de Desenvolvimento Sustentável, Uma Contribuição para a Elaboração de Planos de Desenvolvimento e Agenda 21. Belém: Núcleo de Comunicação e Marketing da UNIPOP, 1998.

FEARNSIDE, Philip M. Hidrelétricas na Amazônia: impactos ambientais e sociais na tomada de decisões sobre grandes obras. Manaus: Editora do INPA, 2015, vol. 1.

FERRI, Franco (Instituto Gramsci). Política e História em Gramsci. Trad. Luiz Mário Gazzaneo, Rio de Janeiro: Ed. Civilização Brasileira, 1978, Vol. I.

SMERALDI, Roberto. Pedido de investigação apresentado ao Painel de Inspeção do Banco Mundial sobre o PLANAFLORO - Plano Agropecuário e Florestal de Rondônia. Fórum das ONGs e Movimentos Sociais que atual em Rondônia e Friends ofthe Earth Amigos da Terra - Programa Amazônia. Porto Velho, 1995.

FOUCAULT, Michel. Microfísica do Poder. Trad. Roberto Machado, 9 Ed. Rio de Janeiro: Ed. Graal, 1997.

FURTADO, Celso. Formação econômica do Brasil.14 Ed. São Paulo: Cia Editora Nacional, 1976.

FURTADO, Celso. O Brasil "Pós-Milagre". 2 Ed. Rio de Janeiro: Paz e Terra, 1981.

GEERTZ, Clifford. A Interpretação das Culturas. Rio de Janeiro: Editora, Zahar, 1978.

GEERTZ, Clifford. Nova Luz sobre a ANTROPOLOGIA. Trad. Vera Ribeiro, Rio de Janeiro: Jorge Zahar Editor, 2001.

GLUCKSMANN, C.B. Gramsci e o Estado. 2 Ed, Rio de Janeiro; Ed. Paz e Terra, 1990.

GODARD, Olivier. O Desenvolvimento Sustentável: Paisagem Intelectual. In: CASTRO,

Edna; PINTON, Florence, (Cood.). Faces do Tópico Úmido Conceitos e Questões Sobre Desenvolvimento e Meio Ambiente. Belém: Editora Cejup 1997.

GÓMEZ, Maria Nélida González de. Novas fronteiras tecnológicas das ações de informação: questões e abordagens. Ci. Inf., Brasília, v. 33, n. 1, p. 55-67, jan./abril 2004

GÓMEZ, Maria Nélida González. Informação, conhecimento e poder: do ponto de vista das relações entre política, economia e linguagem. In: Informação, conhecimento e poder: mudança tecnológica e inovação. MACIEL, Maria Lucia; ALBAGLI, Sarita (Orgs.). Rio de Janeiro: Garamond, 2011.

GODELIER, Maurice. A Racionalidade dos Sistemas Econômicos. In: FERNANDES, Florestan (Org.), São Paulo: Ed.Ática, 1981. 
GONÇALVES, Carlos Walter. Os (Des) Caminhos do Meio Ambiente. São Paulo: Ed. Contexto, 1989.

GONÇALVES, Carlos Walter. Paixão da Terra: Ensaio Críticos de Ecologia e Geografia. Rio de Janeiro: Ed. Sociedade, 1984.

GRAMSCI, A. Os Intelectuais e a Organização da Cultura. Trad. Carlos Nelson Coutinho, Rio de Janeiro: 8 Ed. Editora Civilização brasileira, 1991.

GRAMSCI, A. Liberalismo e Democracia. Trad. Marcos Aurélio Nogueira, 6 Ed. São Paulo: Ed. Brasiliense: 1998.

GRAMSCI, A. Concepção Dialética da História. Trad. Carlos Nelson Coutinho, 8 Ed. Rio de Janeiro: Civilização Brasileira, 1989.

GRAMSCI, A. Maquiavel, A Política e o Estado Moderno. Trad. Luiz Mário Gazzaneo, 4 Ed. Rio de Janeiro: Editora Civilização brasileira, 1980.

GRAMSCI, A. Obras Escolhidas. Trad. Manuel Cruz. São Paulo: Ed. Martins Fontes, 1978.

GRIGOLETO, Maria Cristina. Informação e Documento: expressão material no patrimônio. InCIB: R. Ci. Inf. e Doc. Ribeirão Preto. V.3.n.1.p.57-69, jan./jun.2012.

GRUPPI, L. O Conceito de Hegemonia em GRAMSCI. Trad. Carlos Nelson Coutinho, 3 Ed. Rio de Janeiro: Ed. Graal: 1981.

HARDMAN, Francisco Foot. Trem Fantasma, a modernidade na Selva. São Paulo: Editora Ciadas Letras, 1991.

HALL, Anthony L.Amazônia: Desenvolvimento para quem? Desmatamento e Conflito Social no Programa Grande Carajás. Trad. Ruy Gungmann. Rio de Janeiro: Ed.Zahar, 1991.

IBGE. Rondônia (2020). Disponível em: 〈https://www.ibge.gov.br/cidades-e-estados/ro/> . Acesso em: 19/10/2020.

LHARENA, Rosilene Agapito da Silva; DUARTE, Eneide Nóbrea; NAVARRO, Miguel, Ángel Esteban. Gestão do Conhecimento nas redes dos programas para a juventude: modelo baseado nas políticas públicas. João Pessoa: Editora da UFPB, 2017.

LARA, Marilda Lopes Ginez; FUJINO, Asa; NORONHA, Daisy Pires (Orgs.). Informação e Contemporaneidade: Perspectivas. Recife: NÉCTAR, 2007.

LATUR, Bruno. Jamais fomos modernos. Trad. Carlos Irineu da Costa. São Paulo: Editora 34, 2016.

LATUR, Bruno. A Esperança de Pandora: ensaios sobrea a realidade dos estudos científicos. Trad. Gilson Cézar Cardoso de Sousa. São Paulo: Editora Unesp, 2017.

LASTRES Helena; ALBAGLI, Sarita. Informação e globalização na era do conhecimento (Orgs.), Rio de Janeiro: Campus, 1999.

LEIS, Héctor R.(Org.). Ecologia e Política Mundial. Rio de Janeiro: Vozes, 1991.

LÉVY, Pierre. As tecnologias da Inteligência: o futuro do pensamento na era da informática. Trad. Carlos Irineu da Costa. 2 Ed. São Paulo: Editora 34, 2010.

LIMA, Abnael Machado de. Terras de Rondônia: Geografia Física e Humana. 2 Ed, Rio de Janeiro: Gráfica IBGE, 1990.

LONG, Normam. Introdução à Sociologia do Desenvolvimento Rural (Trad. Waltensir Dutra) Rio de Janeiro: Ed Zahar, 1982. 
MARTINS, José de Souza. Reforma Agrário o Impossível Diálogo. São Paulo: Ed. EDUSP, 2000.

MARTA, José Manuel Carvalho. Rondônia: da Colonização à Integração Latino-Americana. Cuiabá: edUFMT; Porto Velho: Edufro, 2018.

\section{MARTELETO, Regina Maria. REDES SOCIAIS, MEDIAÇÃO E APROPRIAÇÃO DE}

INFORMAÇÕES: situando campos, objetos e conceitos na pesquisa em Ciência da Informação SOCIAL. Pesq. bras. ci. inf., Brasília, v.3, n.1,p.27-46, jan./dez. 2010.

MARTELETO, Regina Maria; SILVA, Antônio Braz de Oliveira. Redes e capital social: o enfoque da informação para o desenvolvimento local. Ci. Inf., Brasília, v. 33, n. 3, p.41-49, set./dez. 2004.

MARTINS, Rafael D'Almeida; VAZ, José Carlos; CALDAS, Eduardo de Lima. A gestão do desenvolvimento local no Brasil: (des)articulação de atores, instrumentos e território. Rio de Janeiro: Revista de Administração Pública (RAP), 44(3): 559-90, Maio/jun. 2010.

MARTINS, Marcos Francisco. Marx, Gramsci e o conhecimento: ruptura ou continuidade? Campinas-SP: UNISAL, 2008.

MAZZUCATO, Mariana. O Estado Empreendedor: desmascarando o mito do setor público vs. setor privado. (Trad. SERAPICOS, Elvira), 2014.

McGRATH, David G. Biosfera ou Biodiversidade: Uma avaliação Crítica do Paradigma da Biodiversidade. In: XIMENES, Tereza (Org.) Perspectivas do DESENVOLVIMENTO SUSTENTÁVEL - Uma contribuição para a Amazônia 21, Belém: NAEA/UFPa, 1997.

MEANTE, Raica Esteves Xavier e DÓRIA Carolina Rodrigues da Costa.

CARACTERIZAÇÃO DA CADEIA PRODUTIVA DA PISCICULTURA NO ESTADO

DE RONDÔNIA: desenvolvimento e fatores limitantes. Revista de Administração e Negócios da Amazônia, V.9, n.4, set/dez, 2017 ISSN:2176-8366 DOI 10.18361/21768366/rara.v9n4p164-181 164.

MELUCCI, Alberto. A invenção do presente: movimentos sociais nas sociedades complexas. Trad. Maria do Carmo Alves Bomfim. Petrópolis-RJ: Vozes, 2001.

MENDES, Armando D.\& SANCHS, Ignacy. A Inserção da Amazônia no Mundo. In: CASTRO, Edna \&PINTON, Florence. (Org.) FACES DO TRÓPICO ÚMIDO Conceito e questões sobre Desenvolvimento e Meio Ambiente. Belém: Ed. Cejup, Naea/Ufpa, 1997.

MIRANDA, Marcos Luiz Cavalcanti de; RIBEIRO, Maria Cristina Paiva. Os princípios otletianos na gestão da informação e do conhecimento. In: As Contribuições de Paul Otlet para a Biblioteconomia. PEREIRA, Ana Maria Silveira Kroeff; CORREA, Elisa Cristina Delfini (Orgs.). Florianópolis (SC): 2018.

MOISÉS, José Álvaro et al. Contradições Urbanas e Movimentos Sociais. 2 Ed, Ed. Paz e Terra, 1978.

MORÁN, Emílio F. A Ecologia Humana das Populações da Amazônia. Vozes: Petrópolis, 1990.

MOREIRA, Alberto da Silva (Org.). Sociedade Global Cultura e Religião. 2 Ed, Petrópolis: Ed. Vozes, 1999.

NITSCH, Manfred. Riscos do Planejamento Regional na Amazônia Brasileira: Observações Relativas à Lógica Complexa do Zoneamento. In: D’INCAO, Maria Angela \& SILVEIRA, 
Isolda Maciel da. (Org.). A AMAZÔNIA E A CRISE DA MODERNIZAÇÃO, Museu Paraense Emílio Goeldi: Belém, 1994.

NOSSA PRÓPRIA AGENDA. Comissão de Desenvolvimento e Meio Ambiente da América Latina e do Caribe. BID, PNUD.

OLIVEIRA, Ruth Helena Rocha. A reforma agrária e suas implicações no processo de desenvolvimento do estado de Rondônia. Dissertação (Mestrado em Administração Pública). Fundação Getúlio Vargas. Rio de Janeiro, 1994.

OLIVEIRA, Roberto Cardoso de. Práticas Interétnicas e Moralidade. In: ARANTES, Antônio, Guilherme R.Ruben; Guita G. Debert (Orgs.). Desenvolvimento e Direitos Humanos: A Responsabilidade do Antropólogo, Ed. da Unicamp, Campinas-SP, 1992.

OLIVEIRA, Roberto Cardoso de. O trabalho do Antropólogo. São Paulo: Ed. UNESP, 2006.

PÁdUA, José Augusto (Org.) Ecologia \& Política no Brasil. 2 Ed. Rio de Janeiro: Ed. Espaço e Tempo/IUPERJ, 1992.

PADULA, Raphael. DA IIRSA AO COSIPLAN DA UNASUL: A integração de infraestrutura na América do sul nos anos 2000 e suas perspectivas de mudança. In: O Brasil e novas dimensões da integração regional. (Org.) NETO, Walter Antônio Desiderá. Rio de Janeiro: IPEA, 2014.

PASSOS, Messias Modesto dos. Amazônia: Teledetecção e Colonização. São Paulo: Editora UNESP.

PANAYOTOU, Theodore. Mercado Verde: A Economia do Desenvolvimento Alternativo, Rio de Janeiro: Ed. Nórdica, 1994.

PINTO, Emanuel Pontes. Rondônia: Evolução Histórica - Criação do Território de Guaporé, fator de Integração Nacional. Rio de Janeiro: Ed. Expressão Cultural, 1993.

PINTO, Lúcio Flávio. Amazônia: No Rastro do Saque. São Paulo: Ed. Hucitec, 1980.

PLANO DE DESENVOLVIMENTO ESTADUAL SUSTENTÁVEL DE RONDÔNIA 2015-2030 (PDES). Disponível em:

http://www.sepog.ro.gov.br/Uploads/Arquivos/PDF/PDES/26.11.\%20PLANO\%20DE\%20D

ESENVOLVIMENTO\%20ESTADUAL\%20SUSTENT\%C3\%81VEL\%20DE\%20ROND.pdf $>$ Acesso em: 24/06/2018.

PORTELLI, Hugues. GRMASCI e o Bloco histórico. Trad. Angelina Peralva. 6 Ed. Rio de Janeiro: Paz e Terra, 1977.

PROGAMA AMAZÔNIA de Amigos da Terra e OXFAM. Análise Crítica da Implementação do Plano Agropecuário e Florestal de Rondônia um Ano Após o Acordo para sua Reformulação. PLANAFLORO Um Ano Depois. São Paulo/e P. Velho, 1997.

QUEIROZ, Fernanda Mendes; NORONHA. Daisy Pires. Temática das dissertações e teses em ciência da informação no Programa de Pós-Graduação em Ciências da Comunicação da USP, 2004.

RAHNEMA, Majid; BAWTREE, Victoria.The Pos-Development Reader. Canada: Fernwood Publishing Ltda, 1997.

RELATÓRIO N. ${ }^{\circ}$ 8073-BR. Documento do Banco Mundial. Relatório da Equipe de Avaliação Brasil - Projeto de Manejo dos Recursos Naturais de Rondônia. Divisão de 
Operações da Agricultura, Departamento de Países I, América Latina e a Região do Caribe. 1992.

RONDON, Major Frederico. Na Rondônia Ocidental. Rio de Janeiro: Ed. Cia Editora Nacional, 1938.

RONDÔNIA. Governo do Estado de Rondônia. Secretaria de Estado do

Desenvolvimento e Meio Ambientes. Zoneamento socioeconômico e ecológico de Rondônia será apresentado em reunião com integrantes da Comissão Estadual. DISPONÍVEL EM: $<$ http://www.sedam.ro.gov.br/zoneamento-socioeconomico-e-ecologico-de-rondonia-seraapresentado-em-reuniao-com-integrantes-da-comissao-estadual/>>. Acessado em: $15 / 05 / 2019$.

RONDÔNIA. Governo do estado de Rondônia. Portal sobre o Observatório Estadual de Desenvolvimento Regional (ODR). 2018. Disponível em:

<www.odr.ro.gov.br/c/odr/6f9a06ac-8eed-e811-80c5-000c290fa8ce>. Acesso em: $13 / 05 / 2019$.

RONDÔNIA. Governo do Estado de Rondônia. Secretaria de Estado do Desenvolvimento Ambiental. 21 anos de Zoneamento Socioeconômico e ecológico do Estado de Rondônia: planejamento para o desenvolvimento e proteção ambiental, SEDAM. Porto Velho, 2010.

RONDÔNIA. Governo do Estado de Rondônia. Secretaria de Estado do Planejamento, Coordenação Geral e Administração. PLANAFLORO: zoneamento socioeconômicoecológico de Rondônia. SEPLAD: Porto Velho, 2000.

RONDONIA. Governo do Estado de Rondônia. Secretaria de Estado da Agricultura. SEAGRI. "Secretaria de Agricultura destaca o desenvolvimento das cadeias produtivas prioritárias de Rondônia”. Disponível em: <http://www.rondonia.ro.gov.br/secretaria-deagricultura-destaca-o-desenvolvimento-das-cadeias-produtivas-prioritarias-de-rondonia/ Acessado em: 19.10.2020.

RONDONIA. Governo do Estado de Rondônia. Secretaria de Estado do Planejamento Orçamento e Gestão. SEPOG. "Implantação da ferramenta Observatório Estadual avança em Rondônia”. Disponível em:

http://sepog.ro.gov.br/Noticia/Exibir/1043?titulo=Implanta\%C3\%A7\%C3\%A30\%20da\%20fe rramenta\%20Observat\%C3\%B3rio\%20Estadual\%20avan\%C3\%A7a\%20em\%20Rond\%C3\% B4nia\&nome=GDPP. Acessado em: 19.10.2020.

ROIO, Marcos Del (Org.). GRAMSCI: periferia e subalternidade. São Paulo: Editora da USP, 2017.

RUA, Maria das Graças. Desafios da administração pública brasileira: governança, autonomia, neutralidade. Revista do Serviço Público (RSP). Ano 48, No 3. Set-Dez. 1997.

RUSCHE, Ana; SANTINI, Daniel. Plataformas de solidariedade: a diferença entre transformar tudo em objeto de lucro e compartilhar de maneira inteligente. IN: SCHOLZ, Trebor. Cooperativismo de plataforma: contestando a economia do compartilhamento corporativa. Trad. Trad. ZANATTA, Rafael, A. São Paulo: Fundação Rosa Luxemburgo; Editora Elefante; Autonomia Literária, 2016.

SACHS, Ignacy. Ecodesenvolvimento: Crescer Sem Destruir. Trad. Aneida Araújo. São Paulo: Ed. Vértice, 1986. 
SACHS, Ignacy. Prefácio. In: PÁDUA, José Augusto (Org.). Desenvolvimento, justiça e meio ambiente. Belo Horizonte: Editora UFMG; São Paulo: Editora Peirópolis, 2009.

SACHS, Ignacy. Caminhos para o desenvolvimento sustentável. Trad. José Lins Albuquerque Filho. Rio de Janeiro: Garamond, 2000.

SACHS, Ignacy. Desenvolvimento: De modelo em crise no fim do século XX a ideia forte para o século XXI. In: FORMIGA, Marcos; SACHS, Ignacy. (Orgs.). Celso Furtado: a SUDENE e o Futuro do Nordeste (Seminário Internacional). Recife: Sudene, 2000.

SACHS, Ignacy. Desenvolvimento includentes, sustentável sustentado. Rio de Janeiro: Garamond, 2004.

SACHS, Wolfgang. Dicionário do Desenvolvimento: guia para o conhecimento como poder. Trad. Vera Lúcia M. Joscelyne, Susana de Gyalokay e Jaime A. Clasen. Petrópolis: Editoras Vozes, 2000.

SACHS, Ignacy. Sociedade, Cultura e Meio Ambiente. Mundo \& Vida vol.2 (1) 2000.

SALETI, Eneas (Org.) Amazônia: Desenvolvimento, integração brasileira. São Paulo: CNPq, 1983.

SALLES, Waldemar Batista. O Amazonas e o meio físico e suas riquezas naturais. 3 Ed: Manaus Imprensa Oficial.

SANTOS, Boaventura de Sousa. A Cruel Pedagogia do Virus. Coimbra/Portugal: Ed. Almedina, 2020.

SANTOS, Milton. A Natureza do Espaço: Técnica e Tempo- razão e emoção. 3 Ed, São Paulo: Ed. Hucitec, 1995.

SANTOS, Milton. Técnica Espaço, Tempo: Globalização e Meio técnico-científico informacional. São Paulo: Ed. Hucitec, 1997.

SANTOS, João Vitor. Garimpeiros, grileiros e madeireiros não fazem quarentena e avançam sobre a floresta e povos indígenas. Entrevista especial com Dom Roque Paloschi. Disponível em: < http://www.ihu.unisinos.br/159-noticias/entrevistas/598636-garimpeirosgrileiros-e-madeireiros-nao-fazem-quarentena-e-avancam-sobre-a-floresta-e-povos-indigenasentrevista-especial-com-dom-roque-paloschi. Acesso em: 20 de maio 2020.

SCHERER-WARREN, Ilse. Movimentos Sociais Um ensaio de interpretação sociológica. 2 Ed. Florianópolis: Editora da ufsc, 1987.

SEMERARO, Giovanni. GRAMISCI e os novos embates da filosofia da práxis. Aparecida-SP: Ideias \& Letras, 2006.

SERACEVIC, Tefko. Ciência da Informação: origem, evolução e relações. Perspectiva. Ci. Inf., Belo Horizonte, v. 1, n. 1, p. 41-62, jan./jun. 1996.

SCHWARZ, Dorothy; SCHWARZ, Walter. Ecologia: Alternativa para o futuro. (Trad. Maria Inês Rolim), Rio de Janeiro, 1990.

SIQUEIRA S.J., Josafá Carlos de. Ética Ambiental e Crise Planetária. In: CHAUVEL, Marie GOHEN, Marcos; CHAUVEL, Marie Agnes (Orgs.). Ética Sustentabilidade e Sociedade: desafios de nossa era. Rio de Janeiro: Mauad, 2009.

SILVA, Ricardo Gilson da Costa. Agentes, processos e conflitos na gestão territorial no estado de Rondônia (Brasil). In: SILVA, Ricardo Gilson da Costa, (Org.). Porto Velho: cultura, natureza e território. Porto Velho: Temática/Edufro, 2018. 
SILVA, Amizael Gomes. No Rastro dos Pioneiros: Um pouco da história rondoniana. SEDUC. Porto Velho, 1984.

SILVEIRA, Rogério Leandro Lima da; FELIPPI, Ângela Cristina Trevisan; CAMPOS, Heleniza Ávila. O OBSERVATÓRIO DO DESENVOLVIMENTO REGIONAL: a construção de uma rede de pesquisa e extensão sobre a dinâmica do desenvolvimento regional brasileiro. In: SILVEIRA, Rogério Leandro Lima da (Org.). OBSERVANDO O DESENVOLVIMENTO REGIONAL BRASILEIRO: PROCESSOS, POLÍTICAS E PLANEJAMENTO. Santa Cruz do Sul: EDUNISC, 2013.

SMERALDI, Roberto (Coord.) Fórum de ONGs e Mov.Soc. que Atuam em Rondônia e Friends ofthe Eart. Pedido de Investigação apresentado ao Painel de Inspeção do Banco Mundial sobre o PLANAFLORO. Porto Velho, 1995.

SOARES, Felipe Menezes. O governo Médici e o programa de integração nacional (norte e nordeste) - DISCURSOS E POLÍTICAS GOVERNAMENTAIS (1969-1974) (Dissertação de Mestrado) Universidade Federal de Pernambuco (UFPE), Recife-Pe, 2015.

SPANGENBERG Joachim H. Por um Conceito Integrado de Sustentabilidade. In: FATHEUER, T.; ARROYO, J. C; MACHADO, J. A. da C.(Org.). Amazônia: Estratégias de Desenvolvimento Sustentável, Uma Contribuição para a Elaboração de Planos de Desenvolvimento e Agenda 21. Belém: Núcleo de Comunicação e Marketing da UNIPOP, 1998.

STAVENHAGEN, Rodolfo. Etnodesenvolvimento: Uma Dimensão Ignorada no Pensamento Desenvolvimentista. Anuário Antropológico n.84. Ed. Tempo Brasileiro 1985.

STAVENHAGEN, Rodolfo. Sete teses equivocadas sobre América Latina. Soc. e Cult., Goiânia, v.17, n.1, p.159-169, jan/jun.2014.

STOLERMAN, Paula; SANTOS, Sheila Castro dos; SILVA, Admilson de Almeida; FLORIANI, Nicolas. A implantação da Usina Hidrelétrica de Jirau no rio Madeira e os processos de desterritorialização em Rondônia. Terr@Plural, Ponta Grossa, v.8, n.2, p. 371-387, jul/dez. 2014.

TENÓRIO, Fernando G. Gestão de. ONGs Principais Funções Gerenciais. Rio de Janeiro: Ed. Fundação Getúlio Vargas, 1997.

TEXEIRA, Marcos A. D. Prefácio. IN: PINTO, Emanuel Pontes. Hidrovia do Grão Pará a Mato Grosso: Projeto para Integração da Fronteira Oeste da Amazônia Colonial entre os Rios Madeira, Mamoré e Guaporé (1797-1800), Porto Velho: ABG Gráfica, 1998.

TIGRE, Paulo Bastos; PINHEIRO, Alessandro Maia (Coods.). Inovação em serviços na economia do compartilhamento. São Paulo: Saraiva educação, 2019.

TOCANTINS, Leandro. Amazônia: Natureza, Homem e Tempo Uma planificação ecológica. 2 Ed. Rio de Janeiro: Ed. Civilização brasileira, 1982.

TOMAÉL, Maria Inês (Org.). Compartilhamento da Informação. Londrina: Eduel, 2012.

TOMAÉL, Maria Inês, MARTELETO, Regina Maria (Org.). Informação e Redes Sociais: interfaces de teorias, métodos e objetos. Londrina: Eduel, 2015.

THÉRY, Hervé. Rondônia: mutações de um território federal na Amazônia brasileira. Curitiba-PR: Sk Editora, 2012.

THIRY-CHERQUES, Hermano Roberto. Pierre Bourdieu: a teoria na prática. RAP, Rio de Janeiro 40 (1): 27-55, Jan./Fev.2006. 
TRATADO DE COOPERAÇÃO AMAZÔNICA (TCA). Desenvolvimento e Conservação na Amazônia brasileira: Inventário e Análise de Projetos. American Printers. N. ${ }^{\circ} 42,1996$.

VAZ, José Carlos; RIBEIRO, Manuella Maia; MATHEUS Ricardo. Dados governamentais abertos e seus impactos sobre os conceitos e práticas de transparência no brasil. Vol. 9 , edição especial (2010) - Democracia e Interfaces Digitais para a Participação Públic.

VAZ, José Carlos. 2002. Desafios para a inclusão digital e governança eletrônica.

Disponível em: $<$ http://polis.org.br/publicacoes/desafios-para-a-inclusao-digital-e-governancaeletronica/>. Acesso em: 22/05/2019.

VERÍSSIMO, Tatiana; PEREIRA, Jakeline. A floresta habitada: história da ocupação humana na Amazônia. Belém-PA: Instituto do Homem e Meio Ambiente da Amazônia (IMAZON), 2020.

VIEIRA, Paulo Freire; WEBER, Jacques (Orgs.). Gestão de Recursos Naturais Renováveis e Desenvolvimento: Novos desafios para a pesquisa ambiental. São Paulo: Ed.Cortez, 1997.

VIEIRA, Paulo Freire. Gestão Patrimonial de Recursos Naturais: Construindo o Ecodesenvolvimento em Regiões Litorâneas. In: CAVALCANTI, Cloves (Org.).

Desenvolvimento e Natureza: estudos para uma sociedade sustentável. 2 Ed, São Paulo: Cortez, Fundação Joaquim Nabuco: Recife; 1998.

VIEIRA, Paulo Freire. (Org.). Desenvolvimento e Meio Ambiente no Brasil. A Contribuição de Ignacy Sachs. Porto Alegre: EPD, 1998.

VELHO, Otávio Guilherme. Frente de Expansão e Estrutura Agrária: Estudo do processo de Penetração numa área da Transamazônica. 3 Ed. Manaus: UEA Edições.

XIMENES, Tereza (Org.) Perspectivas do Desenvolvimento Sustentável: Uma Contribuição para a Amazônia21. Belém: Ed.NAEA/UFPa, 1997.

ZANATTA, Rafael. Cooperativismo no Brasil. IN: SCHOLZ, Trebor. Cooperativismo de plataforma: contestando a economia do compartilhamento corporativa. (Trad. Trad. ZANATTA, Rafael, A.). São Paulo: Fundação Rosa Luxemburgo; Editora Elefante; Autonomia Literária, 2016.

Zoneamento socioeconômico e ecológico de Rondônia será apresentado em reunião com integrantes da Comissão Estadual. Disponível em:

$<$ http://www.sedam.ro.gov.br/zoneamento-socioeconomico-e-ecologico-de-rondonia-seraapresentado-em-reuniao-com-integrantes-da-comissao-estadual/ >. Acesso em: 14/04/2020. 


\section{APÊNDICE - LISTA DE ENTREVISTADOS}

Avenilson Gomes da Trindade - ex-Coordenador de Desenvolvimento Agropecuário da Secretaria de Estado da Agricultura (SEAGRI) e atual Assessor Técnico da SEAGRI.

Camila Markeline da Silva - Gerente de Desenvolvimento e Políticas Públicas (GDPPSEPOG).

Claudinei Lúcio Soares dos Santos (Tijolão) - Líder do Movimento dos Trabalhadores Rurais Sem Terra de Rondônia (MST-RO).

Daniel Pereira - Ex-Vice-Governador e governador de Rondônia e atual Superintendente do Serviço Brasileiro às Micro e Pequenas Empresas (SEBRAE).

Dom Roque Paloschi - Presidente do Conselho Indigenista Missionário (CIMI) e Arcebispo da Arquidiocese de Porto Velho.

Hélio Dias de Souza - presidente da Federação da Agricultura e Pecuária do Estado de Rondônia (FAPERON) e presidente do SEBRAE-RO.

Jorge Ugalde - Gerente do Observatório (GOB-SEPOG).

Maria Petronila Neto - agente de Pastoral e Ex-coordenadora da Comissão Pastoral da Terra (CPT).

Marcelo Thomé da Silva de Almeida - Presidente da Federação das Indústrias do Estado de Rondônia (FIERO).

Natan Oliveira da Costa - Coordenador das Secretarias Executivas Regionais da Secretária de Estado de Planejamento, Orçamento e Gestão (SEPOG).

Pedro Antônio Afonso Pimentel - Secretário de Estado de Planejamento, Orçamento e Gestão (SEPOG).

Zilene Santana Silva Rabelo - Assessora da Gerência de Desenvolvimento de Políticas Públicas (GDPP-SEPOG). 